\title{
SINDH IN TRANSITION: FROM MUGHAL RULE TO BRITISH ANNEXATION, EARLY EIGHTEENTH CENTURY TO 1843
}

ESHA VERMA

A THESIS SUBMITTED TO THE VICTORIA UNIVERSITY OF WELLINGTON IN FULFILMENT OF THE REQUIREMENTS FOR THE DEGREE OF DOCTOR OF PHILOSOPHY IN HISTORY

VICTORIA UNIVERSITY OF WELLINGTON

2016 



\begin{abstract}
The eighteenth century in India saw the decline of the Mughal empire and the rise of several regional states. From the mid-1700s, however, the consolidation of regional states was checked by British expansion in the subcontinent. This thesis is a case study of one regional state, the state of Sindh in present day Pakistan. It engages in the historiographical debates about the relative importance of political and economic factors in explanations of Mughal decline during the eighteenth century. It also addresses questions about the motives that impelled British annexation, and the processes through which annexation was achieved. The study analyses Sindh's transition from being a peripheral region in the twilight days of the Mughal empire to its annexation by the British in 1843. It is based on some Persian sources, along with British archival records and a number of eighteenth and nineteenth century travelogues.
\end{abstract}

The thesis begins with a study of the process of state formation in Sindh by the Sufi Kalhora tribe. Although increasingly independent from 1701, the Sindh state continued to pay tribute to the Mughals until 1739, then to Persia until 1747, and then to the Afghan king until 1783, when the Talpur Meers replaced the Kalhoras as Sindh's ruler. Under both the Kalhoras and the Talpurs, a significant expansion of trade helped sustain the Sindh state and resulted in the emergence of a strong mercantile class. The thesis critically examines the role of the new commercial class and its relationship with Sindh's rulers.

But the political edifice constructed by the Talpurs was weak. The thesis argues that when the rise of French and Russian imperialism in the Middle East made Sindh strategically and commercially important to the British, the political weakness of the Talpur regime facilitated British encroachment in Sindh. The final annexation of Sindh in 1843, following two battles with the Meers, was the result of a number of developments: it was the culmination of a long-drawn-out weakening of the Sindhi polity; it was connected to European rivalries in Central Asia and also to the East India Company's new appreciation of the commercial importance of Sindhi trade along the Indus river. More broadly, the annexation in 1843 needs to be 
understood in the context of the interplay of British, French, Russian, Afghan, Sikh and Persian ambitions since the beginning of the nineteenth century. 


\section{Acknowledgements}

I am immensely grateful to Prof. Sekhar Bandyopadhyay for the guidance and support he has given me during the course of my $\mathrm{PhD}$ research and also to $\mathrm{Dr}$. Pauline Keating, my secondary supervisor for the support she gave me to make this $\mathrm{PhD}$ writing possible.

I am also thankful to my friends Dr. Grace Miller, Dr. Sabbaq Ahmed, Ms. Louise Mataia-Milo and Mr. Nanak Das for their co-operaction during this research. As always I am deeply grateful to my family for their continual loving support.

Finally I would like to thank the history department staff of Victoria University of Wellington for their constant encouragement. 


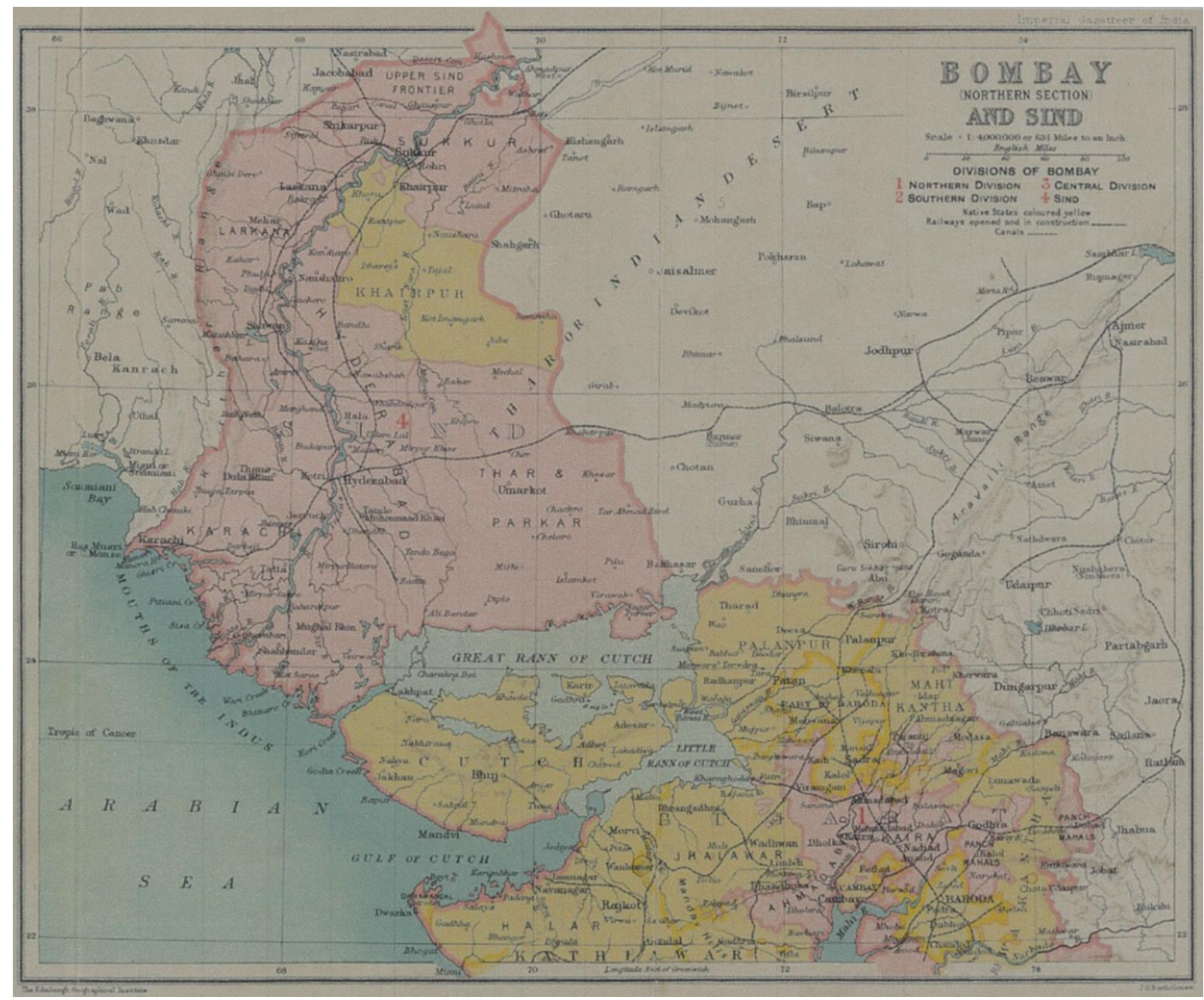

Creator: J.G. Bartholomew

Title: $\quad$ Bombay (Northern section) and Sind

Imprint: Imperial gazetteer of India. New edition, published under the authority of His Majesty's Secretary of State for India in Council. Oxford: Clarendon Press, 1907-1909.

Volume 8, opposite page 384 .

Scale: $\quad 1: 4,000,000.1$ in. to 63.1 miles.

Notes: Divisions of Bombay: 1. Northern Division, 2. Southern Division, 3. Central Division, 4. Sind. 


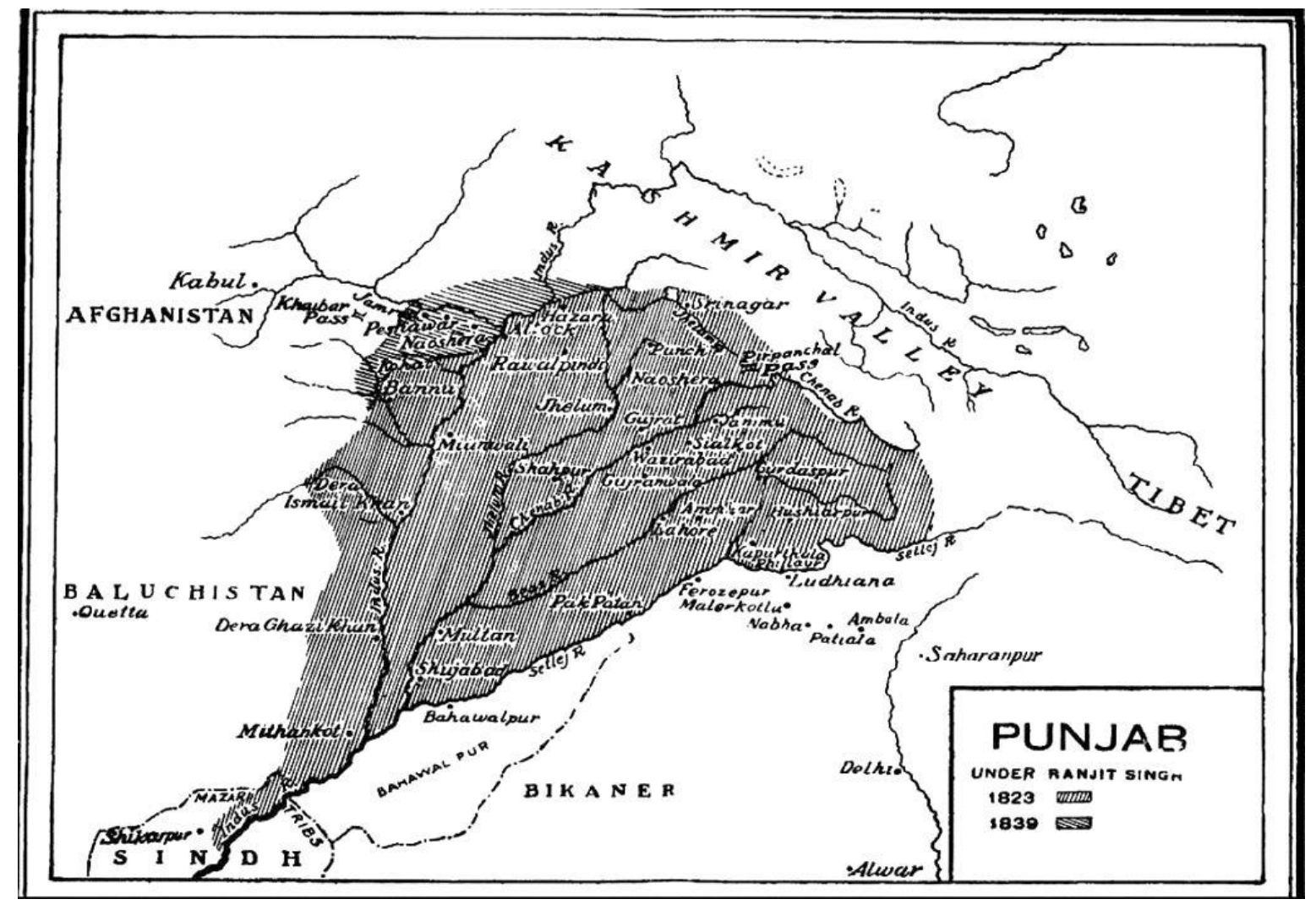

http://en.wikipedia.org/wiki/History_of the_Punjab

Gulshan Lall Chopra, The Punjab as a Sovereign State, 1799-1839 (Lahore:

Uttar Chand Kapur \& Sons, 1928), 35 


\section{Table of Contents}

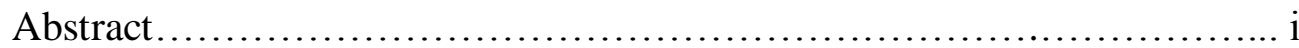

Acknowledgements....................................................

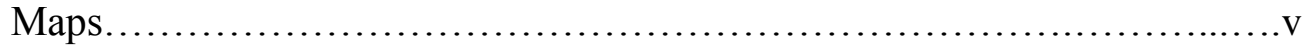

Table of Contents...................................................iv

Glossary.............................................................

Introduction.............................................................

Chapter 1: Mughal State and the rise of the Kalhoras.....................13

Chapter 2: The Kalhoras under Persian and Afghan rule.....................49

Chapter 3: Talpur Rule in Sindh....................................... 87

Chapter 4: Regional Politics and British Intervention....................113

Chapter 5: The Survey of the Indus and the Development of British

Commercial Interests in Sindh.......................................143

Chapter 6: Towards Annexation..........................................187

Conclusion.....................................................241

Appendix .......................................................253

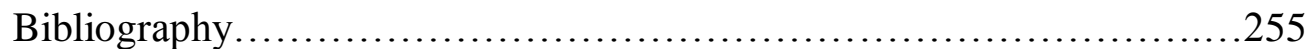




\section{Glossary}

\begin{tabular}{|c|c|}
\hline akbarnavees & news reporter/writer \\
\hline al-Mehdi & 'the divinely guided one'; 'redeemer of Islam' \\
\hline alim & 'the learned one', plural ulema \\
\hline Amaldars & officer in charge of revenue units \\
\hline Amin & $\begin{array}{l}\text { officer in revenue department with responsibility for } \\
\text { khalisa or jagir land }\end{array}$ \\
\hline amini & $\begin{array}{l}\text { remuneration given to the Amin who mediated disputes } \\
\text { between zamindars }\end{array}$ \\
\hline ana & one-sixteenth part of Rupees \\
\hline$A r b a b$ & plural of Arab \\
\hline arida & letter \\
\hline bait & abode \\
\hline Bania & $\begin{array}{l}\text { a caste which undertook commerce or trade as a } \\
\text { profession. }\end{array}$ \\
\hline batai & crop sharing \\
\hline bigha & a unit of land area which varied in different regions \\
\hline daftar & record or register \\
\hline dargah & Sufi shrine \\
\hline dera & district \\
\hline deradars & people in charge of districts \\
\hline deradari & district \\
\hline Diwan & head of revenue and justice department \\
\hline fuqra & $\begin{array}{l}\text { plural of faqir or dervish; member of a Sufi } \\
\text { community }\end{array}$ \\
\hline Faujdar & commander of a fort \\
\hline ghalla-bakshi & crop sharing \\
\hline ghuto & tax collected on profits raised by alcohol breweries \\
\hline haqiqa & a Sufi concept meaning 'truth' or 'reality' \\
\hline
\end{tabular}




\begin{tabular}{|c|c|}
\hline Haqim & chief \\
\hline hasil & tax collected \\
\hline ijara & revenue farming \\
\hline ijara colaba & tax on land watered by floods \\
\hline ijara patan & $\begin{array}{l}\text { tax on trade conducted on river banks, usually one or two } \\
\text { percent of the load's value, collected by people with } \\
\text { contracts to collect the tax on specified sections of river } \\
\text { banks }\end{array}$ \\
\hline inam & tax-exempt land grant \\
\hline insha & composition \\
\hline jagir & land given to Mughal officials in lieu of salary \\
\hline Jagirdars & holder of a jagir \\
\hline Jam & Chief \\
\hline Jat & an ethnic community \\
\hline kabail & tribe \\
\hline kam dastur & taxation rate \\
\hline karamat & miracle \\
\hline Kardars & district officers \\
\hline kankut & $\begin{array}{l}\text { estimate of grain to be collected per bigha of } \\
\text { premeasured land }\end{array}$ \\
\hline khalisa & land directly under state jurisdiction \\
\hline khanqah & hospice \\
\hline kharaj & tribute; capitation tax \\
\hline lakh & numerical unit equivalent to a hundred thousand \\
\hline laqab & title \\
\hline madad-i-ma'ash & revenue free land grant \\
\hline Madar-ul-Maham & Prime Minister \\
\hline mahal & revenue unit within a $s u b a$ or province \\
\hline Mahdawi & $\begin{array}{l}\text { an Islamic sect founded by Saiyid Muhammad Jaunpuri } \\
\text { (d.1505) based on his claim of being al-Mehdi }\end{array}$ \\
\hline
\end{tabular}




\begin{tabular}{|c|c|}
\hline mardum & common people \\
\hline Muqaddam & village headman \\
\hline mansab & $\begin{array}{l}\text { Mughal official rank which determined the status in the } \\
\text { imperial hierarchy, salary and number of cavalry to be } \\
\text { maintained by the mansabdar or mansab holder. }\end{array}$ \\
\hline Mukhtar-i-Amir & Prime Minister \\
\hline Munshi & writer, accountant \\
\hline Mutassadi & custom officer \\
\hline murid & disciple \\
\hline Naib & lieutenant or viceroy \\
\hline nazar deed & inspection \\
\hline Nizam & title of the ruler of Hyderabad in Deccan \\
\hline pargana & subdivisions within suba (province) \\
\hline parwana & order \\
\hline patta & permit \\
\hline peshkash & obligatory presents \\
\hline pir & Sufi master \\
\hline$q a z i$ & judge \\
\hline Quanungo & $\begin{array}{l}\text { an officer in a revenue department that maintained land } \\
\text { tenure records }\end{array}$ \\
\hline Rais & landed elites or chiefs \\
\hline raizki & $\begin{array}{l}\text { a goods tax; every buyer paid one ana on purchased } \\
\text { goods worth one rupee and five percent of the value of } \\
\text { purchased goods worth more than one hundred rupees; } \\
\text { Sahukars and big businessmen paid just four percent. }\end{array}$ \\
\hline Rupee & Indian currency \\
\hline Safir & envoy \\
\hline sahukar & moneylender \\
\hline Saiyid & $\begin{array}{l}\text { an individual who trace descent from Prophet } \\
\text { Muhammad's daughter Fatima. }\end{array}$ \\
\hline sajjada nashin & $\begin{array}{l}\text { one who sits on Sufi prayer carpet as successor of a } \\
\text { Sufi pir }\end{array}$ \\
\hline
\end{tabular}




\begin{tabular}{|c|c|}
\hline salak & Sufic path \\
\hline salamati kashti & $\begin{array}{l}\text { tax of six anas collected every ship or boat which } \\
\text { returned back on shore after trade }\end{array}$ \\
\hline Sanad & Royal decree or mandate \\
\hline sarai & members of Kalhora tribe \\
\hline sardarakhti & tax of one ana on every fruit tree \\
\hline sar shumari & poll tax \\
\hline sar shumari isnafigran & $\begin{array}{l}\text { a tax on woodsmiths, ironsmiths, textile dyers and } \\
\text { other labourers }\end{array}$ \\
\hline sawars & cavalry \\
\hline seri & $\begin{array}{l}\text { A unit of measuring extent of green crop on cultivated } \\
\text { land }\end{array}$ \\
\hline Shahbander & comptroller of the ports \\
\hline shaikh & Sufi saint \\
\hline shajra & chain of descent \\
\hline sharī'a & Islamic law \\
\hline shikarmari & $\begin{array}{l}\text { tax collected on fishermen which was one-third or half } \\
\text { of the value fishing }\end{array}$ \\
\hline shroff & banker \\
\hline silsila & Sufi order \\
\hline suba & Province \\
\hline Subadar & governor of suba \\
\hline suf & wool \\
\hline Sufi & $\begin{array}{l}\text { Islamic mystic or those who follow Sufism, which is a } \\
\text { school within Islam whose followers strive for direct } \\
\text { communion with god }\end{array}$ \\
\hline Sultunat & state \\
\hline taluqa & revenue unit \\
\hline tariqat & Sufic path \\
\hline Tasawwuf & Sufism \\
\hline thana & police post \\
\hline
\end{tabular}




$\begin{array}{ll}\text { Wadero } & \text { elder } \\ \text { wah } & \text { irrigation canal } \\ \text { wali } & \text { custodian, representative, friend } \\ \text { Wazir } & \text { minister, ruling elite } \\ \text { Wazir-i-Azam } & \text { Prime Minister } \\ \text { Wizarat } & \text { office of Wazir or minister } \\ \text { yarghmal } & \text { hostage } \\ \text { zabt } & \begin{array}{l}\text { revenue assessment system based on detailed } \\ \text { measurement of land }\end{array} \\ \text { zamindar } & \text { land holder who claims his share of produce from land } \\ \text { zardarakhti } & \begin{array}{l}\text { tax on harvested fruit at the rate of one-third or half of } \\ \text { the value of the total amount of fruit harvested } \\ \text { district or revenue unit within a suba } \\ \text { nila }\end{array}\end{array}$




\section{Introduction}

The eighteenth century saw the decline of the Mughals in India. Their empire fragmented into several autonomous regional states, and Mughal power became confined to the Delhi region. Some of the regional states such as Awadh, Hyderabad and Bengal were formed by the former Mughal nobles or their protégés. The Sikh, Maratha and Satnami states were established by peasant rebels led by local people. New states such as Rohilkhand and Farrukhabad emerged in regions that had been 'Mughal' in name only. Similiarily the Malabar and Mysore regions, where new polities also emerged in the 1700s, Mughal influence had always been weak. The Mughals lost the province of Sindh to Persia following Nadir Shah's invasion in 1739.

The emergence of regional states in the eighteenth century was halted by British expansion in India. ${ }^{1}$ From the middle of the century, the English East India Company [EIC] became a significant player in the interregional political conflicts of the time. Victories in the Battles of Plassey (1757) and Buxar (1767) against the Nawabs of Bengal and Awadh gave the EIC access to resources that enhanced its Asian trade. Immediately after the Buxar victory, the British army, together with a contingent of merchants and gumastahs (middlemen), moved to Awadh. The granting of a parwana (permit) by the Mughal Emperor to trade freely in Bengal, and the EIC's illegal trade in Awadh, led to clashes with the Nawabs of Bengal and Awadh. In 1775 the Nawab of Awadh lost Benaras to the EIC, and Awadh state finances were undermined by 'subsidies' paid to the British and by the Company's 'illegal extortions'. ${ }^{2}$ The Fourth Anglo-Mysore war (1799), the third Anglo-Maratha war (1817-18) and the second Anglo-Sikh war (1849) were decisive in the establishment of British rule in India. The annexation of Sindh in 1843 and of Awadh in 1856 completed the process of Britain's annexation of India.

Rudrangshu Mukherjee, 'Trade and Empire in Awadh 1765-1804', Past \& Present, no. 94 (Feb., 1982), 102.

Ibid, 101. 
This thesis offers a history of the region of Sindh, in present day Pakistan, during the century or so before it was annexed by Britain in 1843. It is a complex history. Before we begin, we need to examine the historiography related to the history of Sindh and its near neighbours as well as the history of British expansion in northwest India.

\section{Review of Historiography}

This study takes a space overlapping two sets of historical literature - one on the decline of the Mughal empire and the other on the rise of the British. Different scholars provide different reasons for the collapse of the Mughal empire and the emergence of 'successor states'. There are also disagreements about the impact that the fragmentation of the empire had on the economy of eighteenth century India. Scholars' views are shaped by their understanding of the nature of the Mughal state and its role in the economy and society. Those who assume that the Mughal state was highly centralised judge the eighteenth century to be a period of economic decline, even a 'dark age'. On the other hand, those who consider the Mughal state to be weak, a mere 'paper tiger', believe that its decline and collapse had little or no effect on the political systems and economies of much of the subcontinent.

Marxist historians such as Irfan Habib, M.Athar Ali, Satish Chandra and Shireen Moosvi find the Mughal state to be a strongly centralised state; they point to the effective functioning of the state's 'systemic' structures, namely the jagirdari and mansabdari systems. ${ }^{3}$ Habib's is the first analysis of Mughal decline that examines state institutions. He points to the exploitative taxation system that squeezed agriculture by means of the efficient collection of excessively high taxes. The revenue that the Mughals extracted from the peasants was shared with the zamindars, the class of exploitative intermediaries possessing hereditary rights to

3 Irfan Habib, The Agrarian System of Mughal India (Bombay: Asia Publishing House, 1963); Satish Chandra, Parties and Politics at the Mughal Court, 1707-1740, $2^{\text {nd }}$ ed. (New Delhi: People's Publishing House, 1969); M. Athar Ali, 'Recent Theories of Eighteenth-century India' in P.J. Marshal ed. The Eighteenth Century in Indian History: Evolution or Revolution? (Delhi: Oxford University Press, 2003); Shireen Moosvi, People, Taxation and Trade in Mughal India (New Delhi: Oxford University Press, 2008). 
collect land taxes. In the Marxists' view, the state was both an 'instrument of exploitation' and the protector of exploiters such as the zamindars. That the tax system over-burdened the peasants is evidenced in the numerous peasant revolts of the seventeenth and eighteenth centuries; zamindars, because they were leaders of rural communities, sided with the peasants. For Habib, the rebellions constituted an agrarian crisis that was the consequence of flaws in the structure of the Mughal state; the flaws caused it to fall apart in the eighteenth century and make room for the rise of new states. ${ }^{4}$

The Mughal state was parasitic in relation to the agrarian sector, denying it resources for development, at the same time as stimulating the growth of merchant capitalism in urban centres. Merchant capital, however, did not develop into industrial capital in India under the Mughals because there was no market for industrial products in the countryside. In urban areas the Mughal ruling class's purchasing power sustained urban markets. From the 1700s, 'agrarian crises' were drying up the flow of rural surplus to the urban sector, and this stymied urban commerce. As Delhi began losing control of regions within its far-flung empire, the flow of cash to the centre was further attenuated and so, therefore, was the state's ability to mobilise capital in favour of commerce. Capitalism could not develop in India under the Mughals, so it could not prevent economic decline as the state centre weakened. ${ }^{5}$ To demonstrate economic decline in the eighteenth century, Habib uses revenue figures, prices, interest rates, agricultural output and population data from various regions. His views have been supported by other historians belonging to or associated with the Aligarh school. ${ }^{6}$

Different arguments are posited by revisionist historians such as Christopher Bayly, Muzaffar Alam, Sanjay Subrahmanyam, Frank Perlin and others. They have analysed the economic history of pre-colonial India and challenge the Marxist

Habib, The Agrarian System of Mughal India, 364-405.

ibid.

Ali, 'Recent Theories of Eighteen century India', Moosvi, People Taxation and Trade, Chandra, Parties and Politics, Iqtidar Alam Khan. Gunpowder and Firearms: Warfare in Medieval India. (New York: Oxford University Press. 2004). 
historians with the argument that the eighteenth century in India was a period of economic and political reconfiguration rather than decline. ${ }^{7}$ While some regions saw political disorder, some experienced 'new cycles of growth and regeneration'. 8 Bayly believed that political authority did not decline but instead was diffused and relocated to new regional states. ${ }^{9}$ The new states created favourable conditions for economic growth in the regions. Economic prosperity, not decline, led to the strengthening of regional polities and the consequent downfall of the Mughal empire.

Among the best studies of the roles of merchants and bankers in the making of a vibrant economy in eighteenth century India are those by Philip C. Calkins, M.N. Pearson, Karen Leonard, Das Gupta and Bayly. ${ }^{10}$ These historians have examined the political roles played by the commercial classes and how their support shifted from the central Mughal state to regional rulers. Bayly and Alam claim that merchants and moneylenders who grew wealthy under the Mughals actually helped

C.A.Bayly, Rulers, Townsmen and Bazaars: North Indian Society in the Age of British Expansion, 1770-1870 (Cambridge: Cambridge University Press, 1983); Muzaffar Alam and Sanjay Subrahmanyam (eds.), The Mughal State: 1526-1750 (Delhi, Oxford University press, 1998); David Washbrook, 'Progress and Problems: South Asian Economic and Social History c.1720-1860', Modern Asian Studies, V. 22, No.1, February, 1988, 63-64 in Binay Bhushan Chaudhuri, Peasant History of Late Pre-Colonial and Colonial India, History of Science, Philosophy and Culture in Indian Civilization, Vol.VIII, Part - 2 (New Delhi: Pearson Education India,2008); Frank Perlin, 'Of White Whale and Countrymen in the Eighteenth Century Maratha Deccan: Extended Class Relations, Rights, and the Problem of Rural Autonomy Under the Old Regime,' Journal of Peasant Studies, V. 2, no. 2, 1978, 172237; Ashin Das Gupta, Malabar in Asian Trade, 1740-1800 (New York: Cambridge University Press, 1967); André Wink, Land and Sovereignty in India: Agrarian Society and Politics under the Eighteenth Century Maratha Swarajya (New York: Cambridge University Press, 1986); Om Prakash, Bullion for Goods: European and Indian Merchants in the Indian Ocean Trade, 1500-1800 (Delhi: Manohar, 2004); Karen Leonard, 'The "Great Firm" Theory of the Decline of the Mughal Empire', Comparative Studies in Society and History, Vol. 21, no.2, April 1979, 151-167; Seema Alavi, The Eighteenth Century in India ( New Delhi: OUP, 2002).

C.A.Bayly, Rulers, Townsmen and Bazaars.

Ibid.

Philip C Calkins, "The Formation of a Regionally Oriented Ruling Group in Bengal'," Journal of Asian Studies, XXIX (August 1970).B. B. Chaudhuri, Peasant History of Late Pre-Colonial and Colonial India (New Delhi: Pearson Education India, 2008); M.N. Pearson, "Political Participation in Mughal India'," Indian Economic and Social History Review, Vol. IX (June 1972). Leonard, 'The "Great Firm” Theory'; Ashin Das Gupta, Indian Merchants and the Decline of Surat: c. 1700-1750 (Wiesbaden: Franz Steiner Verlag, 1979); Bayly, Rulers, Townsmen and Bazaars. 
lay the economic foundations of the new regional states. ${ }^{11}$ Bayly and Subrahmanyam point out that the new merchant class, the 'portfolio capitalists', acted as intermediaries between the British and regional rulers and eventually allied with the EIC, facilitating its rise to power in India. ${ }^{12}$

The 'decline thesis' has been countered by scholars who examine revenue figures for the Awadh, Benaras, Muradabad and Bareily regions. Muzaffar Alam shows that revenue in these places rose in the eighteenth century and he suggests that this indicates growth in the agrarian sector; ${ }^{13}$ he does not, however, address Habib's point that prices rose in the same period. ${ }^{14}$ Alam argues that the increase in rebellions involving peasants and zamindars are also evidence of economic vibrancy in rural India. The rebellions did not link up to form a mass movement against the Mughals because they were rooted in local loyalties and divided by class and caste. ${ }^{15}$

Revisionist historians usually start with the premise that the Mughal state was never tightly centralised and its authority was exercised unevenly across regions within the empire. Alam and Subramnyam, for example, contend that the efficient collection of land taxes, the rates of which were specified by the Mughals' zabti system, occurred in only two-thirds of the empire. ${ }^{16}$ In the nasq areas the Mughal control was weaker than in the zabt areas. Even in the zabti provinces, the system was not rigorously enforced everywhere. Washbrook argues that the Mughals' taxation system largely served a symbolic function; it was a symbol of sovereignty and a means of binding communities to the empire; the idea of a centralised state was just that - an idea and an illusion. The ruler in Delhi and autonomous

C.A.Bayly, Rulers, Townsmen and Bazaars, passim; Muzaffar Alam, The Crisis of Empire in Mughal North India: Awadh and the Punjab (1707-1748) (Delhi: OUP, 1997), 40. S. Subrahmanyam, and C.A. Bayly, 'Portfolio Capitalist and the Political Economy of Early Modern India', Indian Economic and Social History Review, V. 25, no. 4, 1988, 401-424.

13 Irfan Habib, 'The Eighteenth Century in Indian Economic History' in P.J.Marshal (ed.), The Eighteenth Century in Indian History: Evolution or Revolution? (Delhi: OUP, 2003), 106.

14 Muzaffar Alam, 'Aspects of Agrarian Uprisings in North India in the Early Eighteenth Century' in Muzaffar Alam and Sanjay Subrahmanyam (eds.),The Mughal State: 1526-1750 (Delhi: OUP, 1998), 467.

15 Muzaffar Alam, 'Aspects of Agrarian Uprisings'.

16 Muzaffar Alam and Sanjay Subrahmanyam, 'Introduction' in Muzaffar Alam and Sanjay Subrahmanyam (eds.), The Mughal State, 15-16. 
communities in the localities constituted two interrelated realms of authority in the Mughal empire. ${ }^{17}$

A recent trend in scholarship on the Mughal period is to differentiate between core and periphery when assessing Mughal power. Farhat Hasan has studied the Mughal state's methods of ideological control and shows how local institutions were powerful enough to negotiate with the state. ${ }^{18}$ The Mughal state, he says, was 'dualistic' in nature, because it shared power with the local gentry, social groups and powerful local people such as wealthy merchants. So at the local level, power was exercised not only by the state but also by local elites. And the state centre and local power brokers worked in tandem to the extent that power exercised in the periphery appeared to emanate from the centre. The symbols of authority and material resources were shared by elites in the localities and elites at the centre, engendering some competition. The competition between core and periphery resulted in what Hasan calls a 'dynamic' instability in the political structure of the state. Because power was negotiable between the core and the periphery, the Mughal's power was far from absolute. To prove his point, Hasan shows that the Mughal state, in its dealings with powerful corporate bodies in the localities and with zimmis (nonMuslims), could not insist on strict adherance to the shariat (Islamic law) and had to make compromises.

The shariat, however, was usually applied flexibly; it had the capacity to accommodate local traditions. At the same time as requiring obedience to sharia, the Mughal regime at local levels incorporated local traditions. So what Farhat Hasan sees as the centre's compromises with local power was in fact the assimilation of local traditions by the state. The local power that the state had to accommodate was the power of zamindars and village headmen. The political authority claimed by these people was rooted in local traditions and cults; the same traditions and cults, however, did not give them authority as military leaders. The state, in

\footnotetext{
17 Washbrook, 'Progress and Problems', 63-64.

18 Farhat Hasan, State and Locality in Mughal India: Power Relations in Western India c 15721730 (New York: Cambridge, 2004).
} 
accommodating 'the local', was never willing to compromise with challengers to its authority; whenever there was armed resistance, it was crushed.

The scholarship on Mughal India raises a number of important questions that have not been addressed in studies of Sindh. Sarah Ansari's 1992 book is about the Sindh pirs, but only one chapter deals with the pre-colonial period; the other five focus on the 1843 - 1947 period. ${ }^{19}$ We have, therefore, no substantial work on Sindh in the 1700 s and early 1800 s. My thesis is a case study of one of India's peripheral regions in the period when the Mughal empire was shrinking and becoming weak, and asks a number of questions. Was Mughal state control weak in Sindh in the early eighteenth century? Did the Mughal state have to compromise with powerful local elites in Sindh to get taxes collected and to maintain peace and order? What role did the mercantile classes play in pre-colonial Sindh? Did Persian and Afghan rule bring significant changes to Sindh from 1739? My study of Sindh from the early 1700s to 1843 will, therefore, fill a major gap in the historiography of eighteenth century India.

Very few histories of British expansion in India give much attention to Sindh, but analyses of what happened elsewhere, and especially in north-west India, are highly pertinent to my study. Michael Fisher has shown how, after 1767, adroit interventions in local politics by EIC agents progressively built Company power in Awadh, part of the process was winning the trust of members of the royal court of Awadh and making them dependent on the Company's favour. This explains why the region's eventual takeover by Britain in 1856 was smooth and peaceful. Company Residents in other parts of India, including Delhi, built British power in those places in much the same way. ${ }^{20}$

The emergence of a new social class in eighteenth century India, the class of rich merchants, has been identified by a number of historians as critical for an understanding of the creation of British India. According to Bayly, rich merchants 
became agents of British imperialism and collaborated with the Company in its conquest of India. ${ }^{21}$ Bayly points out that Bengal province, commercial communities and the new gentry had all 'revolted against or surreptitiously withdrew from under the Mughal umbrella' in the eighteenth century; the same areas and groups 'became the foundation of the British colonial regime. ${ }^{22}$

The important role played by indigenous actors in the establishment of Company rule in India has been emphasised by Lakshmi Subramanian. She says that the Company's success in Surat in 1759, the seizure of Surat Castle that began the transfer of authority from the old ruling elite to the Company, should be attributed to the support the Company received from the Bania trading community. ${ }^{23}$ The AngloBania alliance worked for both parties. The Company served the Banias by reversing the damage done to commerce by Mughal decline in the eighteenth century. And financial assistance from the Bania community helped the Company win the AngloMaratha wars and establish its hegemony in many parts of Gujarat and the Deccan. By presenting itself as the 'protector' of 'fair-traders', the Company was able to solicit financial contributions from the indigenous trading and banking communities in Bombay, Benaras and Hyderabad; those contributions helped the Company expand its power in India. ${ }^{24}$

There is now broad agreement on a point made by Rudrangshu Mukherjee, that British expansion in India was driven by both political and economic imperatives after the 1780s. But Mukherjee looks well beyond local factors when explaining the rise of British power. ${ }^{25} \mathrm{He}$ argues that it was the Industrial Revolution in Britain that impelled British expansion in India. ${ }^{26}$ The 'logic of absorbing Awadh', he says, "was to incorporate it into the capitalist system... [as] one of the many links

21 C.A. Bayly, Indian Society and the Making of the British Empire, $2^{\text {nd }}$ ed. (Cambridge: Cambridge University Press, 1990), 5.

22 Ibid., 11.

23 Lakshmi Subramanian, 'Bania and the British: The Role of Indigenous Credit in the Process of Imperial Expansion in Western India in the Second Half of the Eighteenth Century', Modern Asian Studies, Vol. 21, no.3, 1987, 473-510.

$24 \quad$ Ibid, 510.

25 Rudrangshu Mukherjee, 'Trade and Empire in Awadh', 85-102.

26 Ibid., 94. 
in the chain of capitalist expansion and the creation of colonial hinterlands and the maintenance of imperial markets and trade.' Mukherjee's argument has been challenged by scholars such as P.J. Marshall, J.R. Ward, P.J. Cain and A.G. Hopkins. ${ }^{27}$ Marshall points out that even after 1801, when the EIC made its first military advance in Awadh, the Company still supplied piece-goods to European markets, not just raw materials for British industries. ${ }^{28}$ In any case, Marshall says, Wellesley's concerns were political more than economic; he annexed Awadh because he wanted to 'overpower the Maratha confederacy' and to rule the whole of India. $^{29}$

Marshall also disagrees with Mukherjee's inference that metropolitan authorities directed and managed British imperialism in India. 'The British won power as participants in the Indian political struggle', he argues. ${ }^{30}$ It was developments in the eighteenth century in India that gave the British opportunities to intervene in Indian politics and annex parts of India. In other words, the process of British expansion in India was guided by Indian conditions, on 'Indian terms'. ${ }^{31}$ The 'sub-imperialism' of the men on the spot rather than metropolitan interests built British power in India. ${ }^{32}$ The 'men actually in India' did the groundwork at local levels that ensured the success of British interventions in different parts of India. ${ }^{33}$

Even so, Marshall does not deny the importance of the British government's 'national commitment to empire', nor the role of trade in imperial expansion. ${ }^{34}$ The

P.J. Marshall, 'Early British Imperialism in India', Past and Present, no. 106, Feb 1985, 165., J.R. Ward, 'The Industrial Revolution and British Imperialism, 1750-1850', The Economic History Review, New Series, Vol. XLVII, no. 1, Feb 1994, 44-65, P.J. Cain and A.G. Hopkins, 'Prospective: Aristocracy, Finance and Empire, 1688-1850', in P.J. Marshall ed. The Eighteenth Century in Indian History: Evolution or Revolution? (New Delhi: OUP, 2003), 392

28 Marshall, 'Early British imperialism in India', 165.

29 Ibid., 169. P.J. Marshall, 'The British in Asia: Trade to Dominion, 1700-1765' in P. J. Marshall ed. The Oxford History of the British Empire: The Eighteenth Century (Oxford : Oxford University Press, 1998), 497.

$31 \quad$ Ibid, 506.

Ibid, 494. Ibid, 499. P.J. Marshall, 'Introduction' in P.J. Marshall ed. The Oxford History of the British Empire, 26. 
Indian trade was regarded as 'national trade' in Britain because it had become embedded in Britain's system of public credit; losing India to France could result in national bankruptcy. France was a real threat because the revolutionary and Napoleonic wars had spilled over European borders, threatening British possessions in South Asia, and making the defence of India a major concern in Britain. Wars among European powers, therefore, gave impetus to the expansion of the British power in India. ${ }^{35}$

Cain and Hopkins argue that it was not the Industrial Revolution but the financial revolution in the 1690s in Britain that generated 'expansionist forces' and, therefore, Britain's overseas expansion. The British move into India resulted in a clash of the 'military-fiscal organisations' of the Mughals and their successor states with the EIC; the two organisations competed for access to tax revenue and, therefore, political power. ${ }^{36}$ The British were winners of the Mughal-EIC tussle because it was supported by the local mercantile class. ${ }^{37}$ In relation to Sindh and the Punjab, Cain and Hopkins argue that British expansion into these two regions in the 1840s was driven by the Company's financial troubles; these troubles were seriously exacerbated by the abolition in 1813 of the EIC monopoly of trade in India and, in 1833 , its monopoly of the China trade. ${ }^{38}$

\section{The thesis}

The annexation of Sindh, one of the last British conquests in India, has been studied by P.N.Khera and R.A.Huttenback. In June 1807 Napoleon signed the treaty of Tilsit with Russia and prepared to invade India. After Napoleon's defeat in 1815 there was a fear that Russian forces might march through Afghanistan and attack Sindh. According to Khera and Huttenback, the perceived French and Russian threats to

\footnotetext{
$35 \quad$ Ibid, 26.

36 P.J. Cain and A.G. Hopkins, 'Prospective: Aristocracy, Finance and Empire, 1688-1850', in P.J. Marshall ed. The Eighteenth Century in Indian History: Evolution or Revolution? (New Delhi: OUP, 2003), 392.

$37 \quad$ Ibid.

38 P. J. Cain and Antony G. Hopkins, British Imperialism: 1688-2000, $3^{\text {rd }}$ ed. (New York: Routledge, 2013), 282.
} 
British India, was the reason why the British annexed Sindh in $1843 .{ }^{39}$ My thesis assesses the validity of this argument in the light of the recent debates about British empire-building in India discussed above, and through an analysis of primary sources related to the history of Sindh in the century before 1843. The thesis asks whether the British interest in Sindh resulted from international pressures such as French and Russian imperialism in the nineteenth century and the consequent need to protect India's north-west frontier, or whether ambitious Governors-General and their subordinates judged Sindh to be a commercially and politically important 'prize' worth winning for Britain. The thesis will also consider the ways in which Sindh's domestic politics, the state's political structures and the support of Sindh's mercantile class might have contributed to British success in Sindh.

The thesis consists of six chapters. Chapter one introduces the Kalhoras, a tribe that, under the leadership of pirs (Sufi masters), had moved from pastoralism to putting down sedentary roots in the Sindh region; the chapter examines the process of state formation by the Kalhoras in Sindh in the early eighteenth century. The second chapter traces Sindh's transition from a territory under Mughal rule to a tributary state within the Persian empire (from 1739) and then within the Afghan empire (from 1747). The tribute that Sindh was required to pay to the Afghan ruler was a significant drain on Sindh's wealth during the later phase of Kalhoran rule, a time when internal conflict over succession was debilitating the regime. Chapter three documents the decline of the Kalhoran rule and its overthrow by its erstwhile disciples (murids), people from the Baluch tribe of Talpurs; the Baluchis had been drawn into the Kalhoran polity to constitute the Sindh army. Why Sindh became important for the British in the early nineteenth century is the focus of Chapter 4. Lord Wellesley used alarm over French expansion under Napoleon and the threat to the security of British India posed by Afghan ruler Shah Zaman as pretexts for extending British influence into Central Asia; the route from British India to Central Asia was through Sindh. Chapter five tracks the growing British involvement in 
Sindh from the late 1820 s and the strenuous efforts made to open the Indus river to British trade. The role played by the Sindhi merchants in enabling the British to get a firm commercial foothold in Sindh is also examined. Chapter six discusses the political implications of Lord Auckland's decision to restore the deposed ruler of Afghanistan, Shah Shuja ul Mulk, to the Afghan throne, ensuring that he act as a British puppet. We explore the connection between the subsequent Anglo-Afghan war and the annexation of Sindh in 1843. The roles played by Governor-General Lord Ellenborough and the British military commander in Sindh, Charles Napier, are also examined.

\section{Sources}

This study is based on Persian and English language sources. The Persian sources used are: Jamm-i-Badi, which is a collection of documents assembled by Jan Muhammad Munshi around 1733. Manshur-ul Wasiyat wa Dasturul Hukumat, which is a will written by Noor Muhammad Kalhora; Tuhfat-ul-Kiram written by Meer Ali Sher Qani Thattvi, a contemporary of the Kalhora rulers; Mirat-i-DaulatAbbasia compiled by Lala Daulat Rai around 1800; Jawahir-i-Abbasia by Shaikh Mohammad Aazam, compiled between 1809 and 1830. Sources such as treaties and agreements between the Meers of Sindh and the EIC have also been used. We have available to us numerous nineteenth century publications such as official reports, travelogues and memoirs of British officials who were sent to Sindh; the study has used the writings of James McMurdo, Charles Masson, James Jacob and James Outram. The official dispatches of the EIC when it was acting under the Board of Control from 1784 are preserved in the Maharashtra State Archives. Dispatches relating to Sindh from the Court of Directors and the Secret Committee to the Bombay Presidency as well as the Bombay Political Department records are also preserved in the Maharashtra State Archives. The study has used these Bombay archival sources and several sources at the National Archives of India. It has also used a range of secondary sources published in English, Urdu and Sindhi. 


\section{Chapter 1}

\section{Mughal State and the rise of the Kalhoras}

Sindh was annexed by the Mughal Emperor Akbar (1542-1605) in 1595 and remained a part of the Mughal empire until the middle of the eighteenth century. However it was a peripheral province and the issue of its level of integration into the empire is relevant to the debate in the Indian historiography about whether the Mughal state was a centralised state or not. ${ }^{1}$ During the middle of the eighteenth century Sindh passed into the hands of a locally powerful religious and tribal group called the Kalhoras. The Kalhora rulers however, still drew their political legitimacy from the Mughals until Nadir Shah's invasion of India in 1739, when Sindh became a part of the Persian Empire. After Ahmed Shah Abdali's invasion of India in 1748 it became a part of the Afghan Durrani empire and remained so until it was annexed by the British in 1843.

However being a peripheral state implied that Sindh's local administration was little affected and controlled by the centre, which itself was in flux throughout the eighteenth century. Sindh on many occasions throughout its history had witnessed attempted state formations on ethnic, tribal or sectarian lines. Due to its geographical location it saw constant influxes of people from central Asia. The various tribes that settled in Sindh had autonomous tendencies which on many occasions made them defy the established state. The various tribes of Sindh also competed with each other over the control of land and resources. ${ }^{2}$ The establishment of an autonomous state by the Kalhoras is remarkable in the history of Sindh for it was a state formed by a local Sindhi dynasty of religious mendicants and represented a struggle against Mughal imperialism.

In this chapter I will examine the process of state formation by the Kalhora leaders and how events in India in the eighteenth century affected its progress. This

Muzaffar Alam and Sanjay Subrahmanyam, The Mughal State 1526-1750 (New Delhi: Oxford University Press, 2001), 1-71.

2 Mirza Kalich FredunBeg, A History of Sindh, V. II, $2^{\text {nd }}$ ed., (Karachi: Scinde Classic, 1982). 
will contribute to the debate on eighteenth century India which mainly revolves around two issues - whether the Mughal state was a centralised one or not, and whether its decline in the eighteenth century indicates an economic crisis throughout the region it controlled. I will then introduce the history of the Kalhoras, their attempted state formation and the various stages it passed through.

\section{The nature of the Mughal state in Sindh}

Herbert S. Lewis has expressed his concern about the difficulties scholars face when studying state formation given the large volume of data we have from different parts of the world; the great variety of states make it hard to formulate a general theory of the process of state building. ${ }^{3}$ Ina E. Slamet-Velsink, in her study of the formation of the Indonesian state uses an interdisciplinary approach, combining the methods of 'cultural anthropology' and 'prehistoric research'. She says that 'social differentiation', 'stratification' and 'hierarchization' precede the emergence of a state. ${ }^{4}$ This observation is relevant when studying the history of state formation in pre-modern India between 1000 and 1700 - when there emerged two great empires the Delhi Sultunat and the Mughals. Associated with the rise of imperial power was the process of state formation in various tribal hinterlands of the country at various stages of the pre-modern period. The issue of state formation in India has given rise to a lot of controversy among scholars, and all of the debates are related to the nature of the Mughal state and the extent of its control over peripheral areas, such as Sindh, where local polities enjoyed considerable autonomy. ${ }^{5}$

For the Mughal Sindh in the eighteenth century we have very few primary sources. One of the few is Jamm-i-Badi, a collection of documents from the 17031734 period, compiled by Jan Muhammad Munshi (b. Muhammad Arif), in which

Herbert S. Lewis 'Warfare and the Origin of the State: Another Formulation' in Henri J.M.Claessen and Peter Skalnik ed. The Study of the State, $2^{\text {nd }}$ ed. ( The Netherlands: Mouton Publishers, 1981), 20.

$4 \quad$ Ina E. Slamet- Velsink, Emerging Hierarchies: Process of Stratification and Early State Formation in the Indonesioan Archipelago: Prehistory and the Ethnographic Present. (Leiden: KITLV Press, 1995), 279.

5 Herman Kulke 'Introduction: The Study of the State in Pre- Modern India' in Herman Kulke ed. The State in India: 1000-1700', (New Delhi: Oxford University Press, 1993), 1. 
we can find clues about the nature of the Mughal state. One document mentions that in the khalisa (state owned) land a Mughal diwan, who was posted to Bhakkar from Agra during the time of governorship of Prince Mu'izz al-Din in Multan (which was a part of Mughal Sindh), reduced agricultural taxation rates ( kam-dastur) for the peasants to encourage them to produce bigger surplus and thereby increase government revenue. ${ }^{6}$ Another Jam-i-Badi document mentions confirmation of grants of madad-i-ma'ash (revenue free land grant) land in Siwistan by Nizamul Mulk Bahadur Fateh Jang, the wazir of Muhammad Shah to Shaikh Muhammad Warris in 1724. This land was first granted to him by Shah Alam in $1709 .^{7}$ These examples show that Mughal rule was entrenched in places in Sindh such as Bhakkar.

That the Mughal state was trying to exert central control over Sindh could also be seen in frequent mention of the authoritative position of the Mughal Governors in Sindh until the middle of the eighteenth century. The Mughal rule was however not entrenched everywhere in Sindh as there still remained tribal pockets inaccessible to the state and from where, therefore, they could not extract any revenue. Mazahar-i-Shahjahani (prominent ruling elites or nobles) a seventeenth century source written during the reign of Shah Jahan (1628-1658) by Yusuf Mirak (d. 1634) mentions many tribes and tribal areas that were recalcitrant. In the region of Sihwan, for example, tribes such as the Korejah, the Shaykh, and the Panhwar were regular in paying revenues, but the tribes of Samejah Unar and Samejah Bukyah paid only a part of the revenue and payments were irregular. Collecting revenue from certain tribes was always difficult for the Mughal jagirdars. ${ }^{8}$

Sometimes jagirdars had to seek help from the submissive peasant tribes such as Pahawar and Korejah in the parganah (province) of Sihwan to collect revenue from the recalcitrant peasants. In pargana Khittah of Sihwan region jagirdar Rai Singh had to defeat Samejah Dahiri tribe in a battle to make them accept his

6 Jan Muhammad Munshi b. Muhammad Arif, Jam-i-Badi, folio 35a-38a, Ms. Aligarh Muslim University. Arif, Jam-i-Badi. Muhammad Saleem Akhtar' Sindh Under the Mughals: An Introduction to, translation of and Commentary on the Mazahar-i-Shahjahani of Yusuf Mirak, (Islamabad: National Institute of Historical and Cultural Research, 1990), 170. 
overlordship and pay revenue. ${ }^{9}$ In parganah Lakut the tribe of Samejah Unar appropriated the land of Lakah tribe and the Mughal jagirdar there could not check them. The pargana Lakut was therefore deleted from the revenue roll. The rest of the peasants also sided with the Samejah Unar and cultivated the land of this tribe. ${ }^{10}$

Therefore, for effective administration in a region like Sindh, where closeknit tribal communities existed, it was imperative to maintain strong police posts or thanas and also to ensure that the peasants were strong enough to resist any tribal attack that could result in the disruption of the revenue system and desertion of the entire village. Since that surveillance and control were not possible, the jagirdars had to come to compromises with the peasants. During the reign of the Mughal ruler Shah Jahan (1628-1658), Bakhtiyar Beg, the jagirdar of Sehwan collected revenue according to crop-sharing, which was a fairer system than the zabt, followed previously. In a crop sharing arrangement, the lands of arbabs, muqaddams or qunangos (land holders) were also assessed along with those of the peasants, while in the zabt system muqaddam (Village headman) and qunnango (officer who deals with land tenure and revenue department) assessed revenue only on peasant land and collected their share of assessed revenue from them. ${ }^{11}$

The Mughal administration also had to continually negotiate with turbulent tribal groups like the Nahmardis, a closed tribal community which moved from one place to another and seldom made agriculture their occupation. They engaged in raiding and plundering and they called the place they lived in a thanas. No Mughal jagirdar or subhdar ever disturbed or attacked their thanas. ${ }^{12}$ During the eighteenth century tribal rebellions by such groups increased in Sindh and the Mughal governors had to rely on the locally powerful Kalhora tribe for collection of revenue by subduing these other turbulent peripatetic tribes.

Questions however remain about the exact origin of the Kalhoras, and the chronological accuracy of the various events mentioned in the medieval sources

Ibid., 171.

Ibid., 177.

Ibid., 181.

Ibid., 200. 
relating to their rise in power. While the Kalhoras themselves claimed an Arab descent and lineage going back to Hazrat Abbas, the Prophet's uncle, their early history, recorded in the much later sources says that they were Sindhis or Sindhised Arabs. Their descent from Hazrat Abbas and their Arab origin have been questioned by many on ethnic and social grounds. The British ethnographer H.A. Rose says that the Kalhoras were a Jat tribe of Sindh. ${ }^{13}$ Richard Burton, a British officer who visited Sindh in the nineteenth century thought that the Kalhoras were from the Sindhi Chana tribe and were Hindus who converted to Islam later. ${ }^{14}$

It is possible that on ethnic grounds, the Kalhoras seemed like local Sindhis to Burton, but we do not know how he could say that they were from the Sindhi tribe of Chanas. ${ }^{15}$ If their early history as recorded in the eighteenth century Persian sources is to be trusted, they were Arabs who came to Sindh through Makran. ${ }^{16}$ They married local Sindhi women from the families of local chiefs from the Abra and Samma tribes, which added to their political significance and could have also contributed in making them appear more Sindhi than Arab over the period of centuries. Gradually, within the context of the turbulent and fragmented nature of tribal polities in Sindh there arose a mutually beneficial relationship of dependence and reliance between the Mughal state, which nominally exerted sovereign power over the region, and the locally powerful Kalhora tribe. However, this situation also raises questions on the nature of society that evolved in Sindh over the centuries after its annexation by the Umayyads in 711 and also the usefulness of concepts such as 'tribe' and 'ethnicity' which emerged in the discourses of the eighteenth-nineteenth centuries. In the following section of this chapter, the concept of tribe will be examined and assessed for its usefulness in the context of Sindh. Province, V.2, rev. ed. (Delhi: Low Price publications, 1999), 440.

14 Richard F. Burton, Sindh and the Races that Inhabit the Valley of the Indus: with Notices of the Topography and History of the Province, rev. ed., (New Delhi: Asian Educational Services, 1999), 410.

15 Ibid., 410

16 Ali Sher Qani Thattvi, Tuhfat-ul-Kiram, Urdu ed. (Karachi: Sindhi Adabi Board, 1909), 316 


\section{The Notions of Tribe and Ethnicity}

The term 'tribe' is used in my thesis for certain communities in Sindh that are referred to as 'mardum' (people) and 'kabail' (tribe) in the contemporary sources. ${ }^{17}$ This differs from its usage by the colonialists, who considered all of the tribes in Central and South Asia to be 'savages'. It has even been argued that the colonialist invented the term tribe to justify colonialism. The term 'crimainal tribes' was invented by the British ethnographers around $1871 .{ }^{18}$ We therefore need to define what is understood by the term 'tribe', for here was and is considerable variety among tribes. The word tribe is context specific, and there is no universally accepted definition of the word beyond agreement that it is a bounded community with certain traits, such as similar economic functions or a self-contained economy. Tribes are largely egalitarian but we have references to hierarchies emerging within them at various phases of their history; an example is the Kalhoras when they were becoming feudalised. There is general agreement among scholars that tribal organisations are separate from state systems. In the discussion that follows, I draw on some of the important scholarship on tribe and tribalism in order to understand the historical process of attempted state formation by the Kalhora tribe of Sindh.

For Morton Fried 'tribe' is a problematic word that has been used in ways that are often ambiguous or confused. He says that different tribes are not separated from each other by cultural, economic or political boundaries. The conventional definition of tribe is, therefore, inadequate. According to Fried, tribe was a 'secondary socio-political phenomenon' and a 'pristine tribe' never actually existed. Tribalism emerged as a reaction against states. It was a phenomenon of ethnic group formation and secondary tribal identity came into being a result of conflict between groups. According to him, groups of people are transformed into a 'secondary tribe' due to certain catalysts such as state intervention, ideological pressure from

17 Muhammad Saleem Akhtar, Sind under the Mughuls: An Introduction to Translation of and Commentary on the Mą̣har-i Shāhjahānī of Yūsuf Mīrak, 1044/1634 (Islamabad, Pakistan; Karachi: National Institute of Historical and Cultural Research ; Dept. of Culture, Govt. of Sindh, 1990). 165

18 Susan Abraham, “'Steal or I'll call you a Thief' : Criminal Tribes of India”, Economic and Political Weekly, V. 34, no. 27, July 3-9, 1999, 1753. 
missionaries or non-official reasons such as the emergence of a trade route. A state, when it expands, creates citizens and slaves within it and those who resist and struggle against this expanding state, form themselves as tribes. 'Secondary tribe' could also be created by a state to facilitate tribute collection from marginal or less developed groups. Thus, Fried says, tribe as a phenomenon came into being after pristine states evolved into more politically complex organisations or states. ${ }^{19}$

D.N. Majumdar explained the word tribe in the British Imperial Gazetteer as 'a social group with territorial affiliation, endogamous, with no specialisation of function, dialect attached in the case of a caste structure, following tribal traditions, beliefs and customs, illiberal of naturalisation of ideas from alien sources, above all conscious of homogeneity of ethnic and territorial integration. ${ }^{20}$ B.B. Sinha gives a similar definition of the word tribe in the Indian context as 'a group of people characterised by a common and distinct name, a group- sentiment, and a common and specific territory. It is endogamous and has common institutional agencies. A tribe follows its own specific magic and rituals along with other social, economic, political and cultural traditions. Each particular tribe has its own code of conduct and practice and conventional taboos. ${ }^{, 21}$ Sheren F. Ratnagar argues that a tribal society is structured on the basis of kinship. As opposed to case society it is 'non-hierarchical' and culturally homogenous. She further argues "the major distinguishing feature of tribal society is the common entitlement to major natural resources, agricultural land, ground water, water courses and tanks, cremation grounds and cemeteries, market places, pastures and forests”. In contrast, state makers prefer individual ownership. Thus tribal structures are described as 'acephalous' by Ratnagar. ${ }^{22}$

During the British period, certain groups within India were labelled as 'criminal tribes' by the Act of 1871 because, as David Arnold suggests, their 5 .

20 D.N. Majumdar and T.N. Madan, An Introduction to Social Anthropology, (Bombay: Asia Publishing House, 1956), 241.

21 B. B. Sinha, Society in Tribal India, (New Delhi: B.R. Publishing Corporations, 1982), 2.

22 Shereen F. Ratnagar, 'Concluding Summary' in Rudolf C. Heredia and Shereen F. Ratnagar eds. Mobile and Marginalized Peoples: Perspectives from the Past,(Delhi: Manohar, 2003), 224-226. 
wandering and pastoral activities were considered as 'unproductive' and did not serve the colonial interest of having settled agricultural communities or wage-laboured economy. ${ }^{23}$ This raised questions among many ethnographers, anthropologists and historians about the usefulness of the word 'tribe' as a label to understand certain communities in India. Historians began to question racial arguments based on 'biological determinism' that argued that criminal traits among groups like the thugees (roving bands of robbers) became hereditary among certain 'criminal tribes', Our study of Sindh does show that certain tribes like Nahmardis and Khosas were indeed plunderers and looters. But, as we shall see below, this was a way of life dictated by availability of resources, not a hereditary trait, and not all the tribes of Sindh followed such a way of life all the time. ${ }^{24}$

European colonists used the term 'tribe' to describe the aboriginal or primitive people in the colonies to emphasise their primitive or uncivilized traits. At issue is whether colonial ethnographers gave the word a primordial ethnographic meaning, or that they used it either to demean Indian communities or to understand their complexities. We must ask, therefore, whether the colonial representation of Sindh were of an 'imagined' Sindhi society divided on the basis of primordial ethnicity defined into tribes, or whether these tribal groups actually existed in Sindh in the way depicted in the anthropological records of British Ethnographers such as H.A. Rose or Denzil Ibbetson. ${ }^{25}$

The colonial attempt to study the Indian past and its society started after the Great Revolt of 1857-58 in many parts of India. The revolt was, at the time, attributed to the hurt cultural sensitivities of the Indians, and the British thus declared that they would not interfere with or disrupt the existing social arrangements. To this purpose they needed to know the society that they had now Province (Lahore: Superintendent, Government Printing, 1911), Denzil Ibbetson, Punjab Caste, (Punjab: Government Printing, 1916). 
resolved not to change. Thus started the great Victorian enterprise of studying the Indian past.

Nicholas Dirks is of the view that the British ethnographic study created, an 'invented' and 'imagined' India, divided into hierarchies of castes and tribes. The standard classification of Indian society into tribes and castes was the result of western colonial attempt to essentialize India. ${ }^{26}$ Susan Bayly on the other hand argues that the colonial ethnographies of Indian society cannot be dismissed altogether as they reveal a great deal about its regional complexities. ${ }^{27}$ The Indian ethnographers, who wrote in the late 19th century, drew on the new scientific ideas that had emerged at the time about evolution. In this respect they differed from the eighteenth century scholars who understood race from a linguistic or environmental perspective.

Bayly says that the colonial literature expressed a particular notion of race and applied theories of evolution to India in an attempt to understand Indian society. ${ }^{28}$ Nandini Sunder points out that the colonialists viewed terms like "“tribal', 'primitive', 'savage', or 'wild"' as hierarchal categories which justified colonial rule in India. The tribes of both India and Africa were categorised according to the principles of evolution and this ordering was based on 'the denigration of any indigenous kingship in favour of an acephalous, kinship bound society and the perceived primitiveness of modes of production. ${ }^{29}$

However not all colonial ethnographers who worked on India were in agreement about the nature of Indian society, nor did all invent categories such as caste and tribe to fabricate or essentialize India. Their work, simply grouping people from all the places into a uniform hierarchies of caste, shows how ethnically distinct were regions such as the Punjab, the North West Frontier Provinces, Bengal, South

Nicholas Dirks, 'The invention of Caste: Civil Society in Colonial India', Social Analysis, September 25, 1989.

27 Susan Bayly, 'Caste and Race in the Colonial Ethnography of India.' in Peter Robb ed. The Concept of Race in South Asia, (Delhi: Oxford University Press, 1995), 167.

28 Ibid.

$29 \quad$ Nandini Sunder, Subalterns and Sovereigns: An Anthropological History of Bastar (18542006), $2^{\text {nd }}$ ed. (Delhi: OUP, 2011), 11.
} 
India and Maharashtra etc. were. Verrier Elwin (d.1964), the British functionalist anthropologist and ethnographer who worked among the Gonds in Central India, appreciated that they could not be labelled as savages for they had a 'rich' and 'vigorous culture' full of 'artful way of storey telling, good music and fine dancing' ${ }^{30}$ He said that the colonial state 'despised' and 'callously ignored' them and the 'nationalist intelligentsia' considered them as 'cyphers in the population of India'. Elwin described the tribal people as autochthones who loved nature rather than 'primitive' or 'savage'. Forests had 'economic, cultural, practical as well as symbolic' significance for them and they divided land equally among themselves. ${ }^{31}$

Colonial ethnographers like W.W. Hunter and H.H. Risely viewed caste as races and caste hierarchies as racial hierarchies. ${ }^{32}$ The nineteenth century also saw the emergence in Europe of the myth of the Aryan race and its superior civilization. ${ }^{33}$ In relation to India, Orientalists such as Campbell talked about Brahmans as of 'old Aryan' race. ${ }^{34}$ They evolved the 'less democratic', institutions categorised as castes. Denzil Ibbetson, who worked on the castes and tribes of Punjab, viewed castes in the Punjab like Rajputs, Thakur and Jat. as terms signifying political power and were not rigidly fixed. Rural Punjab was thus 'non-caste' like in character. Furthermore, 'caste' was not exclusive to Hindu society. Muslims too assigned identities such as Saiyids, Qureshis, and Arabs etc. Sikhs also defined identities such as the Jat, Khatris or/and untouchables. Ibbestson thus argues that the Punjab had people divided into tribes and not castes. ${ }^{35}$ These tribal identities in the Punjab, like 'Chauhan', 'Sial' and 'Punwar', were linked to the possession of agrarian land and

Ramcharda Guha, 'Savaging the Civilized: Verrier Elwin, His Tribals, and India' in The Ramchandra Guha Omnibus, $4^{\text {th }}$ ed. (New Delhi: OUP, 2009), 111.

Ramchandra Guha, 'Savaging the civilized, Verrier Elwin and the Tribal Question in the Late Colonial India', Economic and Political Weekly, Special No., September 1996. 23752383.

Ramcharda Guha, Savaging the Civilized: Verrier Elwin, His Tribals, and India in The Ramchandra Guha Omnibus, $4^{\text {th }}$ ed. (New Delhi: OUP, 2009), 169. Indira Chowdhury Sengupta, 'The Effeminate and the Masculine: Nationalism and the Concept of Race in Colonial Bengal', in Peter Robb ed. The Concept of Race in South Asia, (Delhi: OUP, 1995), 284.

Susan Bayly, 'Caste and Race in the Colonial Ethnography of India.', 192. Denzil Ibbetson, Punjab Caste, 5,25, 
the power that went with it. ${ }^{36}$ Thus caste in the Punjab was not an ethnographic fact but a historical one, depending on land control, local power, political patronage and status, all of which were dynamic. Thus there was social mobility among members of castes.

But unlike in the Punjab, where caste and tribal identities altered according to the access to power and status, the tribal identities in Sindh gradually became more closed, rigid and crystallised during the eighteenth century. But even after shifting from pastoralism to a sedentary lifestyle and developing an agricultural economy, certain tribes of Sindh, such as the Baluch and Panwars, were not transformed into castes. Tribal societies were usually transformed when a state imposed its great tradition on them. In Sindh, however, the Mughals did not interfere with the local society, therefore Sindh still remained tribal in the eighteenth century. The geographic isolation of some of its tribes like the Baluchs, Samejas, Unar, Nuhmardis and, Pakhtuns added to the process of consolidation of tribal identities. ${ }^{37}$

Tribes such as the Baluch of the Upper Sindh and Dera Ghazi Khan and the Pakhtuns of the central Sindh, pursued livelihoods that were a mix of pastoral herding, trade and plundering. ${ }^{38}$ The drive to control resources underpinned intratribal relations and intra-tribal kinship alliances. Nonetheless, tribal identities were ethnically based and different tribes claimed descent from the same patriarch. David Gilmartin studied the role played by irrigation in the process of state building by the Baluch tribe in the Central Sindh. He says that the political structure of the Baluch was based on an 'ideology of reciprocal obligation'. ${ }^{39}$ The authority of the Baluch chief was checked by the several segmentary chiefs under him who in turn were checked by the elders within the segments they controlled. The 'lavish generosity' in

Ibid., 5, 25.

Mazahar-i-Shahjahani and Tuhfat-ul-Kiram mention many such tribes of Sindh. David Gilmartin, 'Irrigation and the Baloch Frontier', in Mansura Haider ed., Sufis, Sultans and Feudal Order (New Delhi: Manohar, 2004), 331. Ibid., 335. 
distribution of wealth among the tribesmen and, success in tribal raids determined the success of the Baluch tribal chiefs. ${ }^{40}$

The success of the Kalhora, tribal chief depended on his ability to distribute equally among his followers the wealth, generated through agriculture carried out communally by his followers. They were also Sufi pirs (religious master) and their followere were disciples (muridain) bound by piri-muridi relationship (explained below). As spiritual leaders they were supposed to fulfil the moral aspirations of their devotees, in addition to meeting their material needs. To maintain this support base they needed to expand their access to cultivable land through conquest in the areas of the neighbouring landed and tribal elites.

The early history of the Kalhoras was thus shaped by the search and retention of cultivable land. This obviously involved incessant warfare between the tribes. The burial places of the Kalhora chiefs enable us to track the path of the tribe's search for arable land on which it could settle and build its religious followings. In other words, the geographical location of Kalhora tombs and the techniques of settlement uncovered by archaeologists allow us to establish the migratory routes of the Kalhoras and the means by which they developed their state building. The tomb of Adam Shah, a Kalhora chief of the sixteenth century, was in Sakhar, a plain region with a stable Indus bed in northern Sindh. ${ }^{41}$ The location of the tombs of the other chiefs show a movement of the tribe towards southern Sindh; examples include the tomb of Yar Muhammad Kalhora (d. 1718) in Khudabad, towards the south of Sakhar, and the tomb of Noor Muhammad Kalhora (d. 1738), which is eighteen miles further south of Khudabad. ${ }^{42}$ These locations show that the Kalhoras were semi-pastoral and wandered about the Northern Sindh and Baluchistan, warring with local tribal chiefs of, for example, the Gujjars and Panwahrs, in order to acquire land. ${ }^{43}$ However, for understanding the basis of their political power and the history

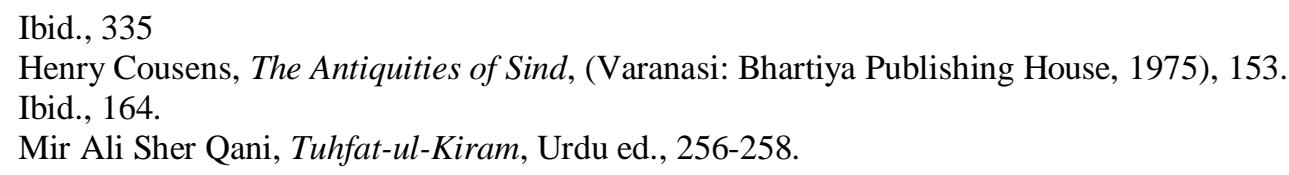


of state formation, it is crucial to underatand the Sufi tradition and the piri-muridi relationship, which is discussed below.

\section{Sufism and the Piri-Muridi Relationship}

The word 'Sufi' is derived from the Arabic term 'suf' which means 'wool', because apparently the early Sufis clad themselves in coarse woollens when Sufism emerged in the $8^{\text {th }}$ century. Sufism has been defined as 'Islamic mysticism' by most scholars who have written on the subject. Historians like Muhammad Habib, K.A. Nizami, S.A.A. Rizvi, Bruce Lawrence and Carl Earnest regarded the Sufis as mystics who kept away from the state, politics and materialism. ${ }^{44}$ Modern historians like Richard Eaton, Simon Digby, Muzaffar Alam and Riazuddin Aqil have however contended that the Sufis were indeed involved in politics, had relations with the state and visited the state court. Raziuddin Aquil, suggests that Sufism should be rather defined in its historical context, as Sufis were social actors who dealt with the state and non-Muslims in the society. ${ }^{45}$ My work on Sindh also suggests that the local Sufi dynasty of the Kalhoras were arm bearers who rose to political prominence in the eighteenth century and were appointed as Mughal mansabdar before they emerged as independent rulers of Sindh in 1736. This section on Sufism will be followed by a discussion of the practices of Sufism in order to understand the state administration established by the Sufi Kalhora dynasty.

To understand the nature of Sufis we have to consider the social milieu in which they lived and developed. Sufism evolved in phases and its practices changed over a period of centuries. In its first phase, during the eighth century, Sufism emerged as a personal religion against institutionalised religion. ${ }^{46}$ This phase was called the Khanqah phase and can be sub-divided into two: in the eighth century the Sufis were wandering ascetics and lived a withdrawn life; in the ninth century they developed a 'love for God' rather than 'fear of God' and are described as the 'early

\footnotetext{
Ibid., x, xi.

Raziuddin Aquil ed. Sufism and State Society in Medieval India, (Delhi: OUP, 2010), vii. Carl W. Ernst and Bruce Lawrence, Sufi Martyrs of Love: The Chisti Order in South Asia and Beyond, (London: Palgrave Macmillan, 2002), 11.
} 
mystics'. The rest-houses for such wandering Sufis and 'early mystics' were called the Khanqahs or convents, places where Sufis led a life of asceticism, practising devotion under the guidance of their Pir (master). However the bond and difference between the Pir (master) and Murid (disciple) was not formal in this phase. ${ }^{47}$

J. Spenser Trimingham says that the form of Sufism based on the hierarchical chain of Piri-Muridi (master-disciple) system emerged in the second stage of its development, also known as the tariqa phase. This phase started during the twelfth century. The master-disciple relationship became the founding stone of the Sufic order. A Master was a wali, or 'protégé of God' or 'friend of God', and believed that everyone can come out of one self (fana or transmutation of self) and reach out to God spiritually by following his guidance by way of tariqa ${ }^{48}$ Trimingham says 'a tariqa was a practical method to guide a seeker by tracing a way of thought, feeling and action, leading through a succession of 'stages' (maqamat) to experience the divine reality (haqiqa) ${ }^{, 49}$ Sufis thus came to believe that they could have a direct communion with God by following a certain path (salak at tariqat). This path could be learned under the guidance of a Pir who used his intuitive and/or cognitive power to have direct union with God and terrestrial world. ${ }^{50}$

Writing about early Sufism's second phase, Bruce Lawrence said that, a Sufi master, also known as 'Shaikhs, Mashaikh, Pirs or Murshids' was often 'reclusive' or 'apolitical'. ${ }^{51}$ A Shaikh had authority over all aspects of the lives of his followers. He was considered as a perfect man and 'sole vehicle to divine grace'. ${ }^{52}$ He was the only means through which others could connect to the God. He was idolized by his followers, who showed him allegiance by means of acts such as bait (offering an oath of allegiance) or qadambushi (kissing the feet). Every saint was expected to behave like the Prophet Muhammed in his everyday conduct. He was supposed to be

Richard M. Eaton, Sufis of Bijapur, rev. ed. (Delhi: Munshiram Manoharlal Publisher Pvt Ltd), xxvii-xxix.

J. Spenser Trimingham, The Sufi Orders in Islam, $2^{\text {nd }}$ ed. (New York: OUP, 1998), 3-13. Ibid., 3. Ibid., 1-2. Bruce Lawrence, 'The Earlist Chistiya and Shaikh Nizam ud Din Awilya (d.1325)' in Percival Spear and Narayani Gupta ed. The Delhi Omnibus, 105. Ibid., 110. 
a prototype of the Prophet with a 'chain of descent' (shajra) going back to either of the Prophets' male grandchildren- Hasan or Husain. To this Simon Digby adds that a Sufi saint should be attached to a Sufi silsila (order) and live a life of austerity and maintain strict orthodoxy. He should also be able to perform miracles (karamat), but in a limited manner. He should be 'inaccessible' and 'dislike human society' but was expected to take care of his disciples and visitors. ${ }^{53}$ Yet he should live in a city or near it and stay in touch with 'worldly people, merchants, soldiers, government officials and kings through his lay disciples. ${ }^{, 54}$ The early Sufi master therefore did not emulate the Muslim prophet who was a 'merchant, warrior, statesman and arbitrator. $^{, 55}$

Sufism emerged as an institutionalised form based on ta'ifas or organisations in its third phase during the fifteenth century. The saint's tombs now gained prominence in the religion and his followers regarded the possession of it to be a means of inheriting the saint's spiritual power. ${ }^{56}$ These tombs called dargahs in India replaced the khanqahs and attracted visits by people who, rather than seeking to achieve their 'mystic's goal of spiritual affinity with God, had simpler aim of achieving relief from worldly anxieties or of attaining worldly desires. ${ }^{57}$ Carl Earnst says that in this phase Sufism emerged in its contemporary form; that is, it was no longer 'pure mysticism' and became a state sponsored mass religion.

The Sufis in the subsequent period, as suggested by Richard Eaton, could be found in any of these roles: 'warrior', 'reformer', 'literati', 'landed elite' or 'dervishes'. His study of Bijapur suggests how Sufis like Gesudaraz played the role of kingmakers in the Bahmani Kingdom. Simon Digby suggests that in the Punjab also the Sufis were politically active. In the eighteenth century when a political vacuum occurred there, the then Chisti Sufi Divan tried to take political power, but

\footnotetext{
53 Simon Digby, 'Tabrrukat and Succession Among the Great Chisti Shykhs of the Delhi Sultanate' in R.E.Frykenberg ed. Delhi Through the Ages (New York: OUP, 1994), 109. Ibid, 110. Ibid. 107. Ibid., 90. Eaton, Sufis of Bijapur, xxvi.
} 
was ousted by Raja Ranjeet Singh. ${ }^{58}$ The Sufis' role in local politics in Pakpattan in the nineteenth century made the British administrators of that time describe them as 'a semi - religious mussalman tribe'. ${ }^{59}$ Sarah Ansari's work on Sindh also suggests that the Sufis of Sindh were social actors who played the role of mediators or middlemen between the 'tribes' and the states. The Mughals, recognizing the important role played by the members of religious families and Sufis made several revenue free land grants (inam) to them. ${ }^{60}$

Sindh has been called a land of Sufis and many of them came from Iran, which added to their numbers in Sindh. The Sufis of Sindh worked as government employee and some of them even worked in the court of Delhi. ${ }^{61}$ The Kalhora Sufis of Sindh too, were social and political actors who evolved from 'semi-pastoralists' to settled 'warrior-Sufis" ${ }^{62}$ before becoming the semi-independent rulers of Sindh under the Mughals. The spiritual relations between the Kalhora Pirs and their Murids developed into a patron-client relationship, wherein the head of the sect had the duty to materially support his devotees. Hence there was a need for resources, in the form, mainly of land and the development of agriculture.The search for resources led to competition for land with the other chiefs and with Sufis who were already entrenched in the region. As a result, the Kalhora Sufis, originally a devotional group, were transformed into a martial group. In the process of political struggle for land and loyalty in Sindh the Kalhora sect sought religious legitimacy through their claim of Sajra (chain of descent) going back to Hazrat Abbas, the Prophet's uncle. The next section of this chapter will explain the way in which the Kalhoras claimed Sajra and established their political power and social legitimacy in Sindh.

Digby, 'Tabrrukat and Succession', 93.

Ibid., 94.

Sarah F. D. Ansari, Sufi Saints and State Power: The Pirs of Sindh 1843-1947, (Cambridge: Cambridge University Press, 1992), 24-29.

61 Thattavi, Tuhfatul-Kiram, Urdu ed. 38.

62 'Warrior-sufis' is a term used by Richard Eaton for Sufis of Bijapur in the medieval India. Richard Maxwell Eaton, Sufis of Bijapur, 1300-1700: Social Roles of Sufis in Medieval India, (Princeton: Princeton University Press, 1978), 19. 


\section{The concept of Shajra and legitimacy in the medieval Sindhi society}

Writing about the development of tribal organisations into more complex form of organisation and state building, Edward Adamson Hoebel has argued that, 'the essentials of legal coercion are general social acceptance of the application of the physical power, in threat or in fact, by a privileged party, for the legitimate cause, in a legitimate way, and at a legitimate time. ${ }^{63}$ In other words the coercion exercised by a state can be considered to be legitimate if it has been validated by mass acceptance. ${ }^{64}$ This need for validation and legitimacy was felt by the Kalhoras during the pre-state stage of their state building. In order to validate their power in society they traced their Shajra or chain of descent back to al Abbas b. Abd al Muttalib (647 -680), the uncle of the Prophet. Maathir-ul-Umra, an eighteenth century work by Shah Nawaz Khan, tells about the Kalhoras that the nisab (according to Islamic law, it is the minimum amount in one's possesses that is liable for zakat taxation) ${ }^{65}$ of the then Mughal Jagirdar (holder of Jagir land) of Sindh was 'Abbasi' and the laqab (title) of their family in the Sindhi dialect was 'Kalhora'. 66

According to the nineteenth century source Jawahir-i-Abbasia by Shaikh Mohammad Aazam, the Shajra of the ancestors of the Kalhoras goes back to Hazrat Abbas through Harun al Rashid, the Abbasid Caliph of Baghdad. ${ }^{67}$ The descendent of the first Abbasid caliph of Egypt came to India because the then ruler of Delhi, Muhammab bin Tughlaq (1325-1351), revered the Egyptian Caliph and obtained Mansur, or permission to rule, from him in 1326. The Indian ruler's deep reverence rev. ed.(Harvard University Press, 2006 ), 27.

Ibid, 27. Academy, 1979), 101. Zakat is the obligatory tax which all Muslims have to pay to the state. Nawab Shams ud Daula Shah Nawaz Khan, Mathir-ul-Umra, V.1, ed. Maulavi Abdul Rahim, (Calcutta: Royal Asiatic Society of Bengal,1888), 825. The Sajra of the Kalhoras in Jawahir-i- Abbasi, 38-39, is mentioned as : Mohammad Chane Khan bin. Bhela Khan b. Thal Khan b. Sankrasi Khan b. Kahar Khan b. Abban Khan b. Sultan Ahmed Sani b. Sultan Shah Mazmal b. Sultan Aqil b. Sahel b. Sultan Yaseen b. Khalifa Ahmad I b. Muntasar billa b. Khalifa Shah Mazmal b. Khalel Sultan Abu Al'Fazl b. Sultan Abu Jafar Abdulla b. Khalifa Muhammaf Ameen b. Khalifa Sultan Harun al' Rashid b. Khalifa Muhammad Mehdi b. Khalifa Abu Jafar Mansur b. Muhammad b. al Abbas b. Abd al Mutallib. 
for the Egyptian caliphate made a person from this family motivated to look to India as a land of opportunity and, therefore to settle here. The Shajra of the Kalhoras which these sources claim is however historically incorrect as the Abbasid Caliph of Egypt, Ahmad I Muntasar Billa referred to in the Shajra was not the son of Caliph Shah Mazmal; he was the thirty-fifth Abbasid Caliph of Bagdad Al- Zahir bin Amrillah. $^{68}$

From these scattered references about the prominent men of the tribe of Kalhoras, albeit without any chronological detail, one could say that the Kalhoras sought to establish their hegemony over the territories they conquered by claiming a Shajra back to Abbasi: their aim was to overawe the people of Sindh of that time and to prove themselves as more worthy Islamic leaders than other Imams or Shaikhs with less prestigious Shajra. Waging war was another means of subduing or displacing local population, very much like the way in which the state expanded under the Ummaiyid and Abbasid Caliphs in the Mediterranean and Sindh region. It was the interplay of religion and valour in tribal war which helped chieftains succeed in establishing new states. We do not know whether the new state was Islamic to begin with, or if it was first ruled according to tribal principles.

Even after coming to power, the Kalhoras continued the Sufic tradition of succession as sajjada nashin. ${ }^{69}$ The new state's religious character gave it political in Sindhi society, which was multi- religious. It incorporated people from a variety of Islamic and Indic sects, namely the Sufis belonging to Shurawardi, the Chisti, Qadiri and Naqshbandi sects, the Mahdawis, other Saiyids, Sunni and Shia sects. ${ }^{70}$ Sindh society was characterised by both sectarian conflict and cooperation, and the Kalhoras claiming a Sajra from none other than the Prophet's uncle al Abbas b. Abd

68 Ghulam Rasool Mehar, Tarikh-i-Sindh, V.1, (Karachi: Sindhi Adabi Board, 1958), 50.

69 Sajjaah Nashin (one who sits on the prayer carpet) is the successors of a sufi pir. Justin Jones and Ali Usman Qasmi, The Shi' a in Modern outh Asia, Religion History and Politics, (Delhi: Cambridge University Press, 2015), 160.

70 Saiyd Athar Abbas Rizvi, History of Sufism in India, V. 2. (Delhi:Munshiram Manoharlal, Publishers Pvt. Ltd. 1978), Murray T. Titus, Islam in India and Pakistan, a Religious History of Islam in India and Pakistan, ( New Delhi: Munshiram Manoharlal Publishers Pvt. Ltd., 2005). Arshad Islam, Islam in Sindh, (Malaysia: International Islamic University of Malaysia, 2001), 116-154. 
al Mutalib could claim a political advantage in the conflicts. The claim was particularly powerful because al Abbas was venerated by all the adherents of Islam. In the eyes of the people, it legitimated the Kalhora rule as guardians of their sacred domain. This was important, because in medieval Sindh, as in the rest of India, the religious and political domains were not separate, and ruling elites needed to be legitimised as the representatives of the sacred domain. ${ }^{71}$ The Kalhoras, however, combined control over both the sacred and the temporal domains, so the religious head of the dynasty was also the head of the state. Rather than using any high sounding titles for themselves, as the other rulers of the time, they called themselves 'Khadim-ul-Fuqra' or the 'servers of mendicants'. ${ }^{72}$ Their followers were also their administrators so that a kind of tribal confederacy evolved

When a Pir of any Sufi sect claimed leadership, his followers fell in behind him and supported the new regime. The Pirs of Sindh had a large following among the local landed people most of whom were Muslims. The countryside here was dominated by the Muslims; the Hindus in Sindh were mainly engaged in commerce and trade. The Sufi sect to which the Kalhoras belonged was Suhrawardi. They later became followers of the Mahdawi sect, only to again shift their loyalty back to the Suhrawardi Sufi Pirs. ${ }^{73}$ Being both landed elites and Sufi Pirs, it was easier for them to win followers among the native tribes and to keep them committed to their faith while new political structure developed. The new system could be sustained through the new rulers' control over resources, acquired forcefully and later legitimised by the declining Mughal state. Kalhora ruler Yar Muhammad Khan was given a Mughal administrative post of 5000 mansabdari and a title of Khuda Yar Khan (Friend of God) by the Mughal state. Their rule was legitimised in Sindh in 1737 when possession of Thatta was given to them after the last Mughal governor Sadiq Ali

Brajadulal Chattopadhyaya, The Making of Early Medieval India, $4^{\text {th }}$ ed. (New Delhi: Oxford University Press, New Delhi, 2005), 197.

Munshi Abdur Rauf, Guldadtan-i- Norais Bahar, MS. 34 (Karachi: Rashidi Collection, n.d.), 58.

Kalhoras Sufis, before Adam Shah Kalhora, were followers of Sayed Hasan Shah Bhukhari, who was probably a Shurawardi Sufi from Siwistan in (Tuhfat-ul-Kiram, Urdu translation, 449) Adam shah Kalhora during the time of Akbar became adherent of Mahdawism. Thattavi, Tuhfat-ul-Kiram, Persian ed. 22. 
Khan was unsuccessful in subduing the region. Eventually they were made the Subadar (in charge of the Suba or province) of Sindh, which recognised them as semi-independent rulers of Sindh under the suzerainty of the Mughals. ${ }^{74}$ The members of the Kalhora tribe and their followers were also involved in cooperative production. Together they seized land from the other tribes and groups, and the Kalhora ruler organised and distributed produce among his followers, just like other Sufi Pirs did among their disciples in their khanqahs. We do not know, however, if farm produce and resources were distributed equally among followers, or if distribution was based on work contributions.

The Kalhoras' relationship with the neighbouring tribes and religious groups in Sindh was warlike. Followers entered into a master-disciple relationship with them, like other Sufic Piri-Muridi relations but with a difference; Kalhora disciples waged war on their leaders' behalf with the rival tribes. Unlike the Chisti Sufi sect of India, in which the Baraka or the spiritual authority of the Pir descended to the most worthy disciple, among the Kalhoras the lineal succession to Pirship cum rulership was based on descent from a Kalhora This sacred lineage was maintained within the Kalhora family and their disciples seldom tried to arrogate any of the temporal or sacred authority to themselves, ${ }^{75}$ except when they were overthrown by their followers, the Talpur Baluch who became state ruler in Sindh in 1783.

\section{Evolution of the Kalhora State}

The first attempt to document the history of the Kalhoras was made by the eighteenth century scholars. The eighteenth and nineteenth century sources writing about the origin of the tribe only provide lists of unilineal descendants from their ancestor called Odhana. According to Tuhfat ul-Kiram (gift of miraculous deeds) the ancestors of the Kalhoras were Arabs. Odhana, a member of this tribe came to

\footnotetext{
74 Kalhora ruler Yar Muhammad Khan was given Mughal administrative post of 5000 mansabdari and and a title of Khuda Yar Khan (Friend of god). Their rule was legitimised in Sindh in 1737 when possession of Thatta was given to them after the last Mughal governor Sadiq Ali Khan was unsuccessful, Ghulam Muhammad Lahko, Kalhora Daure Hukumat (Reign of the times of Kalhora), (Karachi: Athad Ebasea Pakistan), 125.This will be discussed in detail later in the chapter.

75 Lakho, Kalhora Daure Hukumat.
} 
Makran and established himself as a religious leader. ${ }^{76}$ The source however does not give any biographical information about this person, including where he came from. It further says that after many generations a person from this family called Thal moved to Khairbela and settled with his tribesmen there by uprooting the tribe of Gujjars. He was succeeded as tribal leader by a person called Bheel, who was followed by his son Chane Khan. ${ }^{77}$ This unilineal descent community (their descent being exclusively through male-line) had no prior territorial anchorage; they became established in Sindh by warring with the other local tribes and marrying into their families. ${ }^{78}$ In the process the clan's original characteristics might well have changed. What did not change however, was the religious role played by the clan leader; he remained the religious head of the tribe.

There are many local traditions in Sindh about how the tribe came to be known as Kalhoras and 'Abbasssi'. The term 'Kalhora' is derived from a Sindhi word 'Kalho' which means alone. The Sindhi word 'ro' is added to it as a diminution. They acquired this name because they were known to live a simple and religious life, in comparative solitude; their down to earth life style was also noted. ${ }^{79}$ Another opinion about of the tribe's nomenclature is that one of their ancestors came from Kilore, a place which was to the north of Hyderabad. ${ }^{80}$

The laqab 'Mian' or 'Shah' by which the Kalhoras were famously known in Sindh expresses the reverence in which they were held by their followers; the strength of their following enabled them to compete for political power in eighteenth century Sindh whose inhabitants included people of high social standing; examples include the Sadat (plural of Saiyid, that is those who claimed descent from the Prophet's family), Irani and Turani. Collectively the Kalhoras were also known as 'Sarais'. The word 'Sarai' is derived from the Sindhi word 'Sara' which is used for

Thattvi, Tuhfat-ul-Kiram, Urdu ed., 317.

Lakho, Kalhora Daure Hukumat, 76.

Thattvi Tuhfat-ul-Kiram, Urdu ed., (Karachi: Sindhi Adabi Board, 1909), 317-319.

Mehar, Tarikh-i-Sindh, V.1, (Karachi: Sindhi Adabi Board, 1958), 124. Ibid., 127. 
upper Sindh, the area between Multan and Bhakkar. The Kalhoras lived in upper Sindh or Sara hence they were also known as 'Sarais'. 81

In 1590 the Mughal commander Abdur Rahim Khan-i-Khanan, while leading an expedition in Sindh, asked Adam Shah Kalhora, the eponym of the dynasty and a famous Pir at that time, to pray for his success. In return he offered Adam Shah the jagir of Chanduka Taluqa, which until then belonged to the Chandya tribe. ${ }^{82}$ Adam Shah used this land as a base for his religious sect and its followers. During this time Adam Shah's following further increased in number and this enabled him to extend his territory by seizing land from other zamindars. The dispossessed zamindars and landed elites complained to the Nazim of Bhakkar about Adam Shah, resulting in his arrest. The Mughal Nazim, did not approve of the religious pretentions of Adam Shah and arrested him. He was taken to Multan and executed. ${ }^{83}$

The period to which Adam Shah belonged cannot be dated precisely. Lala Daulat Rai in Mirat-i-Jawahir-i-Abbasi (treasure trove of the times of Abbasids) says that he lived around $1475 .{ }^{84}$ Khan Bahadur Khuda Dad Khan, the author of Lubb-i-Tarikh-i-Snidh (understanding history of Sindh) says that, he lived in $1450 .{ }^{85}$ According to Mir Sher Qani Thattvi, the author of Tuhfatul Kiram, Adam Shah was a murid (disciple) of a murid of the Mahdawi saint Mian Saiyid Muhammad Jaunpuri (1505) who had lived three generations before him. The name of the murid is given as Shaikh Abu Bakar Jatoi; he was murid of Shaikh Ilyas Lankraj, and had initiated Adam Shah into the sect of Mahdawism. ${ }^{86}$ Mahdawi was a socio-religious movement which was developed in India by Saiyid Muhammad Jaunpuri in the sixteenth century. It was based on the messianic doctrine of Islam which took root during the politico-religious chaos that followed the death of the Prophet in the seventh century. It made the Shias expect the coming of an 'al- Mehdi or restorer of

Nawab Shams ud Daula Shah Nawaz Khan, Mathir-ul-Umra, V.1, ed. Maulavi Abdul Rahim, (Calcutta: Royal Asiatic Society of Bengal, 1888), 825.

Thattvi, Tuhfat-ul- Kiram, V.3 Persian ed. (Karachi: Rashidi Collection, M.S.), 103. Thattvi, Tuhfat-ul Kiram, Urdu ed. 318-320 Lala Daulat Rai, Mirat-i-Daulat-i-Abbasia (Karachi: Sindhi Adabi Board,1882), 71. Khan Bahadur Khudadad Khan, Lubb-i-Tarikh-i-Sindh (Karachi: Rashidi Collection, M.S.), 106. 
faith' ${ }^{87}$ The expected $a l$ - Mehdi was to be a 'deliverer of Muslims' and would be from the family of the descendants of Ali. This idea of an expected Messiah mirrored the Christian belief of the 'second coming of Christ'. ${ }^{88}$ Many ambitious socioreligious Muslim leaders had declared themselves to be al- Mehdi before Saiyid Muhammad Jaunpuri declared himself to be so in India. ${ }^{89}$

Noor Muhammad Kalhora, in his will Mansur ul Wasiyat wa Dastur ul Hukumat (prose written about will and constitution of administration) said that Adam Shah was a disciple of a fourth generation disciple of Jaunpuri. ${ }^{90}$ He also said that out of the existing fourteen schools of Tasawwuf(Sufism), his Pir-i-Tariqat or the branch of Sufism was Shurawardi. ${ }^{91}$ Not all the disciples of Saiyid Muhammad Jaunpuri considered him to be the expected Mehdi. Adam Shah was initiated into the Mahdawi sect as a Shuhrawardi Sufi. The Kalhoras were Hanafi Sunnis by faith and did not believe in the concept of Mehdi and, therefore, did not anticipate the arrival of a Messiah. ${ }^{92}$

The death of Adam Shah Kalhora by the order of the Mughal governor won the Koalhoras the sympathy of the native Sindhis, and so the number of their followers further increased. ${ }^{93}$ Adam Shah was succeeded by his son Daud Khan on the prayer carpet and leadership of the tribe. It was during the time of Daud Khan Kalhora that the sect obtained support from the government when a Mughal officer of Multan allowed the Kalhoras to revive their sect. Ilyas Kalhora succeeded Daud Kalhora; his leadership saw an increase in the following of the sect, which now also included members of the landed elites from the other prominent local Sindhi tribes such as Wadero (elder, zamindar) Jalal Khan Abra from the Samma tribe. ${ }^{94}$

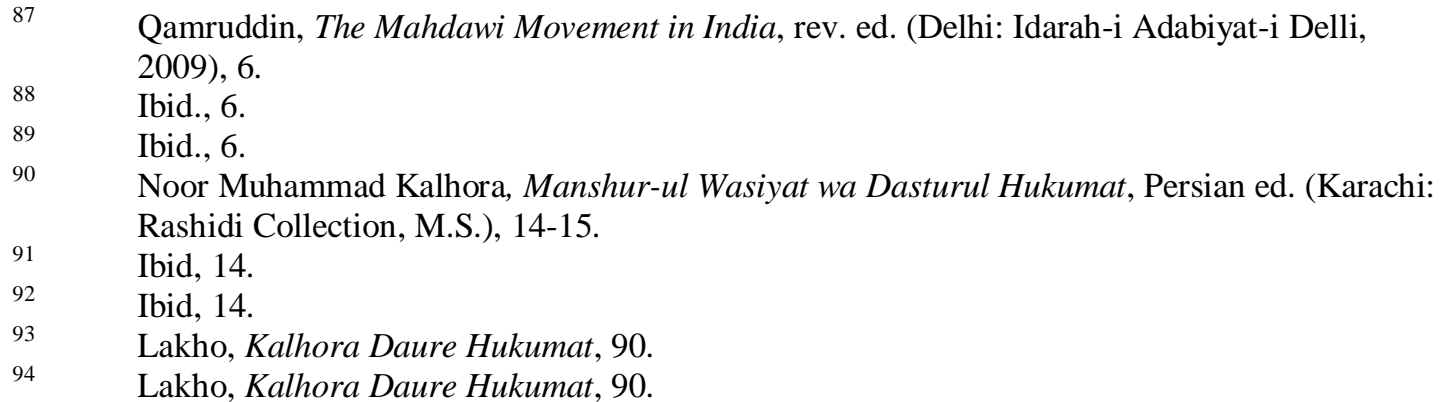


Under Ghulam Shah Kalhora, the nephew and successor of Ilyas Kalhora, the tribe seized land from the Sindhi tribes of Sanghi and Abra and brought them under cultivation. Shah Ali built the village of Kotli to which the poor people of Sindh started migrating. He also built the canals of Larkana to support agriculture. Violent conflicts over land continued during his period between the Kalhoras, Sanghi and Abra, a conflict that threatened to destabilise the Mughal administration of the region. Mian Ghulam Shah Kalhora took land from the Sanghi and Abra which enraged them. In one of the tribal fights Mian Ghulam Shah died. There are three views about why he died. According to Meer Ali Sehr Qani Thattvi, Jam Siddique and Jalal Abra the leaders from the rival tribes complained to the Nazim of Bhakkar (under the jurisdiction of the Suba of Multan) about Mian Ghulam Shah. The Nazim consequently executed Mian Ghulam Shah in 1658. The author of Lubb-i-Tarikh-iSindh however said that Ghulam Shah was killed during the tribal warfare between the Sanghi and the Abra tribes. ${ }^{95}$ Ghulam Muhammad Lakho in Sindh Dure Hukimat conclude that he was killed during the time when Emperor Aurangzeb was preoccupied with the struggle in Deccan; taking advantage of his absence someone killed Ghulam Shah. ${ }^{96}$

Ghulam Shah Kalhora was succeeded by his nephew Nasir Muhammad Kalhora (1692). His reign is divided into three phases. In the first phase the Kalhoras captured the Mughal Pargana of Chini and attacked several places near the Mughal Suba of Bhakkar and Siwistan. He also killed the Mughal gumasta (manager). Mahabat Ali, the Mughal governor of Bhakkar, and Nawab Mirza Khan, the governor of Sibi, tried to arrest Nasir Muhammad. After several unsuccessful attempts, Aurangzeb sent Prince Muhammad Muizuddin from Multan to get him. $\mathrm{He}$ was arrested and sent to Delhi in 1675, but later, fled from the prison and reached Shikarpur through Jaiselmer, Uchh and Sitpur. ${ }^{97}$

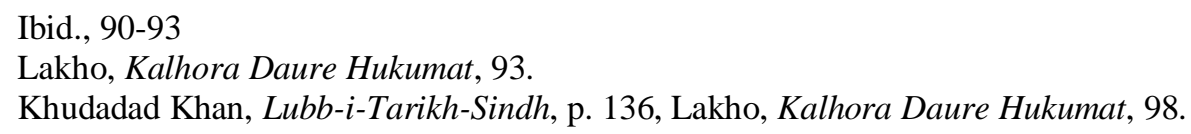


In Sikarpur, Amir Muhammad Bahadur Khan gave refuge to Nasir Muhammad Kalhora and won for him an imperial pardon. ${ }^{98}$ Ghulam Muhammad Lakho says that the Kalhora leader was imprisoned for five years, and then was pardoned by Aurangzeb for pragmatic reasons. Aurangzeb had allied with Mewar during this time and was going to Deccan when, along the way, he also allied with the Kalhoras and asked them to take care of the security of the Bolan Pass. ${ }^{99}$ The emperor also gave the administration of the pargana of Chaduka to Mian Nasir Muhammad Kalhora. From there Nasir Muhammad moved to the region inhabited by the tribe of Panwars. After subduing them he founded a town called Khari in Bhowanir district and settled there. He also assumed the title of Faqir, which meant a dervish, perhaps in order to establish himself as a religious figure and win some followers there. He also had a few dervishes like Inayat Shah Faqir and Fauja Faqir, who were living peripatetic lives, settled in Cutch. ${ }^{100}$

Nasir Muhammad Kalhora then defeated Yaqub Khan, the Governor of Bhakkar in a battle. The date and place of the battle are not mentioned in our sources, however Ghulam Muhammad Lakho says that it was during the reign of Aurangzeb. ${ }^{101}$ The governor of Siwistan gave Nasir Muhammad the pargana of Lakhawat on ijara (farming out or granting the right to collect revenue to the highest bidder). The pargana of Mangan Mura and Sahti were also taken over by Nasir Muhammad Kalhora. Under his leadership, by subduing the landed elites from the tribe of Panwars and the Afghans of Sibi and by contesting with the Mughal governor of Bhakkar, the Kalhoras succeeded in establishing their hegemony over the entire province of Bhakkar and Baluchistan. Obtaining the ijara of the pargana of Lakhawat added to their increasing power. ${ }^{102}$

Nasir Muhammad Kalhora was succeeded by Din Muhammad Kalhora in 1692. During this time the Mughal hold over Sindh further weakened because of 
Aurangzeb's preoccupation in the Deccan campaigns for almost twenty one years (starting from 1657) and the rise of the popularity of the Kalhoras, who had made considerable political gains during the time of Nasir Muhammad Kalhora. Din Muhammad seized Fatehpur from the tribe of Panwars. The chief of Panwars petitioned the emperor, who sent Mirza Khan Panni, the Haqim of Sibi to supress him. He could not succeed against Din Muhammad, and so Sheikh Jahan was sent from the court to deal with him. Sheikh Jahan was joined by the chiefs of Panwars. In the battle that ensued, Sheikh Jahan was killed and the Mughal force was defeated. ${ }^{103}$ After this setback, however, the Governor of Kalat, Qumba Khan Barohi, helped the imperial force against the Kalhoras, who were then defeated, but were later pardoned. But in spite of being subdued and pardoned by the Mughals once, Din Muhammad continued to extend his territory at the expense of the Panwars. Consequently, this time Aurangzeb sent his grandson Muizuddin, who was then the Subadar of Lahore and Multan, to subdue him. ${ }^{104}$

Din Muhammad Kalhora, intimidated by the idea of fighting against a Mughal prince, sent his emissaries to Prince Muizuddin at Bhakkar, where he was stationed, asking for a pardon. Realising that the Kalhora chief was not against the Mughal state and the Kalhoras' conflicts with the other chiefs and tribes of the region were local in character the prince pardoned him. ${ }^{105}$ At this stage, within the Kalhora community there was a difference of opinion between the Kalhora chief Din Muhammad and his commander Maksud Sarai in relation to the stance to be taken regarding the Mughals. Maksud Sarai, unlike Din Muhamad, wanted to challenge the state. He attacked and plundered the Mughal camp at Uchh. In order to completely quell the Kalhora rebellion, Muizuddin had to stay in Sehwan for six months, during which time he destroyed their town of Ghari. ${ }^{106}$ Din Muhammad Kalhora himself

\footnotetext{
103 Ibid., 105-6.

104 Ibid. 105-6.

105 Thattvi, Tuhfat-ul-Kiram, Persian ed., 105- 106.

106 Captain MacMurdo, 'The History of the Kalhora Family of Sindh, Descended from Abbas, the Uncle of Mahomed the Prophet' Journal of the Bombay Branch of Royal Asiatic Society, V.1., July 1841, 410 .
} 
avoided fighting against the Mughal prince and asked for his pardon. ${ }^{107}$ The other faction within the tribe led by Din Muhammad's brother Yar Muhammad Kalhora was unwilling to surrender to the Mughals and continued his struggle against them. ${ }^{108}$

Din Muhammad Kalhora, who had gone to Multan to surrender personally to the Mughal prince Muizuddin, was captured and executed in 1699 CE. The other Kalhora faction, under Yar Muhamad then had to flee to Kalat where he fought with the Braohis and killed Mehrab Khan, the Haqim of Kalat. Subsequently, however, he was, subdued by the Braohis, and, had to reconcile with them; his two sons Noor Muhammad Kalhora and Muhammad Khan Kalhora were handed over as hostages. Many tribesmen and women folk of the Kalhoras were also handed over to the Haqim of Kalat by Yar Muhammad Kalhora. He stayed in Kalat for two years. ${ }^{109}$

Bakhtiyar Khan, the then Haqim of Bhakkar and Siwiwstan, seized in the meantime all the land which Yar Muhammad had controlled before he was forced to flee to Kalat. ${ }^{110} \mathrm{He}$ also created trouble for and tried to oust the chiefs of the tribe of Daudputras. A brief history of the Daudputras is necessary here in order to understand the events involving the Kalhoras. The Daudputras were a sister lineage tribe of the Kalhoras and hence also traced their descent from al Abbas and were called Abbassis. They were also known as Khawneens. Burnes however, says that there were not sufficient reasons to believe this. They were weavers and warriors who led an 'erratic and restless life' before becoming the rulers of Bahawalpur. ${ }^{111}$ The Daudputra chief Bahadur Khan had obtained a rent free land grant from the governor of Bhakkar and Siwistan, Nawab Mirza Khan, during the reign of Aurangzeb, and here he founded the town of Shikarpur. ${ }^{112}$

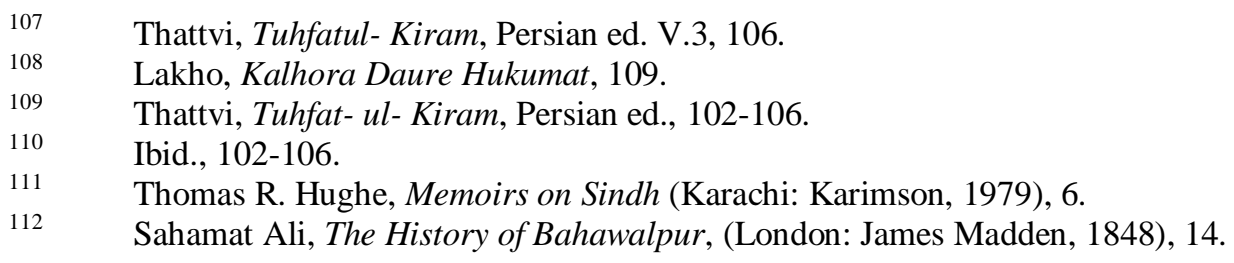


When Bakhtiyar Khan succeeded his father Mirza Khan as the new governor of Bhakkar and Siwistan, he became apprehensive of Bahadur Khan's success and changed his attitude towards the Daudputra tribe. Bahadur Khan, troubled by the lack of support from the new governor of Bhakkar, sought the intervention of their spiritual leader, the famous Sufi Pir Makhdum Gulanee of Uchh, who spoke in favour of the chief to the Mughal governor. This however had no effect on the governor, and Bahadur Khan, now fearing an attack by Bakhtiyar Khan left Shikarpur and settled in a place inhabited by the tribe of Fatteh, which was between Shikarpur and Multan. From there he proceeded to Multan, to complain to Prince Muizuddin about Bakhtiyar Khan and his atrocities. ${ }^{113}$ During this time, Bahadur Khan also helped the prince in suppressing the revolt of the Governor of Dera Ghazi Khan and in return got the royal mansab of five hundred. ${ }^{114}$

Meanwhile, Yar Muhammad Kalhora who was in Kalat was urged by his tribesmen to return to Sindh after the situation there became conducive to a comeback. He left Kalat and on his way back to Sindh seized the village of Samtani from the Panwar chiefs. ${ }^{115}$ Kalhoran forces also recaptured other lost territories and occupied regions like Markpur and Fatehpur. ${ }^{116}$ Places like Kachera, Shikarpur, Khari and Kandiyar were taken from other tribal elites. Larkana, for example, was seized from Bakhtiyar Khan the nephew of the Haqim of Bhakkar and Siwistan. ${ }^{117}$

Bakhtiyar Khan was already known for oppressing the peasants. The Daudputras of Shikarpur had complained to the Mughal prince Muizuddin in Multan about the disloyalty of Bakhtiyar Khan. Meanwhile troubled by the drive for independence and conquests of Yar Muhammad Kalhora, Bakhtiyar Khan had appealed to Muizuddin to intervene. However, when the latter took action against Yar Muhammad Kalhora, Bakhtiyar Khan, intimidated by the complaint against him by the Daudputras, withdrew his petition to the prince and asked him to return.

Ibid., 16.

Ibid., 17.

Thattvi, Tuhfat ul Kiram,V.3.Persian, 106. Ibid., 106. Ibid. 
Prince Muizuddin, however knowing that Bhaktiyar was infamous for oppressing the peasants and hearing the complaint of the Daudputras, now proceeded against him and defeated and killed him in a battle. The exact date of the battle is not mentioned in any of our sources. ${ }^{118}$

Ghazi Khan Dardoi was appointed to replace Bakhtiyar Khan, as the governor of Sibi and Dhadar (both located in the Suba of Multan). However he could not handle the administration of the region, including management of local tribal relations. For this reason Prince Muizuddin appointed Yar Muhammad Khan Kalhora the governor of Sibi and Dhadar, because he was the dominant local elite of the time and had a huge following among native Sindhis. ${ }^{119}$ In 1701 Yar Muhammad Kalhora was also given a mansabdari of five hundred, a jagir in Siwi and a laqab (title) of 'Khuda Yar Khan' (friend of God) by the Mughal prince. Because handling the administration of Sindh was now getting difficult for Mughal officials, the Mughal regime started appointing native elites to important administrative positions. For example, Meer Amiuddin was appointed as governor of Khanpur and the chief of the Daudputras was appointed the governor of Shikarpur. Siwistan was given to another local elite, Ghulam Muhammad Sukhani. ${ }^{120}$ Later the Mughals also handed over some zamindaris in Bhakkar and Siwistan to Yar Muhammad. ${ }^{121}$

But soon trouble started brewing for the Mughal state in another part of Sindh. In Miranpur the peasants tyrannised by the Mughal amalguzar (revenue collector), had become the followers of the Sufi Pir Shah Inayat (1655-1718), who belonged to the Shuhrawardi sect. Many peasants from this region, instead of paying revenue to the zamindars, started making offerings to the pir's Khanqah (hospice). Oppressed and poor peasants were flocking to this hospice, and Shah Inayat settled them on his land. He distributed the produce grown on land equitably among his followers. His increasing popularity during this period threatened other Sufi and

Ibid.

Ibid, 170.

Ibid.

Thattvi, Tuhfat-ul-Kiram, V. 2, Persian ed., 100. 
Sadat (plural of Saiyid ) from the neighbouring town of Bulri. Many of their followers were leaving them and joining Shah Inayat's sect. Independent tendencies among the peasants of the region also enraged the zamindars. In particular Noor Muhammad from the Paleja tribe, a zamindar of the pargana of Piljar, and Hamal Lakha from the Jat tribe, sided with the Sadat of Bulri against Shah Inayat and asked the Mughal subadar of Thatta, Meer Lutf Ali Khan for his support.

The Mughal Subadar, already losing control over many parts of Sindh, did not want to get further involved in the local tribal rivalries. He asked the Sadat of Balri and his supporter zamindars to settle the matter with Shah Inayat on their own. Shah Inayat's khanqah was consequently attacked and many of his followers were killed. The land seized from Shah Inayat, however, was restored to him after he complained to the Mughal Governor. Later, in 1716, Nawab Azam Khan, who succeeded Lutf Ali as Subedar of Thatta, was again approached by the Sadat of Balri and the zamindars who felt threatened by Shah Inayat. Shah Inayat's khanqah was serving as a refuge for the peasants fleeing from the oppressive demands of the Mughal amaldars, and the complaints about him convinced the new governor of Thatta that Shah Inayat's growing power was inimical to the interests of the state. The governor levied tax on his land even though previously it was considered as revenue free land by the Mughals. Also he ordered all the officials and Jagirdars under him, including Yar Muhammad Kalhora, who was governing Sibi and Ganjaba during this time, to take military action against him. A battle took place in Jhok, and Shah Inayat was killed on 1 January 1718. Governor of Thatta, Azam Khan, in return for Yar Muhammad Kalhora's contribution against Shah Inayat, gave him jagirs in Shumawati and Chahkan. Yar Muhammad also took over the parganah of Rupah on Ijarah (revenue farming agreement). Sindhi poets such as Bedil equated the killing of Shah Inayat with the martyrdom of Mansur al Hallaj, and with the deaths of Imams who sacrificed their lives while following the Sufic path. ${ }^{122}$ Annemarie Schimmel sees Shah Inayat's sect as an example of 'religious communism' as he stood against

122 C. Shackle, 'Styles and Themes in the Siraki Mystical Poetry of Sind,' in Hamida Khurro ed. Sindh Through the Centuries, rev. ed. (Karachi: OUP,1993), 252-256. 
the Sadat of Bulri. Sadat Bulri is an example of a religious leader who became a 'feudal lord' during this period. ${ }^{123}$

The execution of Shah Inayat by the Sadat, zamindars and Yar Muhammad Kalhora (although by an order from the Mughal Governor of Thatta) is evidence of the growing competition among the religious leaders for following and land in Sindh during the early eighteenth century. Oppressed peasants were depending on the Sufis or local Pirs for protection and refuge. The growing number of followers of these religious leaders including the Kalhoras, created competition between them and also with other landed elites and zamindars for resources such as land and labour. By this time, the Mughal governors too realised the complexity of the tribal and local dynamics of the Sindhi society and as noted above were appointing native elites to the administrative posts in Sindh, instead of Mughal officials from the Delhi court.

The revenue from the regions such as Bhakkar was also falling. When the chief of the Daudputras was given a jagir near Shikarpur in Bhakkar by prince Muizuddin, he was advised by him not to remit the amount of revenue settled with the peasants because the land was unable to generate that much amount. Revenue pending from these regions was Rs. 60,000 from the Rabi harvest and Rs. 40,000 was due from the Kharif. Because the land given to Yar Muhammad Kalhora in Bhakkar by the Mughals was not very fertile, the yield from it was low. To increase the productivity, Yar Muhammad constructed irrigation canals. In spite of that, crop yields were not enough to pay the tax levied on the land, and Yar Muhammad had to borrow money from the local Sahukar (moneylenders) to remit it. ${ }^{124}$

During this time Prince Muizuddin, who was the Subadar of Multan, had to face incursions and disturbance such as destruction of property and cropland from Shah Muhammad, an Afghan rebel from Kalat. Yar Muhammad sent his follower Meer Shahdad Talpur Baluch to help Muizuddin against Shah Muhammad. This service was greatly appreciated by Muizuddin and he increased Yar Muhammad's

123 Annemarie Schimmel, Islam in the Indian Subcontinent, (Leiden: E.J. Brill, 1980), 171.

124 Abdur Rauf, Guldadtan-i-Norais Bahar, MS. 34 (Karachi: Rashidi Collection, n.d.), 28. 
mansab, and he also gave the jagir of Pitbaran to Meer Shahdad Talpur. ${ }^{125}$ Muizudin also ordered the Governor of Kalat to release and send back to Multan the sons of Yar Muhammad, whom he had held as hostages. ${ }^{126}$

In Thatta, it was the local rais (landed elites) who used to maintain the law and order of the regions under them, as the Muhhal Subadar was not much concerned about it or perhaps did not have means to administer the region. On the request of the Nazim of Thatta, and with the help of his army, Yar Muhammad suppressed the tribe of Nahmardis, who plundered and raided the region of Thatta and Siwistan. ${ }^{127}$ However despite all difficulties Yar Muhammad maintained the administration of Sindh when after the death of Aurangzeb the centre was disturbed by civil wars and court intrigues. The weakness of the centre facilitated the rapid progress of the career of Yar Muhammad Kalhora in Sindh. During Muhammad Shah's time as emperor (1719-1748), the Mughal centre was too weak to aid its appointed officials in the far off provinces. Sindh was a peripheral region under the Mughals and its local dynamics and complex tribal societies made it, from the time of its conquest by Akbar in 1591, an area with pockets of virtually autonomous territories inhabited by the independent tribes outside the Mughal control. ${ }^{128}$

With Yar Muhammad controlling significant parts of the region, including the Suba of Thatta and Bhakkar Sindh now had appearance of a compact political territorial unit. This marked a significant change because it has been fragmented for so many years, the result of several small rais and zamindars engaged in fights to expand their territorial possessions. Yar Muhammad's nineteen-year leadership of the Kalhora tribe had started with the struggle against the Mughal authorities but ended with his appointment as the Mughal mansabdar and in charge of many places in Sindh. He was given the title of 'Khuda Yar Khan' by Aurangzeb. He had a force of 20,000 sawars (horsemen) and mercenaries which was comprised mainly of the

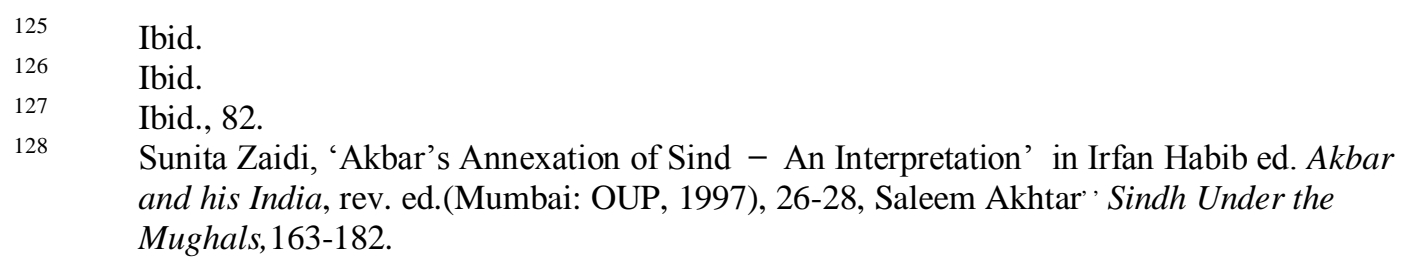


people who were from the families that had been the followers of the Kalhora dynasty, through many generations; they were called 'fuqra' (plural of 'faqir' which means a dervish). ${ }^{129}$ Yar Muhammad Kalhora though had jagirs in Sibi and Ganjaba and had land in many other places at his disposal, he towards the end of his leadership suffered from paucity of resources needed to maintain his army and guide the frontier regions of Sindh and Baluchistan including Bolan and other passes. ${ }^{130}$

Yar Muhammad Kalhora's death in 1719 was followed by a war of succession between his sons Noor Muhammad Kalhora and Daud Khan Kalhora. Noor Muhammad finally became Sajjada Nashin and assumed leadership of the tribe; his position was acknowledged by the emperor Muhammad Shah, who also gave him the title of Khuda Yar Khan. ${ }^{131}$ Noor Muhammad allied himself with the other landed elites (waderos and arbabs) of Sindh and won their loyalty. ${ }^{132}$

Noor Muhammad maintained a policy of territorial aggrandizement like his father and expanded his territories at the expense of the neighbouring tribes. In 172324 he sent Meer Shahdad Talpur to Mubarak Khan, the chief of the Daudputras to ask him to surrender Shikarpur on the ground that he was not legitimate owner and the land rightfully belonged to Meer Wase Khan, the amaldar of Khanpur and Shikarpur. ${ }^{133}$ When the Daudputra chief Mubarak Khan refused to cede the territory, his forces were attacked in Shikarpur. But the battle did not go well with Noor Muhammad, as many of his Khwaneens, (plural of Khan or soldiers of high rank) were killed. Subsequently, an alliance was sought with Mubarak Khan and a settlement divided Shikarpur into four parts; two areas were to remain with the Daudputras, one was ceded to Noor Muhammad Kalhora and the fourth went to Meer Abdul Wase Khan who, according to Noor Muhammad, was the original holder of the jagir. ${ }^{134}$

\footnotetext{
129 Ibid., 58, 59.

130 Abdur Rauf, Guldastan-i-Noras Bahar, 52.

131 Daulat Rai, Mirat-i-Daulat-i-Abbasia, 114-115.

132 Ibid.

133 Lakho, Kalhora Daure Hukumat, 123.

134 Ibid., 122-123.
} 
After six months Sadiq Muhammad, who succeeded his father Mubarak Khan as the next Daudputra Chief, was again attacked by Noor Muhammad Kalhora. Sadiq Khan now sought the intervention of his patron Sufi Saint Abdul Kadir of Uchh, who pleaded his case to the Governor of Multan, Shah Nawaz Khan. ${ }^{135} \mathrm{He}$ succeeded in securing from the Governor a grant of a jagir in the Taluka (district) of Chaudri. ${ }^{136}$ In the battle against the Daudputras, Abdullah Khan Braohi who had succeeded his father Samunder Braohi as the wali of Kalat, had allied with Noor Muhammad Kalhora. ${ }^{137}$ But, like his father Samunder Braohi, he still wanted the Kalhora chief to hand over to him the regions of Kachhi and Ganjaba, which were topographically plain regions; Kalat was a hilly place, and in winter the Kalat herdsmen needed to bring their cattle down to the plains of Kachhi and Ganjaba. ${ }^{138}$

A battle ensued between the Braohis and the Kalhoras in which the former were defeated and the end result was an alliance between the two tribes. Intermarriage helped strengthen the alliance between the Kalhoras and the Braohis; sons of Noor Muhammad Kalhora married daughters of Abdullah Khan Braohi. ${ }^{139}$ In support of the alliance between Braohis and the Kalhoras, Mughal emperor Muhammad Shah gave the laqab (title) Sabit-i-Jang (Master of War) to Noor Muhammad Kalhora and a royal mandsab of 5000. ${ }^{140}$ The next year, however, the Braohis again attacked and plundered Noor Muhammad's possession in Kachhi. The Kalhoras retaliated, did battle at Khanpur, and were victors. This time Abdullah Braohi was executed. Noor Muhammad at this stage could have occupied Kalat but he did not consider it economically profitable, for it was a hilly and uninhabitable region. $^{141}$

Munshi Abdur Rauf, the author of Guldastan-i-Noras Bahar (bouquet of fresh spring) says that Noor Muhammad Kalhora, after subduing the Braohis and

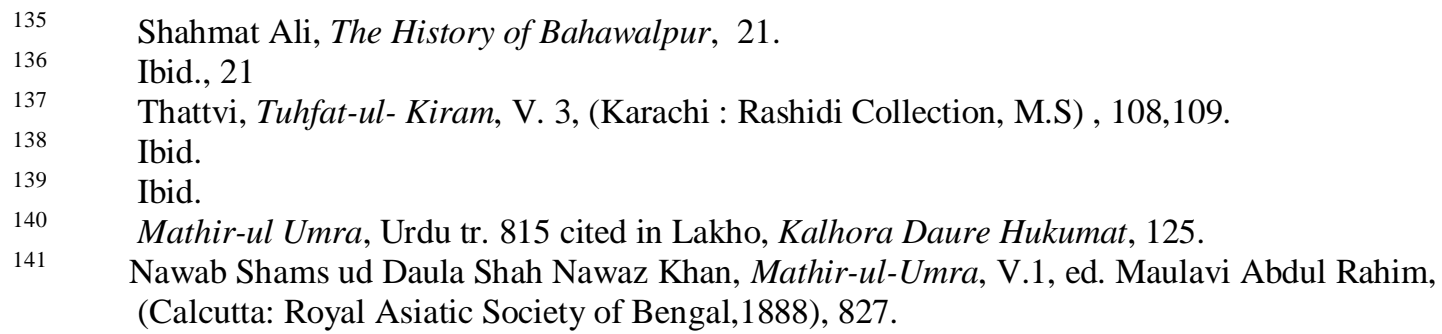


expelling the Daudputras from Shikarpur, had become the most powerful subadar of Sindh. In 1736, he was granted the Niabat (viceroyalty) of the sarkar of Siwistan and was also made the naib faujdar of the sarkar of Siwistan. ${ }^{142}$ During this time the practice of ijara had become so widespread that in 1736 the Mughal Suba of Thatta was farmed out to Sadiq Ali Khan. ${ }^{143}$ Considering that the Mughal empire was divided into twelve Subas, the farming out of an entire Suba is evidence of the declining economic condition of the state. Sadiq Ali Khan however could not pay the sum of ijara in the second year of his ijaradari and had to bear a loss. During this time a wali (representative) of Noor Muhammad was attending the imperial court. Taking advantage of the situation in Thatta and the panic generated in the court due to the arrival of the Persian Nadir Shah to Qandahar, Noor Muhammad Kalhora managed to obtain the ijara of Thatta on a sum of Rs. 3 lakh, through his representative in the Mughal court. But, before the money could be paid to the Mughal emperor Muhammad Shah, Nadir Shah attacked India and Sindh came under the Persian rule in $1739 .^{144}$

However, early in 1739 before Nadir Shah's incursion in India, Noor Muhammad Kalhora had sent his son Murad Yab Khan to manage Thatta. When he arrived there, he subdued the two independent chiefs, the Jam of Kikrala and Rana Ajmal of Dharaja from the tribe of Najamra. These chiefs exercised authority over the Indus delta. They controlled the main branches of the Indus river and levied taxes on the inland trade carried on these streams. ${ }^{145}$ To enhance the revenue through trade it was necessary to win control of this region and consequently these chiefs were subdued. $^{146}$

\footnotetext{
$142 \quad$ Abdur Rauf, Guldastan-i-Noras Bahar, 37.

143 Thattvi, Tuhfat-ul-Kiram, V.3., Persian, ed., 102.

144 Ibid., 109.

145 Ibid.

146 Ibid.
} 


\section{Conclusion}

Thus group formation among the Kalhoras was not based on kinship, which the colonial ethnographers often thought to be the main foundation of tribal identity. The Kalhoras emerged from a Sufi religious community within which the Piri-Muridi relationship between the spiritual preceptor and the disciples developed into a 'patron-client' relationship. The Kalhoras provided for their murids materially, leading to them becoming martial groups. They gained political prominence by warring with other local landed elites over resources. To increase their religious following and achieve religious legitimacy they claimed Shajra from the Prophet's uncle. This might or might not be true, but if we give weight to public memory we cannot reject the claim outright. The decline of the central power of the Mughal empire from the time of Aurangzeb's death (1707) to Nadir Shah's invasion (1739) facilitated the increasing political power of the Kalhoras.

Sindh is thus a classic case where the weakening of the centre gave rise to the fissiparous tendencies in the periphery. Given its peripheral location the control of the Mughal centre in this region was perhaps never so stringent. But then, during the lifetime of Aurangzeb, when he was involved in his Deccan campaign, the Mughal hold was getting weaker in Sindh and the locally powerful Kalhoras began to replace the Mughal mansabdars who had previously come from the Delhi court. This phase of the Kalhora's political rise under Mughal patronage started in 1701. The empowerment of the Kalhoras accelerated after the death of Aurangzeb because the Mughal court was further weakened by the war of succession among the Mughal princes. The economic decline of the Mughals in Sindh was manifested in their practice of giving land on ijara to the local elites because they were unable to collect revenue themselves. The practice of ijara in Sindh culminated in the handing over of the entire Suba of Thatta to the Kalhoras. It is strong evidence of the decline of the Mughal rule in Sindh. The Mughal Emperor however was still the fountainhead of all political legitimacy in eighteenth century India, and the Kalhoras looked for political sanctions and legitimacy from the Mughals. This changed when Nadir Shah's invasion in 1739 physically separated Sindh from Mughal India. 


\section{Chapter 2}

\section{The Kalhoras under Persian and Afghan rule}

The first half of the eighteenth century saw three major events in the Eastern worldthe collapse of the Mughal empire in India, of the Saffavid empire in Persia and of the Ottoman empire in Central Asia. M. Athar Ali sees a link between the simultaneous demise of these three empires. He judges that the Islamic world suffered from a cultural failure, leading to a divorce between the world of intellect and world of labour. This hindered the development of science in the three kingdoms and led to a shift in the world economy in favour of Europe. The cultural failure of the Mughals also prevented them from dealing with an 'agrarian crisis' and from developing modern armaments. The Mughals were still reliant on 'swords-wielding cavalry', a reason for their defeat at the hands of Nadir Shah Afshar, the Persian ruler from Afghanistan, at the battle of Karnal in $1739 .{ }^{147}$ During the phase of Mughal decline and the shift from Mughal hegemony in Sindh to Persian hegemony in 1739 and to Afghan hegemony in 1747, the English East India Company (EIC) and the Dutch Vereenigde Oostingde Compagnie (VOC) found a conducive environment in which to expand their trade in the region north-west of India. The following discussion will explore the reasons why Sindh passed from Mughal to

M.Athar Ali, 'The Passing of the Empire: The Mughal Case,' Modern Asian Studies, Vol. 9, no. 3, 1975, 390, 394. The reasons for the decline of the Mughal Empire have been debated by a number of scholars. Jadunath Sarker focusses on the religious policies of the Mughal ruler Aurangzeb (d. 1707); Irfan Habib gives primacy to the 'agrarian crisis'; Satish Chandra judges the 'Jagirdari Crisis' and failure of the Mughal mansab system to be most important;, for M.N.Pearson, the 'Deccan Crisis' was critical; in J.F. Richards' analysis, fundamental factors were Aurangzeb's 'managerial crisis', in which support of the great firms shifted from the Mughals to the nascent regional powers, the rise of powerful zamindars in the Punjab and the strengthening of the Mughal Governors in Awadh by Muzaffar Alam. See this thesis's introduction, 2-6, J.N. Sarkar, History of Aurangzeb, V. 3, (Calcutta: M.C. Sarkar and Sons, 1916), 283-364, Irfan Habib, Agrarian System of the Mughal India, 1556$1707,2^{\text {nd }}$ ed. (Bombay: Oxford University Press, 2005), 364-405; Satish Chandra, Parties and politics at the Mughal Court, 1707-1740 (Aligarh: Aligarh Muslim University,1959), xiii-xvii; P.Hardy, M.N.Pearson and J.F.Richards, 'Articles on the Decline of the Mughal Empire', Journal of Asian Studies, Vol. XXXV, no. 2, February, 1976, 221-63; Karen Leonard, 'The "Great Firm" Theory of the Decline of the Mughal Empire,' Comparative Studies in Society and History, V. 21, April, 1979, 161-7. 
Persian and Afghan rule. It will also examine the efforts of the Kalhoras to resist Persian and Afghan hegemony and to form a state of their own.

\section{The Passing of Sindh from Mughal to Persian rule}

Nadir Shah Afshar had been invading and plundering north-western regions of the Mughal empire since the 1720s and the region of Sindh came under his suzerainty in 1739. The success of Nadir Shah in India and his plunder of Delhi exposed the weakness of the Mughal empire to its neighbours, and also to the English East India Company whose previous efforts at expansion, albeit commercial, was checked by the Mughal ruler Aurangzeb (d. 1707) in the seventeenth century. The Mughal records do not mention Nadir Shah's invasion, or the damage done to the imperial capital, Delhi, by the Persians; this is because Muhammad Shah (1719-1748), the Mughal ruler of India during the invasion, had not only banned the court historians from recording the event but also dismissed them from their posts as historians. ${ }^{148}$ Our most important source for this period is Tarikh-i Jahan-kushan-i-Nadiri (history of the world slayer or conqueror) by Muhammad Mehdi Khan Atarabadi. Astarabadi was an employee of Nadir Shah and recorded his campaigns in Persia, Khurasan, Afghanistan and India. The book was completed in $1765 .{ }^{149}$

Nadir Shah had gained an influential position in the declining Saffavid empire in the 1720s-30s after establishing himself as an able military commander during a series of successful campaigns against the Gilzais, Turks, Afghans and the Russians. In 1732 he asked the Saffavid emperor Shah Tamhsap (d. 1740) to abdicate the throne in favour of his son, Abbas Mirza. Shah Tahmasp was deposed from the throne of Persia on 31 August 1732 and imprisoned. On the next day Abbas Mirza was declared the ruler of Persia.Eventually Nadir himself ascended the throne

Freeland Abbott, 'The Decline of the Mughal empire and Shah Walliullah,' The Muslim World, V. 52, no. 2, 1962, 115.

Muhammad Mehdi Khan Astarabadi, Tarikh-i-Jahan- Kushan-i-Nadiri, Amahar Abadi ed. (Tehran: Dunaiyi Kitab, 1864), 367-389. 
himself in 1737 after strengthening his support base in the Persian army. ${ }^{150}$ The invasion of India was a sequel to Nadir Shah's successful campaigns against the Galzais and the Abdalis of Afghanistan. ${ }^{151}$ His campaigns in Turkey had reached a stage of stalemate. Invasion of India was a means of replenishing his treasury for further campaigns against the Turks. As noted above, the declining state of the Mughal Empire was by this time evident to observers. ${ }^{152}$ The Mughals had already suffered a series of losses against the Marathas. Nadir Shah, during the reign of Shah Tahmasp (1722-1732), wanted to prevent the Gilzais from taking refuge in the Mughal Court. In 1730, he sent a letter on behalf of Shah Tahmasp requesting the Mughal Emperor, Muhammad Shah, to comply with this request. He also stated his desire to retake Qandahar, the control of which had been contested by the Mughals and the Saffavids in the past; at this time it was under Afghan rule. ${ }^{153}$

In 1732, when Shah Abbas III became the ruler of Persia, Nadir Shah again urged Muhammad Shah to act against the Afghans. Troubled by the Maratha incursions, Muhammad Shah decided not to act on Nadir Shar's avice. ${ }^{154}$ On 4 May 1737, before marching against the Ghilzais who ruled Qandahar, Nadir Shah sent his envoy, Muhammad Khan Turkoman, to the Mughal court with the same request. Muhammad Shah however, did not reply to the letter and, in fact, detained the Persian envoy in his court for a year. ${ }^{155}$ In Thatta, on his way back to Persia, the envoy, died. Nadir Shah had to request the Dutch trading company VOC to provide a vessel in which the envoy's possessions could be shipped home. ${ }^{156}$

Nadir Shah followed his successful campaign in Qandahar in 1737 with a march into India; he explained the march as a measure to curb Afghan inroads into

Satish Chandra, Parties and Politics at the Mughal Court, 1707-1740, 2d ed. (New Delhi: People's Pub. House, 1972), 244, Laurence Lockhart., Nadir Shah: A Critical Study Based Mainly Upon Contemporary Sources, (London: Luzac \& Co, 1938), 62.

Lockhart., Nadir Shah: A Critical Study, 247.

Ibid.

Jadunath Sarkar, Nadir Shah in India, (Patna: Patna University, 1925), 16.

Chandra, Parties and Politics, 248.

Sarakar, Nadir Shah in India, 16, 17.

William Floor, The Dutch East India Company (VOC) and Diewal- Sind (Pakistan): in the $17^{\text {th }}$ and $18^{\text {th }}$ Centuries (Karachi : Institute of Central \& West Asian Studies, 1993-4), 49. 
north-west India and, therefore, essential for the security of both India and Persia. ${ }^{157}$ According to Jadunath Sarkar it was the 'defencelessness of Afghanistan' which 'brought Nadir Shah to India.' 158 There is also a view that Nadir Shah was invited by Nizam-ul-Mulk, the Mughal Governor of Deccan, and Sadat Khan, the Governor of Awadh, to invade India. This is indication of the way in which internal political strife in the Mughal centre made the regime vulnerable to attack by its rivals. ${ }^{159}$

The security of the north-west frontier had always been a concern for the Mughal regime, but the later emperors, preoccupied with pressing local issues, had neglected it. The Afghan menace in the Qandahar and Turan regions was well acknowledged by Muhammad Shah. At the request of Nadir Shah, he instructed the subedar of Kabul and Sindh to keep a check on the Afghans, but he was also maintaining an alliance with Mir Wais, the usurper of Qandahar and plunderer of Multan. ${ }^{160}$ According to Riazul Islam, it was the failure of Mughal diplomacy during Muhammad Shah's reign which was responsible for the worsening of its relations with Persia. ${ }^{161}$

As argued by Satish Chandra, Muhammad Shah was burdened with the difficulty of handling the various political factions in his court at a time when the Mughal Empire was declining. ${ }^{162}$ And so, unlike the great Mughals of the past, the later Mughals were unable to maintain effective diplomatic relations with the powers along its north-west frontier. This neglect of the north-west frontier policy and Nadir Shah's subsequent success in India can be connected to the factionalism within the Mughal court; the court had become a house of intrigues within which the Turanian, Iranian and Hindustani factions of the Mughal Umra (governing class, plural of amir) competed with each other. Muhammad Shah inherited an empire that was declining and a court that was disintegrating, a process that had started towards the end of

\footnotetext{
157 Chandra, Parties and Politics, 248.

158 Jadunath Sarkar, Nadir Shah in India, 10.

159 Lockhart, Nadir Shah: a critical study, 124

160 Sarkar, Nadir Shah in India, 16, Lockhart, Nadir Shah: a Critical Study, 24.

161 Riazul Islam, Indo-Persian Relations: A Study of the Political and Diplomatic Relations

162 between the Mughal Empire and Iran (Tehran: Iran Culture Foundation, 1970), 145. Chandra, Parties and Politics, 242-246.
} 
Aurangzeb's reign (1658-1707). Muhammad Shah himself, famous as 'the asylum of negligence', could not do much to check the on-going struggle for the position of Wizarat (ruling elites or nobles) in the Mughal court at that time. ${ }^{163}$ The real power in the court was wielded by the wazir Nizam ul-Mulk. ${ }^{164}$ The Subedar of Awadh, Sadat Khan Burhan-ul-Mulk, was a prominent provincial governor and an influential Mughal Umra. He was an Irani amir from Khurasan, and was notorious for favouring the Persian component of the Mughal Umra. ${ }^{165}$

After Qandahar was conquered by Nadir Shah in 1737, the Afghans infiltrated Mughal-controlled territory in Afghanistan near Ghanizi and Kabul. Despite a request from Nadir Shah, Muhammad Shah could not put a stop to this as the Mughal border in the north-west at the time was not well enough defended, to prevent the Afghans from pushing into the region. ${ }^{166}$ The Mughal Governor of Kabul had asked Delhi for military and financial support to deal with the Afghan menace, but in vain. ${ }^{167}$ In 1737 the Mughal soldiers had not been paid for five years, which is testimony to the financial decline of the Mughal Empire. ${ }^{168}$ Because he was unable to defend the Mughal north-west frontier, the Mughal Governor of Kabul lived in Peshawar. ${ }^{169}$ After the Persian siege of Qandahar, Nadir Shah attacked the Mughal Suba of Kabul. The Mughal court, divided by ethnic rivalries and conflict, could not help the governor of Kabul when he asked for help. ${ }^{170}$

While Muhammad Shah was neglecting the defence of India's north-west border, we see Noor Muhammad Kalhora taking defensive measures by trying to maintain diplomatic relations with Nadir Shah. The Kalhora leaders expected that Nadir Shah's planned invasion of India would bring his forces through Sindh, and Noor Muhammad Kalhora had been writing to him regularly. The letters' purpose

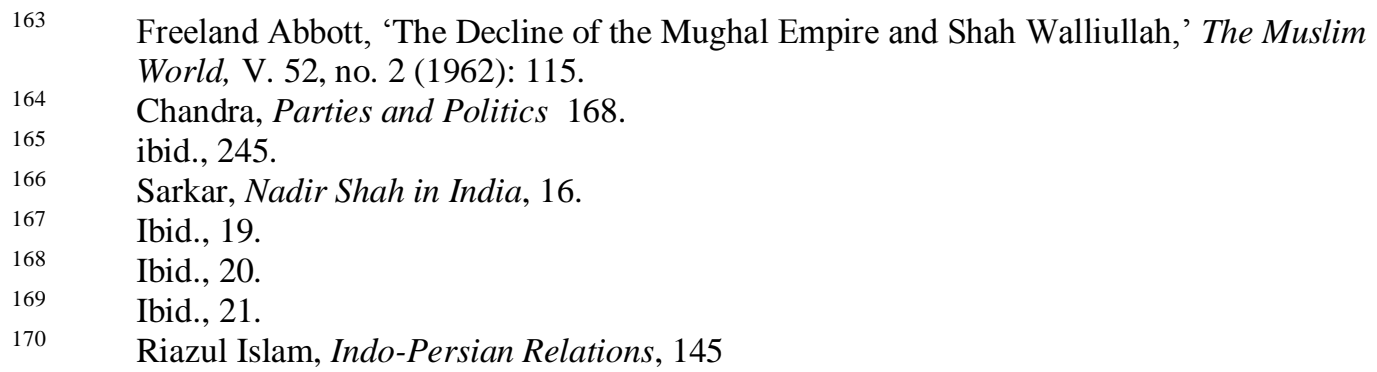


was, through flattery, to protect Sindh. After Nadir Shah subjugated Qandahar in 1738, Noor Muhammad Kalhora even went to Larkana in Upper Sindh to protect Sindh's border there. ${ }^{171}$ Nadir Shah started his campaign against northern Afghanistan in May 1738. Ghazni was easily subdued as the Mughal Governor of Ghazni, Baqi Khan, unable to defend the city, had fled. Kabul was therefore Nadir Shah's next target. ${ }^{172}$

In July 1738, after a siege of seven days, Kabul fell to the Persians. Nasir Khan, the Mughal Governor of Kabul, offered resistance with his ill-equipped army of ill-fed soldiers, but was soon defeated and arrested. At Kabul Nadir Shah received an arida (letter) from his envoy Muhammad Ali, whom he had sent to the court of Muhammad Shah, stating that the emperor was neither replying to his request nor letting him depart from the court. ${ }^{173}$ The Mughal ruler's undiplomatic response provoked Nadir Shah to go further with his campaigns in India. ${ }^{174}$ Also, Persia's campaigns against Turkey, Qandahar and Kabul had been costly, and a campaign against Delhi would be a means of replenishing Nadir's treasure chest. ${ }^{175}$

The Mughal Governor of the Punjab and Multan, Zakariya Khan, was a Turani and aspired to a position in the Mughal Court. The Umra's Turani faction was weak at this time; the Hindustani faction was dominant and prevented any rival applicant from taking a place at court. ${ }^{176}$ The Hindustani faction also stopped any government aid reaching the Punjab, even in the face of an invasion by Nadir Shah. ${ }^{177}$ Because Kabul and the Punjab were relatively defenceless in the late 1730s, Nadir Shah was more easily able to advance his campaign in India.

On 6 November 1938, Nadir set out from Kabul and proceeded toward India through Jalalabad. Peshawar was taken without resistance on 18 November. The next

\footnotetext{
171 James McMurdo, 'The History of the Kalhora Family of Sindh, Descended from Addas, the Uncle of Muhammad the Prophet, and Commonly called Abbasides', The Journal of the Bombay Branch of the Royal Asiatic Society, V. 1, July 1841-July 1843, 416.

172 Sarkar, Nadir Shah in India, 22.

173 Riazul Islam, Indo-Persian Relations, 145.

Ibid., 146.

Lockhart, Nadir Shah: A Critical Study, 219-237.

Sarkar, Nadir Shah in India, 21.

Ibid, 21.
} 
target, Lahore, was governed at the time by Zakariya Khan and also received no support from the centre. Although the zamindars of Adinagar (near Lahore in the Punjab) helped him in his struggle against the Persian army, Zakariya Khan soon realised the futility of resisting such a strong army and surrendered to Nadir Shah. ${ }^{178}$ He also had to pay to Nadir Shah a sum of 20 lakhs of Rupees; this payment was demanded by Nadir Shah in return for his sparing Lahore from plunder and restoring Zakariya Khan to his position as governor of Lahore. ${ }^{179}$ Nasir Khan, the former Governor of Kabul and Peshawar, was also restored to his previous position. ${ }^{180}$

Finally, after the success of the Persians at Lahore, Muhammad Shah became alert to the danger that the Mughal regime faced. The various factions in the Mughal court, however, were still pre-occupied with cross-factional skirmishes and manoeverings. The Hindustani faction and Khan Dauran, the Mughal Bakshi (head of the military department), succeeded in turning Muhammad Shah against Nizamul-Mulk, an experienced and able amir who was then the waqil (regent) of the Mughal court. ${ }^{181}$ This had consequences for the preparations being made for Mughal action against Nadir Shah; Nizam-ul-Mulk was not given the authoritative position that the situation demanded. Khan Dauran wanted to give his protégé, Sawai Jai Singh, a significant role in the preparations against the Persians. That the Rajputs were alienated from the Mughals at this time compounded Muhammad Shah's difficulties. He resorted to seeking help from Peshwa Baji Rao (Maratha Prime Minister), but the Peshwa was reluctant to cooperate. ${ }^{182}$

Muhammad Shah led his forces to Karnal to face the Persian invader, and was defeated in the Battle of Karnal on 24 February 1738. The treaty of Shalimar, signed by the Mughal Emperor and Nadir Shah ceded the region east of the Indus to Persia. Nadir Shah left Delhi in May 1739. Before proceeding to Bhakkar, he learned that a waqil of Noor Muhammad Kalhora, named Mir Matra, was present in the court

Ibid., 27.

Riazul Islam, Indo-Persian Relations, 147.

Sarkar, Nadir Shah in India, 28.

Ibid., 31.

Ibid., 31-32. 
of Delhi. He sent a message to Mir Matra through his envoy Muhammad Ali to ask the Kalhora ruler to agree to pay him a yearly kharaj (tribute or capitation tax) of Rs. 10,000 and to send his sons as hostages (yarghmal) to Persia; in return, Nadir Shah would allow Noor Muhammad to retain his position as ruler in Sindh. Noor Muhammad turned down this offer. Nadir Shah then advanced on Sindh. Noor Muhammad fled to Umerkot, a region in eastern Sindh. To chase him, Nadir had to proceed through Shahdadpur, where the Machis tribes put up a resistance. The Machis forces were nine hundred in number, and although they attacked Nadir Shah's army, they could not stop it. When Nadir Shah reached Umerkot he sent a message to Noor Muhammad, demanding him to acknowledge Persian sovereignty. ${ }^{183}$ Noor Muhammad was not willing to do this and decided to leave Umerkot. Nadir Shah surrounded the fort of Umerkot before Noor Muhammad could make his escape. The latter then surrendered and a treaty was signed between them; it brought Sindh under Persian suzerainty. ${ }^{184}$

Following the treaty with Noor Muhammad Kalhora and having gained regions west of the Indus from Muhammad Shah, Nadir Shah decided that, although India was rich in resources, it was not where he wanted to live. ${ }^{185}$ With the wealth obtained from plundering northern India, he decided to return and continue with his campaigns in Turkey. After replenishing his treasure chest, he sent embassies to Rome and Russia carrying messages of good will and elaborate gifts to the foreign rulers; the gifts included cash of 12,000 Nadiri Toman. ${ }^{186}$ But the Persian campaign in India had changed in many ways the entire dynamics of central Asian politics. Anticipating Nadir Shah's departure from the region, Ilbarz Khan, the governor of Khwarizm, made plans to invade Khurasan. Nadir Shah sent an army to subdue Ilbarz Khan. He also dealt harshly with the Afghans, whom he despised (and who

Bagh Ali Mutklas be Khaif, Name Naghaz, MS., Sindhi Adabi Board, Karachi, pp. 120-130. Ghulam Muhammad Lakho, Kalhora Daure Hukumat (Reign during the times of Kalhoras), (Karachi: Anjuman Ethad Ebasea, 2004), 121. Astarabadi, Tarikh-i Jahan Kusha-i Nadiri, 368. Ibid., 369-370. 
were known to describe him as 'wild and evil'); some were massacred by his army, and a few were brought into his service. ${ }^{187}$

Nadir had to march through Khyber and Jalalabad to Kabul to subdue the Afghans there. The local chiefs and village headmen were asked to submit to Nadir Shah in exchange for retaining their customary privileges. ${ }^{188}$ From Kabul, in 1742, Nadir again marched towards India, and this time captured Larkana in Sindh. He divided Sindh into three parts; Shikarpur was given to the Daudputras, Siwi to the Braohi Pathans of Kalat, and the rest of Sindh to Noor Muhammad. ${ }^{189}$ Siwi (a region of Sindh close to Baluchistan) was given to Kalat because the Kalhoras had killed the chief of Kelat, and the chief's wife had asked Nadir Shah to punish the Kalhoras. When securing Sindh, Nadir put Noor Muhammad at the mercy of Muhammad Khan, the chief of Kalat, and with the mandate to avenge the Kalat chief's death. Muhammad Khan, however, followed the traditional tribal practice of compensating the loss of life with a monetary payment and spared him. ${ }^{190}$

Zakariya Khan, the Mughal governor of the Punjab and Multan at the time of Nadir Shah's invasion, was absorbed into the Persian regime as governor of the region spanning the river Attock; he had previously been given charge of this region by Muhammad Shah. ${ }^{191}$ He was also given the title of Shah Nawaz Khan. With Sindh under the Persian rule now, Nadir Shah bestowed the title of Shah Kuli Khan on Noor Muhammad Kalhora. Under the Persian state, the collection of revenue in Sindh was easier and more regular than it had been when the region had been ruled from Delhi. Although on the periphery of the Persian empire, Sindh could be accessed from Persia through Qandahar and the Bolan Pass; access was therefore easier and more direct than it had been for the Mughal rulers. Paying a yearly Kharaj of Rs. 20 lakhs was economically draining for Sindh, and to ensure its regular payment, Nadir Shah took away with him three of Noor Muhammad Kalhora's sons

\footnotetext{
$187 \quad$ Ibid., 370, 371.

188 Ibid., 371.

189 Ghulam Rasul Mehar, Tarikh-i Sindh, V. 2. Urdu ed. (Karachi: Sindhi Adabi Board, 1908), 449.

190 Lakho, Kalhora Daure Hukumat, 128.

191 Mehar, Tarikh-i-Sindh, V. 2, 453.
} 
as hostages (yarghmal). To ensure the loyalty of Sindh, Nadir Shah demanded that Noor Muhammad recruit and equip a regular army of Sindhis, and to send it to Persia under the command of one of his sons. ${ }^{192}$ Nadir carried with him books from Noor Muhammad Kalhora's library which included risala of the Shuhrawardi and other sufi pirs. He also appointed his own official in Sindh, Sulaiman Beg Aslam, to ensure that Khutba was read in his name and that coins carrying his image were struck there. ${ }^{193}$ Nadir Shah appointed Aqa Muhammad Karim Ishfahani to the post of Wakil-i-Riyaya (administrative representative) and was given the title of Amin-ulMulk. ${ }^{194}$

To facilitate the new administrative arrangements, Noor Muhammad himself made new appointments. For example, a local chief, Sultan Samitiyo, was appointed governor of Thatta. ${ }^{195}$ As a consequence, a dual system of administration emerged in Sindh, making it difficult for Noor Muhammad to administer the region properly. Nadir Shah added to the difficulties by sending his officials to find soldiers who went missing in Sindh during his invasion of the region. With Persian officials roaming around Sindh in search of lost soldiers, the management of Sindh was further hindered. ${ }^{196}$

Another consequence of Nadir Shah's invasion was that it stoked ambitions of autonomy and independence among some tribal chiefs and tribespeople in Sindh. For example, the Baluchi Shuhra tribe of the Miyani region rebelled against the Kalhora state. The evidence of rebelliousness increased after 1739. The chiefs of the Chachkan tribe, and leaders from the tribes of Tamachi, Toghachi, Jhara, Sula, Kista and Sumrah also rebelled and stopped paying taxes at various times. ${ }^{197}$ The Nazim (governor) of Thatta, Sultan Samatiyo, was given the special task of subduing the

\footnotetext{
192 Mehar, Tarikh-i Sindh, V. 2, 518.

193 Mehar, Tarikh-i Sindh, V. 2, 467.

194 Lakho, Kalhora Daure Hukumat, 130.

195 Mir Ali Sher Qani, Tuhfat ul Kiram, V.3, Persian ed. (Karachi: Rashidi Collection, M.S.)., 110 .

196 ibid., 110.

197 James McMurdo, 'The History of the Kalhora family of Sindh, descending from Abbas, the Uncle of Mahomed the Prophet, and Commonly Called Abbasides', The Journal of the Bombay Branch of the Royal Asiatic Society, V.1, July 1841July 1844, 417.
} 
rebel tribes. ${ }^{198}$ Clearly, Noor Muhammad had to be constantly on his guard and alert to any signs of rebelliousness among Sindh's tribal people. ${ }^{199}$

Nadir Shah's invasion and the subsequent imposition of yearly kharaj destroyed the Sindh economy under Noor Muhammad Kalhora's administration after 1739. ${ }^{200}$ Under the Mughals there had been less regular collections of revenue in Sindh. With Qanahahr now under Persian rule, Nadir Shah's revenue collectors easily reached Sindh through the Bolan Pass. Noor Muhammad was allowed to continue as Sindh's ruler, but Nadir Shah's officers were responsible for ensuring that the annual tribute reached Persia. Suhail Zaheer Lari suggests that the reason why Noor Muhammad shifted his capital eastward from Khudabad to the more fertile Muhammadabad was in order to collect taxes more efficiently. Because Khudabad was situated near the rocky terrain of the Baluchistan region, the area did not lend itself to an intensification of farming that could increase the tax take. Lari says that, to rebuild the state's finances, Noor Muhammad levied taxes on 'Hindu' chiefs and enslaved them when they could not pay the money that they owed. ${ }^{201}$ In Sindh, however, the Hindus tended to be engaged in trade and commerce while the majority of Muslims were in the agricultural sector. The Hindus, who had gained significant positions in the Kalhoran administration, were involved in the manoeverings.

Noor Muhammad Khan may have levied taxes on those who were not his followers, but to say that he discriminated against the 'Hindus' or Indic community might not be factually accurate. Nonetheless, his rigorous revenue collection strained the relationship between Noor Muhammad and the tribal chiefs. Shuhra tribal chiefs from the Chakar Hala Taluka (district) mobilised their tribesmen to offer stiff resistance to Noor Muhammad. Various chiefs of the Chachkan region also rebelled, refusing to pay the taxes levied on them. ${ }^{202}$ In addition to the local discontent,

\footnotetext{
198 Mehar, Tarikh-i Sindh, V. 2., 417.

199 Qani, Tuhfat ul Kiram, V.3, Persian ed. 110.

200 Ibid., 55.

201 Suhail Zaheer Lari, A History of Sindh, (Karachi: Oxford University Press, 1994), 146.

202 Mehar, Tarikh-i Sindh, V. 2, 470.
} 
mutual mistrust existed between the Persian officials in Sindh and Noor Muhammad Kalhora. He was unsettled by the fact that Shikarpur had been handed over to the Daudputras; rivalries had long existed between the neighbouring states of Kalhoras and Daudputras . ${ }^{203}$

Since becoming subject to Persian control, the Daudputra chief, Amri Sadiq Muhammad Khan, sent his agent Shekh Sadiq to the court of Nadir Shah. Later, having dmonstrated talent in statecraft, Sheikh was absorbed in the Persian court as an official. He was then sent by Nadir Shah to investigate the activities of the Daudputra rulers. He was subsequently also appointed by Nadir Shah to collect revenue in Bhakkar in Sindh. ${ }^{204}$ According to Ghulam Muhammad Lakho, relations between the Daudputra ruler Amir Sadiq and Sheikh Sadiq started to deteriorate during this period, and Sheikh Sadiq was killed. ${ }^{205}$ Jawahir-i- Abbasia however mentions another reason for the murder. It records that before proceeding to Bhakkar, Sheikh Sadiq and the Persian officials who accompanied him were murdered by certain Daudputran zamindars, who did not like his high-handed tax collection methods. Our sources do not mention the date for the murder of Sheikh Sadiq except for the fact that this incident happened in the reign of Noor Muhammad Kalhora. Amir Sadiq Muhammad, aware of the fact that this would invite the wrath of Nadir Shah, investigated the incident and executed the assassins. In spite of that punishment, however, in 1745 Nadir Shah sent Tahmasp Khan Jalayar to Shikarpur to seek revenge for the murder of his officials. ${ }^{206}$

The murders and the arrival of Nadir Shah's investigator in Shikarpur, just beyond Sindh's northern border, worsened the situation in Sindh. Noor Muhammad, who mistrusted the Persian invader, believed that he too would be harmed, and he fled Thatta to a secure place some distance away. With the abandonment of Thatta in 1745 there was no one there to rule Sindh directly. The chaos that ensued can only

Mehar, Tarikh-i Sindh, 472.

Lakho, Kalhora Daure Hukumat, 131-133.

Ibid., 131.

Seikh Muhammad Aazam, Jawahir-i Abbasia, (Karachi: Sindhi Adabi Board, M.S.), 126. 
be imagined. ${ }^{207}$ Ultimately, Noor Muhammad had to surrender to Nadir Shah. And to win his trust again he had to send his third son, Attar Khan, as hostage to Persia. ${ }^{208}$

Meanwhile the zamindars and the local chiefs of the various small riyasat (territories) in Sindh had become autonomous, a result of the decline of the Mughal state. Noor Muhammad had been given the governorship of Thatta by the Mughals in 1737, but Nadir Shah's invasion in 1738 - 39 prevented him from quickly subduing the local chiefs. After things were settled with Nadir Shah, Noor Muhammad was able to assert his authority over autonomous chiefs such as the Wali of Dharaja and the Rajputs of the Jhokia clan. ${ }^{209}$

Nadir Shah also defeated the Daudputras in Shikarpur in $1739 .{ }^{210}$ According to one account, when Amir Sadiq explained to Nadir Shah the circumstances leading to Sheikh Sadiq's murder, all his jagirs were restored to him. According to Ghulam Muhammad Lakho, however, Nadir Shah, after listening to Amir Sadiq's story, sent Mirza Askar Ali to go to Shikarpur with him to resolve the issue. But when they reached Shikarpur they could not improve the situation there. This led to a fight between both, and Amir Sadiq was killed on 27 March 1745. ${ }^{211}$

Then, in 1747, Nadir Shah himself was assassinated. His nephew Ibrahim was now claimant to the throne, because Nadir Shah's two sons had pre-deceased him. Two of Noor Muhammad Kalhora's sons, who were there in Persia as hostages, decided that one of them should return to Sindh. This could be because they were aspiring for the rule of Sindh. Murad Yab Khan Kalhora, with a few men from Tehran including a Kalhora named Amir Shaikh Ghulam Muhammad, set off for Sindh via Musqat. Noor Muhammad's other two sons, Ghulam Muhammad and Attar Khan, remained in Persia and supported Nadir Shah's nephew in his claim to the throne over Nadir Shah's grandson Shahrukh. ${ }^{212}$

\footnotetext{
207 Mehar, Tarikh-i Sindh, V.2, 482.

208 Ibid., 482.

209 Ibid., 493-94.

210 Ibid., 483.

$211 \quad$ Lakho, Kalhora Daure Hukumat, 131.

212 Mehar, Tarikh-i-Sindh, V. 2, 519.
} 
Back in Sindh, Kalhoran chief Noor Muhammad continued as head of government and, in 1750, appointed Muhammad Khurasani as Nazim of Thatta. When Noor Muhammad's son, Murad Yab, reached Muscat, intending to sail from there to Sindh, one of his companions, Amir Shaikh Ghulam of Sindh, died. When Noor Muhammad came to know of this, he sent Shaikh Ghulam's brother, Shaik Shukrullah, to bring Murad Yab home. Murad Yab and Shaikh Shukrullah left Muscat for Sindh, but on the way Shaikh Shukrullah also died. Shaikh Ghulam and Shaikh Shukrullah were from a famous Shia Shaikh family and with their death this lineage disappeared completely from Sindh. This incident also tells about the close connections between the Kalhoras and the Shia Shaikhs. The death of the Shaikh brothers had a strong impact on the deeply religious Shia community and was lamented by the poet Muhammad Pannah Reja, who compared their death with that of Caliph Ali's sons, Hasan and Hussain. When Murad Yab returned to Sindh, both the Daftar (record or register) and Wizarat were handed over to him. Before that, during Nadir Shah's lifetime the duties of Wizarat were carried out by Diwan Giddu Mal in the Persian Court. Diwan Giddu Mal was a Hindu but also followed the Shurawardi Sufi silsila (order). ${ }^{213}$ Thus it can be argued that, after Nadir Shah's death, the Kalhoras wielded more power in Sindh than did the Persians. From this time, therefore, the Kalhora dynasty ruled independently of Persia to a significant extent.

The above discussion has aimed to show that the Persian invasion of India happened because of the decline of the Mughal regime in the early $18^{\text {th }}$ century, and especially during the rule of Muhammad Shah. The weakness of the Mughals, their failure to support their governors at Kabul and Lahore, internal strife at the Mughal court and their ill equipped army facilitated Nadir Shah's success against them. Mughals survived the jolt caused by Nadir Shah's plundering raids and conquest in 1739, but their territorial possessions were reduced with the relinquishing of regions east of the Indus to Nadir Shah. Although now independent, the 'successor states' 
that had broken with Delhi still acknowledged the Mughals as the symbolic head of state; this was true for successor states such as Awadh, Bengal and Hyderabad. With the loss of its far-flung western wing to the Persians, however, the Mughal empire suffered further economic loss when the province of Thatta was given on ijara terms to Noor Muhammad; this meant that it could no longer draw tax revenue from Thatta. After 1739 Noor Muhammad governed Sindh as a semi-independent ruler within the Persian empire, but he continued the Mughal system of administration. Nadir Shah, however, appointed his own officials to Sindh, so a dual system of administration prevailed there- one Mughal and the other Persian; this led to confusion and state malfunctioning. Several rebellions by various tribes are evidence of malfunction. Noor Muhammad handled the rebellions effectively, but before he could firmly establish a stable administration, the Afghan adventurer Ahmad Shah Abdali invaded India. As a consequence, Noor Muhammad had to learn to live under a new overlord.

\section{Sindh: From Persian to Afghan suzerainty}

Nadir Shah Afshar was infamous for his oppressive rule and exaction of excessive taxes from his subjects. Consequently his rule saw many rebellions in Persia. In Khurasan in 1747, the Kurdish people rebelled against him and Nadir Shah went there to to put down the rebellion. While he was in Khurasan, his own commanders, resentful of his cruel temperament and high-handed rule, assassinated him on 20 June $1747 .{ }^{214}$ Anarchy prevailed in Persia following Nadir Shah's death and, taking advantage of that on 20 July 1747, Ahmad Shah Abdali, an Afghani commander in the Persian army, declared himself the independent ruler of the eastern part of Persia, the area that comprises modern Afghanistan. He then claimed all the possessions east of Persia that were held by Nadir Shah and, subsequently, by Adil Shah. The territory he claimed included Baluchistan and Sindh. ${ }^{215}$

Elton L. Daniel, The History of Iran, $2^{\text {nd }}$ ed. (California: The Greenwood Histories of Modern Nation, 2012), 83.

215 Secret and Political Department, 1802, Diary no. 133 (2), Maharashtra State Archives [hereafter MSA], Mehar, Tarikh-i Sindh, V.2, 509. 
Ahmad Shah Abdali now gave Noor Muhammad Kalhora the title of Shah Nawaz Khan and claimed yearly tribute from him. Before Noor Muhammad could send the tribute, however, Abdali invaded India through the Khyber Pass. Multan and Lahore, at this time were under Shah Nawaz Khan the son of the previous Mughal Governor Zakariya Khan. He allied with Abdali but changed his allegiance later when his maternal uncle, Qammruddin Khan, who was a minister in Delhi at this time, advised him to support the Mughals. Shah Nawaz Khan, the governor of Multan and Lahore then put up a resistance against Abdali but, defeated in the battle, he fled to Delhi. Abdali then proceeded towards Delhi. The Mughals and the Afghans met on the battle field at Malupur near Sirhind. Abdali was defeated in the battle and returned to Qandahar. ${ }^{216}$

The Mughal Amir Qamruddin died on the battle against Abdali. His maternal grandnephew Shah Nawaz, the previous governor of Multan, had already been defeated by Abdali. So his son, Nawab Muinul Mulk, was now made the governor of Lahore and Multan. ${ }^{217}$ The defeat of Abdali made the Kalhora ruler reluctant to pay the tribute to Afghanistan. ${ }^{218}$ Muhammad Shah, the Mughal ruler, died in 1748 and his son, Ahmed Shah (1748-54), succeeded him. The new ruler was not much interested in state affairs. This is why his mother, Udham Bai, originally a dancing girl in the Mughal court, came to wield the real power, which she did with the help of a eunuch named Javeed Khan. Udham Bai also assumed the title of Nawab Quddusia. She had little knowledge of state and the deteriorating condition of the Mughal state invited Abdali again to invade India. ${ }^{219}$

Abdali marched to Delhi in 1749. When he reached the border of Multan this time, governor Moin-ul Mulk received no help from Delhi and he had to negotiate peace with Abdali on disadvantageous terms. He was forced to hand over the regions of Sialkot, Peshawar and Aurangabad. ${ }^{220}$ Abdali returned to Kabul with these gains 
under his belt. In 1752, the Afghan leader made a third attack on India. Moinul Mulk tried to challenge him in Shahdra, but to little effect; Abdali passed through Shahdra, reached Shalimar and encircled Lahore. After a siege of four months, Moin-ul Mulk's naib (deputy) Kura Mal died in the battle field and Moinul Mulk had to again sue for peace. Abdali negotiated an alliance with Moin-ul Mulk that allowed the latter to rule with a new title, Rustam-i-Hind, which Abdali now bestowed on him. Abdali then proceeded towards Delhi; ${ }^{221}$ there Ahmad Shah, the Mughal ruler, ceded to him territories on the western side of river Sutluj; these included parts of the then Kashmir, Punjab and Multan regions. ${ }^{222}$

With parts of Lahore, Multan, Kashmir and Sindh under the Afghans (places to the west of the river Sutluj were ceded to him, not the entire regions of Punjab and Kashmir), Ahmad Shah Abdali returned to Afghanistan. Moin-ul Mulk died in 1753 and his son Mir Momin succeeded him. A very volatile situation now came to prevail in Punjab. Mir Momin died soon after succeeding his father. The Mughal Umra Ummadul Mulk tried to win back the Punjab for the Mughals. Abdali then made another incursion into India and plundered Punjab and Delhi. Abdali, after consolidating his gains from his plunders and conquests in India, asked Noor Muhammad Kalhora to pay his overdue Kharaj; the Kalhora chief had promised to pay this when acknowledging Afghan suzerainty. Noor Muhammad's impulsive reaction to Abdali's demand was to flee to the desert region east of Sindh, on the border of Umerkot, where he died in $1755{ }^{223}$

Noor Muhammad's rule seems to be a very tragic period for Sindh because the kingdom was ravaged by Nadir Shah in 1740 and by Ahmad Shah Abdali in 1748. Noor Muhammad had to coerce Sindh's tribal chiefs to meet the demands for tribute from Nadir Shah and then from Abdali, leading to many tribal rebellions during his reign. While he was in Umerkot he sent Diwan Gidumal, who was now his finance minister and administrator, to negotiate with Ahmad Shah Abdali, but Diwan Gidumal failed to win any concessions. Diwan Giddu Mal wielded immense 
political influence before Noor Muhammad's death. and he later became instrumental in winning the throne of Sindh for Noor Muhammad's eldest son, Mian Murad Yab Khan, at a time when a struggle for succession erupted among the sons of Noor Muhammad; these sons are famously called 'the later Kalhoras. ${ }^{224}$

\section{The later Kalhora phase}

After the death of Noor Muhammad in 1754, the Kalhora's rule in Sindh was disrupted by a bitter conflict between his three sons over succession to the throne. The eldest son, Mian Murad Yab Khan, and his brothers Ghulam Shah and Atar Khan, had been taken to Persia as hostages by Nadir Shah in 1739. In 1753, after spending two years in Muscat, Mian Murad Yab Khan returned to Sindh. After Noor Muhammad's death, the chiefs of Sindh asked Ahmad Shah Abdali to give his backing to Murad Yab's claim to be Sindh's next ruler. The second brother, Ghulam Shah, was also an aspirant to the throne, but Diwan Giddu Mal, an administrator under Noor Muhammad Kalhora, gave his backing to Murad Yab. ${ }^{225}$ On Diwan Giddu Mal's insistance, Ahmad Shah Abdali gave authority to Murad Yab to rule, with the condition that a yearly payment of Kharaj of Rupees 14 lakhs was made to Kabul. ${ }^{226}$ Murad Yab Khan was also given the title of Sar Buland Khan by Abdali. ${ }^{227}$ Murab Yab's ascent to the throne was however not supported by his step-brother Ahmed Yar Khan, who later allied with Attar Khan Kalhora. ${ }^{228}$ Thus started a phase of intra-Kalhora rivalry and, as a consequence, political instability in Sindh.

During this phase of Kalhora history, also known as the 'later Kalhora phase', Afghan intervention was invited by various Kalhora contenders for the throne of Sindh, seeking political sanction for their claims to rule. This led to a strengthening of the Afghan hold over Sindh; it entailed frequent tribute missions from Sindh to Afghanistan and, as a consequence, a drain on the Sindh economy. The political

\footnotetext{
$224 \quad$ Lari, A History of Sindh, 146-148.

225 Yusuf, 'The Dutch Trade in Sind in Historical Perspective,' 37.

226 Foreign Department, Secret Consultations, no. 22, 26 February 1776. National Archives of India [hereafter NAI].

227 Qani, Tuhfatul Kiram, V.3, 112.

228 David Seaton, Tarikh-i-Kalhora, pp. 12-15; Mirza Kalich Beg Fredunbeg, A History of Sind, V.2, $2^{\text {nd }}$ ed. (Karachi : Scinde Classics, ,1982), 155.
} 
chaos caused by the civil conflict occurred at the same time as regular changes in the course of the Indus river. The later Kalhora rulers, therefore, had to frequently change their capital, and this also contributed to economic instability. Until 1754, the Kalhora capital was Khudabad; because of a change in the course of the western branch of the Indus, Murad Yab Khan relocated the capital to Muradabad in 1756. The following year he again moved the capital, this time to Ahmedabad, near Sakrand. In 1758 Murad Yab built another city near Hala; he named it Khudabad and made it his capital. ${ }^{229}$

Murad Yab Khan was not a competent ruler. He had little knowledge of statecraft and, having spent fourteen years away from Sindh, was out of touch with local affairs. Nevertheless he did put effort into increasing Sindh's revenues by making several requests to the Dutch VOC through its agents in Masqat, to establish a trading base in Sindh. ${ }^{230}$

Since the mid-seventeenth century, the VOC had been establishing commercial factories in India, and by the mid-eighteenth century it was well established in places such as Qasimbazar, Baranagore, Patna, Pulicat, Surat, Chinsura, Balasore Negapatnam and Cochin. But throughout the 1600s, neither the English nor Dutch could establish trade bases in Sindh due to the unstable political conditions there and sea piracy. Only in 1739, under the Kalhoras, did the prospects for trade in Sindh became conducive to the Europeans. On 10 July 1757, with Murad Yab's encouragement, the VOC ships de Pasgeld and de Marienbosch set out from Batavia (Jakarta) on an exploratory voyage to Sindh, in order to assess trading prospects there. The ships carried a quantity of goods for sale: Javan sugar, mace, spices such as cloves and cinnamon, and metals such as lead, zinc and iron; they also carried tin from Muscat, where a stopover was made on 15 September 1757. The sale of Javan sugar, of which the VOC had an abundant supply, was the Dutch and Diewel-Sind (Pakistan), in the 17th and 18th Centuries: Based on Original Dutch Records, (Karachi: Institute of Central \& West Asian Studies, 1993), 25.

230 Mazhar Yusuf, 'The Dutch Trade in Sind in Historical Perspective', in Floor ed. The Dutch East India Company (VOC), 37. 
Company's main motive for sending an exploratory mission to Sindh. The cargo was under the charge of Captain Wolphert Abraham Brahe and Nicholas Mahue. ${ }^{231}$ From Muscat the ships set sail for Karachi (Sindh) on 15 October $1757 .^{232}$ The Dutch were unfamiliar with navigation routes from Muscat to Sindh, and so hired a pilot from Muscat; it was not difficult to find one because there were strong trading relations between Muscat and Sindh. ${ }^{233}$ They also hired a broker, Anand Ram, who was from the Hindu-Baniya caste, and a few English sailors. ${ }^{234}$ The Baniyas had also acted as brokers (gumastas) for the English traders during the Mughal period, when the East India Company had opened a factory in Sindh more than a century earlier (the factory operated from 1635 to 1662). The names of the famous gumastas are included in Company records: Naval Das and Bumba Mal, for example. ${ }^{235}$

The Dutch records tell us that Karachi was mainly inhabited by traders and seamen. The local traders were mainly from the Baniya caste and the rest of the Sindhis who transported merchandise to Cambay, Camare near Goa, Cunkanse near Gujarat, and Malabar and to central Asian ports such as Muscat and places along the Persian coast. Sea piracy was a major problem faced by Sindhi seamen, and even by the Dutch and the English, along the Arabian Sea trade routes. ${ }^{236}$

The VOC merchants Brahe and Mahue conducted their trade in Karachi through their broker, Anand Ram, a man who spoke the local language and escorted local merchants to the Dutch ship to see the merchandise available for sale. Brahe and Mahue soon realised that their broker was probably passing on to Sindhi merchants information about how the Dutch traded in Muscat and the prices that local traders paid for Dutch goods. This suspicion about Anand Ram was raised when, to the surprise of the Dutchmen, the Karachi merchants wanted to buy Dutch

Floor ed., The Dutch East India Company (VOC), 50-51. M.H Panhwar, 'Introduction', in Floor ed. The Dutch East India Company, 12. Floor ed., The Dutch East India Company (VOC), 52. 'VOC 2937, Report on Trade in Diewal Sind, 1757' in Floor ed. The Dutch East India Company (VOC)), 57. University Press, 1966), 104.

VOC 2937, Report on Trade in Diewal Sind, 1757' in Floor ed. The Dutch East India Company (VOC), 58.
} 
goods on the same terms that had applied in Muscat; specifically, they demanded credit terms of two to three months, and were unwilling to pay more for goods than merchants in Muscat had paid. Brahe and Muhue, handicapped by their inability to speak the local language, accepted that they could not change their broker. Also Anand Ram was the only person who could speak Portuguese (Brahe and Mahue could also speak Portuguese) and could converse with them. ${ }^{237}$ This is an example of how Dutch trade was impeded by the Dutchmen's reliance on local brokers.

The merchants in Sindh asked the Dutch to leave their ships and conduct their trade onshore in Karachi. On the locals' advice, Brahe and Mahue met the Shahbandar (comptroller) of the port city, a man named Khwaja Nouria and probably a Persian; he played a vital role in the maritime trade. In Muscat, the comptroller of ports was not cooperative in his dealings with the Dutch traders. Although the Muscat government allowed the Dutch some privileges, the foreign merchants could sell only a portion of their cargo of spices, and a large quantity of the sugar they had on board remained unsold. In contrast, the comptroller of Sindh gave them much more assistance. The Dutch met many Sindh merchants in the Sindhi comptroller's caravanserai. The comptroller of Diewal Sindh or Auranga Bunder's waqil even encouraged the Dutch to settle there. ${ }^{238}$ This VOC expedition therefore made more profits in Sindh than in Muscat.

The governor of Diewal Sindh, when asked by the Brahe and Mahue for assistance, replied that he "was very pleased that the Dutch had come to trade there. ${ }^{239}$ Brahe and Mahue reported that, apart from sugar, they could not sell any other product in Karachi. On 18 November 1757, the Dutch merchants sailed from Karachi to Diewal Sindh. Their agent, Anand Ram, played a constructive role here. From Diewal Sindh he went to Auranga Bunder and Dera. The Dutch record is very useful in telling us that there were a few pockets in Sindh, such as Dera, that were controlled by tribal chiefs who had tributary relations with Sindh's Kalhora rulers. In

\footnotetext{
$237 \quad$ Ibid., 58.

238 Mazhar Yusuf, 'The Dutch Trade in Sind in Historical Perspective', in Floor ed. The Dutch 239 East India Company (VOC), 40. Ibid., 63.
} 
Auranga Bunder and Dera the broker Anand Ram looked for local people who could act as middlemen and help Brahe and Mahue sell their merchandise. ${ }^{240}$ Anand Ram found another Baniya, a man called Nebhomal, who could act as a broker for the Dutchmen in Diewel Sindh. In Auranga Bunder, Nebhomal and Anand Ram arranged accommodation and a warehouse for the foreign merchants. In Diewel Sindh, Brahe and Mahue met Kattani, who was the comptroller's agent; he gave them encouragement by offering a place in which to establish their factory. ${ }^{241}$

This Dutch exploratory mission was to be very decisive for the development of Dutch trade in Sindh - that is, for the VOC's chances of establishing a trading post there. However the English quickly followed the Dutch into Sindh and were soon offering stiff competition. Even though it was not until 1758 that the English Company again established a factory in Sindh, the governor of Bombay Richard Bourchier, had, in January 1757, sent to Aurangabad his private ship carrying merchandise such as sugar, iron, raw Bengal silk, pepper, sappanwood, cardamom, ivory, tin, zinc and lead. This English expedition posed stiff competition to the Dutch in Sindh by offering prices that were three to five per cent lower than the prices that the Dutch charged. To add insult to injury, the Dutch believed that the English had bought their merchandise from a Dutch factory. To outmanoeuvre the Dutch, the English also offered the Sindhi merchants long-term credit, as much as one year or as long as they wanted. Sindhi merchants were even allowed to repay in kind the money they had borrowed from the British creditors. The Dutch suspected that the English would go as far as selling their goods at a loss in order to oust them from Sindh. Bourchier, to win over Murad Yab Khan, sent him yearly presents, and sent one to coincide with the arrival of the English ship in Auranga Bunder. Yar Muahhad's envoys demanded a gift for the Sindh king from the Dutch as well. The Dutch response was to say they had no knowledge of such a custom, that their expedition was experimental, and they had not yet decided to establish a factory in Sindh. Dutch gifts were nonetheless soon sent to Murad Yab. To Brahe and Mahue's 
surprise, they were returned with just words of appreciations and a promise of cooperation. $^{242}$

Sindh's economy began to decline after the Kalhora state came under Afghan suzerainty; the drain of wealth to Qandahar was partly responsible for this. Dutch records show us that around the latter half of the eighteenth century the circulation of cash in Sindh was diminishing because of economic decline. Dutch traders were instructed by the VOC's Supreme Council to start accepting payment in products such as chankos (shells), cattoen (linen cloth or flax) and other textiles, and poetiock (a kind of Himalayan fragrant root). ${ }^{243}$ The Dutch record tells us that many Sindhi traders were troubled by the unrest caused by the rival groups in Sindh wanting to overthrow Murad Yab Khan Kalhora as ruler. Many of them also complained to the Dutch trading team about the oppression suffered by many people in Sindh under the reign of Murad Yab Khan. ${ }^{244}$

It is fair to suggest that the economic instability caused by political turmoil during Murad Yab's reign was at the heart of Sindhi merchant grievances. As for the Dutch expedition, it floundered because of aggressive competition from English merchants. The Sindhi merchants were more interested in buying goods from the English than the Dutch. The Dutch believed that they could compete more effectively with the English if they could have allowed their agent to stay there for one year, especially during the time when the price of goods was high. But the VOC was not willing to appoint an agent to Sindh for a year. The Dutch expedition led by Brahe and Mauhe left Diewal Sindh on 20 April 1757. Brahe was reprimanded by the VOC for the failure of the expedition and was forced to pay for its financial losses. ${ }^{245}$

The Dutch stronghold in the Persian Gulf also declined in the latter half of the 18th century. By 1759, the VOC station at Bander Abbas was no longer

\footnotetext{
$242 \quad$ Ibid., 67-68.

243 Floor ed. The Dutch East India Company (VOC), 51.

244 Mazhar Yusuf, 'The Dutch Trade in Sind in Historical Perspective' in Willem Floor ed. The Dutch East India Company (VOC), 40.

245 Floor ed., The Dutch East India Company (VOC), 52-56.
} 
operating, and the station at Kharg was abandoned in 1765. With this started an era of British supremacy in the Gulf region that lasted for almost 200 years, making it very difficult for Dutch traders to operate profitably in Sindh. ${ }^{246}$ The English gained from the Dutch trade debacle in this region. As noted above, the Dutch packed up and left in April 1757, and the British opened a factory in Sindh in 1758.

We have seen that frequent transfers of the state capital, caused by changes in the course of the Indus river, further weakened the Sindh economy. Murad Yab also had politically disruptive forces to contend with. During his rule he had to deal with defiant local chiefs such as the Jam Hajajee, chief of Hijaje district and the Shahbunder of Kikrala. ${ }^{247}$ Another problem was that Murad Yab Khan had discontinued the system of tariqat (sufic path) followed by his Kalhora predecessors. These factors combined to make his rule unpopular, and in 1757 the faqirs (followers of the Kalhoras) and the Kalhora chiefs themselves, as well as the Jats and the Baluchs decided to replace Murab Yab with his brother Ghulam Shah. ${ }^{248}$

Murad Yab was married to a daughter of the Imam of Mascat, ${ }^{249}$ and because he himself was troubled by Sindh's many problems, as well as the demands for Kharaj by Ahmad Shah Abdali, he decided to leave Sindh and migrate to Mascat. He prepared for his departure by sending a large quantity of cash and valuable to Muscat in advance. But before he could leave for Muscat, a group of sarais (followers of Kalhoras) stopped him by encircling his fort and imprisoning him on 29 August 1757. ${ }^{250}$ Attar Khan, the third son of Noor Muhammad, was, at the time, still at the Persian court as hostage. Before Ghulam Shah could obtain sanction for his enthronement from the Afghan king, Attar Khan obtained a parwana (order) from Abdali that authorised him to be Sindh's ruler.

Syed Farooq Hasnat, 'An Historical Survey of the European Interests and Control in the Persian Gulf Region' in Journal of Research Society of Pakistan, vol. xviii, no.2, 1981, 36. Lakho, Kalhora Daure Hukumat, 144. David Seaton, Tarikh-i-Kilhora, 21-31. Ibid. David Seaton, Tarikh-i-Kilhora, pp. 21-31, Fredenbeg, A History of Sindh, 155. 
Many of Ghulam Shah's, supporters, people who had backed his claim to the Sindh throne, now withdrew their support in favour of Attar Khan. Ghulam Shah then fled to Jodhpur. Attar Khan reached Sindh in November 1757 accompanied by some Afghan soldiers; he was also supported by his brother Ahmed Yar Khan. He assumed the rule of Sindh and to, meet the Afghan demand for tribute, started squeezing tax payments from his subjects. ${ }^{251}$ His officials were ill-disciplined, and they further oppressed the peasants by extracting yet more taxes from them. ${ }^{252}$ One year after Attar Khan's ascent to the throne, Ghulam Shah mobilised an army and attacked Attar Khan's court. In May 1758 this culminated in a war in Roree between forces commanded by Attar Khan and Ghulam Shah. Ghulam Shah's army won this battle. Thus Attar Khan's first term as ruler of Sindh had lasted for six months. ${ }^{253}$

Attar Khan, accompanied by his brother Ahmad Yar Khan, rushed to Abdali's court to request that he be reinstated as ruler of $\operatorname{Sindh},{ }^{254}$ a request supported by Diwwan Giddu Mal. Ahmad Shah Abdali affirmed Attar Khan as ruler of Sindh and, to displace Ghulam Shah, sent an army under an Afghan commander, Haji Utay Khan. ${ }^{255}$ In return for allowing Attar Khan to rule Sindh, Abdali required Ahmad Yar Khan to remain in Qandahar as a yarghmal. ${ }^{256}$ This was a time of chaos in Sindh. Afghan amaldars( revenue collecters) plundered at will wherever they went and, taking advantage of the situation, the local Jhokia tribe attacked and plundered in Sindh. ${ }^{257}$ Ghulam Shah again had to flee and sought shelter from Jam (chief) Hajjajee in Sindh's district of Hajjaje; here he obtained the permission from the Jam to build a fort in which to reside. ${ }^{258}$

The second term of Attar Khan's rule began in December 1758, but the political situation in Sindh did not settle down. Ghulam Shah had not giving up

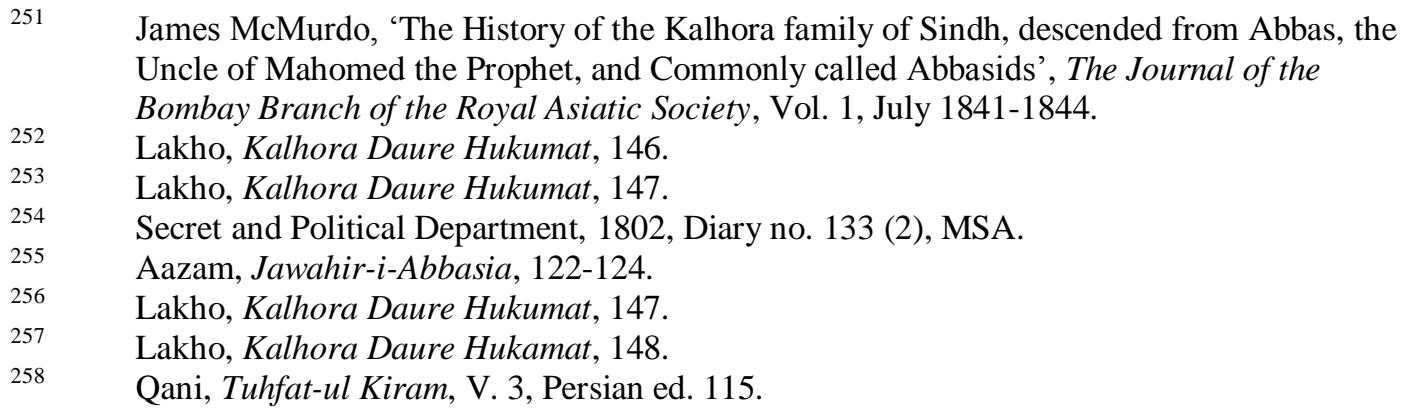


hope of reclaiming the throne, and again prepared for war with Attar Khan. But now Sindh's Kalhora chiefs decided the best solution was to divide the state among the three conflicting Kalhora factions - that is, the factions led by Attar Khan, Ghulam Shah and Ahmed Yar Khan. In the December 1758 Treaty of Chachkan, the region from Shah Garh to Nasarpur, and region bordering Thatta, was given to Ghulam Shah, and the rest of Sindh's territory including Thatta was divided between Attar Khan and Ahmed Yar Khan. ${ }^{259}$ However, after dividing Sindh into three administrations, the population was disturbed again by the plundering raids of the Afghans, so the Ulema (learned men, plural of Alim) of Thatta requested Ghulam Shah to issue a farman announcing the implementation of Sharia (Islamic law). Ahmad Yar Khan, who was at the Afghan court at this time, requested Abdali to grant a parwana that established him as Sindh's ruler. Abdali, too, now judged Attar Khan to be incompetent and believed that Ahmad Khan could bring peace to Sindh, so he endorsed Ahmad Khan as Sindh's ruler. At this point, however, Ghulam Shah, decided that it was best that he rule the whole of Sindh on his own. Attar Khan, therefore, had to flee and take refuge in the western part of Bahawalpur, the stronghold of chiefs Bahadur Khan Allani and Akhtiyar Khan Mandani. Bahadur Khan helped Attar to fight Ghulam Shah and a battle between the two Kalhora factions took place in Ubawara. ${ }^{260}$ Ahmad Yar Khan who had Ahmad Shah Abdali's sanction to rule Sindh, knew that Ghulam Shah had gone to war with Attar Khan, and so decided not to go to Sindh and assert his claim to the throne ${ }^{261}$ Ghulam Shah resumed his position as ruler of Sindh after defeating Attar Khan Kalhora on 28 May 1759. He then appointed Muhammad Qaiyam Kokaltash as the Nazim of Thatta. ${ }^{262}$

After reclaiming the Sindh throne, Ghulam Shah was required to acknowledge the sovereignty of Ahmad Shah Abdali and agree to pay a yearly kharaj. He also established the Hyderabad fort. Attar Khan Kalhora, who later submitted to his brother, was well received at court and was granted many jagirs. ${ }^{263}$

\author{
Lakho, Kalhora Daure Hukumat, 149. \\ Qani, Tuhfat- ul-Kiram. V.3, Persian ed., 115. \\ Lakho, Kalhora Daure Hukumat, 150. \\ Qani. Thufat- ul-Kiram, V.3, Persian ed., 114-115. \\ Secret and Political Department, 1802, Diary No. 133 (2), MSA.
}


But Ghulam Shah's reign was again troubled by rebelliousness and civil unrest. The Pathans in Sindh rebelled; the rulers of Kelat and Cutch led rebellions against the Kalhora government, and so did the Samma chief of Kakrala in lower Sindh. ${ }^{264}$ Khosas tribesmen plundered Khudabad, and Ghulam Shah was forced to deal with them in May 1759, after which he established military check posts in the villages in that area. ${ }^{265}$ To strengthen his control in Sindh, Ghulam Shah also needed to recapture territories in the region from Thatta to the Arabian Sea coast. He also annexed Siwistan. Ahmed Shah Abdali allowed the Sindh ruler to strengthen his hold on Sindh's tribal areas as long as he was regular in paying him the annual tribute.

As noted above, Murad Yab Khan was forced to move his capital several times; the move to Khudabad was his last. But Khudabad did not last long as Sindh's capital; in 1760 the then ruler Ghulam Shah had to move to Shahpur, near Nasarpur. ${ }^{266}$ The unstable nature of the Indus river's course led to the abandonment of several ports as well. The port of Auranga Bunder built by Aurangzeb when he was the governor of Multan and Sindh was, during Ghulam Shah's reign, abandoned due to the river's course change, so Ghulam Shah had to build a new port that was named Shah Bunder. This too did not last long and was replaced by the Ketki Bunder port. ${ }^{267}$ Captain James McMurdo, writing in the 1840s, suggested that the conditions for local traders in Sindh had never been favourable. He noted that the constant change of rulers was accompanied by shifts in the political capital. Political chaos in Sindh emboldened the various tribal chiefs, and the rebel movements they led made the transportation of goods through their territories very difficult. ${ }^{268}$

In September 1761, Sindh's agent in the Afghan court, Diwan Giddu Mal, asked Ahmad Shah Abdali to bestow on him the title of 'Shah Wardi Khan'; the Afghan king agreed to do this. And then, in 1765, Ahmad Shah Abdali handed over 
the region of Derajat to Ghulam Shah. ${ }^{269}$ Sindh was thus closely tied to Afghanistan at this time, and good trading relations were facilitated by the development of strong trading networks along the Qandahar to Thatta route.

At the time when the Kalhora brothers Ghulam Shah and Attar Khan were fighting each other for supremacy, the English East India Company decided to open a factory in Sindh. Sindh had its troubles, but so did all of north-west India. Particularly troublesome was the conflict between the Afghans, Sikhs and Marathas in the Punjab. The English East India Company opened its factory in Thatta with an outpost in Shah Bundar in 1758. The purpose of the Company's move into Sindh was to secure a monopoly of the saltpetre trade and to sell woollen cloth to merchants from Qandahar and Persia (there was at this time an open trade between Sindh and Persia through Qandahar). It also wanted to profit from selling Sindhi cattle to Bombay. ${ }^{270}$ George Bourchier, the English officer sent to Sindh for the purpose of establishing the EIC factory there, received on 18 December 1758 an instruction from Bombay Castle to acquire saltpetre in Sindh at a favourable price and obtain permission for refining it in Sindh before shipping it to England. He was also instructed to inquire about the quality and price of Sindhi cloth including chints $?^{271}$

The English factory in Sindh, however, was one of the Company's less important trading bases; the volume of its trade in woollens was small and it was not embedded in Sindh's political system in the way that EIC factories in Fort William, Surat, Broach and Cambay were. Ghulam Shah recognised that English trade in Thatta would be advantageous to his government and that it was worthwhile, therefore, to be accommodating in dealings with the British merchants. In order to encourage British trade, he granted several exemptions and privileges to the English factory. On 22 September 1758 he issued orders to the deradars (people in charge of deras or districts) and mutassadis (custom officers) to collect from the English Journal of Pakistan Historical Society, V. LVII, no. 2., April-June 2009, 17-18.

270 Sorely, Shah Abdul Latif of Bhit, 30.

271 Ibid., 30. 
Company a custom duty of only 1.5 percent of the market price of goods they purchased for shipping to Bombay. ${ }^{272}$ Duties imposed on the European goods brought from Bombay to sell in Sindh were also generous; the costs for the Company of custom duties, passports and accommodation were half of those that the Multani and other merchants in Sindh were required to pay. The EIC factory in Sindh was granted a patta (permit) to export or import any goods into and out of Sindh. The English merchants were allowed to sell their goods at any price they themselves chose. The ruler ordered the farmers and officers of the Sircar (provincial units) not to cause any hindrance to the English traders or charge for the movement of EIC goods from one part of Sindh to another. Ghulam Shah also allowed the foreign merchants to construct their warehouse in Auranga Bunder or Thatta and ordered his officers to assist them with this. ${ }^{273}$

Ghulam Shah declared in another parwanah, dated 22 April 1761, that apart from the English factory, no other Europeans would be allowed to enter the ports of Sindh and engage in trade there. ${ }^{274}$ The English Company was, as requested, given monopoly of the saltpetre trade. In the eighteenth century saltpetre was used for making glass and dyes for the cloth industry and also for manufacturing gunpowder. British monopoly of the saltpetre trade in India fed the burgeoning cotton industry in Britain and also the big expansion of the glass and pottery manufacturing industries. ${ }^{275}$ The EIC Resident based in Bombay, Robert Erskine, also requested Ghulam Shah to exempt the Company from paying transit duties on the Indus river which was Rs 25; this demand was also granted. ${ }^{276}$

We can deduce Ghulam Shah's reasons for making concessions to the EIC; he wanted to reinvigorate the Sindh economy. The river Indus had changed its course during his reign, forcing the abandonment of a large tract of arable land and,

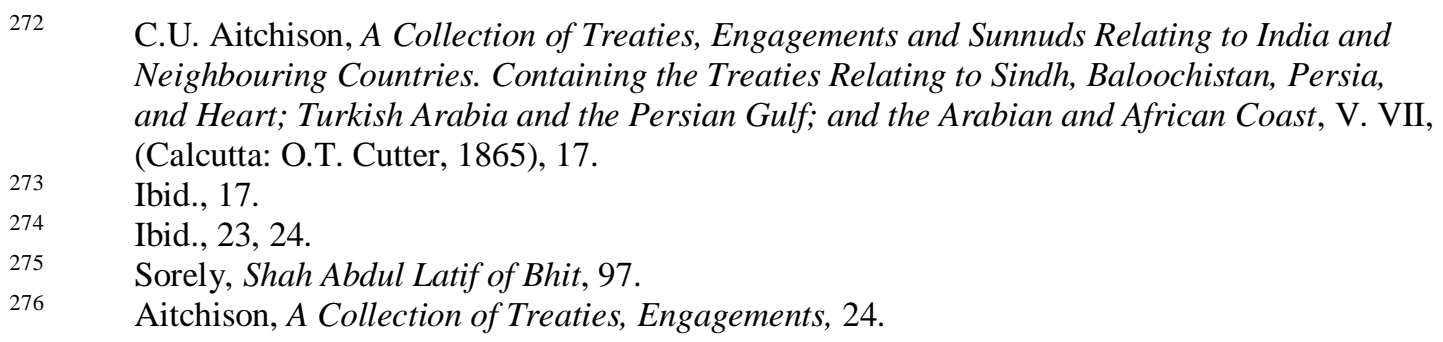

C.U. Aitchison, A Collection of Treaties, Engagements and Sunnuds Relating to India and Neighbouring Countries. Containing the Treaties Relating to Sindh, Baloochistan, Persia, and Heart; Turkish Arabia and the Persian Gulf; and the Arabian and African Coast, V. VII, (Calcutta: O.T. Cutter, 1865), 17. 
therefore, reducing the state's revenue. Sindh's military capacities had also declined under Ghulam Shah. He depended chiefly on the retainers of his jagirdars and heads of military units commanded by Kalhora chiefs, both were irregularly maintained. He purchased two cannons from the English. He also asked the English to send cannon operators to Sindh, but this request was turned down by the EIC; .a military strengthening of the Sindh state was not in the Company's interest. In his struggles with political rivals and uncooperative tribes, Ghulam Shah sought support from the English Company, but in this also he was not successful. He had asked the Company to help him against the Cutch by supplying an armed vessel; the Company refused because it had good trading relations with Cutch and had received requests from its masters not to interfere in local politics. The Company also needed all its vessels in Bombay to protect that port from the French cruisers which had now reached the Malabar coast. ${ }^{277}$ Preetam Das, an agent of the English in Sindh, informed Erskine who had been sent to Sindh by the EIC, that Ghulam Shah was disillusioned with the English because he could not get from them the benefits that he had expected earlier. ${ }^{278}$ Also, because Ghulam Shah was unable to pay the tribute that Sindh owed to the Afghans, he decided in 1762 to attack Cutch; it was a strategy designed to replenish the state's finances. ${ }^{279}$ Ghulam Shah's forces raided Cutch and seized the small fort of Sindree. ${ }^{280}$

EIC trade in Sindh took the form of Company purchases of saltpetre in Sindh and Company sales of woollen and Persian cloth to Sind's Multani merchants, However the trade in woollens was not strong. Also, the company had to advance credit to the Multani merchants to enable them to purchase the woollen clothing The EIC Sindh factory records show that the Company advanced a loan of Rs. 200 to Gulabroy, the ijaradar (revenue farmer) of Thatta, who was also the Nawab of Cambay's trade agent. Persian and Pathan merchants were also interested in purchasing English woollens, ${ }^{281}$ but they were not allowed to enter Shah Bundar,

\footnotetext{
277 Sindh factory Records, 1762-1765, MSA.

278 Sindh Factory Records, 1762-1765, MSA.

$279 \quad$ Lari, A History of Sindh, 149.

280 Sindh Factory Records, 1762-1765, MSA.

281 Ibid.
} 
where the company factory had its outpost. So the English merchants had to transport their goods to Thatta to sell them to these merchants, and this involved heavy transportation costs. ${ }^{282}$

The English company faced other problems. The Kalhoras, like the Mughals, had allowed the officials at the local level to retain their prevous positions once they were sure of regular payments from them. As a consequence, local chiefs continued with their practice of exploiting and harassing their subordinates with illegal exactions. The Shahbander and the custom officers of Thatta frustrated the English with delays in clearing their goods. EIC Resident Robert Erskine, was told by a local merchant, Preetamdas, that the Prince (Ghulam Shah) had instructed the custom officer to harass the Company with such delays, and this was because he was disappointed with the Company's unwillingness to help him against Cutch by providing warships.

If the Persian and Pathan merchants had been allowed to enter Shah Bundar, the Company could have collected from them custom duties to the value of 2.5 percent of the price of the goods sold. And so the Company requested Ghulam Shah to allow these merchants to enter Shah Bundar. Ghulam Shah turned down the request because Sindh was under Afghan suzerainty, and if the Pathan merchants got to know about the river routes and the Kalhora regime's forts inside Sindh's borders, then the security of Sindh would be threatened. Ghulam Shah paid part of the Kharaj that Sindh owed to Afghanistan in woollens that had been purchased from the English at low cost. Afghani merchant were also purchasing woollens directly from the English, and this went againt Ghulam Shah's interests. He therefore wanted to cut out the Afghan traders in order that he himself could supply woollens to Ahmed Shah Abdali. ${ }^{283}$

The Sikhs made frequent attacks on places in Sindh, and these attacks disrupted the British woollens trade, however, the Afghans decisively checked Sikh expansion, recovered provinces lost to the Sikhs, and removed blockades along 
routes to Qandahar and Kabul. ${ }^{284}$ The Afghan King ceded the regions around Sikarpur and Multan to the Kalhoras in $1823 .^{285}$

There had been a vibrant internal trade between Thatta and Sikarpur in the middle of the eighteenth century, centered in Karachi. The merchants from Sikarpur came to Thatta annually, bringing with them fabric and spices such as asafoetida, and also cash to buy various imported goods; these goods were then sent to other parts of Sindh. This trade had declined by 1765 because of Ghulam Shah's oppressive policies and the imposition of taxes on the traffic of goods by district officials who were in conflict with the Sindh king. Sikarpuri merchants maintained some trade connections with Karachi in the latter half of the eighteenth century when it was under the Afghan rule, ${ }^{286}$

When the English opened a factory in Thatta in 1758, there were thirty established and reputable Multani merchants' houses and some Surat merchants in the city. By 1776, many of these merchant establishments had closed down: none of the Surat merchants remained and, of the thirty Multani merchants, only one still operated. The import of raw silk in Sindh decreased from two to three hundred bales in 1758 to an average of forty bales in 1776 . As noted above, the trade between Sikarpur and Thatta was in decline by $1775 .^{287}$

Economic decline in Sindh under the later Kalhoras is also evident in the fall in the value of the local currency. The currency in Sindh was 'current rupees'; in 1758120 current rupees were worth 100 silver rupees. The value of current rupees declined in 1776 , when 140 current rupees was equivalent to 100 silver rupees. Due to the shortage of silver in Sindh at the time, it is estimated that the value of 100 rupees in the silver currency might have been as high as 150 current rupees, if the demand for rupees in Thatta went up to twenty thousand rupees. ${ }^{288}$

\footnotetext{
$284 \quad$ Sindh Factory Records, 1762-64, MSA.

285 Ikram Ali Malik, 'Ranjit Singh's Relations with the Amirs of Sindh: 1802-1839,' in Sind Through the Centuries, ed. Hamida Khuhro (Karachi: OUP, 1966), 161.

286 Foreign Department, Secret Consultations, 26 February 1776, no. 22, NAI.

287 Ibid.

288 Ibid.
} 
The Company faced another problem. In 1764, because the supply of saltpetre from Bengal was disrupted, the Company needed to acquire as much of it as as possible from Sindh. The Imam of Muscat, however, wanted to buy saltpetre from Sindh and Ghulam Shah, who was now disinclined to cooperate with the Company, considered giving his consent to the Imam; the sale of saltpetre to Muscat would be a means of retrieving the treasure that his brother Murad Yab had sent to Muscat back in 1757. ${ }^{289}$ In the end, however, Ghulam Shah turned down the Imam of Muscat's request because he essentially wanted EIC trade in Sindh and, therefore, needed to allow the Company to maintain its monopoly of the saltpetre trade. Nevertheless he requested that the Company supply 500 maunds $(16,875 \mathrm{~kg}$ ) of saltpetre to the Imam, and the Company did this. ${ }^{290}$ Once the Seven Years' War between Britain and France had ended in 1763, the British interest in the Persian Gulf region became less commercial and more political, because the Gulf was linked to the security of its strongholds in India. ${ }^{291}$

As we have seen, Thatta declined as a centre of trade during the course of the eighteenth century, and Karachi came to replace it as Sindh's most commercially important seaport. Sindhi Bania were prosperous in the eighteenth century, and one of them, Seth Bhojmal from Karraka Bunder in Sindh, had agents in Muscat, Shiraz, Baharain and Bushire. Due to his initiative, Karachi had been established as a new seaport in the 1720s because a change in the Indus river's course had resulted in Kharraka Bunder's decline as a port city. ${ }^{292}$ After 1785 the Bhattia merchants also dominated the trade in Muscat. ${ }^{293}$ By the mid-eighteenth century Thatta was mainly a centre of handicraft production, not a trade port, and its links with the international market were severed.

\footnotetext{
289 ibid.

290 ibid.

291 Syed Farooq Hasnat, 'An Historical Survey of the European Interests and Control in the Persian Gulf Region,' in Journal of Research Society of Pakistan, vol. xviii, no.2, 1981, 3352. Bukhara to Panama, (Cambridge: Cambridge University Press, 2000), 6. Ibid., 38
} 
It was at this time, however, that Shikarpur emerged as a commercial and financial hub of the Durrani Afghan Empire under Ahmad Shah Abdali. Shikarpur became important as a consequence of the decline of the Multani trading network, a result of the Russian policy of excluding the Indian traders from participation in Russia's internal trade and the halting of Russian trade with Persia. Shikarpuri merchants had trading links with many places in Persia and Central Asia. ${ }^{294}$ Merchants who belonged to the Sindh trading diasporas had interests in common with the British, and they did not support the unstable rule of the Kalhoras in Sindh. Hyderabad established by Ghulam Shah in $1768^{295}$ also arose as a new urban centre in the late $1700 \mathrm{~s}^{296}$

Ghulam Shah always wanted to throw off the yoke of Afghan hegemony. He even planned an attack on Qandahar. ${ }^{297}$ He reduced the Kharaj payment to Afghanistan to eleven lakhs and then to 7 lakhs of Rupees. By November 1763, when Ahmed Shah's influence in Afghanistan had declined and he faced revolts by the governors of Herat and Balochistan, Ghulam Shah too tried to assert his independence and withheld the payment of tribute to Afghanistan. However the Afghanistan agent at his court continued to press him to pay the annual tribute. After the death of Ghulam Shah in 1772, the Umra placed Sarfaraz Khan on the Kalhora throne. This was an independent action, done without the prior consent of the Afghan court. Ahmad Shah Abdali also died in 1772, and his son, Prince Taimur, was in Khurasan at the time. Taking advantage of that, the wazir-i-Azam (Prime Minister) of Aghanistan, Shah Wali Khan, raised his own son-in-law, Sulaiman, to the throne. Taimur travelled to Qandahar, declared Sulaiman's enthronement to be invalid, and imprisoned him. He then gave his sanction to the enthronement of Sarfaraz Khan as the new ruler of Sindh. Sarfaraz Khan was also given the title of Khuda Yar Khan and the region of Dera Gazi Khan was also given to him to rule. ${ }^{298}$

\footnotetext{
$294 \quad$ Ibid., 38.

295 S.P. Chablani, Economic Conditions in Sindh, 1592-1843 (Calcutta: Orient Longmans Ltd., 1951), 63.

296 Markovits, The Global World of Indian Merchants, 37-38.

297 Lakho, Kalhora Daure Hukumat, 161.

298 Lakho, Kalhora Daure Hukumat, 162.
} 
Sarfaraz Khan's reign is infamous as a period of maladministration that led to the fall of the Kalhora dynasty. His policies were also responsible for the closure in 1775 of the EIC factory in Thatta. Sarfaraz Khan's policy towards the Company's traders in Sindh was determined by the nature of the trade they conducted there that is trading with the Afghan traders. Trade in woollens constituted the main part of EIC trade in Sindh, and the Sindh government paid a part of the tribute it owed to Afghanistan in woollens bought from the Company. In order to avoid paying custom duties in Sindh, Afghan wool traders wanted to trade directly with the Company by means of the Karachi, Mekran and Kelat route rather than the Indus route; the consequence was, in Sorely's words, a 'continual triangular conflict of interest' when it came to trade in woollens between Sindh, Afghanistan and the Company. ${ }^{299}$ The Company sold its woollens to the king of Afghanistan through agents, or chuppers, sent from Afghanistan. However the Company also wanted to trade directly with the Afghan traders, and this was because of the new Kalhora ruler's foreign trade policy; instead of conforming to the favourable terms-of-trade policies offered by Ghulam Shah to the Company, custom officers under Sarfaraz Khan levied heavy transit dues on the traffic of goods in and out of Sindh, and Sarfaraz supported his officers in this practice. He demanded that the English pay customs duties to the value of fifty per cent of the price of the woollens they sold. When the Company refused to pay this, he prohibited the Company's woollens trade in Sindh, rendering it impossible for the English to maintain their factory there. ${ }^{300}$

Sarfaraz Khan also alienated the Talpurs and other Baluchis by killing their leader, Meer Bahram. This estranged his relations with the Baluchis on whom the Kalhoras had always depended militarily, and this breach of trust ultimately led to the overthrow of the Kalhora dynasty. ${ }^{301}$ The civil war in Sindh in 1775 led to the removal of Sarfaraz Khan as Sindh's ruler. The Talpurs (Baluchis), with whom the Kalhoras had allied, on whom they had often depended, and who were included in 
the ranks of their followers and mercenaries, ultimately overthrew the Kalhora regime after a brief period of civil war between the two dynasties.

\section{Conclusion}

The collapse of the Mughal rule facilitated the rise of the Kalhoras in Sindh in the early eighteenth century. But the process of independent state formation by the Kalhoras was checked when Sindh was subjugated by Persia in 1739; for a short time after this Sindh was ruled by both Nadir Shah and the Kalhoras, who presided over parallel administrations. In the late 1740s Sindh was incorporated into the Afghan empire and the Kalhora rulers now became politically subject to the Afghanistan. While all of the other successor states in India derived their legitimacy from the Mughals, the rulers of Sindh sought a mandate for the right to rule from the Afghan king.

Ghulam Shah Kalhora was head of the Sindh state for 15 years, from 1757 to 1772. He tried to rule Sindh independently, but did not ever succeed in throwing off Afghan hegemony. His successor, Sarfaraz Khan, resumed the practice of seeking sanction from the Afghan king for the right to rule Sindh, thereby strengthening the Afghan hold over Sindh in the 1770s. The Kalhora state became progressively weaker under Sarfaraz Khan, paving the way for Talpur rule in Sindh..

This chapter has shown how the Kalhora state builders attempted but failed to break free from Persian and then Afghan hegemony. Not only did the Kalhoras fail to achieve independence. Afghan suzerainty over Sindh was actually strengthened when, during the phase of intra-tribal struggles for supremacy among the later Kalhoras, each aspirant sought sanction for their claim to the Sindh throne from the Afghan ruler. Tribal warfare among the ruling Kalhora tribe was also responsible for internal political instability and, eventually, the collapse of Kalhoran rule in Sindh.

Economic problems were also an important factor in the Kalhoras' demise. The strengthening of Afghan hegemony in Sindh resulted in regular tribute payments to Afghanistan, and that put increasing pressure on Sindh's economy in the latter half of the eighteenth century. The chapter has documented the measures taken by the later Kalhora rulers to develop Sindh's economy, including the encouragement they 
gave to the Dutch Trading Company to trade in Sindh, and the invitation to the East India Company to open a factory in Sindh. An important issue is the social standing of the Sindhi traders and brokers in the eighteenth century; later chapters will show how their socio-political importance increased over time, and most particularly because of the roles they played as agents of the Dutch and the English traders. The next chapter makes a close study of the civil war between the Kalhoras and the Talpurs, documents the fall of the Kalhora dynasty and offers a comparison of the Kalhoran and Talpur regimes. 


\section{Chapter 3}

\section{Talpur Rule in Sindh}

Our study of Sindh in the early eighteenth century has shown that, despite their best efforts, successive Mughal governors of Sindh were not able to deal with local peasant unrest, and they had to rely on the the Kalhoras, a growingly strong and ambitious local tribe, for the effective collection of taxes. The early eighteenth century in Sindh was a period of increasing economic prosperity, a result of which was the rise in rural areas of influential merchants and powerful chiefs of tribes such as the Panwars and the Kalhoras. In the final showdown among ambitious local tribal chiefs, the Kalhoras overpowered the others and succeeded in forming a state in Sindh. This development requires that we question the arguments of historians such as Irfan Habib, Athar Ali and Satish Chandra; the eighteenth century was not a period of overall economic decline in the subcontinent. ${ }^{1}$ Government mismanagement and the decline of Mughal power in the eighteenth century gave leverage to powerful local leaders and paved the way for their emergence as state builders. Economic prosperity continued under the Kalhoras until Sindh was incorporated into the Persian (1739) and then the Afghan (1748) empires.

Political instability in Sindh during the latter half of the eighteenth century was the result of struggles among Kalhora brothers, sons of Noor Muhammed, over succession to the Sindh throne. The conflicts broke into open warfare at times and, of course, damaged the Sindh economy. Also damaging were the frequent shifts in the course of the river Indus; these shifts were responsible for frequent shifting of the state's capitals, and this added to economic instability. The weakened Kalhoran regime was overthrown by the Talpurs in 1783 .

Irfan Habib, The Agrarian System of Mughal India 1556-1707, $2^{\text {nd }}$ ed. (Delhi:Oxford University Press, 1999), M.A. Ali, 'Recent Theories of Eighteenth-Century India' in P.J. Marshall ed. The Eighteenth Century in Indian History. Evolution or Revolution? (New Delhi: Oxford University Press, 2003), Satish Chandra, 'Review of the Crisis of the Jagirdari System' in Muzaffar Alam and Sanjay Subrahmanyam, eds., The Mughal State, 1526-1750 (Delhi ; New York: OUP India, 1998), 347-360. 
The Talpurs were the murids and mercenaries of the Kalhoras. Owing to the very significant influence they wielded as the state's arms bearers, they eventually became Sindh's king makers during the later Kalhora period; under the leadership of Meer Fateh Ali Khan, they finally seized state power. The Talpurs conquest of Sindh in 1783 happened at a time when the Kalhoras were already declining as a political entity. Internecine conflict had weakened the state and it suffered significant territorial losses to its neighbours. In 1779, Umerkot was lost to Bijay Singh, the king of Joadhpur, and Karachi passed to the Khans of Kelat in 1795. When it came under Afghan suzereinty in 1748, Sindh's state finances were stretched by the requirement that it remit annual tribute to the Afghan king. Merchants in Sindh were unsettled by the frequent change of the state's rulers after Noor Muhammad's death. Subordination to Afghanistan was intensified during this phase because aspirants to the Sindh throne were dependent on authorisation by the Afghan king. This chapter will discuss Sindh's transition from Kalhoran to Talpur rule. The nature of the Sindh state under the Kalhoras was different from the form it took under the Talpurs; this difference will also be examined in this chapter.

\section{The Talpur Meers of Sindh}

The name Talpur derives from the word 'Talbur'; the meaning of 'Tal' in Sarai language means a tree branch and 'bur' means cutter. The word Talpur thus means a tree cutter, the Talpurs were known in Sindh as a tribe of shepherds. ${ }^{2}$ The Talpurs, in fact, were not a tribe or clan but a family of the Leghari clan within the Baluch tribe. ${ }^{3}$ Meer Manik Khan, the Talpurs' ancestor, migrated to Sindh with his family and a few members of his clan from Dera Ghazi Khan, north of Sindh, where there was a land shortage. ${ }^{4}$ We do not know when this migration occurred. We do know that some members of this family, when headed by Meer Shahdad, went to work for

2 Meer Khuda Bakhsh Marri, Searchlights on Baloches and Balochistan (Karachi: Royal Book Company, 1974), 196.

Ibid., 197.

Maulana Nur Ahmad Khan Faridi, urdu ed. Sindh ke Talpur hukmran: Talpur Baluchon ke ‘uruj o zaval ki ibratnak dastan (Multan: Siraeki Adabi Tahrik, 1984), 13. 
Yar Muhammad Kalhora in the early 1700s. ${ }^{5}$ The Talpurs, after arriving in Sindh, were given land in certain deradari or districts by the Kalhoras, near the region of the ancient village of Brahmanabad. ${ }^{6}$

Contemporary Persian sources do not indicate precisely when the Kalhoras first became associated with the Talpurs and when the latter became disciples or followers of the former. Meer Shahdad is mentioned in the sources as a Talpur chief who became a follower of Yar Muhammad Kalhora. ${ }^{7}$ Yar Muhammed, for his part, depended on the Talpur chief and his clan for military aid. To help the Mughal prince Muizzudin against Shah Muhammad Dodai, a defiant land holder in Dera Gazi Khan, Yar Muhammad sent Meer Shahdad Baluch to lead an armed force against Dodai. Meer Shahdad's successful campaign against Dodai led to the appointment of Yar Muhammad Kalhora as a Mughal mansabdar. Meer Shahdad was also given a jagir in the region of Pit Baran in return for his services. ${ }^{8}$

The Mughal system of appointing jagirdars and mansabdar functioned well in Sindh in the later Mughal period, and so the Mughal state was not, as J.F. Richards had argued, merely a 'hegemonic head' of the Sindh state. ${ }^{9}$ In fact, despite claims to the contrary made by Muzaffar Alam and Sanjay Subrahmanyam, ${ }^{10}$ the Mughals had control of the Sindh state's administrative system. However Mughal rule was not well established in all parts of Sindh; as indicated in Mazahar- $i$ Shahjahani, there were many instances of tribal and peasant unrest during Jahangir (the fourth Mughal emperor, 1605 - 1627) and Shah Jahan's reign $(1628-1658)^{11}$

\footnotetext{
Ibid., 14.

History of Alienations in the Province of Sind, Compiled from the Jagir and Other Records in the Commissioner's Office, on the Authority of Bombay Government Resolution no. 12, Dated $2^{\text {nd }}$ January 1878, Revenue Department ( Karachi: Commissioner's Press, 1886), 2. Justice Meer Khuda Bakhsh Bijarani Marri Baloch, Searchlights on Baloches and Balochistan (Quetta: Gosha-e Adab, 1977), 198. Ibid., 199. J.F. Richards, 'The Formulation of Imperial Authority under Akbar and Jahangir' in Muzaffar Alam and Sanjay Subrahmanyam, eds., The Mughal State, 1526-1750 (Delhi: OUP,1998), 126-167. Ibid., 12-33. Muhammad Saleem Akhtar and Yūsuf Mīrak, Sind under the Mughuls: An Introduction to Translation of and Commentary on the Maẓhar-i Shāhjahānī of Yūsuf Mīrak, 1044/1634 (Islamabad, Pakistan; Karachi: National Institute of Historical and Cultural Research ; Dept. of Culture, Govt. of Sindh, 1990).
} 
and Shah Jahan aimed to pacify local chiefs by giving them mansab in Thatta. This is a point made by Chetan Singh; he argues that local powerbrokers were appointed to the post of mansabdar under the Mughals because the Mughal mansabdars and governors were unable to check tribal unrest. ${ }^{12}$ Athar Ali, however disagrees with Singh; he says that there were many interregional appointments of governors under the Mughals. ${ }^{13}$

The appointment of Yar Muhhamad and Meer Shahdad was in line with this Mughal practice of incorporating local powerful chiefs into their administration. Meer Shahdad's sons were also given high posts under the Kalhoras. Two of them, Meer Jam Nanda and Meer Chakkar, were made military commanders, while Meer Bairam was made the Madar-ul-Muham (chief commander) and Wazir-i-Azam (prime minister) of Sindh. Meer Chakkar later founded Khairpur state in Sindh. Meer Bairam became the leader of the Talpur tribe after the death of his father, Meer Shahdad. He was at the forefront of the tumultuous court politics and civil strife that eventually undermined the Kalhoran regime, and he was instrumental in establishing Ghulam Shah as the ruler of Sindh in $1757 .{ }^{14}$

While serving at court, Meer Bairam Talpur won Ghulam Shah's confidence, and this earned him a few enemies among other courtiers; one enemy was Raja Lekhi, ${ }^{15}$ who for many years served as Madar-ul-Maham under the Kalhoras. ${ }^{16}$ Ghulam Shah died in 1772. He was succeeded by his son, Sarfaraz Khan, who continued his father's policy of attempting to extend Sindh's borders. His reign saw two unsuccessful expeditions against Cutch. ${ }^{17}$ Meer Bairam Talpur, with his influential position at court and as a leader of his tribe of Baluch warriors,

\footnotetext{
12 Chetan Singh, Region and Empire; Punjab in the Seventeenth Century, (Delhi: OUP, 1991). 13 Athar Ali, 'Mughal Policies, A Critique of Revisionist Approaches', Proceedings of Indian History Congress, New Delhi, 1992, 309-310.

14 Muhammad Lakho, Kalhora Daure Hukumat, (Reign of the Kalhoras), (Karachi: Anjuman Athad Ebasea, 2004), 249-50.

15 Captain MacMurdo, 'The History of the Kalhora Family of Sindh, Descended from Abbas, the Uncle of Mahomed the Prophet', Journal of the Bombay Branch of Royal Asiatic Society, V.1, July 1841 - July $1844,425$.

16 The internal strife at the Kalhora Court between Raja Lekhi and the Talpurs for the position of Madar-ul-Maham eventually intensified, leading to the overthrow of the Kalhoras by the Talpurs. Lakho, Kalhora Daure Hukumat, 249-50.

17 Parveen Talpur, Talpur Rule in Sindh (Lahore: Ferozsons [Pvt] Limited, 2002), 13.
} 
commanded a position of power in Sindh; he was second only to the sovereign. Raja Lekhi, set on removing Meer Bairam, persuaded Sarfaraz Khan to have him assassinated. $^{18}$

Sarfaraz Khan now supported Jam Firoz Talpur, cousin and brother-in-law of Talpur chiefs Meers Bijar and Subdar. He gave Jam Firoz a higher position in court, and this created competition and division within the Talpur tribe. ${ }^{19}$ Diwan Giddumal, agent of the Kalhoras at the Afghan court, advised Sarfaraz not to act against Meer Bairam. ${ }^{20}$ But Sarfaraz did not heed this advice and ordered that Bairam Talpur be killed. The murder of Meer Bairam led to a violent conflict involving courtiers Raja Lekhi, Meer Subdar (Meer Bairam's son) and Ghulam Muhammad Khan Laghari, a Baluch tribal chief. The Baluch chief died in a fight with Raja Lekhi in $1774 .{ }^{21}$ This enraged other members of the Baluch tribe and they attacked Khudabad. ${ }^{22}$

Sarfaraz Khan Kalhora had to flee to Hyderabad. Raja Lekhi allied with the Baluch faction headed by Meer Fateh Muhammad Khan and imprisoned Sarfaraz Khan. With the virtual power of Sindh consolidated in the hands of his clique, Raja Lekhi proposed to Meer Fateh Ali Talpur, the nephew of Meer Fateh Muhammad Khan, that the Talpurs take over from the Kalhoras as the rulers of Sindh and that he replace Sarfaraz as Sindh's head of state. This the Talpur chief refused to do because he judged it to be more appropriate to elevate another member of the Kalhora family to the Sindh throne. As a consequence, Muhammad Khan Kalhora, Sarfaraz Khan's brother, was made the next ruler of Sindh. Meer Mehrab Khan Jatoi was appointed his prime minister. The Talpurs and chiefs such as Raja Lekhi had emerged as kingmakers but, in the 1770s, they held back from usurping the Sindh throne. Until 1783, the only candidates for the Sindh kingship were people from the same family lineage as the Kalhora pirs, evidence that the Sindh tribes and society in general

\footnotetext{
$18 \quad$ MacMurdo, 'The History of the Kalhora Family of Sindh', 425. Talpur, Talpur Rule in Sindh, 13. Nur Ahmad Khan Faridi, Sindh ke Talpur hukmran: Talpur Balochon ke ‘uruj o zaval ki ibratnak dastan (Multan: Siraeki Adabi Tahrik, 1984), 20. Faridi, Sindh ke Talpur hukmran, 22. Ibid., 24.
} 
affirmed the importance of pedigree at the time. ${ }^{23}$ In other words, strict tribal norms were observed in Sindhi society and it was not easy to challenge the pre-existing tribal and social practices.

Muhammad Khan, on the advice of Raja Lekhi, imprisoned the other members of his family who aspired to the throne. However, Raja Lekhi, who had strengthened his position in the Kalhora court by arranging Meer Bairam's murder, in 1777 manouevered the dethroning of Muhammad Khan Kalhora after he had reigned for just two years and placed his own candidate, Mian Ghulam Nabi Kalhora, on the throne. ${ }^{24} \mathrm{He}$ also appointed his son Taja Lekhi (d. 1782) as the chief administrator of the Sindh's coasts. This gave Taja a key role in the management of Sindh's trade routes and traffic and, therefore, of the revenue that trade along the coast generated. ${ }^{25}$ Ghulam Nabi had maternal relatives who belonged to the powerful Juneja tribe in Sindh; apparently he was raised to the throne because Raja Lekhi had allied with this tribe. With Junejas support, Raja Lekhi could oust anyone from the court who threatened his own position. ${ }^{26}$

The 1777 murder of a Talpur chief provoked members of the Baluch tribe to mobilise the Baluchi component of Meer Bairam's supporters and to seek revenge by overthrowing the Kalhora dynasty. Meer Bijar, another of Meer Bairam's sons, was away on a pilgrimage to Mecca when the the murder of his father took place. When he returned to Sindh, the Talpurs and other Baluch chiefs decided to attack Ghulam Nabi. ${ }^{27}$ The ruler of Kelat, Naseer Khan, offered help to the Talpurs against the Kalhoras, but Meer Bijar did not accept this help because he had heard that Raja Lekhi was allied with Naseer Khan. ${ }^{28}$ However, Raja Lekhi died at this point, and his son Taja Lekhi succeeded to his positions at the Kalhora court. ${ }^{29}$

Ibid., 24.

Ibid., 24.

Ibid., 14.

Ibid.

Ibid.,2.

Talpur, Talpur Rule in Sindh, 14. Ibid. 14. 
An armed conflict between the Talpurs and Kalhoras took place in 1778. The Kalhoras were defeated, and so Ghulam Nabi now decided to pacify the Talpurs. ${ }^{30}$ He sent a letter to Meer Bijar in which he suggested that they meet to discuss an alliance. Meer Bijar did meet with Ghulam Nabi in Hyderabad, but he was now ill and close to death. The two chiefs regretted the differences that now existed between their tribes. Ghulam Nabi suggested to Meer Bajar that his brother Abdul Nabi Kalhora should succeed him as the ruler of Sindh. Taja Lekhi was hostile to the Talpurs, and when he learned that Ghulam Nabi wanted a rapprochment with Meer Bijar, he attacked and killed Ghulam Nabi in $1778 .^{31}$

Meer Bijar, now in a position of being the virtual ruler of Sindh, shifted his headquarters to the newly founded town of Khudabad. He then asked Abdul Nabi Kalhora, who was in Hyderabad, to come to Khudabad to be enthroned as Sindh's ruler. Accordingly, Abdul Nabi succeeded Ghulam Nabi to the Sindh throne, and then executed his relatives Sarfaraz Khan and Sarfaraz's sons, Mohammed Khan and Attar Khan. His rule saw a further decline in Sindh's revenue, requiring that payment of tribute to Afghanistan be withheld. The Afghan king, Timur Shah, wanted to curb the growing influence of the Baluchis in Sindh, and the revenue arrears gave him a pretext to do this. Izzat Yar Kalhora, the cousin of Abdul Nabi and grandson of Khudadad Khan, was in the Afghan court as a hostage at the time. The Afghan king decided to put Izzat Yar on the Sindh throne. ${ }^{32}$

Izzat Yar Khan, supported by an army made up of Durani and Babri Afghans, marched on Khudabab to unseat Abdul Nabi Kalhora. The Afghan agent in Dera Ghazi Khan and Ismail Khan were instructed to fund the expedition from the revenues generated from Dera Ghazi Khan and to recruit additional troops consisting of Afghans and Baluchis. Orders were also issued from Afghanistan to the governors of Multan, Shikarpur, Bahawalpur ruler and Brauhis to help Izzat Yar Khan. Khosas tribesmen, who were rivals of the Meers, also joined the army sent from Afghanistan.

Ibid. 14.

Faridi, Sindh ke Talpur hukmran, 27.

Mirza Kalich Fredunbeg, A History of Sindh, Vol. II, 2 ed. (Karachi: Scinde Classics, 1982), 176. 
${ }^{33}$ When the expedition reached Sindh, Izzat Yar Khan asked Meer Bijar to accept him as the new ruler, appointed by Afghanistan, and to give him their allegiance. Meer Bijar, however, refused this request and repulsed Izzat Yar Khan's forces with an army of Baluchis led by Abdul Nabi Kalhora. ${ }^{34}$

This defeat compelled Timur Shah to himself lead an expedition against Sindh. When he reached Shikarpur, Abdul Nabi and Meer Bijar decided not to fight him and instead presented a letter in which they offered the Afghan king their allegiance. They also helped Timur Shah's army cross the river Indus at Lahori by providing his army with boats. This gesture appeased Timur and he allowed Abdul Nabi to remain on the Sindh throne. Abdul Nabi now wanted to rid his court of the Talpur chief, Meer Bijar, and to achieve this he tried to secure help from Timur Shah. ${ }^{35}$ Abdul Nabi Kalhora's mother, from the tribe of Junejas, had considerable influence at the court of the Sindh ruler; with Raja Lekhi's help, she appealed to Bijay Singh, the ruler of Jodhpur, offering him the province of Umerkot in return for his help. ${ }^{36}$

The relations between the Talpurs and Rajputs were also strained, because the Talpurs made several forays into the Umerkot deserts and had built a fort there called Meer Garh. Because Bijay Singh wanted to curb Talpur influence in Sindh, in 1781 he sent two Rathor Rajput envoys to Sindh. They treacherously killed Meer Bijar. Abdul Nabi subsequently ceded Umerkot to Bijay Singh. But Meer Bijar had many admirers and supporters both within and outside his tribe. He was also respected by many of Sindh's Muslims because he was a haji (a pilgrim to Mecca), which in those days gave him the status of a highly respected person in society. His murder, therefore, had major consequences. Meer Bijar's son, Meer Abdullah, who was away at Shahdadpur during his father's death was made the successor of Meer Bijar by the Talpurs. ${ }^{37}$

\section{Ibid. 176.}

Ibid., 177.

Ibid., 178-179.

Talpur, Talpur Rule in Sindh, 16. Ibid., 16. 
Abdul Nabi fearing a revenge of the Talpurs against him fled to Kelat and sent his two sons to Jodhpur. The Talpurs now showing their support to Abdul Nabi asked him to be beware of their rivals and strangers (they had the Rajputs in mind) and asked him to return to Sindh. Abdul Nabi, however, decided not to trust the Talpurs and continued to gather help against them from Kelat and Jodhpur. ${ }^{38}$ All chiefly members of the Kalhora family of pirs were murdered. This made the Talpurs decide to place on the Sindh throne a sage and a kinsman of the later Kalhora rulers, Sadiq Ali. ${ }^{39}$ Having no experience in statecraft, Sadik Ali was merely symbolic head of state. Meer Abdullah Khan remained in actual charge of state governance and he tried to improve Sindh's much neglected administrative and economic affairs. He abolished certain old and cumbersome practices of the Kalhora court such as the obligatory offering of presents to the ruler (peshkash). The poll-tax (sar shumari) was also abolished. These measures won Abdullah Khan many supporters in Sindh. ${ }^{40}$

Abdul Nabi, in the meantime, had won the support of the rulers of Jodhpur and Kelat, and they sent armies against Sindh's Talpur faction. ${ }^{41}$ The Talpurs however repelled these forces, and so Abdul Nabi Kalhora appealed to Afghanistan for help. To strengthen his case he paid part of the tribute that Sindh owed the Afghan king, and promised payment in full after the victory. Timur Shah again sent an armed force to Sindh, but this time it was to help Abdul Nabi Kalhora against the Talpurs. Mahfuz Khan, the Kalhora's agent at the Afghan court, persuaded Timur Shah to ask the ruler of Kelat to send a militia made up of Brauhis and other Baluchis, against the Talpurs. In return, Abdul Nabi would allocate to the ruler of Kelat some territory in Sindh and make a payment of three lakhs of Rupees in return to the ruler of Kelat. ${ }^{42}$

Ibid., 17.

Fredunbeg, A History of Sindh, 181.

Faridi, Sindh ke Talpur Hukmran, 38.

Talpur, Talpur Rule in Sindh, 37, Fredunbeg, A History of Sind, 178-179. Faridi, Sindh ke Talpur Hukumran, 39, Fredunbeg, A History of Sindh, 183. 
And so armies of Afghanistan and Kelat were dispatched to join Abdul Nabi's army. The Baluchs of Jatoi, from Mehrab and Dhunganah, and members of the Nuhmardi, Khosah and Jhinjan tribes, also joined the forces assembled by Abdul Nabi Kalhora. ${ }^{43}$ When this army reached Sindh, it unleashed mayhem and terror. ${ }^{44}$ The Talpur Meers again pushed back this army; nevertheless Abdul Nabi Kalhora again appealed to them to make him Sindh's ruler, and this time he prevailed. Sadiq Ali Khan was replaced by Abdul Nabi. In order to strengthen his position, Abdul Nabi, just three days after his accession to the Sindh throne, arranged to have the Talpur Meer Fateh Muhammad Khan murdered. Instead of relying on the Talpur chiefs, he tried to use the Jattoi tribe as his support base. So Dhangana Jattoi was made Mukhtar-i-Amir and was alloted the region of Lakhawat as jagir. ${ }^{45}$

The Talpurs now elevated Meer Fateh Ali Khan (Meer Fateh Muhammad Khan's nephew) to leadership of the tribe, and went to battle against Abdul Nabi. The intention this time was to overthrow the Kalhora regime, and this happened after a battle between the two tribes at Halani in 1782. The fort of Hyderabad was occupied with the help of the Legharis, a tribe that later became the Talpur Meers'principal allies and holders of several administrative posts in the Talpur administration. ${ }^{46}$

Meer Fateh Ali chose to continue with the tribal practice of dividing income among his family and kinsmen. For the purpose of revenue collection, he divided Sindh into five fiscal units. He headed one of them himself, and another two were for his three brothers - Meer Ghulam Ali Khan, Meer Karim Ali Khan and Meer Murad Ali Khan. A fourth unit was allotted to Meer Sohrab, a member of his extended family, and the fifth - to Meer Thara Khan. This division of revenue management was not acceptable to Meer Sohrab and Meer Thara Khan, and Meer Sohrab decided to protest. He went to Rohri, raised an army there and founded the state of Khairpur,

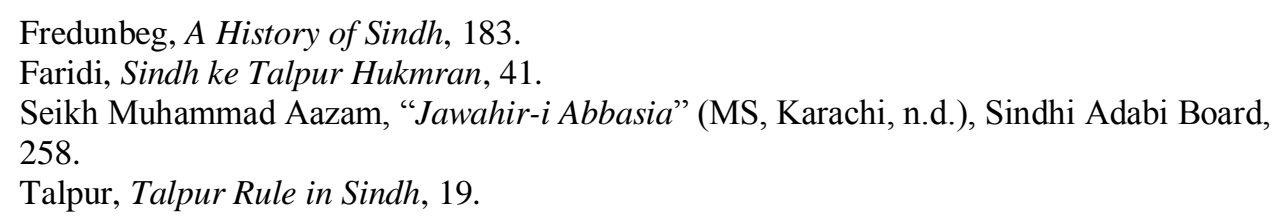


declaring himself to be independent of the Hyderabad regime. Meer Thara Khan also left Hyderabad and founded the state of Mirpur at Shah Bundar where he too declared his independence. As we can see, Sindh at this point was far from unified; it consisted of several autonomous and semi-autonomous tribal polities.

Abdul Nabi Kalhora had by no means accepted defeat, and travelled to Kabul to ask Timur Shah for a sanad (royal decree) of rule in his favour. But Meer Fateh Ali's envoy to Kabul had delivered to Timur Shah a payment of the tribute that Sindh owed to the Afghanis, and so the Afghan king gave his support to the Talpur regime. ${ }^{47}$ Another attempt to restore Kalhora power in Sindh was made by Ali Mardan Khan, Abdul Nabi's grandson; he appealed to the East India Company to help him win the Sindh throne. The British at the time had no interest in Sindh affairs and turned down the request. ${ }^{48}$

And so all attempt at a Kalhoran restoration failed. The four rulers of Hyderabad, including Meer Fateh Ali Khan and his brothers Meer Ghulam Ali Khan, Meer Karam Ali Khan and Meer Murad Ali Khan ruled harmoniously together although Meer Fateh Ali Khan was the principal Meer among them. They were known as 'chaho yar', or the four friends; they were equated with 'Khalifa-iRashidun', the four caliphs who were the friends of Prophet Muhammad and who, after $632 \mathrm{CE}$, succeeded the Prophet as leaders of the Muslim world. ${ }^{49}$

Meer Fateh Ali died in 1802 and was succeeded by his brother, Meer Ghulam Ali as the principal Meer. After Ghulam Ali's death, the two surviving brothers, Meer Karim Ali and Meer Murad Ali, ruled jointly; both their names appear on the sanads that they issued. ${ }^{50}$ After Meer Murad Ali Khan's death in 1831, his territorial posssessions were again divided into four parts, administered by four amirs: Meer Sobdar (son of Meer Fateh Ali Khan), Meer Muhammad (son of Meer Ghulam Ali),

Ibid. 19. Ibid., 20-21. Faridi, Sindh Ke Talpur Hukumran, p. 68. The four caliphs were Abu Bakar, Umar, Usman and Ali. History of Alienations, 3-4. 
Meer Noor Muhammad and Meer Naseer Khan (son of Meer Muard Ali) ${ }^{51}$ Khairpur was also divided into five revenue units; one was allocated to two of Sohrab Khan's six sons after his death in 1830, and one to each of the other four sons . In Khairpur as well, after the death of their father in 1828, Meer Tharra Khan's three sons divided the region between them. ${ }^{52}$

Meer Noor Muhammad, one of Meer Muard Ali's sons, had divided his territory equally among his two sons Shahdad and Hasan Ali. Shahdad, with the help of his clique (which included influential Baluch chiefs of the Hyderabad court), wanted to commandeer his brother's possessions and privileges. Hasan Ali, however, had his own supporters among the Baluchis, including Nawab Ahmed Khan Leghari, a Baluch. As will be shown in chapter 4, the internal rivalry among the Talpur chiefs gave the British an opportunity to intervene in the internal politics of Sindh. The chiefs of the various Baluchi clans, with whose help the Talpurs had unseated the Kalhoras, were also quite autonomous, and the Talpur Meers had to acknowledge this. In fact, a kind of tribal confederacy of Baluchis evolved in Sindh. Meer Shahdad himself mentioned to a British officer that Jan Khan, one of the tribal chiefs who worked under him, had attempted to poison him twice, but he could not take any action against him because he was from a very powerful clan. ${ }^{53}$ Local politics in other parts of India at the time, places such as Awadh and Carnatic, were also riddled with conflict. We can say that inter-family feuds, tribal rivalries, sedition and political unrest were characteristic features of the eighteenth century polity in India generally; Sindh was by no means exceptional in this respect.

However, Edward Eastwick, who served as a British official in Sindh from 1839 to 1841 , observed that during the sixty-years of Talpur rule in Sindh (17831843), there was no serious attempt to overthrow the Talpur Meers; this contrasts with the insecure position of the Khalsa rulers in neighbouring Punjab where challenges to the regime almost occurred every year. ${ }^{54}$ Unlike their fellow tribesmen

Ibid., 5.

Fredunbeg, A History of Sindh, 221.

Ibid., 221.

Ibid., 200. 
in the Pubjab, the Baluchis in Sindh, constituting one-third of the population, remained loyal to the Talpurs in their struggles with the British because the Talpur Meers were sensitive enough to not infringe on their privileges. ${ }^{55}$ The Baluchis feared that they would lose their position of privilege if the British unseated the Talpurs. At the Talpur court it was only Sayyid Ismail Shah and his family who withdrew their support from the Meers. This family had relocated from Persia to Sindh after Nadir Shah's invasion, and they felt insecure under the Talpurs, fearing that they could lose possession of the large tract of land they possessed in Sindh. ${ }^{56}$

\section{Administration and society under the Kalhoras and Talpurs}

After the Kalhoras replaced the Mughals as Sindh's rulers, the state's administrative apparatus gradually changed, although very slowly at first. The most significant change was under the later Kalhoras who relinquished their role as sufic pirs and, thus, the piri-muridi (master-disciple) type of relationship between rulers and their subjects. There was further change during the succession wars of the 1760s and '70s and it could be seen in the changes in official nomenclature and in reorganisation of the units of land revenue administration. Under the Mughals, Sindh had been divided into two Subas (administrative units) - Multan and Thatta; the head of a suba was a Subedar. Mian Noor Muhammad Kalhora was given the suba of Thatta by the Mughals, but after this the head of Thatta was called Nazim, not Subedar. The administrative unit below a Suba was a sarkar headed by a Faujdar. Under the Mughals the political unit below a sarkar had been a mahal (or pargana), the head of which was a Shiqdar. The lowest administrative unit was called a mauza; this was a village under the governance of a Haqim or Arbab. The Arbabs were the intermediary zamindars or landlords. Noor Muhammad changed the names of some administrative units; for example, instead of Mahal (revenue unit) he used the term Zila. During Ghulam Shah Kalhora's time, Mahal was called Talluqa. ${ }^{57}$ Thus the of Sir Charles Napier. By an Ex-Political [i.e. E.B. Eastwick] (London: James Madden, 1849), 202.

$56 \quad$ Ibid., 202.

$57 \quad$ Faridi, Sindh Ke Talpur Hukumran, 247. 
administrative structure put in place by the Kalhoras drew on the Mughal system but also changed it. In this respect it was different from other successor states that had broken away from the Mughal state in the eighteenth century, namely Awadh, Bengal and Hyderabad.

The office of Madar-ul Maham (Prime Minister) under the Kalhoras remained in place when Raja Lekhi held the office in the 1770s and during the Baluch Talpur dynasty after 1782. The only exception was when Noor Muhammad gave the Prime Ministership to his son Muhammad Murad Yab Khan. Before the Kalhoras came to power, the term 'Waqil' was used for 'Wazir', or ruling elite, but the new word signified a new role in the eighteenth century. Now the Waqil were 'Safir' (envoys) of the state. ${ }^{58}$ The position of Diwan, or head of the revenue and justice department, was generally held by Hindus of the Amil caste and we have reference to some of them holding this post; for example, Diwan Chelaram Sehwani and Diwan Giddumal. However, Noor Muhammad, in his instruction to his son in his will, warned him to be careful of the Hindu Munshis (accountants). ${ }^{59}$

The position of the Hindus in the Talpur administration is crucial for understanding the economic developments of this period. In his 1829 account of Sindh, Englishman James Burnes blamed the Talpur Meers for the decline of commerce in Sindh, and attributed the decline to their discrimination against the Hindu merchants. ${ }^{60}$ It is true that some industries, such as cloth making in Thatta, declined during the Talpur period, but this is not necessarily attributable to the Meers' treatment of Hindus. Hamida Khurro, in his Introduction to Burnes' book, suggested that the decline of industries can be explained by changes in people's tastes and, hence, changes in what they buy at markets. The demands for luxury goods by the ruling class contributed to changes in demand. ${ }^{61}$ And the opium trade made up for shortfalls in other sectors of the economy; the Talpur Meers allowed the opium

\footnotetext{
$58 \quad$ Ibid., 251-252.

$59 \quad$ Ibid., 250.

60 James Burnes, $A$ Visit to the Court of Sindh, with an introduction by Hamida Khurro (first published by Summarchar Press, Bombay, 1829, and John Stark, Edinburgh, 1831; republished by Oxford University Press, Karachi, 1974).

61 Hamida Khurro, 'Introduction to Burnes', A Visit to the Court of Sindh, xvii.
} 
traders to pass through Sindh because the trade earned them revenue. Writing in 1836, Captain J.F. Heddle remarked that the amirs were 'vigilant' and 'well ordered' enough to protect commerce and agriculture for their own interest, and he observed that state laws were well observed by the people. Overall he considered Sindh to be one of the most advanced civilizations in the region between 'the Indus and the Euphrates'. ${ }^{62}$ We can see, therefore, that other foreign observers disputed James Burnes' use of words such as 'tyrannical' and 'oppressive' to describe the Talpur Meers; Hamida Khurro suggested that it was the Victorian Englishman's lack of understanding of Indian society that led to such negative judgments. ${ }^{63}$ EIC officer Charles Masson, who visited Sindh in 1830, observed that there were no acts of 'cruelty or exactions' in Sindh. Rather the Meers provided security and 'freedom' to their subjects. ${ }^{64}$

\section{Economic conditions under the Kalhoras and Talpurs}

As a frontier region positioned between India and Khorasan, with Persia and Afghanistan as near neighbours, Sindh's economic history makes a fascinating case study. Trade between central Asia and India was often routed through Sindh and, as a consequence, was connected with the world trading economy. Situated on the Arabian Sea, one of the major trading nodes of the world trading system, Sindh had well established trading relations with Surat and Diu on the Gulf of Cambay in Gujarat, and with Muscat, Hormuz and the Persian Gulf. Sindh had a thriving trade with Muscat and many Sindhi traders did not have to pay customs fees there. ${ }^{65}$ Lahari Bundar, situated at the mouth of Indus, was a major Sindh port in the seventeenth century. Goods from here were shipped along the Indus river to Thatta's

J.F. Heddle, 'Memoir on the River Indus (May 1836)', Selections from the Records of the Bombay Government, no. XVII, n.s. part ii. In James Burnes, A Visit to the Court of Sindh, xix. Hamida Khurro, 'Introduction' in Burnes, A Visit to the court of Sindh, xiv. Charles Masson, Narrative of Various Journeys in Balochistan Afghanistan and the Punjab. (London: Richard Bentley, 1842), Vol.ii, 463.

R.J. Barendse, The Arabian Seas: The Indian Ocean in the Seventeenth Century (New York: M.E.Sharpe, 2002), 50. 
markets. ${ }^{66}$ Historians have taken a keen interest in Sindh's economy and society in this period, and the following discussion draws on recent research on the subject.

The Sindhi Hindu traders of the Bania caste controlled a major sector of trade in the Persian Gulf region. ${ }^{67}$ The involvement of both indigenous and foreign traders led to the evolution, beginning in the sixteenth century, of the complex market-based economy in Sindh that we find in the seventeenth and eighteenth centuries. The Portuguese trading company, Estado da Índia, had operated a factory in Lahri Bunder since the sixteenth century, and it carried textiles and low-cost household goods from Sindh to Persian Gulf countries. ${ }^{68}$ Sindhi textiles fetched good prices in Persia, and Portuguese and Sindhi traders made huge profits from this foreign trade. ${ }^{69}$ The vigorous and lucrative trade system between India and the Middle East that we find in the seventeenth century was a continuation of trading systems of the ancient world, and these systems survived well into the period when Europe was industrialised. ${ }^{70}$

As noted in chapter 2, although trading centres such as Thatta were in decline by the eighteenth century, new commercial hubs such as Shikarpur, Hyderabad and Karachi were emerging. And Thatta did not completely die as a trading port; its Hindu merchants from Bhatia caste still dominated the trade with Muscat and also looked for trade outlets in the Bahrain islands. ${ }^{71}$ Hyderabad, a port city established by the Kalhoras in 1769, was made the capital by the Shahdani branch of the Talpur ruling family, mainly to get further away from the Afghan rulers who were ever ready to demand tribute from Sindh. Hyderabad's growing importance as both a political and commercial centre attracted bankers, financers, merchants and and Ashin Das Gupta ed. India and the Indian Ocean: 1500- 1800, ed. (New Delhi: Oxford University Press, 1999), 98.

$67 \quad$ Ibid., 5.

68 William Floor ed., The Dutch East India Company (VOC) and Diewal-Sind (Pakistan) in the $17^{\text {th }}$ and $18^{\text {th }}$ Centuries: Based on Original Dutch Records, (Karachi: University of Karachi, 1993), 10. Ibid., 10.

Barendse, The Arabian Seas, 7. Claude Markovits, The Global World of Indian Merchants, 1750-1947: Traders of Sind from Bukhara to Panama, (Cambridge: Cambridge University Press, 2000), 54. 
craftsmen to the Talpur capital. As noted above, the Talpur Meers welcomed the revenue earned from the opium transported through Sindh. Karachi emerged as an important opium entrepôt on the route between Malwa and China, and the Sindhi banias were active in supplying the caravans for the trade. They also acted as agents in remitting transit duties to the custom officers in Sindh. ${ }^{72}$ Shikarpur, taken by the Talpurs from the Afghans in 1824, also attracted the interest of the British due to its trade with central Asia through the Bolan pass.

The Shikarpuri shroff (bankers) financed much of the central Asian trade and issued shikarpuri hundis (bills of exchange). The Shikarpuri merchants in Karachi also took part in the Malwa opium trade that was routed through Sindh; most of Shikarpur's merchant were from the Khatri community. In the 1830s the British were keen to establish links with the dynamic trading network centered on Shikarpur. ${ }^{73}$ In chapters 4 and 5 we will see how internal feuds among the Talpur Meers resulted in the British occupying Shikarpur in 1839. We will also see how Sindhi merchants helped the British to establish themselves as a political power in Sindh because they expected the British to serve mercantile interests better than the Talpurs did.

The Hindus from the Lohanas, Khatri and Bhatia communities were engaged in trade and resided mainly in the cities. In the rural areas, the Muslims were waderos or Zamindars (land holders) who either cultivated their own land or got it cultivated through cultivators having hereditary rights over land to cultivate. Most of the Baluchis served as military retainers of the Meers. Most of the non-Baluchis in the villages were either cultivators or artisans. ${ }^{74}$

S.P. Chablani argues that irrigation systems under the Kalhoras were more efficient than under the Talpurs; the Kalhoras were famous for increasing cultivatable land area by constructing irrigation canals. Noor Muhammad Kalhora, who was the subadar of Sindh under Mughal rule in 1719, constructed the famous

Ibid., 41.

Ibid., 64.

Burnes Report, A Selection from the Records of Bombay Presidency, 725-727. 
Nur Wah canal. His ministers constructed many other canals such as the Shah ji Kur, Date- ji-Kur, Nasrat Wah, Bag, Pheroz, and Murad canals. In the 1770s, Sarfaraz Khan constructed a canal in Hyderabad called Sarfaraz Wah. When the Talpurs divided Sindh into three subdivisions, the maintenance and development of the canal system of irrigation were neglected. They nonetheless constructed small canals within their territories and each canal was named after the Meers who constructed them with Wah as suffix. ${ }^{75}$

The Mughal system of tax collection underwent a change in Sindh during the Kalhoran and Talpur periods. The Mughal system depended on regular revenue from the regions under its dominion to maintain courtly grandeur and royal extravagance. Under the Mughals the revenue system in the Suba of Thatta, was based on ghallabakshi or batai, that is, crop-sharing. The ghalla-bakshi system was introduced in Sindh by Akbar (1556-1605) and, according to Mazahar-i-Shahjahani, continued until the seventeenth century. ${ }^{76}$ This provides evidence that Sindh in this period remained a part of Mughal India's economic nexus and continued the Mughal revenue system. ${ }^{77}$ Land taxes constitued fifty percent of crops harvested each year. Feroz Ahmed argues that the Mughals in the later phase of their rule in Sindh, exacted from the peasants more than half of total crop production, and this led to a good deal of peasant unrest. $^{78}$

Khasgi was a common method of revenue collection under the Kalhoras and the Talpurs. It entailed the collection of taxes in kind and according to a fixed rate per bigha of land. For grain crops, land revenue was assessed on the basis of batai; in the case of non-grain crops, mahsuli (cash) was collected. District officers (Kardars) usually inspected (nazar-deed) the crops before fixing the amount of tax to be paid in grain. Other methods of tax assessment were kankut (estimation of 1951), 28-29.

76 Sunita Zaidi, 'Akbar's Annextion of Sindh-An Interpretation' in Irfan Habib ed. Akbar and his India (New Delhi: OUP, 2004), 30-31.

77 ibid., 30-31.

78 Feroz Ahmed, 'Agrarian Change and Class Formation in Sindh', Economic and Political Weekly, Vol 19, No. 39, Sep. 29, 1984, 150. 
grain to be collected per bigha of premeasured land) and charkhashumari (counting of the Persian wheels). ${ }^{79}$ The cultivators who were unable to pay the taxes they owed often took loans from the Bania moneylenders in the villages. The Hindu Banias worked in tandem with the local Baluchi groups who also gave them military protection. The cultivators also paid the village headmen a part of the produce from their land, this was called Wajah. As well as land tax there were another nineteen different types of taxes levied by the Kalhora and Talpur regimes.

The Kalhoras favoured the Mughals' jagirdari system. But they departed from the Mughal practice of regularly transferring jagir holdings and, instead, made them hereditary. Their purpose was to encourage the jagirdars to put more effort into agricultural improvement and thereby achieve higher crop yields. As a consequence, the Kalhoras' support base was in the countryside where there was now a system based on permanent jagir holdings. The Talpurs, whom they incorporated into the Kalhoran body politic, were remunerated with grants of seri (green cultivated crops) grown on certain bigha ${ }^{80}$ of cultivated land, for six months or one year within their deradaris. ${ }^{81}$

The Kalhoras, like the Mughals, patronised religious leaders such as sufi pirs and Sadaat by giving them revenue-free land grants (madad-i-maash). EIC sources make mention of Ghulam Shah Kalhora renewing the land grant made to a saiyid by the name of Meer Yacoob Khan in Bukkhar, ${ }^{82}$ a grant that had previously been renewed by Shah Jahan in the seventeenth century. The Zamindars of Bukkhar were found to be indebted to the Hindu Banias who, as noted above, were mainly usually the village moneylenders. ${ }^{83}$ The traders based in Sindh's towns were also mainly

\footnotetext{
$79 \quad$ Ibid., A-153.

80 A bigha is a unit of land measurement which varied in different regions. During the reign of Akbar a bigha was 0.59 acre of land. During Shah Jahan's reign, this unit of measurement was changed for revenue collection purposes. Now a new kind of bigha, called bigha-i-Ilahi, was used; it was equivalent to $2 / 3^{\text {rd }}$ of a bigha. Irfan Habib, Agrarian Changes in Mughal India 1556-1707, $2^{\text {nd }}$ ed. (New Delhi: OUP, 1999), 3.

$81 \quad$ History of Alienations, 2.

82 R. Hughes Thomas, Memoirs on Sind, Selection from the Records of the Bombay

83 Government, no. XVII-New Series, Vol. 1, $2^{\text {nd }}$ ed. (Karachi: Karimsons, 1979), 79. Ibid., 80 .
} 
from the Hindu caste of Banias and remained independent of the Kalhora state's direct control. ${ }^{84}$

Unlike the Mughal system, the jagirdars under the Talpurs were not required to maintain their own armies and relied on their Baluch warlords for a regular army. ${ }^{85}$ In return the warlords were also given jagirs. Meer Ghulam Ali annulled many seri assignments; under him significant areas of seri land were converted into jagir land. ${ }^{86}$ There were considerable increases in jagir land when he was Sindh's ruler, not so much because new grants of jagir land were made but through conversion of seri land to jagir. ${ }^{87}$ There was also a drop in state revenue because of the increase in the number of land grants. ${ }^{88}$ Under Meer Murad Ali and Meer Karim Ali, the practice of converting seri assignments to jagir holdings continued; as a result, by the end of the Talpur period, hardly any seri land existed. ${ }^{89}$ Jagirs were not tied to specific places; they could be relocated to accord with harvest seasons (fasl ba fasl). ${ }^{90}$ In this respect the Talpurs retained the flexibility of the Mughal system. A new development in the later Talpur period, however, was the replacement of jagir grants with cash payments. ${ }^{91}$

The jagirdars of Sindh belonged to different social classes. The Hyderabad jagirdars were different from those of Shikarpur. As noted ealier, the Talpurs took Shikarpur from the Daudputras in 1824, and the jagirdars here were people who had been granted jagir by the Afghan rulers. They were either administrators, or religiousleaders, or members of the ruling elite. They were given a tract of land, known as pattas, for cultivation and were called pattadars. The pattas were granted on a permanent basis. Unlike the Hyderabad jagirdars, they were not required to

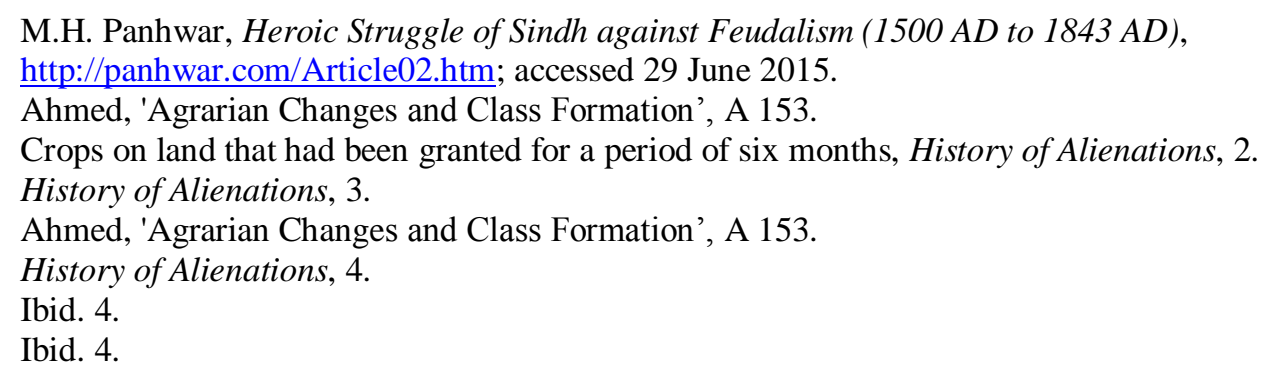


provide military support to the Talpurs in return for the jagir grant. ${ }^{92}$ Some of the Hyderabad jagirdars were members of the ruling family while others had the status of village watchmen. ${ }^{93}$ Many of them had to attend the Talpur court; as courtiers they had duties to perform in the service of the Talpurs. Away from court, in their jagir, they had some authority to settle civil cases. Criminal cases that did not involve state interests were settled either by the jagirdars or by their kardars. The cases that involved interpretation of shariat were settled by the qazis (judges). ${ }^{94}$

The size of the jagirs also varied. Some were quite small, yielding just a sum of Rs. thirty annually. ${ }^{95}$ Because the granting of jagirs increased under the Talpurs, the land revenue collected by the Talpur state declined. Land revenue collected by the Mughals was Rs. 2.17 million annually; it increased to an average of Rs. 5.33 million per year under the Kalhoras; it dropped under the Talpurs to an average of Rs. 4.6 million per year. ${ }^{96}$

Noor Muhammad Kalhora had to make a tribute payment of Rs.twenty lakhs (1 lakhs $=100,000)$ annually to Nadir Shah. Until Ghulam Shah Kalhora's reign, this tribute was collected regularly by Afghan ruler Ahmed Shah Abdali; collections became irregular after his death in 1772, but demands for payment were regularly made. To meet the demands, Sarfarz Khan used the strategy of previous Kalhora rulers; that is, he attempted to extend Sindh's borders (and, therefore, its revenue base) by waging war against Cutch, and also by lifting agricultural production by building irrigation systems. ${ }^{97}$

Annual payment of tribute to Afghanistan was a drain on the Sindh economy; the Talpurs inherited this and other financial problems when they took over from the Kalhoras in 1783. Shah Zaman, the then ruler of Afghanistan, compelled the Meers in 1794 to pay $£ 2,400,000$ (Rs. $988,235,304$ ), the amount of tribute that Sindh owed

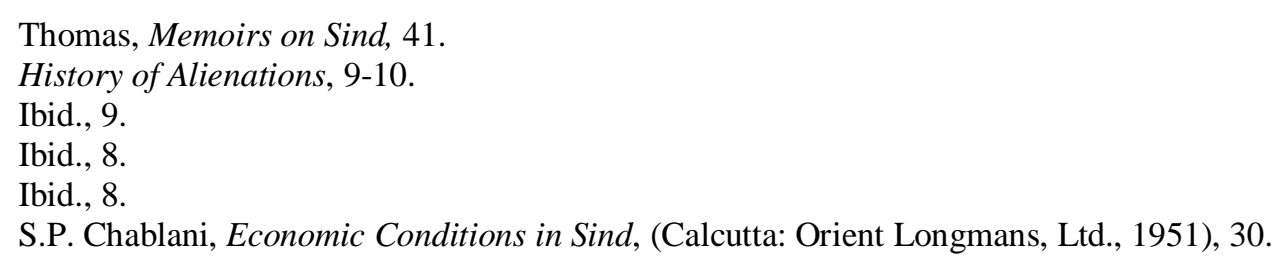


Afghanistan. ${ }^{98}$ Nathan Crow, the EIC's political and commercial agent in Sindh at this time, estimated that Sindh's annual income in 1799 was Rupees forty lakhs. Of Sind's annual income of Rupees forty lakhs, Hyderabad (under Meer Fateh Ali) received Rupees twenty-five lakhs, Khairpur (under Meer Sohrab) received Rupees eleven lakhs, and Mirpur (under Meer Thara) received Rupees six lakhs.

The Meers had agreed to pay Rupees ten lakhs as annual tribute to Kabul. To raise this sum, Meer Fateh Ali consented to contribute Rupees six lakhs, fifty thousand, and Meer Sohrab and Meer Thara together paid a total of Rupees three lakhs, fifty thousand. The Meers, however, were reluctant to hand over the tribute owed to Kabul, and Afghanistan managed to collect it only twice, in 1804 and 1809. On both occasions it was exacted by Shah Shuja, the ruler of Afghanistan in those years. The tribute arear exacted from the Meers in 1804 was Rs. seventy lakhs $(£ 170,000) .{ }^{99}$ The amount of tribute exacted by Kabul in 1809 is not known.

In 1818 Muhammad Azim Khan, the then ruler of Afghanistan, wanted to recover tribute debt that Sindh had accumulated and sent to Khairpur an army of 20,000 under the command of Mudat Khan. The Talpur Meers at first planned a military defence against the Afghans, but they were persuaded by the ruling elite Nawab Wali Muhammad Laghari to negotiate the matter peacefully with Mudat Khan. Wali Muhammad Laghari took a firm stand with Mudat Khan, telling him that Afghanistan was now a weak country, without allies, and his army could not match Sindh's Baluch force of seventy thousand men. He proposed that it was better, therefore, that he return with just a nalbundi (road expenses) of Rupees two lakhs. Mudat Khan had to agree to this; he was paid Rupees one lakh immediately, and the rest would be remitted after his return to Kabul.

According to Eastwick, Sindh's annual income in 1839 was Rupees fiftyseven lakhs: this was distributed in varying amounts to Hyderabad, Shikarpur and Mirpur. The Meers of Shikarpur took twenty lakhs, the five amirs of Hyderabad shared thirty lakhs, and the remaining seven lakhs went to the Meers of Mirpur. 
Eastwick says that the annual income of each Meer of Hyderabad was less than that of a minor English nobleman. ${ }^{100}$ But given that the cost of living in Sindh was lower than in England at the time, incomes and living standards in Sindh and England cannot be usefully compared. ${ }^{101}$ Chablani argues that agricultural productivity in Sindh increased during the late-Mughal to early-Kalhora period, but decreased in the Talpur period. While the total area under cultivation at the end of the Mughals' reign was 16.5 lakhs acres, under the Kalhoras it rose to 21 lakhs acres and under the Talpurs fell to about 8.3 lakhs acres. Because the acreage used as hunting grounds increased under the Talpurs, the total area under cultivation shrank. The Talpur Meers' frequent grants of jagir lands to the Baluchi chiefs further reduced the total area of cropland. Consequently land revenue, which in the Kalhora period was Rs. 53.3 lakhs per year, fell to to Rs. 30.7 lakhs per year under the Talpurs. ${ }^{102}$

The Hindu merchants constituted the most prosperous sector of the Sindh population; they were based mainly in the commercial towns of Shikarpur and Hyderabad. ${ }^{103}$ Although the Talpurs had hampered local commerce by imposing various transit taxes (ser or rahdar mahsul), the Hindus had business stakes in Sindh and so were disinclined to pack up and move somewhere else. ${ }^{104}$

Seth Naomal Hotchand, a prominent Sindh merchant of whom we'll hear more, recorded in his autobiography that his family had been a victim of the 1831 Hindu-Muslim communal riots in Sindh; this estranged him from the Talpur regime and was a reason why he supported the British annexation of Sindh. ${ }^{105}$ Although initially Sindh's merchants did not necessarily endorse the imperial and economic ambitions that drove British expansion in their region, the Hindu traders, and especially Seth Naomal Hotchand, came to favour the British because they were

\footnotetext{
$100 \quad$ Ibid., 197.

101 John Wood, Journey to the Source of the Oxus, $2^{\text {nd }}$ ed. (Karachi: OUP, 1976), 25-6.

102 Chablani, Economic Conditions in Sindh, 42-49.

103 Burnes, A Narrative of a Visit, 76.

$104 \quad$ Eastwick, Dry Leaves from Young Egypt, 203.

105 Naomal Hotchand, A Forgotten Chapter of India History as Described in the Memoir of Seth Naomal Hotchand C.S.I of Karachi 1804-1878, tr. Rao Bahadur Alumal Trikamdas Bhojwani, ed. with an introduction from Sir H. Evan M. James with a New Introduction by Hamida Khuro, (Karachi: OUP, 1982).
} 
disenchanted with the Talpurs whose policies they judged to discriminate against local traders. Particularly resented were the high tariff charges imposed in every small administrative unit that had resulted from the Talpurs' fragmentation of larger units.

Did the Talpurs discriminate against the Hindu merchants on religious grounds? The available evidence does not show this to be the case. Hinduism in Sindh, because it was closely associated with and influenced by Sufism, was a 'Hinduism with Sindh characteristics'; it was eclectic and local in character. ${ }^{106}$ Brahmanical Hinduism was, therefore, absent in Sind. The Brahmans here, divided into the two sub-castes of Saraswat and the Pushana, were numerically a minority not socially prominent. Small non-Brahman Hindu communities included the Khatris, Banias, Bhatias and several tribes that had not been absorbed into Hinduism's caste system. The tribalism that characterised much of Sindh society and the presence of only one sizeable Hindu community, the Lohanas, meant that the caste system that was embedded in Hinduism in most other parts of the Indian subcontinent did not develop in Sindh. ${ }^{107}$ There were three occupational groups within the Lohanas: the Amils had positions as government officials in the revenue department or worked as scribes; the bhaibands were merchants; and the Sahitis were either merchants or in salaried employment. ${ }^{108}$

Most members of Sindh's Hindu communities visited popular Sufi dargas and did not belong to a Hindu-defined caste. Hinduism in Sindh, therefore, can be described as eclectic, accultural and even liminal. The Sufis of Sindh acted as lynchpins between a range of ethnic, sectarian and religious communities, and had followings within Hindu communities. This give the lie to claims that Hindu-Muslim communal tension and the Talpurs' discrimination against the Hindus on religious grounds justified Britain's annexation of Sindh in 1843, Charles Napier's assertions notwithstanding. It is true that the Talpurs presided over a tribal confederacy, and

Markovits, The Global World of Indian Merchants, 49-50.

Ibid., 47.

Mark Anthony Falzon, Cosmopolitan Connections: The Sindhi Diaspora, 1860-2000, (Netherlands: Koninklijke Brill NV), 33-34. 
they favoured their kinsmen in matters related to state affairs. Even so, they did not restrict powerful positions to members of their own tribe. They appointed, for example, some Hindu Lohana Amils to administrative posts. This was continuation of a Mughal practice; for example, in the sixteenth century the Mughals had appointed Todar Mal, a Hindu Khatri, to the position of state treasurer. ${ }^{109}$

Also, under the Talpurs, the revenue collection department was staffed by Hindu Amils. These people, therefore wielded considerable political power in Sindh. This was not recognised by British travellers such as James Burns who claimed that the Talpurs oppressed the Hindus. ${ }^{110}$ Nor was it recognised by Charles Napier who claimed that because Sindh's Hindus were oppressed by the Talpurs, Sindh needed to be annexed by Britain.

\section{Conclusion}

This chapter has narrated the story of the gradual rise of the Talpurs in Sindhi politics and the gradual decline of Sindh under their tutelege. While the later Kalhora rule became weakened by repeated succession struggles and court politics, the Talpur chiefs, former murids of the Kalhoras, began to assert their power and ultimately took over the rule from their former masters. But continued pressure from Afghanistan for tribute, disputes within the Talpur ruling family and decline of the economy led to Sindh's progressive decline. Although the Talpurs tried to rule Sindh as a tribal confederacy, there was more continuity between the administrative systems of the Kalhora and the Talpurs. Because of a developing economic crisis, the Talpurs began to put pressure on the traders, mainly Hindus, but also Europeans like the EIC. And this led to their undoing.

British policy in relation to Sindh developed in phases, and was shaped by changes in international alignments and conflicts. The next chapters will evaluate whether the 'sub-imperialism' of 'men on the spot', that is, strategies employed by

Stephen Fredrick Dale, Indian Merchants and the Eurasian Trade, 1600- 1750, (Cambridge: Cambridge University Press, 1994), 33. Burnes, A Visit to the Court of Sinde, 76. 
Governor-General Ellenborough and Major-General Charles Napier, were solely responsible for the annexation of Sindh in 1843; that they were is an argument made by many historians, including Robert Huttenback. ${ }^{111}$ And what of the role played by the different Meers who ruled Sindh in the early nineteenth century? To what extent did the stands they took in relation to Britain and to neighbouring states contribute to the demise of Talpur rule in Sindh? The policies of Sindh's rulers in the decades before annexation will also be examined in the next chapter.

J.F. Heddle asserted in 1836 that the Talpur Meers followed an 'isolationist policy' in relation to neighbouring states. ${ }^{112}$ This is an odd claim to make given that, in the first twenty years of Talpur rule, Sindh's state boundaries were significantly extended: Karachi was taken from the Khans of Kelat; Shikarpur was retrieved from the Afghans; and Umerkot was recovered from the Raja of Jodhpur. ${ }^{113}$ Also absorbed into Sindh were some places in the state of Bahawalpur, ruled by the Daudputras; the town of Sabzal Kot, for example, was incorporated into Sindh by the Talpur Meers in 1807. The Meers had an amicable relationship with the rulers of Persia, who wielded considerable influence over court culture in Sindh; many Talpur Meers, as a result of Persian influence, were followers of Shia Islam. The Meers also tried to seek British help against the growing threat of an attack from the Punjab under Ranjit Singh. The revival of the Meers' relations with the British two decades or so after the closure of the Company's factory in Sindh in 1775 was due to the British perceptions of a French threat, a threat that particularly worried Lord Richard Welleseley, the British Governor- General of Bengal from1798 to 1805. The next chapter will explore how the dynamics among the European, Central Asian and north-west Indian powers shaped each other's policies.

\footnotetext{
111 Robert Huttenback, British Relations with Sindh, 1799-1843, (Berkeley and Los Angeles: University of California Press, 1962), 113-120.

112 J.F. Heddle, 'Memoir on the River Indus, May, 1836 in Selections from the Records of the Bombay Government, no. XVII, Vol. ii.

113 Burnes, A Visit to the Court of Sinde, xix, xx.
} 


\section{Chapter 4}

\section{Regional Politics and British Intervention}

The East India Company established a factory at Thatta in Sindh in 1636 but closed it in 1662. The factory was reopened in 1758, closed in 1775, and reopened again briefly from 1799 to 1801 . As explained in the last chapter, the Company had to close down the Thatta factory in 1775 because it was incurring losses, a consequence of the policies of the then ruler Sarfaraz Khan Kalhora. After a lapse of 24 years the Company re-opened the factory in 1799, due to the initiative of Lord Richard Wellesley, the Governor-General (1798-1805). Wellesley worked at changing the nature of the Company from a corporate organisation based on the policy of free trade to a sovereign political authority in India. In the later years of the eighteenth century he realised that British power had become internally vulnerable in its newly established dominions in India, as many local princes and states were hostile to it, including the Nizam of Hyderabad, the state of Mysore (which had allied with France), the Maratha Confederacy and the Kingdom of Awadh. ${ }^{1}$

Wellesley embarked on a policy of conquest and strict administrative control of the Company's Indian possessions, without much support from London. Gerard Lake, commander in chief of the Indian army, was a loyal supporter of Wellesley and this helped Wellesley bring the Indian army under his control. Wellesley's position in the Court of Directors in London was also strengthened by the appointment of his own supporters to various political posts. ${ }^{2}$ On 18 March 1799, Henry Dundas, a member of the Cabinet in London, wrote to Wellesley that the Company needed to secure its investments in India. ${ }^{3}$ Dundas believed that after the loss of America, it was India that could be a source of wealth for Great Britain. He

\footnotetext{
Amandeep Singh Madra and Parmjit Singh, 'Ranjit Singh's Correspondence with the British, 1803 ' in Amandeep Singh Madra and Parmjit Singh ed., "Sicques, tigers, or Thieves": Eyewitness Accounts of the Sikhs (1606-1809) (New York : Palgrave Macmillan, 2004), 115. C. A. Bayly, Indian Society and the Making of the British Empire (Cambridge: Cambridge University Press, 1990), 82-83.

The Right Hon. Henry Dundas to the Earl of Mornington, 18 March 1799, no. xxvii, Arthur Wellesley of Wellington, The Despatches, Minutes, and Correspondence, of the Marquess Wellesley, K. G. During His Administration in India (London: Murry, 1836), 101-103.
} 
drew the attention of members of the British Cabinet to possible ambitions of the French in India. But his concerns about a possible invasion of India by France did not find much support in Cabinet. ${ }^{4}$

The need to deal with France was taken seriously, however, by Lord Wellesley; he used it as a pretext for creating the Anglo-Indian Empire that he was aiming for. Robert A. Huttenback argues that it was to protect India from a possible French attack that Wellesley sent a mission to Sindh in $1799 .{ }^{5}$ We will show, however, that the French threat was not an actual reason but rather a pretext used by Wellesley to convince the Board of Directors and the British Government to establish contacts with Sindh. Wellesley also used the French excuse to start the fourth Anglo-Mysore war. There is little historical evidence to suggest that a French menace was real so far as India was concerned. After the French defeat at the Battle of the Nile in August 1798 it disappeared completely. On the other hand, the affairs in the Middle East in general, including political developments in Afghanistan and Persia in particular, and the designs of Russia and France in general, were sources of concern for the British and possibly were the real reasons why Sindh figured so prominently in British imperial strategy in the late eighteenth and early nineteenth centuries.

Soon after his arrival in India in April 1798, Wellesley had obtained intelligence from Mauritius about a proclamation of the French Governor, General Mons. Malartic. It disclosed the proposal of Tipu Sultan, the ruler of Mysore, to mount an offensive - defensive alliance against the British. ${ }^{6}$ Mons. Malartic agreed to ally with Tipu and despatched volunteers to Seringapatam. ${ }^{7}$ Earlier, in 1787, Tipu's connection with France's Louis XVI was also, as Kate Brittlebank points out,

4 Edward Ingram, In Defence of British India: Great Britain in the Middle East, 1775-1842 (London: Frank Cass, 1984), 36.

Robert A. Huttenback, British Relations with Sindh 1799-1843: An Anatomy of Imperialism (Berkeley and Los Angeles: University of California Press, 1962), 2.

$6 \quad$ Arthur Wellesley (1st duke of Wellington.), The Dispatches of ... the Duke of Wellington, Compiled by Lieut. Colonel Gurwood. Suppl. to Vol. 1/3 Index. Index (London: John Murray, 1837), 7.

$7 \quad$ Iradj Amini, Napoleon and Persia: Franco-Persian Relations Under the First Empire (Washington D.C.: Mage Publication, 1999), 32. 
revealed in correspondence in which Tipu asked the French King to send French gunsmiths and other artisans such as weavers, glass makers, farmers and engineers. ${ }^{8}$ Tipu also contacted Shah Zaman of Afghanistan and several other native princes of India such as the rulers of Hyderabad and of the Maratha confederacy to propose alliances against the British. ${ }^{9}$ There was also a widespread belief at that time that Shah Zaman had links with the Rohilla Afghans of India and that he had also been approached by the ousted Nawab of Awadh, Wazir Ali, to help him regain the throne of Awadh by invading India and ousting the British from Bengal, Bihar and Orissa. ${ }^{10}$

In 1798, the British were primarily concerned about two things. First, they wanted to aid the British admiral in preventing France from pursuing its imperial plans in the Red Sea. Second, Shah Zaman, the ruler of Afghanistan, was to be stopped from undertaking another possible incursion into India. ${ }^{11}$ To protect the north-west frontier from an invasion by Shah Zaman, Wellesley argued that the Wazir's army in Awadh be disbanded and replaced with the Company's subsidiary force. Dundas too supported Wellesley's policy of a subsidiary alliance, because not only was he alarmed by Shah Zaman's alliance with France and their possible invasion of India, he was also anxious about the Company's rising expenses; financial outlay could be reduced by the maintenance of the Company's subsidiary army in Awadh at the Wazir's expense. By 1799 Dundas, like Wellesley, was keen to expand British territories in India, but his stance on expansion changed when military defeats made him worried about the Company's finances. This brought the difference between Wellesley and Dundas regarding Britain's imperial policy in India to the surface. Dundas wanted to reduce the Company's debt and to use surplus revenue from India for commercial rather than political purposes. He wanted to curb

8 Kate Brittlebank, Tipu Sultan's Search for Legitimacy, Islam and Kingship in a Hindu Domain (Delhi: Oxford University Press, 1997), 103.

9 Wellington, The Dispatches of ... the Duke of Wellington, 8.

10 Rudranghshu Mukherjee, 'Trade and Empire in Awadh: 1776-1804', Past and Present, 1982, no.94., 88 .

11 Letter from the Earl of Mornington to the Hon. Jonathan Duncan, Fort William, $24^{\text {th }}$ October 1798 in The Despatches, Minutes, and Correspondence of the Marquess Wellesley K.G. During His Administration in India Vol. I, ed. Montgomery Martin (London: Wm. H. Allen, 1837), 308. 
the military expenses of the Company. But Wellesley continued warring with the Indian states, leaving the Company without funds to pay even for its army. ${ }^{12}$

Whether it was because of French imperial ambitions that the British developed strategies for defending British India, or that these strategies were for expanding the empire and also engaging in Middle Eastern affairs, is a question that is much debated by historians. From the discussions among the British officials at the time there developed a strategy to be followed in the Middle East and Asia that, in 1841, British officer Arthur Conolly dubbed 'the Great Game'; ${ }^{13}$ Conolly was a lieutenant in the Bengal native cavalry. ${ }^{14}$ Although he used the term to define the British policies designed to contain Russia from 1828 onwards, ${ }^{15}$ the 'Great Game' strategies were developed during Briain's conflict with France during the Napoleonic Wars, beginning from 1798 when Napoleon invaded Egypt. During the War of the Second Coalition (1798-1802), Napoleon had declared his plan of invading India after his campaign against Egypt. On 8 September 1798, he wrote to the French Directory: 'France will sooner or later become the ruler of India.' ${ }^{16}$ Tipu's attitude towards France encouraged Napoleon to consider invasion of India as a continuation of his plan of conquest in the Near East.

Unless France retreated to its Atlantic ports, the superiority of British Sea power would not be enough to ensure British security in the Indian Ocean. Napoleon's successful campaigns against Egypt in 1798 led to talks in London about the possibility of a French invasion of India through Persia. Wellesley argued that there was a chance that Mysore could receive support from France. Because of this danger, Britain invaded Mysore on 11 February 1799; the fighting ended on 4 April,

Edward Ingram, ed., Two Views of British India: Private Correspondence of Mr.Dundas and Lord Wellesley, 1798-1801 (Bath: Adams \& Dart, 1970),9.

13 The British, to defend India needed to find an ally in the Middle East which sparked controversy among the British officials Wellesely and Harford Jones, the British Resident at Basra in Afghanistan, regarding who this prospective ally could be. Ingram, In Defence of British India, 2-3.

14 Peter Hopkirk, The Great Game: On Secret Service in High Asia (Oxford: Oxford University Press, 2001).

15 The Great Game in Asia to resist Russian expansion developed mainly after the failure of the treaty of Turkmanchy with Persia in 1828. Ingram, In Defence of British India, 153.

16 Iradj Amini, Napoleon and Persia: Franco-Persian Relations under the First Empire (Washington, D.C.: Mage Publishers, 1999), 32. 
when the fort of Seringapatam was seized and Tipu Sultan killed. ${ }^{17}$ The concern of the English was now to secure their Persian Gulf trade and their possessions in India against a French attack. ${ }^{18}$

Napoleon, however, was defeated by the British fleet under Nelson in the Battle of the Nile at Aboukir Bay in August 1799. ${ }^{19}$ Dundas wrote to Wellesley: 'I flatter myself Lord Nelson's splendid victory, and the exertion of our fleet in the Mediterranean, leave us little reason to apprehend any danger at present to India from the French force which has landed in Egypt. ${ }^{, 20}$ Nevertheless, Wellesley used the spectre of a possible comeback by Napoleon to validate his drive to create an Anglo-Indian Empire. ${ }^{21}$ Also, the British at this time were not only concerned about French expansion. British interests were also threatened by Afghanistan, Persian and Russian imperialism in the Middle East.

The factors that shaped Wellesley's policies towards Hyderabad, Mysore, Awadh, Sindh and the Deccan were different. In Awadh the nature of British trade was a major factor behind the Company's political advance into the region in 1801. The Company reaped huge profits from the indigo it purchased in Awadh. ${ }^{22}$ Wellesley's policies resulted in the cession of half of Awadh to the Company. Hyderabad, which became a subsidiary ally of the British, was annexed after the mutiny of 1857 because of the British policy of paramountcy. Sekhar Bandyopadhyay argues that in Deccan it was the concern to secure the British cotton trade in Western India from the Marathas which led to the series of Anglo-Maratha wars and the Marathas' defeat in $1818 .{ }^{23}$ Sindh, however, had no connection with the Company after the EIC factory there was closed in 1775 . Shah Zaman, to re-

\footnotetext{
$17 \quad$ Amini, Napoleon and Persia, 36.

18 Ibid., 31.

19 Bowen, H. V. The Business of Empire: The East India Company and Imperial Britain, 17561833 (Cambridge: Cambridge University Press, 2008), 44. The Rt Hon. Henry Dundas to the Earl of Mornington, 18 March 1799. Wimbledon, Private: no.6 in Ingram ed. Two Views of British India, 128. Ibid., 129-130. Rudranghshu Mukherjee, 'Early British Imperialism in India: A Rejoinder', Past and Present, no. 106 , Feb., 1985, 170.

3 Sekhar Bandyopadhyay: From Plassey to Partition: a History of Modern India (New Delhi: Orient Blackswan Private Ltd., 2008), 53-54.
} 
establish the Afghan influence in Lahore, marched against the Marathas in 1796. The manoeuvrings of the Afghans and the French in the regions close to the western boundary of British India raised the issue of its security. ${ }^{24}$

To protect its boundary against Shah Zaman's depredations, Lord Wellesley evolved a policy of checking the Afghan moves along two fronts - one in Persia and the other in Sindh. ${ }^{25}$ While the War of the Second Coalition was in progress, Harford Jones, the British Resident at Baghdad (1798-1806), suggested an Anglo-Afghan alliance rather than an Anglo- Persian one, because of the insecurity of Kajar rule in Persia. Wellesley decided to persuade the British government to opt for an alliance with Persia as a way of keeping Afghanistan weak. Wellesley also wrote to Jonathan Duncan, the then Governor of Bombay (1795-1811): the 'Talpur Meers of Sindh have grown sick of Afghan overlordship. It would be worthwhile to establish a business factory in Sindh to keep an eye on the activities of Afghanistan, Iran, Russia and France in the region. ${ }^{26}$

In December 1798 Duncan dispatched three letters and a selection of gifts to the Talpur Meers in Hyderabad Sindh through Agha Abdul Hasan, a Persian merchant from Bushir in the Persian Gulf. The letters expressed the desire of the Company to re-establish the commercial links it had with Sindh in the past. Abdul Hassan was told in confidence that Britain would give military assistance to the Talpur Meers should they engage in a war with Shah Zaman. When in Hyderabad, however, he was not to disclose Britain's interest in a confrontation with Afghanistan, nor its willingness to give military support to Sindh in the event of a Sindh-Afghanistan war. Instead he was to persuade the Meers of the benefits that would accrue from a commercial relationship with Britain. ${ }^{27}$

\footnotetext{
$24 \quad$ Ibid., 170.

25 Parveen Talpur, Talpur Rule in Sindh (Lahore: Ferozsons (Pvt) Limited, 2002), 39.

26 Ghulam Muhammad Lakho, 'Sindh- Iran Relations during the Talpur Period', Journal of Pakistan Historical Society, Vol. LVI, no. 1, 2008, 62.

27 Government of Bombay to Aga Hasan, 26 December 1798 (despatch from Bombay Castle, 23 April 1799), Secret and Political Department, Diary no. 77, Maharashtra State Archives [hereafter MSA].
} 
Aga Abul Hasan acted as Duncan instructed. When he met with the Meers on 2 March 1799, he worked at persuading them to allow the Company again to establish factories in Sindh and on the same terms as applied during the days of Ghulam Shah Kalhora. Meer Fateh Ali agreed to what the British proposed, but not only for the commercial benefits to be gained. At that time a member of the ousted Kalhora dynasty was allegedly conspiring to seize back control of Sindh with the help of Shah Zaman. Because Meer Fateh Ali sought to free Sindh from Afghan influence and prevent the Kalhoras from regaining power, he agreed to ally with the British. ${ }^{28}$ Thus, as occurred in many other regions of India, the internal rivalry between the Sindhi noble families paved the way for the Company to regain a foothold in Sindh.

By the end of March 1799, Meer Fateh Ali Khan had issued three parwanas to the Company which gave it the licence to establish a factory in Thatta, granted four acres of tax free land for a garden and fixed the rates of custom duties on the goods that the Company was to trade; these provisions were the same as those fixed back in 1758. Aga Khan forwarded the three parwanas to Duncan in Bombay, who then selected Nathan Crow from the Bombay Civil Service to develop the British mission in Sindh. ${ }^{29}$ Wellesley instructed to the Resident of Bushire in Persia, who had been there since 1763, to check Afghans and French in Persia.. ${ }^{30} \mathrm{He}$ also sent Mirza Mehed Ali Khan, his agent, to the court of Fateh Ali Shah (Baba Khan) of Persia for checking France. ${ }^{31}$

The Board's instruction to Crow about his conduct in Sindh makes clear the Company's motive in making fresh overtures to Sindh's rulers - that is, to keep a close eye on any moves made by Shah Zaman and the French in relation to India.

\footnotetext{
$28 \quad$ Talpur, Talpur Rule in Sindh, 40.

29 Board of Directors to Nathan Crow, $8^{\text {th }}$ May 1799, Bombay Castle, despatch dated $10^{\text {th }}$ May 1799, Secret and Political Department, no. 78, 3511-3518, MSA.

30 Ibid., 3514-3518, C.U. Aitchison, A Collection of Treaties, Engagements and Sunnuds, Relating to India and Neighbouring Countries, Containing the Treaties Relating to Sindh, Ballochistan, Persia and Herat;Turkish Arabia and Persian Gulf, and the Arabian and African Coast, V. II, (Calcutta: O.T. Cutter, 1862), 102.

31 Board of Directors to Nathan Crow, $8^{\text {th }}$ May 1799, Bombay Castle, despatch dated $10^{\text {th }}$ May 1799, Secret and Political Department, no. 78, MSA.
} 
The surveillance was to be done under cover of a growing commercial alliance with Sindh's rulers. Crow was briefed about the Company's first factory in $\operatorname{Sindh}^{32}$ and he arrived there on 26 May 1799 with a cargo of goods to sell. Unexpectedly, however, he had to face hostility from the Talpur Meers and the local merchants. ${ }^{33}$

The Meers were now hostile to the British agent because the Afghan threat had receded in the meanwhile and there was opposition to the British presence among the mercantile class. As noted earlier, however, the mercantile opinion about the Company later changed and, by the 1830s, the Sindhi merchants had become one of the strongest supporters of the British intervention in Sindh. ${ }^{34}$

Trouble caused by Shah Zaman's half-brother made the Afghan ruler decide to retreat to Kabul, and that convinced the Meers that they need no longer worry about the Afghan overlord. ${ }^{35}$ As for the Karachi merchants, a group of them complained to the Meers that the arrival of Nathan Crow was against their interest; Company trade would damage their trade. ${ }^{36}$ In the 1790 s, Britain had not yet emerged as a powerful player in Sindh politics, and so local traders regarded the British merchant as just another competitor in the market. Crow was not received by any agent of the Meers at Karachi. He wrote to the Meers requesting permission to proceed to Thatta, but was left waiting in Karachi for a month before permission was given. While in Karachi, local merchants tried to obstruct any attempt he made to sell goods that he had in his cargo, including English cloth. ${ }^{37}$ Nathan Crow left Karachi on 16 June 1799 and arrived in Thatta eight days later. He found that the Thatta merchants and inhabitants were also hostile. After inspecting the town's old EIC factory, he left for Hyderabad to meet with the Meers. ${ }^{38}$ Crow's report on the

33 Letter from the Resident, $30^{\text {th }}$ September 1799, Despatched from Bombay Castle, $22^{\text {nd }}$ October 1799, Secret and Political Department, no. 84, 6133-6135, MSA. See Chapter 3, 107

35 S. R. Bakshi and Rashmi Pathak, Punjab through the Ages (New Delhi: Sarup \& Sons, 2001), 4.

36 Letter from the Resident, 30th September 1799, Despatched from Bombay Castle, 22nd October 1799, Secret and Political Department, no. 84, 6135-6138, MSA.

37 Letter from the Resident, $30^{\text {th }}$ September 1799, Despatched from Bombay Castle, $22^{\text {nd }}$ October 1799, Secret and Political Department, no. 84, 6138, MSA. Ibid, 6137-6139. 
court ceremonies and culture of the Meers at Hyderabad provides insights into the nature of state over which they ruled. Crow found the Talpur court as grand and splendid as any Indian court in the eighteenth century. The Meers overawed visitors with displays of pomp and ceremony designed as demonstration of their power. ${ }^{39}$

As noted in Chapter 3, the first generation of Talpur rulers shared power and ruled jointly in Hyderabad without any major differences of opinion among them. Four Meers presided over the same court and were called 'chaho yar', or four friends. Crow noted that they were always alert to any conspiracy against them among other tribal chiefs or family members of the deposed Kalhora rulers. He wrote:

[I]n Durbar (Court) the Prince and his brothers sit each with his sabre girt and his shields slung and a relief of saddled steeds is always kept up for any emergency. The four brothers in general eat together, and instead of retiring at night to different apartments, invariably sleep in the same room with arms by their side, and without any lights but at the doorway. ${ }^{40}$

Crow also claimed that the Meers were only interested in amassing wealth for themselves without caring about their subjects. ${ }^{41}$ This however is not reflected in the will left by Meer Fateh Ali when he died in 1801; the will nominated Meer Ghulam Ali as his successor and instructed him to consider serving his subjects as his primary duty. When Meer Fateh Ali ruled Sindh, however, he took more care of fellow members of the Baluch tribe, describing them as 'the backbone of the country' who were always to be kept 'happy'. ${ }^{42}$ It might be that Crow had observed the preferential treatment that Meer Fateh Ali gave to Baluch tribesmen to the detriment of his non-Baluch subjects.

$39 \quad$ Ibid, 6143.

40 Nathan Crow, Account of the Country of Sind.MS. 1081. Institute of Sindhology in Mubarak Ali ed. Social and Cultural History of Sindh: Based on Accounts of the European Travellers Who Visited Sindh (Lahore: Fiction House, 2005), 225.

41 Ibid., 225.

42 Maulana Noor Muhammad Khan Faridi, Sindh ke Talpur Hukumran (Multan: Siraiki Adabi Tahrikh, 1982), 72. 
Although the first set of four Talpur rulers ruled their tribal confederacy in tandem, internecine tribal conflicts broke out among the surviving three after the death of Meer Fateh Ali, a development that will be discussed later in this chapter. Crow noted that the Talpur state was an Islamic theocracy. ${ }^{43}$ Every action at the court was rendered with a chant of 'bismillah' (in the name of God). ${ }^{44}$ Crow was asked to observe a certain etiquette while meeting with the Meers at court; for example, he was to get off his horse at the front gate of the court, take his shoes off at the door, remove his hat in front of the ruler, place a gold coin on a handkerchief at his feet and sit cross-legged on the floor. Crow agreed to meet all of these requirements except the placing of a gold coin at the ruler's feet, because he found it too humiliating. The ruler agreed to exempt him from this requirement. ${ }^{45}$

At a private meeting with Meer Fateh Ali on 23 July 1799, Crow asked that the ruler issue a parwana consolidating all the privileges granted to the Company by Ghulam Shah Kalhora. He also requested that he grant similar privileges to a factory in Karachi, a request that the Meer rejected. The mercantile community of Sindh was against the establishment of a Company factory at Karachi and lobbied against it. ${ }^{46}$ The Meer, therefore, agreed to grant Thatta factory to the Company. ${ }^{47}$ Crow also had a meeting with Ghulam Ali Khan, one of the other Meers, on 25 July. Ghulam Ali

H.T. Sorely, Shah Abdul Latif of Bhit: His Poetry, Life and Times: A Study of Literary, Social and Economic Conditions in the Eighteenth Century Sind, Revised ed. (London: Oxford University Press, 1966), 10.

4 Letter from the Resident, $30^{\text {th }}$ September 1799, Despatched from Bombay Castle, $22^{\text {nd }}$ October 1799, Secret and Political Department, no. 84, 6143, MSA. Ibid., 6141-6142. Ibid., 6148-6150. The Company's demand that special privileges be granted to the British Factory in Karachi went against the interest of local merchants. If the Meers exempted the Company from paying customs duties local merchants could incur a serious loss of revenue. Nevertheless, there is evidence in the 1830s of some corporate families and merchants in Sindh supporting the British against the Meers. This alliance between the British and indigenous merchants has been discussed by Lakshmi Subramanian. See 'Banias and the British: The Role of Indigenous Credit in the Process of Imperial Expansion in Western India in the Second Half of the Eighteenth Century', Modern Asian Studies, Vol. 21, no. 3, 473510. From the Resident, 30 September 1799, Secret and Political Department, no. 84, 6148-6150. MSA. 
agreed to cooperate with Crow and asked him to arrange for a gunner and a surgeon to be sent from Bombay. ${ }^{48}$

Ultimately, Crow received a parwana from Fateh Ali dated 18 August 1799 that granted permission to open a factory at Karachi and sanctioned other privileges such as tax-free land for a garden; these privileges had been promised to Aga Abul Hasan, the Company's Persian agent. It also instructed the collector of duties on trade to exact from the Company only one-third of the normal custom duty so that EIC trade could develop. Sindh's rulers expected that, as a result of increased trade volume, government revenue would increase as well. Another parwana dated 22 August 1799 granted the Company the right to open a factory in Thatta with all the old privileges it had in 1761, except the monopoly of the saltpetre export trade. ${ }^{49}$ Most importantly, the parwana also declared that no other European trader was allowed to pass through or trade in Sindh; those rights were exclusive to agents of the English Company. ${ }^{50}$

The Company re-opened its factory at Thatta on 8 September 1799 and established a new factory at Karachi on 29 September. Crow advised Duncan that a Residency in Hyderabad would be commercially and politically beneficial to the Company. The principal commercial aim of the factory was the sale of British woollen cloth. It was estimated that the Company could import to Karachi goods such as Chinese sugar, Malabar pepper and other British staples worth about two or three hundred thousand rupees annually. The total annual sale of British goods at both Thatta and Karachi was estimated to be worth four hundred thousand rupees. Crow also reported his observations on the geography of Sindh, local terrains and the threats to Sindh posed by Shah Zaman's manoueverings. There were rumours in the late 1790s that Shah Zaman wanted to send four thousand families from Afghanistan to Sindh; the Meers were unsettled by the rumours. ${ }^{51}$

\footnotetext{
$48 \quad$ Ibid., 6150-6152.

$49 \quad$ Aitchison, A Collection of treaties, 29.

50 Ibid., 18 .

51 Letter from the Resident, Secret and Political Department, 12 November 1799,no. 85, 6516, MSA.
} 
At this point Meer Ghulam Ali requested that Crow arrange for artillery and artillerymen to be sent to Hyderabad. Duncan's response was to send artillerymen John Hamilton and James Wallet from Bombay and to supply the Meer with 400 artillery shells; he instructed Crow to make sure that the men and equipment were not used by the Meer against any of Sindh's neighbouring states. ${ }^{52}$ The Meer's request for military aid might be an indication of the Talpurs' military weakness. It certainly indicates the Meer's concern to have a stronger armed force. Ghulam Ali was perhaps anticipating the need to resist an Afghan military incursion into Sindh that aimed either to collect tribute from the Talpurs or to expand the Afghan empire. Another possibility is that the Meers were preparing for an attempt by a member of the deposed Kalhora family to regain the Sindh throne. Abdul Nabi Kalhora had appealed to Jodhpur and then to Bahawalpur, the Punjab, Afghanistan and the Company for help against the Talpurs. All the powers to which he appealed, however, turned him down. ${ }^{53}$

Despite the military aid, the Meers, for many reasons, remained suspicious of British intentions in Sindh. In early1800 Crow wanted to make contact with an agent from Afghanistan, Ulkatah Khan, who had come to Hyderabad to collect tribute for Shah Zaman and to purchase cloth worth Rs. 40,000. But Crow chose not to make the contact directly because he knew that it would arouse the Meers' suspicions. ${ }^{54}$ Around this time the Company's trading relations with Sindh had attracted attention in Qandahar, and Crow suggested that the Company send an agent to that place as well. ${ }^{55}$ Meer Ghulam Ali, already suspicious of the British, asked Crow about the Company's mission in both Persia and the state of Cutch. Crow's answer, that the mission to Tehran was to establish friendship with Persia, did not convince Ghulam Ali. The Meers were also interested in annexing Cutch because, located on the south side of the Indus, it had abundant fertile agricultural land; this is a reason why December 1799, no. 85, 6787, MSA.

53 Parveen Talpur, Talpur Rule in Sindh, 20-21.

54 Letter from the Resident, $17^{\text {th }}$ May 1800, Secret and Political Department, no. $102,28^{\text {th }}$ November 1800, 7086-7087, MSA.

55 Crow to Jonathan Duncan, Governor of Bombay, Secret and Political Department, 29 October 1800, no. 102 (15), 7093, MSA.
} 
Ghulam Shah Kalhora seized and, for a time, held the Cutch state capital back in the 1760s. ${ }^{56}$ It was not surprising that Cutch became, in Robert A. Huttenback's words, an issue of 'controversy' between the Meers and the Company; this is a subject to which we will return in the next chapter. ${ }^{57}$

As a result of the lingering suspicions, and conflicting ambitions, the Company was soon to suffer a setback in Sindh. Wellesley once wrote to Dundas that the information Crow provided about Shah Zaman was 'more accurate' than that any he had ever received during his time in India. ${ }^{58}$ In other words, the judgments of the Company's agent in Sindh were respected in Bombay. Crow noted that if the Company needed to take an offensive stance against Afghanistan in the future, the Sindhis could not be involved because the Meers did not have the 'power of having hostility nor even provoking them [the Afghanis]'. The Meers should be asked to do no more than ensure the Company had a safe passage through Sindh to Afghanistan. ${ }^{59}$ But even the hopes for that level of assistance were soon dashed. Crow was right in his assessment of the Meers' powerlessness in the face of any pressure from Afghanistan. Sindh's rulers responded promptly when Shah Zaman ordered that they make the English leave Sindh, for they could not afford to offend the Afghan ruler. On 12 August 1800, Meer Fath Ali issued a parwana asking Crow to close down the Company's Karachi factory. ${ }^{60}$ It was not Meer Fateh Ali who wanted to issue the parwana; it was mainly Ghulam Ali's initiative, supported by the other two Meers. ${ }^{61}$

One reason behind this decision was the Meers' lingering doubts about the strength of the Company and, therefore, whether it was a dependable alternative source of support against Afghanistan. In a private meeting with Crow, Meer See Chapter 2 of the thesis and Ghulam Muhammad Lakho, Kalhora Daure Hukumat (Karachi: Anjuman Athad-i Abbasia Pakistan, 2004), 265.

57 Robert A. Huttenback, British Relations with Sindh, 13-18.

58 From Earl of Mornington to the Rt Hon. Henry Dundas, 29 November 1799, Fort William, Private: no. 20 in Ingram ed. Two Views of British India, 212.

$59 \quad$ Letter from Crow to Jonathan Duncan, President and Governor at Bombay, Secret and Political Department, 12 August 1800, no. 102, 7252-7254, MSA.

60 Ibid., 7156-7158, MSA.

61 Crow to Duncan, $29^{\text {th }}$ October, Secret and Political Department, Diary no. 102 of 1800, 7209, MSA.
} 
Ghulam Ali asked about the competence of the Company's artillerymen: 'Is it with such fellows as these that you take countries?' The English control of the district of Surat also made the Meer suspicious about the real intentions of the Company. In mid-1800, a Marathas' agent from Nagpur visited the Hyderabad court and further prejudiced the Meers against the Company. ${ }^{62}$ Soon, on 29 October 1800, the Meers ordered Crow to shut the Company factory in Thatta as well, and to leave Sindh within five days. ${ }^{63}$ The Company had no choice but to follow the Meers' orders because it was not yet the supreme power in India. The Marathas were still a force to be reckoned with, and were not subdued until the Anglo-Maratha war of 1803$1805 .^{64}$

The security of the Company's Indian possessions were significantly threatened by Shah Zaman. So it was imprudent at this time for the Company to throw its weight around in any of the regions beyond the western borders of the British empire. To remove the French from the region, the Company allied with the Imam of Muscat on 12 October 1798 and with the king of Persia in January $1801 .^{65}$ Unable to secure Sindh's cooperation in the campaign to stop Afghan moves into British India, Wellesley succeeded in winning Persia's help instead. In January 1801, John Malcolm, the representative sent by Wellesley to Persia, obtained a memorandum from Fateh Ali, the King of Persia, stating that Persia and England agreed to cooperate with each other to resist any move by France or Afghanistan against the territories of either Persia or British India. ${ }^{66}$ The English wanted the alliance with the Persians to drive back France, but Persia was also looking for support against Russia which, after annexing Georgia in 1802, had come close to Persia's borders.

62 Crow to Duncan, $26^{\text {th }}$ August 1800, Secret and Political Department, $28^{\text {th }}$ November 1800 , no. 102 7138, MSA.

63 Ibid., 7223.

64 John Pemble, 'Resources and Techniques in the Second Maratha War', The Historical Journal, Vol. 19, Jan 1976, no. 2, 375-404.

65 C. U. Aitchison, A Collection of Treaties, Engagements, and Sunnuds relating to India and Neighbouring Countries, vol. VII, (Calcutta: Re-printed at the Foreign Office Press, 1876), 104, 201.

66 Aitchison, A Collection of Treaties, Engagements and Sunnuds, 106. 
At the beginning of the nineteenth century, certain developments in the region north-west of Sindh resulted in another change in the Meers' attitude towards the English, and they themselves now approached the Company to propose an alliance. In 1803 Shah Shuja, who became the ruler of Afghanistan after deposing Muhammad Shah, marched towards Sindh to collect tribute. Meer Ghulam Ali chose not to resist and advanced him a sum of Rs. 500,000, with a promise to pay an additional Rs. 500,0000 later. ${ }^{67}$ Shah Shuja returned to Afghanistan, but Meer Ghulam Ali, instead of paying him the promised additional amount, started to seek potential allies against Afghanistan. He wrote to Jonathan Duncan to propose an alliance between the Company and Sindh. The Meer informed Duncan that France wanted to get a foothold in Sindh. ${ }^{68}$ The Company had approached the ruler of Jodhpur to propose an alliance. But Ghulam Ali wanted the Company to help him annex Umarkot, a desert area lying east of Sindh. Now part of the state of Jodhpur, it had belonged to the Kalhoran kingdom from 1750 to $1783 .{ }^{69}$ Our sources do not mention why the Talpurs wanted to take Umarkot. It was probably judged to be important for its strategic location on the road connecting Marwar to the Indus valley; the caravan trade between these two regions used this highroad. Also, Ghulam Ali wanted to sell Sindhi woollen textiles in Bombay, and his agent had carried samples of woollens to Bombay on the route through Umarkot. ${ }^{70}$

France too had approached the Hyderabad Meer to propose an alliance, but the Meer preferred to ally with the British because their territories in India were closer to Sindh than were the territories held by France. ${ }^{71}$ Napoleon at this time had ceased to be a threat to the British because he was busy with his campaign against Spain, so the British did not consider an alliance with Sindh for political reasons to be urgent. The Company, therefore, turned down Meer Ghulam Ali's request. Balochistan, (Quetta : Gosha-e Adab, 1977), 209. Letter from Meer Ghulam Ali to Jonathan Duncan, 10 November 1803, Secret and Political Department, no. 150, 6825, National Archives of India [hereafter NAI].

69 Mubarak Ali, 'Umarkot: A Historic City of Sind, Studies on Sind' in Essays on the History of Sindh, (Lahore: Fiction House, 2005), 59, 66. Letter from Meer Ghulam Ali to Jonahan Duncan, 10 November 1803, Secret and Political Department, no. 150, 6828-6829, NAI.

$71 \quad$ Ibid., 6827.
} 
Instead it asked that he compensate the Company for the financial losses incurred by the closure of the Karachi and Thatta factories and the expulsion of Nathan Crow from Sindh in $1800 .^{72}$ Why Duncan took this stand is perhaps explained by the Company's financial difficulties caused largely by Wellesley's expansionist policy.

In 1805, the ruler of Kabul was planning another military incursion into Sindh because its tribute payment was once more in arrears. Again, therefore, Meer Ghulam Ali appealed to Duncan to form a connection with the Company and invited him to re-establish a factory in Sindh. Duncan replied that the return to Sindh of a Company resident was not possible 'considering the present state of public affairs'; there could be no resumption of friendship until the Company received compensation for the expulsion of Nathan Crow. ${ }^{73}$ Sindh hereafter was relegated to backstage while the British pursued their imperial aims in the subcontinent. Dundas preferred working with Afghanistan as a strategy for defending British India, whereas Wellesley favoured winning support from Persia and Sindh (both of which wanted to resist Afghanistan's suzerainty). The Company government of Bombay, dominated by private traders, judged that, if an ally in the Middle East was needed at all, it was better to be allied with the Imam of Oman. It believed, however, that there was no interest in the Middle East for an alliance with the English Company, a view that changed later in the nineteenth century (this will be discussed in the next chapter). When the power of the Imam of Oman became weak the Governor of Bombay considered trading with Persian Gulf merchants instead. ${ }^{74}$

We see, therefore, a policy clash in relation to Sindh between the Bombay Government and the London Foreign Office (including the EIC Board of Control) on the one hand, and the Government of India on the other. British contact with Sindh and Persia was established by lobbyists such as John Malcolm (the envoy sent to Persia by Wellesley) and Wellesley. Wellesley stirred unwarranted alarm about an invasion of India by Afghanistan, and claimed that the threat was real in 1798.

72 Talpur, Talpur Rule in Sindh, 47.

73 Letter from Jonathan Duncan to the Haqim of Sindh, Secret and Political Department, $5^{\text {th }}$ April 1806, no. 183/ 1806, 5132-5139, MSA.

74 Ingram, In Defence of British India, 170. 
Edward Ingram conceded that Wellesley's aim of allying with Persia was to extend the British sphere of influence as far as possible and as a means of countering the Marathas in India. We will see, however, that after Wellesley was recalled to London in 1805, his replacement, Lord Minto (1807-1813), in 1808 sent embassies not only to Persia but to Kabul, Sindh and the Punjab as well. Minto's reasons were that Britain's position in India was threatened by new developments in 1807; specifically, these were the Franco-Persian treaty of 1807, one term of which required France to defend Persia against Russia, and the subsequent Treaty of Tilsit, an agreement that Persia would help France in the event of a French invasion of British India. ${ }^{75}$

Sindh, a tributary of Afghanistan, preferred to submit to the authority of Persia than Afghanistan's. This could have been due to the growing Persian influence at the Sindh court; many Iranians and Georgians had taken refuge in Sindh because of the Afghan menace in the region and Shah Zaman's ambition to seize Khurasan from Persia. ${ }^{76}$ A March 1808 document tells us that Meer Ghulam Ali of Hyderabad approached the Persian king to offer Sindh's allegiance to Persia; he also offered to pay a sum of 12,000 Rupees if the Persians were willing to wrest the suzerainty of Sindh from Afghanistan. ${ }^{77}$ King Fateh Ali agreed to the proposal and set off towards Sindh at the head of an army. Before the Persian army reached the Sindh border, however, Shah Shuja arrived in Hyderabad and collected Rs. 130, 0000 as tribute. There was thus no need for the assistance of the Persian army to forestall the Afghans.

When, in March 1808, Meer Ghulam Ali, realised that he could not prevent the Persian forces from entering Sindh, he sent his agent, Mehr Ali, to Bombay to request help from the English. ${ }^{78}$ Then in October 1808 intelligence was received in Bombay about an alliance between France and Sindh and about a French attack on Rome, including the arrest of the Pope. The French army reached Turkey and were

Ibid.,131.

Ghulam Muhammad Lakho, 'Sindh- Iran Relations', Journal of Pakistan Historical Society, Vol. LVI, no. 1, 2008, 61.

77 Memorandum respecting the letter from the nabob of Scinde, Foreign Department, Secret and Separate Consultations, 24 March 1808, no. 7, NAI. Ibid. 
joined by the Turks for a march towards India through Persia. In the same year the Bombay government learnt that private French sea merchants were active along the coast of Gujarat. ${ }^{79}$ A result of these developments was that Persia lost its importance as an ally on which Sindh could depend for help against Afghanistan. Moreover, at the same time as the Sindh ruler was making overtures to both Persia and the British, the Governor-General of India was becoming anxious to prevent a hostile political alignment taking place on British India's north-west frontier. ${ }^{80}$

The English now needed to act against the French, and the situation in Sindh seemed conducive to action. If it had a Residency in Sindh, Bombay could get intelligence about French intentions and activities in relation to both Sindh and the states to its north such as Qandahar and Kabul. It could also get more information about what the French were doing in Persia. Duncan, the Governor in Bombay, was instructed by the Supreme Government to ensure that the relationship with Sindh was entirely political in nature. The agent or envoy sent to Hyderabad should state that his principal objective was to collect compensation for the loss the Company incurred by the expulsion of its agent in 1800 . This could put the Company in a better bargaining position vis-à-vis the Meers. ${ }^{81}$ It could then establish a factory in Sindh; the factory could serve as a base from which to spy on French advances towards Sindh. The agent was also to ascertain the possibility of Russian forces marching through Sindh to Surat, because any army setting off from Qandahar and aiming to march into India was likely either to pass through Kabul and the Punjab or through Sindh and Gujarat. ${ }^{82}$

On 1 April 1808, Duncan, agreed to forward to the Council of Bombay the offer of an alliance with Sindh; the offer was in a letter delivered to him by Mehr Ali.

79 Report from C. Foote, President of Bombay Harbour, 19 October 1808, Bombay Castle, Secret and Political Department, no. 248, 22 October 1808, 11938, MSA.

80 Foreign Department, Secret and political consultations, 3 October 1808, no. 8, NAI.

81 Foreign Department, Secret and separate consultation, 14 March 1808, no.1, NAI.

82 From Fort William to Jonathan Duncan, Foreign Department, Secret and Separate Consultation no. 1, 14 March 1808, NAI. 
${ }^{83}$ Our sources do not indicate who Mehr Ali was, but from the writings of Parveen Talpur it can be inferred that he was a Talpur official of influence in Hyderabad who was asked by a British agent, Syed Taqi, to mediate an alliance between the Meers and the British. ${ }^{84}$ As well as forwarding the letter to the Council, Duncan wrote to Lord Minto asking that Captain Seaton, the Resident at Muscat, be sent as the Company's agent to Sindh because he was familiar with the Persian language. ${ }^{85}$ Since the British had not had any connection with Sindh since the expulsion of Nathan Crow in 1800 they had not been able to exert any influence at the Sindh court. The instruction to Duncan from Fort William was as follows:

If however the government of Sinde should be averse to the restoration of commercial factory, it would not be necessary to insist on that condition provided the continuance of the envoy in an official capacity in that country could be secured on other terms, our present object being entirely of a political nature. ${ }^{86}$

The mission, therefore, was cloaked as a commercial venture while, in reality, it was political in nature. The British Resident in Sindh was to be a political agent and work at achieving a position of influence at court. His primary objectives were to observe and report on relations between Sindh, France and Persia, and to note any indications of moves from Kabul to collect tribute from Sindh. To achieve these aims, the Resident would need to get the Meers on side. The authorities in Fort William left it to Duncan to decide precisely how to do this; as Governor of Bombay, he was more in touch with the situation in Sindh than were officials in Calcutta. ${ }^{87}$

Seaton was instructed to travel to Hyderabad and begin negotiations with a demand for an indemnity of Rs. 70,000 and a request for permission to open a Letter from Jonathan Duncan to Lord Minto, Foreign Department, Secret and Separate Consultation, no. 2, 16 May 1808, NAI.

$84 \quad$ Talpur, Talpur Rule in Sindh, 48.

85 Letter from Jonathan Duncan to Lord Minto, Foreign Department, Secret and Separate Consultation, no. 2, 16 May 1808, NAI.

86 From Fort William to Jonathan Duncan, Foreign Department, Secret and Separate Consultation, 14 March 1808, no.1, NAI..

87 From Fort William to Jonathan Duncan, Foreign Department, Secret and Separate Consultation, 14 March 1808, no. 1, NAI.
} 
factory. After he had won the goodwill of the Meers and their ministers and personal advisors, he could explain the Company's main purpose. ${ }^{88}$ As noted above, the Governor-General regarded the opening of a factory as less important for British interests at this time than the establishment of a permanent Resident in Sindh. Even so, the Company Directors wanted to expand the Indian market for goods manufactured in Britain. Accordingly, Seaton was instructed by the Board of control to present to the Meers a list of British imports; he was to ask if there was a market for these products in Sindh or if they should be exported to Afghanistan. He was also to be alert to any French intrigues in Sindh. If France should decide to advance on India through Sindh, Seaton was to make an assessment of the military preparation and gun boats that the Company would need to stop French forces at the Indus. He was also advised to win over the trust of Mehr Ali, the agent sent to Bombay by Meer Ghulam Ali, because he had some influence at court, and a friendship with him could be useful to Seaton. ${ }^{89}$

Seaton left Bombay on 28 April 1808 and arrived in Hyderabad on 15 July. Before this, however, Persia (which had recently formed an alliance with France) sent an agent to Hyderabad to forge an alliance with Sindh. This alliance gave the Meers an advantage in negotiations with Seaton. He now had to tone down the Company's demands and offer an alliance on terms different from those specified by the Calcutta Council. He did not press the Meers for an indemnity and proposed an offensive - defensive alliance with them. So the treaty that was signed a month after Seaton's arrival included a clause that required both parties to assist each other with troops when either side needed them. Parveen Talpur argues that the reason for the failure of Seaton's mission was that 'the Meers played well on the fears of Seaton....they showed him a letter of the Shah of Iran, addressed to Meer Ghulam Ali, promising to make him the governor of Kabul and Kandahar if Sindh allied itself with Iran.... For Meers it was thus a diplomatic victory'. ${ }^{90}$ The Meers, caught Separate Consultation, no. 14, 30 May 1808, NAI.

89 Ibid.

90 Talpur, Talpur Rule in Sindh, 49. 
between the British, the French, the Afghans and the Persians, were trying to play a careful balancing game to sustain and expand their rule.

There were further problems with the treaty that Seaton signed. As noted earlier, the Meers had designs on Umarkot and wanted to wrest it from Jodhpur. They also wanted to be freed of Afghan control. The implication of an offensive defensive alliance specified by the treaty was that the Company could be asked to send troops to fight for Sindh against Jodhpur or Afghanistan. This was not acceptable to the Bombay Government because Jodhpur was an ally of the Company, and it was planning to send an agent to Afghanistan to propose an alliance with Kabul. $^{91}$

Seaton's mission also failed to establish a commercial factory in Sindh. A clause of the treaty only stipulated that a Company factory could be established in Thatta with the same privileges it previously had under the Kalhora rulers. The treaty did provide for a Company agent to reside at the Hyderabad court. As things turned out, however, the agreement signed by Seaton was eventually annulled for it did not give the Company what it wanted. Seaton was recalled to Bombay and another British agent was to take his place in Hyderabad. ${ }^{92}$ For their part, the Meers remained interested in forging a friendly relationship with the British. Accordingly, they sent their agent Akhund Bucka to accompany Seaton back to Bombay; the agent was to ask for the Company's assistance or neutrality in the event of an invasion of Cutch by Sindh and to bring back to Sindh a replacement for Seaton. ${ }^{93}$

In October 1808, a few days after Seaton's recall, Colonel Walker, the Resident in Baroda, reported to Francis Warden, the Chief Secretary to the Government of Bombay, that there had been some new political developments in Sindh. Meer Reza was trying to unseat Ghulam Ali and his pretension was supported Elphinstone to Lord Minto, March 8 1809, Foreign Department, Secret and Separate Consultations, 29 April 1809, no. 2.NAI.

92 Governor-General in Council to Jonathan Duncan, Secret and Political Department, Consultation No. 32, 5 December 1808, NAI.

93 Letter from Seaton to Jonathan Duncan, 6 October 1808, Secret and Political Department Consultations. 21 October 1808, No. 12, NAI. 
by Meer Thara, a prominent Talpur Meer. According to Walker, Talpur rule was weak, threatened by internal dissention, and the Meers cared little about their subjects. ${ }^{94}$ Therefore, as happened in other Indian states such as Carnatic before being taken over by the British, the Sindh rulers were judged to be unfit to govern the Sindh state. ${ }^{95}$ And the internecine conflicts within the royal family provided the British with an opportunity to intervene.

Governor-General Minto sent Mountstuart Elphinstone on a mission to Afghanistan in August 1808. But in December from Multan, before arriving in Kabul, Elphinstone wrote an appraisal of the political situation in Sindh and more or less recommended the annexation of the Sindh state. Elphinstone knew about the failure of Seaton's mission. He stressed the need for an alliance with Kabul that would enable the British to close off the Khyber Pass and prevent France and Persia from invading India. A friendly ruler in Kabul would make this possible. Shah Shuja was Elphinstone's choice for the Afghan throne, but a number of factors made this choice problematic.

First of all, although the Afghans wanted the British to support them against Persia, the British found Persia more useful as an ally than Afghanistan. Another complicating factor was Ranjit Singh, the ruler of Lahore, who was hostile to Shah Shuja; the British judged that an alliance with Ranjit Singh was more valuable than an alliance with his rival, Shah Shuja. Ranjit had emerged as a paramount power in Western Punjab (close to British India); now he was extending his territory eastward into Eastern Punjab, and southwards towards the Sindh border. Ranjit Singh also controlled the frontier to Kabul. The only route for an army sent from Bombay to support Shah Shuja in Kabul was through the Bolan Pass in Sindh. ${ }^{96}$ So if the British

A. Walker, Resident of Baroda to Francis Warden, Chief Secretary to Government of Bombay, Secret and Political Department Diary, 22 October 1808, no. 248, 11938-11940, MSA.

95 Edward Ingram believes that Wellesley's design on Carnatic was justified because 'it was notoriously badly governed. For nearly forty years the nabob of Arcot, who lived in a sumptuous palace in the suburbs of Madras, had been borrowing large sums of money at exorbitant rates of interest from most of the Company's servants there, and pledging as his security the land revenues of the Carnatic'. Ingram, Two Views of British India, 7. Ingram, In Defence of British India, 139-142. 
were to achieve their aim of placing Shah Shuja on the Afghan throne, it was necessary to ally with Ranjit Singh, or at least win his consent for their project. Herein lay the importance of Ranjit Singh in the first decade of the nineteenth century. He was also important because his ambition in Sindh later influenced British strategies in north-west India. It will be useful, therefore, to digress a little here and discuss the role played by Ranjit Singh in shaping British attitudes to Sindh.

The Sikh state in the Punjab emerged in the seventeenth and eighteenth centuries at the same time as state formation was occurring in Sindh under the Kalhoras. ${ }^{97}$ Both the Sikh state in the Punjab and the state developed by the Kalhoras in Sindh were rooted in religious sects that grew strong during the decline of the Mughal Empire. The Punjab, like Sindh, came under Afghan suzerainty; it was annexed by Ahmed Shah Abdali in 1752. But while the Talpurs, who unseated the Kalhoras in 1883, remained under Afghan suzerainty, the rise of Ranjit Singh in the Punjab made things different there; Ranjit challenged the Afghans and coveted Sindh.

After the unsuccessful invasion of Multan that he led in 1802, Ranjit Singh established an amicable relationship with the Hyderabad Meers. The other two Sindh states, namely Mirpur and Khairpur, were left out of the alliance. Ranjit Singh was asked by the EIC not to extend his territory eastwards to the other side of Sultuj. ${ }^{98}$ In January 1809, a British contingent under Sir David Ochterlony was dispatched to Ludhiana, on the eastern bank of Sutluj, to guard the border between British India and the Punjab. ${ }^{99}$ The Hyderabad Meers advised Ranjit Singh in 1809 not to ally with the East India Company. But the Meers needed to sign a treaty with the Company in order to protect Hyderabad from the Afghans and to resist Abdul Nabi Kalhora, who was eager to oust the Talpurs from Sindh. ${ }^{100}$ As J. S. Grewal argues, the treaty of Lahore that was signed by Ranjit Singh and C. T. Metcalfe on 25 April

Khuswant Singh, Ranjit Singh, Maharajah of the Punjab, (London: George Allen \& Unwin Ltd., 1962), 16-17.

Letter to Raja Ranjit Singh, Foreign Department, Secret and Separate Consultation, No. 4, 31 October 1808, NAI.

Dharma Bhanu Srivastava, The Province of Agra: Its History and Administration, (Delhi: Concept Publishing Company, 1979), 61.

Ikram Ali Malik, 'Ranjit Singh's Relations with the Amirs of Sindh: 1802-1839', in Sind Through the Centuries, ed. Hamida Khuhro (Karachi: Oxford University Press, 1993), 161. 
1809 demarcated the boundaries of Lahore and the territories held by other Punjab chiefs. ${ }^{101}$ The treaty extended British protection to the Chiefs of Sirhind; that meant that the Bengal presidency's control extended as far as Ludhiana. Ranjit Singh's ambition to extend his territory soon made him disregard this treaty.

Since 1802, there had been exchanges of envoys and expressions of goodwill between the Hyderabad Meers and Ranjit Singh. But what had once been a friendly relationship between the two states slowly went sour. Ranjit Singh annexed Multan in 1818 and then he expanded further southwards, bringing together the frontiers of Sindh and the Punjab. There were clashes between the Baluchis and Sikhs on the border of the Punjab and Sindh in 1823. Hyderabad's annexation in 1823 of Shikarpur, held by Afghanistan until then and coveted by Ranjit, led to a clash between Sindh's rulers and Ranjit Singh. ${ }^{102}$ Ranjit Singh's hostility towards Afghanistan, and his success in throwing off Afghan hegemony, led him in 1826 to claim the tribute that Sindh paid to the Afghan kingdom. ${ }^{103}$ British intervention in the political relationships between Afghanistan, Sindh and the Punjab led to a settlement with Ranjit Singh that entailed his giving up these claims. A discussion of the 'great game' that the British played with the Sikhs, Sindh and Afghanistan is discussed in the next two chapters. The final section of this chapter considers Lord Minto's engagement with the interregional politics of north-west India and Central Asia, and examines Nicholas Smith's mission to Sindh.

\section{Nicholas Smith's Mission to Sindh}

Lord Minto had decided that Britain needed both Afghanistan and Persia as its Middle Eastern allies in order to defend British India against a French invasion, and this required that Britain place a friendly ruler on the Kabul throne. As noted above, the British choice was Shah Shuja, who had previously ruled Afghanistan from 1803 to 1809 . To restore Shah Shuja to the throne, however, the British had to support him

Jasjit Singh Grewal, The New Cambridge History of India, The Sikhs of the Punjab: Eastern India 1740-1828, rev ed. (Cambridge: Cambridge University Press, 1998).

Malik, 'Ranjit Singh's Relations with the Amirs of Sindh', 161. Ibid.,161. 
with subsidies. Elphinstone suggested that this cost could be met from tribute paid to Kabul by Sindh, still one of Afghanistan's client states. In fact, Elphinstone made it a condition of Shah Shuja's restoration that the cost of Britain's subsidies be met from revenue collected from Sindh; Shah Shuja agreed to this. But Elphinstone also had bolder ideas. He favoured the annexation of Sindh by the British; he judged that this was advisable not only because of Sindh's strategic location but also because of the commercial importance of the river Indus in Sindh; he was already talking about how to make the river more navigable, ${ }^{104}$ a project that was later carried out by Alexander Burnes in 1831.

Lord Minto, however, was against the outright annexation of Sindh because, in his view, an alliance with Kabul became less important as France become busy with affairs in Europe (especially rebellion in Spain) and, therefore, as Persia lost hope of any aid from France. The British now hoped that they could win Persia as an ally. ${ }^{105}$ Even so, although friendly relations with Afghanistan were not as desirable for the British as before, Minto still thought it expedient to get Afghanistan on side in case the French danger should resurface. And then there was the Russian threat. Russia once had designs on India; its boundary now extended to the Caspian Sea and it had taken the city of Erivina from Persia. France's military resources were fully deployed in the Napoleonic wars but, after the Franco-Russian Treaty of Tilsit in 1807, the Russian army could be asked to advance French aims in Central Asia and India. For the British, therefore, an alliance with Afghanistan could still be useful, but only if the Kabul regime did not turn against Persia. Broadly, the Company's position in the late 1810s, when France was bogged down in Europe, was that an alliance with Sindh had little immediate usefulness but that it could be useful in the longer term. ${ }^{106}$

Nicholas Hanky Smith, the former Resident of Bushire, was appointed as the Company's agent in Hyderabad; he was sent there with the instruction to establish a 
permanent connection with the Sindh state. He was also instructed to be authorative and firm in his dealing with the Talpur Meers and to use any internal conflict that he found there to the Company's advantage. ${ }^{107}$ Smith was accompanied by Lieutenants Robert Taylor, Henry Pottinger and Henry Ellis, who served as his assistants. Included in the party were two surveyors tasked with writing a report on the Indus river's navigability and surveying Hyderabad's geographical features, natural resources and military capabilities; they were told to do their surveys without raising the Meers' suspicions about the British. ${ }^{108}$

On 10 May 1809 Smith's entourage arrived at Karachi aboard two armed ships; the sight of the ships caused considerable alarm among Sindhi government officials, and the Meers immediately became suspicious of the British mission; they sent an army unit to protect the fort at Karachi. Smith was told that his party could not proceed to Hyderabad unless the armed ships were sent back to Bombay. After negotiations, however, the mission was allowed to proceed to Hyderabad. ${ }^{109}$ It reached Thatta on 16 June, and from there continued the journey in two groups. Smith took the land route to Hyderabad; the other group, which included Pottinger, Ellis and William Maxfield, proceeded by sailing up the Indus. This was for the purpose of surveying the river routes from Thatta to Hyderabad and mapping the course of the Indus.

A few days after Smith's arrival in Hyderabad, on 8 August 1809, the Meers received intelligence from their agents in Jodhpur and Bahawalpur that Company ships, under the command of Colonel Walker, and deployed to clear the coast near Cutch of sea robbers, were soon to head towards Sindh. This further alerted the Meers' suspicions; an EIC foothold in Hyderadad could not only provide the British with an opportunity for spying on the Sindh government, but also serve as a base from which they could form alliances with Sindh's neighbours against Sindh. The November 1808, no. 10, NAI. 1808 , no. 36 , NAI.

109 Sir Henry Pottinger, Travels in Beloochistan and Sinde; Accompanied by a Geographical and Historical Account of Those Countries (London: Longman, 1816). 342-355. 
Meers were considered dismissing the mission, and Smith even began preparing to head back to Bombay. In the end, however, the Meers decided to go ahead with the alliance. ${ }^{110}$

A group of local merchants opposed the establishment of a British factory in Sindh. They remembered the privileges briefly granted by the Meers to the British in the late 1790s, and felt that the establishment of a Company factory in Sindh would result in unfair competition and damage to their businesses. However Haji Umar, a successful trader and a close associate of Meer Murad Ali, allied with the British. Back in 1799 he had helped Nathan Crow in his endeavours to re-open Sindh to the Company. He now passed to Smith valuable information about what was happening in the Talpur court. He told him that neighbouring states such as Jodhpur were sending their agents to Hyderabad to inform the Meers of what the British were doing in their home states. Haji Umar also gave Smith access to the Sindh state revenue records. On several occasions he helped Smith in ways that ensured the success of his mission. Our sources do not indicate why he helped the British. There is no doubt that Sindhi merchants found very burdensome the range of heavy transit duties they had to pay on goods passing through the territories of various Meers. But many of them were still not prepared to support the British against the Talpur regime. Smith also found an ally in the court of one of the government ministers, Wali Muhammad Laghari. He sided with the British and championed their cause in the face of opposition from the trading community of Sindh, representatives of which had approached the Meers against the British. ${ }^{111}$

It is likely that, in the early 1800 s, Sindhi merchants did not see any good reason for backing the Company. They changed their stance when Britain, after subduing most of the Indian subcontinent, emerged as the major player in the power politics of north-west India Canny merchants came to realise that siding with the British could have benefits for them in the marketplace. A prime example is Seth

\footnotetext{
$110 \quad$ Ibid.

111 Pottinger, Travels in Beloochistan and Sindh, 350-351.
} 
Naomal Hotchand Bhojwani, whose background is outlined in Chapter $3{ }^{112}$ The British plan to open up the Indus to trade traffic was also attractive to Sindhi merchants. So we find that the merchants who had flourished in the eighteenth century Sindh, people whom Christopher Bayly and Sanjay Subrahmanyam call 'portfolio capitalists', came to align themselves with the Company in the early $19^{\text {th }}$ century because their interests coincided with those of the Company. ${ }^{113}$

The Meers and Smith negotiated for more than a month before signing a treaty. Letters that passed back and forth between the two parties addressed issues such as the opening of a Company factory and an alliance between Sindh and Britain against France. The Meers would allow the Company to establish a factory as long as it assisted an invasion of Cutch. On the other hand, if the British wanted an alliance with Hyderabad against the French, it should remain neutral on the Cutch issue. ${ }^{114}$ Backing a Sindh invasion of Cutch was ruled out by Smith, because Company policy was to maintain friendly relations with neighbouring states. ${ }^{115}$

A treaty was finally concluded between the Company and the Meers on 22 August 1809. Its first clause provided for the establishment of friendship between the British and the Meers of Sindh - that is, Meer Ghulam Ali, Meer Karim Ali and Meer Murad Ali. It provided for the mutual exchange of agents on a regular basis. And it declared that the French 'tribe' would not be allowed to establish themselves in Sindh. ${ }^{116}$ The Meers did not agree to the establishment of a British Residency in Sindh, but the British were not too concerned about this; one of their key objectives was to collect intelligence in Sindh, and this could be achieved through the mutual

112 See Chapter 3of the thesis and Naomul Hotchand and H. Evan M. James, A Forgotten Chapter of Indian History as Described in the Memoirs of Seth Naomul Hotchand of Karachi ..., (Karachi: Oxford University Press, 1982).

113 C.A. Bayly and S. Subrahmanyam, 'Portfolio Capitalists and the Political Economy of the Early Modern India', Indian Economic Social History Review, 25, 1988, no. 4, 401-424. By 'portfolio capitalist' Bayly and Subrahmanyam mean the class of intermediaries that emerged during the declining phase of the Mughal empire. The class facilitated the rise of British imperialism in India by giving financial assistance to the British empire builders. The 'portfolio capitalists' declined, however, during the colonial period.

114 Secret Consultations, 7 August 1812, no. 5, NAI.

115 Foreign Department, Secret and Separate Consultations, 12 December 1809, no. 8., NAI.

116 Aitchison, A Collection of Treaties, Engagements and Sunnuds, p. 35. 
exchange of agents. Furthermore, the Meers did permit a native Indian to serve as the Company's resident in the Hyderabad Court. Accordingly, Smith appointed Munshi Muhammad Yusuf as the British resident; Muhammad Yusuf's task was to send to Bombay information about political developments in Sindh and the state's relations with the French. ${ }^{117}$ Smith left Sindh on 25 August 1809; his party included an agent who was to serve as the Meers' agent in Bombay. ${ }^{118}$ Thus started a mutual exchange of envoys between Hyderabad and the Company, and this arrangment remained in place until the permanent establishment of the British Residency in Sindh in 1838.

\section{Conclusion}

During the Napoleonic wars period, one of the Company's chief concerns was to form alliances against France with countries lying between Persia and British India. To this end, Captain Harford Jones was sent on a mission to the court of Persia. Wellesley also wanted to prevent the Russians from expanding in the Caucasus. Persia had asked for British aid against Russia; Wellesley responded by strengthening ties with Persia, and the medium chosen for this was trade. The option of sending an Indian army to Persia was also considered as a means of strengthening the Persian state against predators. ${ }^{119}$

For Wellesley's successor, Lord Minto, it was difficult to choose a Middle Eastern ally because all of the potential allies were in conflict with each other. Therefore, he chose to form connections with the most strategically important. As a consequence, missions were sent to both Persia and Afghanistan. Sindh was also needed as an ally because it was strategically located between British India and the Middle East and had great potential for trade; the Company traders at Bombay had recognised this early on. Connections with states west of Lahore and with the Sikh chiefs were also established by Lord Minto. The Company stated that its policy was to establish peaceful and friendly relations with these powers, so the connections established with them were defensive in nature. The Company also declared that, in

\footnotetext{
117 Secret Consultations, 7 August 1812, no. 5, NAI.

118 Secret Consultations, 7 August, 1812, no. 19, Enclosure 14, 22 August 1809, NAI.

119 Ingram, In Defence of British India, 166.
} 
case of wars among these local powers, it would act as moderator of the conflicts and not take up arms on behalf on one side against another. The Company, however, did try to play on the weaknesses of the tribes of Sindh. Its strategy was to establish EIC emissaries in the states to the west of British India and, through them, to obtain intelligence about the internal politics and dispositions of the rulers of each state. ${ }^{120}$ The attitude of individual British officials towards the various Indian powers, including the rulers of states in the north-west such as Sindh, played a role in shaping the relationship that the East India Company developed with them.

Chapter 5 will explore the possible connection between weakness in the Sindhi polity and the rise of the British in Sindh. It will consider whether private traders played a role in shaping the dominant British voice towards annexation. And it will show how the Meers tended to invite British aid whenever a threat from Afghanistan and the neighbouring state of Punjab seemed imminent. Particularly important was the way in which Britain's 'great game' strategy during 1820s and 1830s elevated Sindh's importance in the eyes of the British; the Indus River came to be seen as crucial as an access route for the defence of British India and as a trade route. Consequently, a survey of the Indus became increasingly urgent. I will argue that the survey begun in the early 1830s facilitated the annexation of Sindh in 1843. 


\section{Chapter 5}

\section{The Survey of the Indus and the Development of British Commercial Interests in Sindh}

In the last chapter we saw how Sindh became enmeshed in Britain's empire building. First, when the British needed to counter the French and then the Russian advance into India, it became part of Britain's 'great-game' in Asia. Secondly, geo-political factors made Sindh a target of the East India Company's political and commercial ambitions, the furthering of which came to win support from Sindh's mercantile class. The Sindhi merchants were at first hostile to the Company, but their attitude changed as the British emerged as more powerful than any of their rivals in South Asia; the merchants then saw that their interests would be served by supporting the British.

Pamela Nightingale's study of Western India shows the connection between trade and annexation. The Company's Bombay traders were involved in the profitable cotton trade along the Malabar Coast and in Gujarat. Nightingale argues that the 'imperialism of the private traders' was a contributing factor in the British annexation of that region. ${ }^{1}$ In Rudrangshu Mukherjee's view, the Company's trading interests also contributed to the truncation of Awadh in $1801 .^{2}$ Not all analyses of British expansion in India, however, give primacy to economic factors. P.J. Marshall notes that a 'jaundiced contemporary with long service in Awadh' attributed the annexation of Awadh to Wellesley's 'desire of fame'. ${ }^{3}$ And a similar explanation of the annexation of Sindh has been offered by H.T. Lambrick; he says that the pursuit of 'glory' by Charles Napier, commander of the Indian army in Sindh, led to the

Pamela Nightingale, Trade and Empire in Western India: 1784-1806 (London: Cambridge University Press, 1970), 207-208.

Rudrangshu Mukherjee, 'Early British Imperialism: A Rejoinder', Past and Present, Feb. 1985, no. 106, 169-173.

P.J. Marshall, 'Early British Imperialism in India', Past and Present, Feb 1985, no. 106, 169. 
annexation of the Sindh state in $1843 .{ }^{4}$ The validity of these arguments will be considered in Chapter 6.

In this chapter we will discuss a number of other factors that facilitated British expansion in Sindh. One was domestic conflict and instability. C.S. Srinivasachari's study shows that political rivalries among the 'nawabs' in Carnatic led to British interventions in the politics of the region. ${ }^{5}$ The same applied in Awadh and Bengal. And conflict among the Talpur Meers was used by British to gain a foothold in Sindh. As well there were the regional political rivalries such as those between Sindh, Afghanistan and Persia and, more broadly, the rivalries between Britain, France and Russia. We need to consider, also, the role played by differences of opinion within the Company bureaucracy. While varying in importance, all of these factors contributed to the gradual entrenchment of the British rule in the Sindh.

In the first half of the nineteenth century British policy in relation to Sindh was shaped by the need to forestall the French threat to British India. Once the French threat to India was mitigated by Napoleon's defeat in 1815, the Company's reason in 1809 for forming an alliance with Sindh no longer existed. In 1820, however, events in Cutch, gave cause for another treaty between the two. Cutch, a British protectorate since 1818 , was attacked by bands of marauders and brigands from Sindh in $1819 .{ }^{6}$ During the first two decades of the nineteenth century, the situation in Cutch played a large part in determining British policies in western India and Sindh; this will be demonstrated in the following pages. The British 'great game', a response to international developments such as French and Russian expansionism, will also be analysed, as will the political, economic and local conditions that help explain the annexation of Sindh in 1843. 34. C.S. Srinivasachari, The Inwardness of British Annexation in India ( Madras, University of Madras, 1951).

Letter from Acting Resident at Bhooj to Metcalfe, 23 May 1820, Secret Consultation, 22 July 1820, No.4, National Archives of India [hereafter NAI]. 


\section{Sindhi raiders and the British}

As discussed in the previous chapter, the government of Bombay in the 1700s believed that no ally was needed in the Middle East for the security of British India. That government was dominated by private traders who put the interests of their commercial enterprises ahead of the interests of the Company, was a point made by scholars such as Edward Ingram and Pamela Nightingale. ${ }^{7}$ Nightingale's work on British trade in western India shows that, until 1806, the government of Bombay was still not completely under the authority of the governor-general in Bengal. Between 1784 and 1806 it expanded its control into western India as well as northward. This expansion was driven by trade imperatives and did not have the sanction of the Court of Directors, which lacked funds to invest in Bombay. ${ }^{8}$ Michael H. Fisher suggests that, the reason why the British government and the EIC Directors repeatedly opposed further annexations in the early nineteenth century was because territorial expansion in India was so costly; the Company's debt had tripled during the 1798 and 1806 period. ${ }^{9}$ Archival records show that the Directors were even ready to reduce military expenditure at the cost of the security of Company personnel and property. ${ }^{10}$ A military scale-down was feasible because, by 1810, the Company could feel fairly secure in India; the French navy was less threatening, good relations had been established with Persia (thanks to the initiatives of Lord Minto), and the British had firm control over all of the major Indian states. The Directors, therefore, suggested to the Governor-General a reduction of the native infantry in Madras and Bombay. ${ }^{11}$

The initiative of private traders, however, continued to shape the Company's agenda. Its growing control of Gujarat and Kathiawar, the result of initiatives taken by private traders in Bombay, gave it an opportunity to expand its raw cotton and

Edward Ingram, In Defence of British India: Great Britain in the Middle East, 1775-1842, (London: Frank Cass, 1984), 126; Nightingale, Trade and Empire, 243.

Nightingale, Trade and Empire, 240-243. Michael H. Fisher, The Politics of British Annexation in India: 1757-1857 (Delhi: Oxford University Press, 1993), 33.

10 Will Astell to the Governor-General in Council, Secret Letter from Court, 7 July 1810, NAI. 11 Ibid. 
opium trade to Canton by $1809 .{ }^{12}$ Once their trading network stretched to Gujarat, Cutch and Kathiawar, the government of Bombay became concerned about protecting its sea trade from Sindh pirates who infested the Arabian Sea. Robert A. Huttenback tells us that, in 1814, the government of Bombay expressed its concern to the Governor-General that these pirates were encouraged by the government of Sindh. ${ }^{13}$ It is not surprising that this kind of allegation was made against the Meers of Sindh. Nightingale notes that a similar allegation was made in 1805 by Major Alexander Walker, commander of the Bombay military troops in Gujarat, against the native government of Kathiawar. Walker suggested to Jonathan Duncan, the governor of Bombay (1796-1811), that Kathiawar be annexed because its ruler was encouraging pirates, creating an obstacle to Company trade there. Predictably, the piracy problem was used by the Company to justify its intervention in local politics. As Nightingale's study shows, by 1806 Walker succeeded in obtaining most of Gujarat's major trading ports and parts of inland Gujarat and Kathiawar. ${ }^{14}$ The rulers of Sindh and the British came close to waging war over the activities of Sindhi tribal raiders in June 1820; warfare was forestalled by G.F. Sadlier, sent to Sindh by the Bombay government to improve British relations with the Meers. The Sadlier mission to Sindh needs to be understood in the context of British trade and expansion in Gujarat and Cutch. This deserves some attention here.

The Company's interference in Cutch started in 1802. In that year, the state of Baroda, contiguous to the region of Cutch and ruled by the Gaekwads, became a dependency of the Company. ${ }^{15}$ This extended the Company's sphere of influence further into western India, and brought Cutch within its purview. At the beginning of the nineteenth century, Cutch's ruler was Maharao Rayadhanjee (1778-1813), but his authority was weak in several parts of Cutch - in districts such as Bhuj, Mandavee and Lakhput Bunder. The nobles who administered these places were called Bhayats

\footnotetext{
$12 \quad$ Nightingale, Trade and Empire, 233.

13 Robert A. Huttenback, British Relations with Sindh: 1799-1843 (Berkeley and Los Angeles: University of California Press, 1962), 13.

$14 \quad$ Nightingale, Trade and Empire, 232.

15 Summary of Proceedings respecting Cutch from 1802 to 1804, Foreign Department, Political Consultations, 6 March 1809, no.3, NAI.
} 
(members of a brotherhood); they had autonomy in judicial, fiscal and executive matters. ${ }^{16}$ There were fourteen such Bhayats in Cutch; the Cutch ruler exercised direct control only in land not under the Bhayats (referred to as Khalsa). ${ }^{17}$

The Company became interested in Cutch in the early 1800s, when Lord Wellesley was Governor- General, because the political situation there was in flux. Hansraj, the Governor of Mandavee, had approached Captain Montgomarie, Wellesley's bodyguard, to solicit Company help in securing Bhuj, a Cutch tributary. ${ }^{18}$ This is a classic example of a native Indian ruler asking for British help to extend his territory; the Meers did the same when they sought to annex Cutch in 1808-1809. ${ }^{19}$ Wellesley sent Captain Seaton to Cutch to obtain information about the political situation there. Seaton's report concluded that the finances of the Cutch state were in deficit, and so its acquisition could add to the Company's economic difficulties. On the other hand, there were commercial and political benefits to be had. First, Cutch had trade relations with the coast of Africa. Second, there was the danger of the state falling under French influence, and the Company was intent on keeping the French out of India. ${ }^{20}$

Fateh Muhamad, the Governor of Bhuj, and Hansraj, the Governor of Mandavee, both wanted the Company to establish a residency in Cutch, as they were apprehensive of attacks from either Sindh or Kathiawar. Fateh Muhammad, who was at war with Hansraj, was even ready to make peace with him if the Company was willing to act as guarantor. ${ }^{21}$ Seaton arranged a meeting with the two protagonists, and both agreed to end their war. Seaton hoped that his peace-making could win for the Company the friendship of the two governors. He reported to Bombay that any future overtures made by Cutch to the Company should hold promise of profits for the Company, and he waited for instructions about further action. The government of

Ibid., 3.

Ibid., 3.

Summary of Proceeding respecting to Cutch from 1802-1804, Foreign Department, Political Consultation, 6 March 1809, no. 3, 1, NAI.

Letter from Seaton to Jonathan Duncan, 6 October 1808, Secret and Political Department Consultations. 21 October 1808, no. 12, NAI.

Ibid., 21.

Ibid., 22. 
Bengal under Wellesley, however, made no decision about further action in relation to Cutch. And Sir George Barlow, after assuming the Governor-Generalship (Acting), announced in July 1806 that there would be no further intervention in Cutch because the government of Cutch did not ask for it. ${ }^{22}$

Wellesley's forward policy in western India was dropped by Sir George Barlow and also by Lord Minto who succeeded him as Governor-General. No further expansion of British territorial possessions occurred until the time of the Lord of Moira, later Lord Hastings, who succeeded Minto in 1813. In his diary on 31 December 1815, Hastings wrote that his goal was the subordination of all the independent powers of India. ${ }^{23}$ Michael Fischer describes Hastings' policy as one of 'paramountcy'; that is, he justified the annexation in India on the grounds that the Company was the paramount power in India. ${ }^{24}$ Neither the British authorities in Calcutta nor the Board of Control in England supported the goal of making Britain the supreme power in India, but they did want to subdue the Pindaris whom they judged to be disrupting law and order and threatening the security of British subjects in India.

After subduing the Gurkhas (from1813 to 1816) and the Marathas in the Anglo-Maratha wars (1817-1818), Hastings started the work of establishing 'order' in the subjugated areas, and in accordance with British ideas of 'order'; he did this with the help of his officials such as Thomas Munro, Charles Metcalfe, John Malcolm, David Ochterlony and Lord Elphinstone. ${ }^{25}$ These officers also played roles in the affairs of Sindh, some of them working as envoys and others as strategists who pondered the Company's policy options in relation to the still unconquered regions north-west of British India. ${ }^{26}$ Before we look at what the Company's option were, it

22 Ibid., 22-25

23 Mohan Sinha Mehta, Lord Hastings and the Indian States: Being a study of the British Relation of India with the Indian States, 1813-1823 (Bombay: D.B. Taraporevala Sons, 1930), 252. Fischer ed., The Politics of the British Annexation, 21. Ibid., 163. See Michael H. Fisher, 'An Assessment of the Annexation by John Malcolm' in Michael H. Fischer ed. The Politics of the British Annexation, 50-59. Elphinstone suggested the 
will be useful to consider how British interests clashed with those of Sindh's rulers, and how Lord Hastings avoided going to war with the Talpur Meers at a time when the British had still not secured a foothold, political or commercial, in Sindh. ${ }^{27}$

British intervention in Cutch was called for when the Talpurs wrested Umarkot from Jodhpur in 1813 and soon after extended their sway over other regions in the Thar Desert such as Islamkot, Mithi and Diplo. They also made the region of Nagar Parkar a Sindh dependency. The desert region was home to tribes such as the Khosas and Lunas who survived by plundering neighbouring Cutch and Kathiawar. In 1819 they raided British held territory in Cutch. ${ }^{28}$ Captain McMurdo, the commander of the British troops, was instructed to deal with the raiders, but the Meers of Sindh intervened. They sent a letter to the British giving the assurance that they would prevent the raiders from making further raids into Cutch. But in 1820 the Khosas from the Sindh-held region of Parkar again raided Cutch. This time the British took action; troops under the command of Lt. Col Barclay were sent to Nagar Parkar. When news of the British action reached the Meers, they themselves despatched troops to deal with them. The Sindhi troops killed many members of the Khosas tribe in the Taraisura region of Parkar and captured their chief. ${ }^{29}$

But the British thought that the forces garrisoned at the Sindh border, forty miles from the British camp, were the raiders and promptly launched a night-time attack on them, taking a number of them captives. The British then realised that their captives were the Meers' soldiers. ${ }^{30}$ British officers were sent to the Meers to explain the mistake, offer compensation and propose that the British and the Meers act together against the Khosas ${ }^{31}$ Before the British could negotiate with the Meers,

annexation of Sindh in 1809; Lord Minto, however, ruled this out. Edward Ingram, In Defence of British India, 142.

27 George Ross-of-Bladensburg, The Rulers of India: the Marquess of Hastings (Oxford: Clarendon Press, 1900), 186.

28 Letter from T. Warden, Chief Secretary to Charles Metcalfe, Secretary, Secret and Political Department, Fort Williams, Secret Consultations, 22 July 1820, no. 4, NAI.

29 Letter from J. Williams, Acting Resident, Baroda to Francis Warden, Chief Secretary to Bombay, 13 May 1820, Foreign Department, Secret Consultations, 15 July 1820, no.2, NAI. Ibid.

Letter from Miles to F. Warden, 21 June 1821, Secret Consultations, 12 August 1820, no. 5, NAI. 
however, another Sindh force was dispatched to launch a retaliatory attack on the British; it plundered and burned the British-held village of Luna in Cutch. ${ }^{32}$

The incident at Luna changed the Bombay authorities' attitude to Sindh. They now judged their action against the Sindhi troops to have been justified. ${ }^{33}$ The Meers, for their part, chose to back off; they did not want to push the matter further and, instead, sought to re-establish the relationship with the British defined by the 1809 treaty. They chose Maan Singh to lead a mission to Bombay and deliver to the Bombay Governor a letter that explained the intentions of the Meers. The mission was to travel to Bombay via Bhuj, but it halted in Bhuj. Maan Singh contacted Captain W. Miles, the British resident there, and requested his help. Miles was asked to deliver the Meers' letter to the Governor and to give his backing to what the Meers proposed. Miles gave an assurance of British-Sindh friendship, and Maan Singh's entourage returned to Hyderabad. ${ }^{34}$ The Meers, however, now wanted the British to send an agent to Hyderabad; his role would be to consolidate the good relationship between the Company and the Meers, to help devise plans for eliminating the Khosas problem, and to deliver compensation to the Meers for the losses they suffered in the British attack at Luna. ${ }^{35}$ So in July 1820 another Sindh mission was dispatched to Bhuj, this time led by the wazir Sayyid Ismael Shah and Daulat Rao. The evoys met with the new Resident, J. Williams, and conveyed to him the Meers' claim that Cutch had once been under the suzerainty of Sindh. The Meers' proof of this claim was a seventh century text titled Chach Nama (an account of the Arab conquest of Sindh written by Qazi Ismail). The Meers seemed to be claiming Cutch from the British, and this was strongly resented by Williams. ${ }^{36}$

32 Letter from Acting Resident at Bhooj to Metcalfe, 23 May 1820, Secret Consultations, 22 July 1820, no.4, NAI.

33 Letter from W. Miles, Acting Resident at Bhooj to Charles Metcalfe, 23 May 1820, Secret Consultations, 22 July 1820, NAI.

34 Letter from F.Warden, Chief Secretary to C. I. Metcalfe, 27 May 1820, Secret Consultations, 15 July 1820, no.2, NAI. Ibid.

Letter from F. Warden to Metcalfe, 13 May 1820, Secret Consultations, 15 July 1820, no. 1, NAI, From J. Williams to Francis Warden, Chief Secretary to the Government of Bombay, 2 July 1820 , no. 4 , NAI. 
The Governor in Bombay decided to play for time; he said that 'the mission of an envoy [to Sindh] under the present circumstances could be an invitation to insult'; the Meers should themselves seek reconciliation by apologising and compensating the British for the attack on Cutch by paying a lakh or two of rupees; the actual amount should be fixed by the acting Resident at Bhuj. The British had acted in self-defence at Luna; moreover, the Meers had failed to deal with the raiders themselves. Even so, as a gesture of good will, the British would be willing to pay for the losses suffered by the Sindhi force if the Meers agreed to the British terms. If they did not, then a war with Sindh might ensue. Frances Warden, Chief Secretary of the Government of Bombay, suggested to Charles Metcalfe, the Secretary of the Secret and Political Department at Fort Williams, that an army of 10,000 infantry and 2,000 cavalry should be prepared to enter Sindh through Cutch. A cruiser and a few gun boats with some provisions for the army were to sail to Thatta before they proceeded up river to Hyderabad. A reserve force made up of European soldiers (half a regiment) and two native battalions with a team of Gaekwar horses was also to be kept in Cutch and used later to threaten unprotected regions such as Parkar on Sindh's frontier. ${ }^{37}$

Warden suggested to Metcalfe that if a war did happen then Meer Shohrab, who ruled Upper Sindh, could be easily won over to the British side as he wanted to be free of the Hyderabad Meers' overlordship. ${ }^{38}$ The Meers were divided among themselves and it would not be difficult for the British to cultivate defectors. As noted earlier, a similar situation pertained in Carnatic, where rival members of the ruling dynasty sided with the European powers. C.S. Srinivasachari points out that the only difference was that in Carnatic two European powers, the English and the French, were involved, whereas in Sindh only the English were embroiled in power

37 Letter from T. Warden, Chief Secretary to Charles T. Metcalfe, Secretary, Secret and Political Department, Fort Williams, Secret Consultations, 22 July 1820, no. 4, NAI. 
struggles among the Meers. ${ }^{39}$ Michael H. Fischer's study of Awadh shows the same thing happening there. In 1798 the Begums of Awadh turned to the Company Resident for help in replacing the then nawab, Asaf al Daula, with Sadat Ali Khan. ${ }^{40}$

Another of Warden's recommendations was that the British could form a regional alliance against Sindh. Jaiselmer, he suggested, could join the British because it wanted to put a stop to raids across its border by the Baluchis of Sindh. Bahawalpur, also, would be happy to have a British state as its neighbour because it needed British help against the ambitious ruler of the Punjab, Ranjit Singh. Another likely ally of the British was Maan Singh, the ruler of Jodhpur, who was keen on regaining Umerkot from Sindh. ${ }^{41}$

The Meers also made military preparations when they learnt that the British were contemplating an attack on Sindh. ${ }^{42}$ Shah Shuja-ul-Mulk, the deposed king of Afghanistan who was in exile in the Punjab, advised them not to go to war with the British. Meer Sohrab's son, Meer Mubarak Khan, and Meer Thara (d. 1829), the ruler of Meerpur, advised Meer Ismael to settle their differences with the British amicably because they must know that the British could not be defeated militarily. Moreover, the Meers' soldiers were not paid, so their loyalty could not be guaranteed. ${ }^{43}$ The Meers also anticipated that the Durranis and Afghans, their neighbours, might not help them in a stoush with the British. To forestall a British attack, therefore, the Meers sent Miran Muhammad Kazi to Ayub Shah Durrani, the ruler of Afghanistan, with a request for military aid. The annual tribute that Sindh was obliged to pay the ruler of Afghanistan had not been paid for the last two years. Ayub Shah agreed to provide military aid to the Meers if they paid the tribute they C.S. Srinivasachari, The Inwardness of British Annexation in India (Madras: University of Madras, 1951), 70-87.

$40 \quad$ Michael H. Fisher, 'British Expansion in North India: The Role of the Resident in Awadh', Indian Economic and Social History Review, Vol XVII, No.1, 1981, 74.

41 Letter from T.Warden, Chief Secretary to Government of Bombay to Charles T. Metcalfe, Secretary to Government, Fort Williams, Secret Consultations, 23 September 1820, no.9, NAI.

42 Translation of a letter from Muhammad Usuf Munshi, native agent at Hyderabad to Captain Wilson, Assistant Resident at Bhooj, 16 May 1820, Political Department, 3 June 1820, no. 10, NAI.

43 Ibid.
} 
owed as well as the tribute for the next year. The Meers were also asked to support the Afghan army sent to the Punjab to flush out Shah Shuja. ${ }^{44}$ The Meers accepted these conditions and so Afghanistan despatched to Sindh a military contingent commanded by Azeem Khan. ${ }^{45}$ The Meers, alarmed by the fact that the British were communicating with Shah Shuja made their own preparations for a war against the British. They were ready with a force of approximately nine thousand infantry at Karachi and about two thousand infantry at Parkar. ${ }^{46}$

The Supreme Government in Bengal, however, decided that a war with Sindh would be unjust, because the sincerity of the Meers in seeking a friendly relationship with the British could not be doubted. The Governor General in Council wanted to settle the differences with Sindh without resorting to force. ${ }^{47}$ Metcalfe pointed out in a letter to Warden that although the Meers might be militarily weak, they had available to them the option of retreating to parts of Sindh that were not known to the British. Also, the British had no influence in the Hyderabad court at this time. An annexation, therefore, was not feasible. Accordingly, the Governor General in Council rejected the idea of preparing for war against Sindh because a war would achieve little and be expensive. ${ }^{48}$ The Government of Bombay was asked to drop the idea of annexation and instead to meet with Sayyid Ismael Shah, the Sindh agent sent to Bombay in July 1820 by the Meers. ${ }^{49}$

Sayyid Ismael Shah said that he had come to Bombay to give a proper explanation of the Meers dispute with the British, and to report that the Meers would be moving predatory tribes people, about 12,000 in total, away from the frontier, and resettle that area with more peaceful tribes. The Meers would ensure that there would

Ibid., 35-36.

Letter from Sadlier to the Governor of Bombay, 8 February 1821, Political Department, Vol 47/56, 1820-1821, 74, Maharashtra State Archives [hereafter MSA].

From J. Williams to F. Warden, Chief Secretary to the Government of Bombay, Secret Consultations, 9 September 1820, no. 5, NAI.

C.T. Metcalfe, Secretary to Government to Francis Warden, Chief Secretary in Government of Bombay, Secret Consultations, 22 July 1820, no.7, NAI. Ibid.

Letter from Francis Warden to Metcalfe, Secret Consultations, 7 July 1820, no. 1, NAI, Metcalfe, Secretary to Government to Warden, Chief Secretary to the Government of Bombay, Secret Consultations, 7 Oct 1820, no. 3, NAI. 
be no raids across the Sindh border into British territory in future. ${ }^{50}$ Sayyid Ismael Shah invited a British envoy to Sindh to work out ways of establishing amicable relations between the two governments again. ${ }^{51}$ A British mission to Sindh could serve several purposes. For example, it would put in place measures to ensure that the British be allowed to take action against any people from Sindh who raided Cutch, or fugitives from Cutch who sought refuge in Sindh. It could apply to the Meers for permission to garrison their troops in the Parkar region and so prevent plundering raids from that region into Cutch. G.F. Sadlier was selected to lead the mission to Sindh; he left Bombay on 5 December 1820 and arrived at Karachi on 16 December where he was joined by Sayyid Ismael Khan. After another five days on the road the mission reached the outskirts of Thatta; the Meers had sent their officers to greet Sadlier here and to conduct Sadlier's 'istakbal' (welcome) for him. ${ }^{52}$

From Thatta the mission headed to Hyderabad, where a rumour was circulating that stirred up anti-British sentiment. The rumour was that the British had arrived in Sindh with five hundred tents and were waiting for ships carrying troops that would attack Sindh. A meeting was fixed between Sadlier and the Meers for 16 January 1821. Sadlier later reported to Bombay that there was a clique in the Meer court that was hostile to the British and that was intriguing against him. ${ }^{53}$

The Meers told Sadlier that they wanted a close alliance with the British. Sadlier's reply was that any friendship with the Meers would depend on their efforts against the Khosas and other freebooters. The Meers gave an assurance that the Khosas would be removed to the region of Chandka, a pargana west of the Indus in the Larkana region. With regard to property stolen from Cutch by Sindhis, the Meers said that they had found the stolen property and it would be restored to its owners. ${ }^{54}$ But the proposal of a British-Sindh alliance against Afghanistan was rejected by the

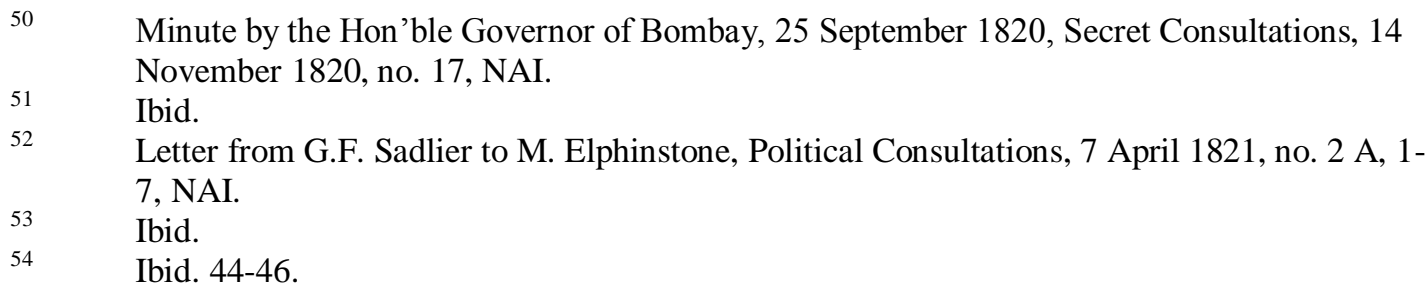


British; their policy was not to extend their engagements beyond the Runn and the Thar desert of Cutch. ${ }^{55}$ The Meers, however, demanded that the danger of an Afghan invasion of Sindh was a more urgent matter for them; they could not take action against the Khosa freebooters until they had dealt with the Afghans. Obviously the Meers were trying to play one adversary against the other. Sadlier observed that every Meer had his own ministers, and this often made it difficult for them to reach agreement on contentious issues. ${ }^{56}$ This was in sharp contrast to the first quartet of Hyderabad Meers in the 1780s - the 'four friends' among whom there was no difference of opinion. ${ }^{57}$ The disunity that characterised relations among the later Meers certainly facilitated what Sarah Ansari has called the 'peripheral imperialism, ${ }^{58}$ of the British in Sindh, leading eventually to its annexation.

Meanwhile in February 1821 another raid from across the Sindh border occurred in Cutch, and Sadlier was instructed by the Governor of Bombay to demand the surrender of Tahir Loone, the person considered responsible for the attack. ${ }^{59}$ Sadlier realised that the Meers had insufficient resources to curb the Sindhi freebooters, and it proved very difficult to get the Meers to take action against them. On one occasion, while he was leaving the Hyderabad court, a crowd of people stoned his party. Many of the Meers' subjects were Baluchis, and members of this community could well have been the ringleaders of anti-British action; as we will see in Chapter 6, the Baluchi land-holders tended to be strongly opposed to the growth of British power in Sindh. ${ }^{60}$ The Meers apologised to Sadlier for the stone-throwing, but it happened again the next day. The British, however, had allies in Sindh. The help they received from the Bania merchants will be discussed in Chapter 6 .

Letter from Simson, Secretary with the Governor to Sadlier, $8^{\text {th }}$ February 1821 , no. 113,60 , Political Consultations, 7 April 1821, no. 2A, NAI.

Letter from Simson, Secretary with the Governor to Sadlier, $8^{\text {th }}$ February 1821, No. 113, 60, Political Consultations, 7 April 1821, no. 2A, NAI. Mirza Kalich Fredunbeg, A History of Sind, V. II, (Karachi: Scinde Classics, 1902), 212. See chapter 3of the thesis.

Sarah F. D. Ansari, Sufi Saints and State Power: The Pirs of Sindh 1843-1947, (Cambridge: Cambridge University Press, 1992), 1.

Report to Sadlier, 23 January 1821, Political Consultations, 7 April 1821, no. 2A, 54-55, NAI.

From Sir John Keane to the Governor-General, 1 February 1839, Number 148, Correspondence Relative to Sinde: 1836-1843, (London: J.L. Cox and Sons, 1843), 171. 
In his negotiations with the Meers, it became apparent to Sadlier that the Meers were planning to renege on their promise to pay recompense for British losses to Sindhi raiders. He strongly insisted that the payment be made; in the end, however, the Meers paid compensation that was only half the value of the stolen property. The Meers signed a treaty with Sadlier on 5 February 1821. It declared the establishment of perpetual friendship between the British and Meer Kareem Ali and Meer Murad Ali. It provided for the exchange of agents between the two parties, and required that the Meers decline requests from any other European power or Americans to take up residence in Sindh. Residents were subject to local law, and lawbreakers would be tried by authorities in their place of residence. And the treaty required the Meers to take action against the Khosas tribe and any other Sindhis who made raids into British territory. ${ }^{61}$

Sadlier left Sindh on 20 February $1821 .^{62}$ During his return journey, he made several stopovers, delaying his return to Mandavee. These stopovers fuelled rumours about a British invasion of Sindh and attracted the attention of the Meers. The mission, however, reached Mandavee on 26 March without incident. ${ }^{63}$ Until 1821 the British were primarily interested in protecting its cotton trade in Cutch against the raiders from Sindh. That was the main purpose of their negotiations with the Hyderabad Meers in 1821. Because the Meers promised to deal with the raiders, the annexation of Sindh was no longer considered necessary.

\section{The British, Sindh and Sindh's neighbours}

All engagements between the British and Sindh before Sadlier's visit to Sindh in 1820 lacked cordiality. The Meers' distrust of the British was manifest in the cool reception Sadlier received in 1820 . And the 1821 treaty did not make a big difference at first. Cross-border forays into Cutch continued. The Meers were well Political Consultations, 5 May 1821, no. 3, 71-72, NAI.

63 Sadlier to the Hon'ble Governor of Bombay, 2 March 1821, Political Department, 18201821, Vol. 46, no. 56, MSA. 
aware of the military superiority of the British; they refrained from directly challenging them in Cutch, but remained highly suspicious of British intentions. The British, for their part, suspected the Meers of giving protection to the Meena tribesmen who plundered Cutch in 1825, and again created the threat of a BritishSindh war. After victory in the Anglo-Burma war of 1824 - 26, British forces were free to deal with the maraudings of the Meena tribe in the north-west of their empire in India. ${ }^{64}$

Within this context the story of Alexander Burnes becomes significant. It is recounted in the two-volume collection of biographies published in 1867 by historian John William Kaye. Alexander Burnes was transferred to Cutch in 1825 to serve as an army lieutenant there. He anticipated a war with Sindh and, when the British authorities began to prepare for an attack on Sindh in July 1825, he hoped that he might be appointed to lead the military campaign. Burnes was not appointed campaign leader, but he did secure the position of Persian interpreter in the army of eight thousand soldiers that was to march into Sindh. The campaign was, in the end, abandoned, but Alexander Burnes' hopes for promotion were realised when authorities recognised the value of the survey and mapping work he had done. He was appointed in the department of Quartermaster-General and then in 1828 he was made Assistant Quartermaster-General. After his transfer to Bombay he met John Malcolm, the Governor of Bombay and volunteered to survey the river Indus. His mission to Sindh will be discussed in the next section; first we should consider why the British authorities decided not to proceed with the military operation against Sindh in $1825 .^{65}$

Kaye does not indicate why the military campaign was dropped in 1825 , but a possible reason is that the British still did not have adequate knowledge of pathways, transport routes and the complex geography of the region. And the Indus had not yet been surveyed. In the event of a British attack, the Sindhi's local knowledge of terrains and hideaways gave them an advantage. Another factor is that Military Services of India, V. II, (London: A. Strahan and Co., 1867), 14-15. Ibid., 16.
} 
the British still did not have a foothold in the Sindh court and had no influence over any of the Meers. At this stage, therefore, a military action to subdue or annex Sindh would have been premature.

The Company's forward policy that targeted north-west India was not yet in place. Even so, there was a growing confidence within British circles that, the victory against Burma (1826) and the conquest of Bharatpur in 1827 had given the Meers an awesome demonstration of British strength. Furthermore, to counter the Russians, who had now entered Persia, the Meers were again looking to ally with the British. The enemy from whom the Meers had most to fear, however, was Ranjit Singh of the Punjab. ${ }^{66}$ After conquering Multan in 1818, Ranjit coveted territories to the south of Multan. ${ }^{67}$

The growing conflict between Ranjit Singh and the Hyderabad Meers, and British intervention in the conflict, has been outlined in Chapter $4 .{ }^{68}$ Ranjit even attempted, unsuccessfully, to force the Meers to pay to the Punjab state the tribute they owed to Afghanistan to the Punjab state. He did not press the matter because he had to turn his attention to an uprising led by Sayyid Ahmed, who had declared jihad (religious war) against the Sikhs in Peshawar. ${ }^{69}$ Kushwant Singh contends that the British encouraged Sayyid Ahmed's movement and allowed many Muslims from as far north as Allahabad to join it. ${ }^{70}$ It could be that the British gave this encouragement in order to prevent Ranjit Singh from expanding further and thereby remove a threat close to the border of British India. This is an example of the Company's strategy of playing one Indian power against another, a strategy that became prevalent in the early nineteenth century.

In Upper Sindh at this time, Sufi Pir Rashid Muhammad's son, Pir Pagaro, had emerged as a powerbroker with an immense following. Parveen Talpur tells us

C.L. Mariwala, 'Commercial Navigation of the Indus: 1820-1832 A.D.', in Mubarak Ali ed. Sindh Observed (Lahore: Gautam Publisher, 1993), 103.

Ibid.

See chapter 4 of the thesis. Parveen Talpur, Talpur Rule in Sindh, (Lahore: Ferozsons, 2002), 56. Khushwant Singh, Ranjit Singh:Maharajah of the Punjab, (London: George Allen \& Unwin Ltd), 1962), 162-165. 
that Sayyid Ahmed invited Pir Pagaro to join his movement, and the Pir then gave the name Hurriyat (freedom) to Sayyid Ahmed's movement. Sayyid Ahmed also invited the Hyderabad Meer, Karam Ali, to join Hurriyat. Karam Ali declined the invitation, even though he was sympathetic to Sayyid Ahmed. ${ }^{71}$ Khushwant Singh says that Sayyid Ahmed's movement began to decline once followers from the Pathan tribes began to leave and he was left to fight the Akalis (Sihks) without many armed followers. In May 1831 Sayyid Ahmed was killed fighting the Akalis. The new ruler of Kabul, Dost Muhammad, took on leadership of the movement, so it did not die ${ }^{72}$ But Dost Muhammad's rule was unstable and not strong enough to restrain Ranjit Singh. Sayyid Ahmed's movement, therefore, failed in the end, to halt Ranjit Singh's progress. Ranjit had emerged as a serious obstacle to the consolidation of British interests in Sindh. Given this situation, it is not surprising that the Meers of Hyderabad wanted the friendship of the British in the late 1820s.

\section{James Burnes' Mission to Sindh}

After Sadlier's mission and the British decision of not to go to war with Sindh, the relationship was, for a while, less strained. In fact, it was cordial to the extent that on October 1827, Meer Karim Ali asked the Company to send a doctor to treat his brother Meer Murad Ali who was afflicted with an unspecified illness and could not be helped by local doctors. Elphinstone decided to send Dr James Burnes, older brother of Alaxender Burnes, ${ }^{73}$ to Hyderabad. Burnes' written account of his experience at the Sindh court was published in 1829, and it serves as a valuable source of information for the period of our study. ${ }^{74}$ In the following section we discuss Burnes' 1827 visit to Hyderabad, how it changed British attitudes to Sindh, and the evidence in Burnes' account of Sindh's political and strategic vulnerability to the increasingly powerful British in the 1820s.

Talpur, Talpur Rule in Sindh, 55.

Singh, Ranjit Singh, 165.

Kaye, Lives of Indian Officers, 5

James Burnes, A Visit to the Court of Sindh by James Burnes with an introduction by Hamida Khurro (Karachi: Oxford University Press, 1974), first published by the Summachar Press, Bombay, in 1829. 
Burnes said that he always wanted to explore India's north-west frontier; the region offered him the opportunity of a great adventure. He set out for Sindh on 25 October 1827; he was accompanied by native infantrymen from the brigade in Bhuj as well as troopers and horsemen from the Chief (Rao) of Cutch's army. Gopaldas, an agent from Sindh, served as his attendant; Gopaldas was a trusted employee of the Meers who had previously been assigned in Kabul to watch over the chief minister there. ${ }^{75}$ Burnes realised that the Meers were suspicious of him; Gopaldas had been instructed to take note of his activities and prevent him from learning much about Sindh. James Burnes' mission arrived at Lackput on 28 October. Gopaldas stopped him from going further until a fresh permission to proceed arrived from Hyderabad. Burnes was unhappy about this, most particularly because he was travelling to Hyderabad at the invitation of the Meers. ${ }^{76}$

Burnes used his time at Lackput to write down his observations of the place. It was a small town, situated in western Cutch and featured a large fort. He saw no agricultural land on the town's outskirts. He noted that the mountains and their foothills close to Lackput were home to the 'plundering tribes' responsible for raids on Cutch. ${ }^{77}$ On 3 November, another letter of invitation arrived from the Hyderabad Meers, and Burnes was now able to continue his journey. He wanted to travel to Hyderabad through the regions of Pallia and Gharee, but Gopaldas suggested that they should take the route through Jatee, a province close to Lackput. Burnes, much perplexed by Gopaldas' change to the planned route, later realised that it was to give the Meers enough time to prepare an appropriate welcome when Burnes arrived at court.

After crossing the stream that passed through Lackput, Burnes' party reached a kotree (landing place) in the Runn region (a seasonal saltwater marsh). Burnes found it to be a desolate place, with no sign of habitation. After walking for a few hours in a north-westerly direction, they reached Lah, also located in the Runn and featuring only a few shrubs and bushes. Here, however, Burnes did see a few people 
collecting tolls on goods carried by merchants, and he noted that they were different from the men of Cutch in appearance and dress. ${ }^{78}$ Burnes' detailed notes on local geography and ethnographical data about the tribal people of Sindh provided information that British authorities could use when dealing with the marauding Meena and Luna tribesmen who disrupted trade in the region.

The route to Hyderabad on which Gopadas had insisted took the travellers through regions that were free of lawless tribes. On 5 November they reached a place called Ruree. Burnes noted that the region between Ruree and the kotree at Lah was marshy desert. It was not a place from which an army could be recruited, nor was it a place through which an invading army from Cutch or the south-east could easily advance. Waiting for Burnes at Ruree were officials sent by the Meers to welcome him: Laghree, the governor of Jatte, and Bahadur Khan. From Ruree the mission passed through Shahpur, Meerpur, Laiqpur and Bunna before reaching Hyderabad on 10 November. When at Hyderabad, Burnes received a warm welcome and was treated with 'kindness' and 'respect' by the Meers. He described the Hyderabad royal court as simple and elegant. ${ }^{79}$

Once in Hyderabad, Burnes immediately began to treat the ailing Meer Murad Ali. The Meers were still mistrustful of Burnes but, given the failure of native doctors, they had no choice but to let the foreign doctor try to heal Murad Ali. It seems that Meer Murad Ali's disease was hereditary, because his brothers Meer Fateh Ali and Meer Ghulam Ali had suffered similar symptoms before they died. Burnes did not leave a written record of his diagnosis, only that within ten days of treatment Meer Murad Ali showed signs of improvement. By January 1828, Murad Ali was judged to be completely cured ${ }^{80}$ Burnes' success greatly helped to lift the Meers'confidence in the British, He had stayed in Sindh for almost three months; he left on 21 January and arrived back in Cutch on the 28th. ${ }^{81}$ While living at Sindh

Ibid., 28-32.

Ibid., 34-38.

Ibid., 53-54.

Mariwala, 'Commercial navigation of Indus', 106. 
court, in close contact with the Meers, he had gained some rare insights into Sindh politics that could be used by the Company to advance its forward policy in India.

In his account of Sindh's political system, Burnes made an assessment of the relative power of the different Meers. As we have seen, a special feature of the Talpur regime at the time of its founding in 1783 was that political power was shared by four brothers (the 'four friends'). Burnes, after his close encounter with the Meers, found that there was still the appearance of power sharing in 1827. In reality, however, he found Meer Murad Ali to be all-powerful, a despot, and the other Meers cooperated in supporting him. Burnes was told that Murad Ali shared power with his brother, Meer Karim Ali, but he judged this to be illusory; Meer Karim Ali was totally subservient to Murad Ali. Burnes did not see evidence of the conflicting interests and divisiveness that had once pertained among the principal Meers, because now junior members of the family accepted the authority of their seniors. Burnes described Meer Murad Ali as 'selfish'and an 'Asiatic Tiberius'. In contrast, Meer Karam Ali as 'cheerful', 'condescending', 'liberal' and 'even affable'. He was kind to his subjects and public opinion was in his favour. ${ }^{82}$

Burnes observed tension and conflict among the Sindhi elite. The relationship of the principal Meers with the Meers of Meerpur (the Mankani family of Meers in south-east Sindh) and of Khairpur (the Sohrabani family of Meers in Upper Sindh) was a feudal one. In the past, Meer Sobdar, whose grandfather had been a principal Meer, had fallen out with his father, Meer Fateh Ali, but he now offered his support to the Hyderabad Meers. Nevertheless, the young man remained unpopular with the principal Meers, and they instructed Burnes not to communicate with him. Meer Sobdar had, in fact, been scheming against the Hyderabad Meers. He had allied with some of his father's friends at Hyderabad and, in collusion with Meer Ali Murad, the son of Meer Thara (ruler of Meerpur), he plotted a coup against the principal Meers; 
he wanted to seize back what he regarded as his birth right, the rulership of Sindh. Burnes' visit to Hyderabad interrupted these schemings. ${ }^{83}$

Within five days of Burnes' departure from Hyderabad, Meer Sobdar went to Islamkot (in the Tharparker region in Sindh's south-east), and began recruiting soldiers willing to unseat Sindh's rulers. Soon he was able to lead 15,000 soldiers on a march to Hyderabad. The Hyderabad Meers, however, were not prepared to engage in an armed conflict and reached a compromise with the young rebel. Meer Sobdar was given some land and allowed a place in government. In this way the feudal relationship between Meer Sobdar and the Hyderabad Meers was converted into a relationship of power sharing. Meer Thara, another of the Hyderabad Meers' feudal dependants, declared war on Hyderabad several times, but was defeated each time. Meer Thara also gave protection to the Meena tribe which regularly plundered nearby regions. ${ }^{84}$

From this we can see the value of Burnes'1829 account of Sindh for British strategists. It provided the Company with a clearer picture of Sindh's internal politics. It provided information about social hierarchies and, in particular, elite-class structure. It offered an assessment of the strengths of the Meers' power sharing system, and pointed to the inherent weaknesses and tensions embedded in the feudaltribal system.

\section{Sindh and the defence of British India}

We have seen how, in 1827, the Company was close to going to war with Sindh; it was largely a change in international alignments that pulled the British back from war and resulted in a shift in British policy relating to regions north-west of British India, including Sindh. Here we will consider the debate among British officials about the defence of British India; the debate produced two schools of thought in the 1820 s and 1830s - the Bombay and Ludhiana schools.

$\begin{array}{ll}83 & \text { Ibid. } \\ 84 & \text { Ibid., } 63 .\end{array}$ 
The Bombay school, or the 'Malcolmites' (named after John Malcolm), proposed that Persia could be used as a buffer state for the defence of British India. People aligned with the Ludhiana school of thought, also called 'Harfordians'(named after Harford Jones), argued that an alliance with Afghanistan was the best way of preventing an invasion from the north. The Malcolmites disagreed with the Harfordians on the grounds of Afghanistan's weakness; it was a cluster of small principalities that were regularly at war with each other, and Kabul had a hostile relationship with the Sikhs, now well established in the Punjab. An alliance with the Afghans, therefore, could alienate Ranjit Singh, the ruler of Lahore, and result in British India having a powerful enemy on its north-west frontier. Rather than alienating Ranjit Singh, the British would do well to ally with him because that could make the Indus plains a defensive zone from which French advances could be resisted. $^{85}$

This debate had a strong bearing on British policy relating to Sindh. Sindh was still under Afghan hegemony and located in an area of strategic importance to British India. And, as we have seen, it was also coveted by Ranjit Singh. For these reasons Sindh in the 1820s came to be included in the 'great-game' strategy designed by the British to counter Russian expansion. We should note that Sindh became strategically important to the British only in the 1820s; as Edward Ingram points out, British concern about Russian ambitions in central Asia and the threat it posed to British India started well before $1828 .{ }^{86}$

Charles Metcalfe and Lord William Bentinck (who served as GovernorGeneral of India from 1828 to 1835) both belonged to the Ludhiana school and opposed the Persian mission. Until 1828, Persia was the ally on which Britain could depend to defend its interests in the Middle East and India. The 1828 Treaty of Turkmanchay that concluded the Russo-Persian war changed the power balance in the region north-west of British India. Persia ceded to Russia most of the Khanates it had held in the Caucasus, and it was forced to accept commercial treaties with 
Russia on Russian terms. When the Whig government under Earl Grey (1830-1834) came to power in Britain it transferred responsibility for the British mission to Persia from the Foreign Office in London to the Government of India under Bentinck.

Under Bentinck the British mission to Persia was withdrawn, and the defensive zone against invasion of British territory from the north was now to be located in Afghanistan. These developments put the Malcomites on the back foot. And, as Edward Ingram points out, so did the ascendancy of Whigs in the British parliament; the Malcomites were closely associated with the ultra-Tories. ${ }^{87}$ For our purposes, what is important is that when the focus of Britain's Middle East policy shifted from Persia to Afghanistan, Sindh, as one of Afghanistan's tributary states, became more important to the British.

Lord Bentinck's immediate concern was to deal with the financial difficulties that were directly related to the Company's military engagements on the subcontinent. But he had a broader agenda. Bentinck, a Utilitarian, dreamt of a modern and unified India; other British officers such as Thomas Munro and Lord Elphinstone believed that the British should govern India in ways that accorded with Indian customs and cultural norms. Bentinck on the other hand introduced reforms such as the use of English in schools and the creation of a class of Indians who were loyal to British India and who could staff the British public service in India. ${ }^{88} \mathrm{John}$ Rosselli has called Bentinck a 'liberal imperialist'.

Bentinck also realised that the passive policy of watchfulness employed by his predecessor in relation to Sindh and Afghanistan had not effectively dealt with the threat from the west, and he proposed instead a forward policy in the regions of the Indus. ${ }^{90}$ This required first gathering intelligence about these regions.

Accordingly, Bentinck sent missions that aimed to learn about the political situation in Sindh and opening up the Indus as a British trade route in Sindh.

Ibid., 200.

Ibid., 213-215.

John Rosselli, Lord William Bentinck: the Making of a Liberal Imperialist: 1774-1839

(Berkeley and Los Angeles: University of California Press, 1974), 324.

Mariwalla, 'Commercial Navigation of the Indus,' 101. 


\section{The Indus Survey}

The British adventurer William Moorcroft in 1809 wrote about the importance of the river Indus for commerce in the regions through which it passed. ${ }^{91}$ John Malcolm, Governor of Bombay from 1827 to 1830 , was more interested in the river's strategic role; he wanted to ensure that the Indus could be navigated by British forces sent to the north-west for the purpose of resisting advances by enemy forces into British territory. Malcolm even proposed the annexation of Sindh in 1828, but Metcalfe, a prominent member of the council of the Governor-General, did not agree. Malcolm, as Michael Fischer says, believed that British expansion in India and the annexations of territory were 'just' and 'inevitable'. ${ }^{92}$ Metcalfe, on the other hand, was committed to the 'law of nations' principle, and considered that the annexation of Sindh would violate that principle. In his view, the advance of Russia was of greater concern for Sindh than for British India. ${ }^{93}$ In any case, a Russian threat was remote, in his view; he suggested a continuation of the strategy of keeping a close watch on, but not interfering in, what was happening in north-west India. In the meantime, the rulers of states between Persia and British India should be placated rather than antagonised. The Governor-General endorsed Metcalfe's position, judging it to be pragmatic; the idea of annexation, therefore, was put aside for the time being. Instead, there was to be a commercial push into Sindh, and plans were put in place for surveying the Indus, without antagonising Sindh's rulers.

The survey of Indus was a pre-requisite for the implementation of any forward policy in Sindh that would strengthen the security of British India's northwest frontier. Only the section between Thatta and Hyderabad had ever before been surveyed by a European, and no army could sail up the Indus to counter an invasion from the north-west without a thorough knowledge of the river's course and navigability. But the Indus could only be surveyed by deceiving the Meers of Sindh. The plan was to get the Meers' permission for British envoys to sail up the Indus to

G. S. Chhabra, Advance Study in the History of Modern India (Volume-2: 1803-1920) (New Delhi: Lotus Press, 2005).

Mariwala, 'Commercial Navigation of the Indus'107. Ibid., 107. 
Lahore in order to deliver gifts to Ranjit Singh. Metcalfe greatly disliked the planned deception; he considered it to be ...

... unworthy of our Government... . [I]t is just such a trick as we are often falsely suspected and accused of by the Native powers of India... .It must be remembered that the survey of the Indus or any part of Sindh country may give us the power to injure that state, may even assist in conquering it and in the course of events is as likely to be turned to use for that purpose or any other. $^{94}$

Bentinck, however, decided to proceed with the plan and here we need to return to the story of Alexander Burnes. He was put at the head of a mission to Lahore with instructions to explore the Sindh region as he travelled. As well as surveying the Indus, he was also to meet the Meers at Hyderabad and Khairpur. This was to be the first British mission to Khairpur. ${ }^{95}$

Alexander Burnes left Cutch for Sindh on 20 January 1831. He travelled with three companions-J. D. Leckie, a surgeon and a surveyor. They reached the easternmost point of the Indus, a place called Koree, on 24 January and, without attracting local attention, surveyed the Indus for the next four days; they reached Pittee, its westernmost point, on the 28th. After surveying Indus for some thirty miles upriver from the sea, Burnes informed Sindh officials of his arrival. The Meers' officials did everything they could to stop the party from proceeding further until permission from the Meers was received. ${ }^{96}$

Unable to proceed further, Burnes had no option but to return to the coastal port where the river journey had begun. When permission from the Meers arrived, Burnes' party began their Indus voyage again; it was now 10 February. The Meers were still fearful of a British attack. In order to halt the expedition, the officials now attempted to starve Burnes and his companions. When Ranjit Singh learned that gifts from the British meant for him were stuck in Sindh because the Meers would not let

$94 \quad$ Metcalfe's minute, October 1830, in Kaye, Lives of Indian Officers, 18.

$95 \quad$ Kaye, Lives of Indian Officers, 16.

96 Mariwalla, 'Commercial Navigation of the Indus', 109-110. 
Burnes' party sail up the Indus, he ordered Commander Ventura, an Italian soldier in his service and based near Bahawalpur, to march to Dera Gazi Khan close to the Sindh border. The news that Ranjit Singh's army was on the march and close to Shikarpur, caused the Meers to capitulate; Burnes was allowed to travel to Lahore by sailing up the Indus. ${ }^{97}$

On 10 March Burnes' party resumed the journey and on 12 April reached Hyderabad. There the group was cordially welcomed and, after the formal exchange of presents and compliments, continued on upriver. Meer Murad Ali did not want Burnes to meet with Meer Rustam in Khairpur, because the Hyderabad and the Khairpur Meers were in competition for a closer relationship with the British. On 15 May, however, Burnes did make a stop at Bukkur in Khairpur. The Khairpur Prime Minister, Muhammad Khan Ghori, received Burnes and conveyed to him Meer Rustum's desire for a Khairpur alliance with the British on the same footing as the alliances with Bikaner, Jaisalmer or Bahawalpur. ${ }^{98}$ Burnes promised to pass on the Meer's message to his superiors in Bombay. He left Bukkur on 21 May and reached Lahore on 17 July. $^{99}$

The travellers stayed in Lahore until 14 August 1831. After they returned to Cutch, Burnes went to Shimla to give the Governor-General an account of the expedition. At his meeting with Bentinck, Burnes proposed a more ambitious expedition that would be routed through the Indian Caucasus, Bulkh, Bukhara, Samarkand, Aral, the Caspian Sea and Persia. The opportunity for this journey came when the British were preparing to deal with threats from Russia in early 1832. On 23 September 1831, Burnes wrote to his sister: 'The Home Government have got frightened at the design of Russia and desired that some intelligent officer should be sent to acquire information in the countries bordering on the Oxus and Caspian'. ${ }^{100}$ Burnes volunteered for the mission and Bentinck was very pleased to appoint him to

\footnotetext{
$97 \quad$ Ibid., 111.

98 Letter from Burnes to Princep, $20^{\text {th }}$ September 1831, Political Consultations, Vol.76/519, MSA.

99 Mariwala, 'Commercial Navigation of Indus', 113.

$100 \quad$ Kaye, Lives of Indian Officers, 20.
} 
lead it. On 1 January 1832, Burnes set off for Astracan in southern Russia to spy on the activities of the Russians; the expedition travelled by way of Lahore, Kabul, Bamiyan, Bulk, Bukhara and Caspian Sea. ${ }^{101}$

When reporting on the expedition to Bentinck, Burnes drew on his exploratory work to make recommendations about British policy relating to the regions he had visited. And then he went to London to report his findings to the authorities there. On 6 November 1833 he met William IV of England, who was very interested to know about his travels and, specifically, Russia's intentions, ambitions, treaties with other nations and its ambassadors. ${ }^{102}$ Clearly a 'Russophobia' had become prevalent in England. ${ }^{103}$ As we have seen, fear of a Russian invasion of British India had made Sindh a strategically important place for British authorities in Bombay and Calcutta.

By the early 1830s the British had developed commercial interests in the region beyond the Indus and Kabul. As well as being important strategically, the region provided new markets for British manufactured goods. And so the Company now began to give serious attention to the problem of getting merchandise into the northwest frontier regions and central Asia. And, of course, the navigation of the Indus was vital to this purpose. The region to the east of the Indus did not promise markets for English goods because it was well supplied with goods from the Punjab. The British could anticipate selling heavy materials such as copper, tin and brass to the Punjab, but there was little demand for British cotton, chintz, calicos, muslin or woollens in the region beyond the Indus. ${ }^{104}$

Kabul had once been supplied with many of these fabrics from Russia. From about 1816 there was a market shift in favour of British goods, beginning with the arrival of chintz fabric imports and followed by a growing supply of goods

\footnotetext{
$101 \quad$ Ibid.

102 Ibid., 26-27.

103 Russophobia gained prominence after the treaty of Turkmanchay between Persia and Russia in 1828; see page, Ibid., 30.

104 Memorandum drawn up by the Governor- General on the subject of our Relations on and Beyond the Indus by Lieutenant Alexander Burnes, Calcutta, 18 May 1833, Foreign Department, 6 June 1833, no. 8, NAI.
} 
manufactured in British India. Alexander Burnes spoke of a 'commercial revolution' in Kabul at this time; he was referring to the growth of British trade in the Afghan capital and the increase in the demand for fabrics manufactured in England. English products that were traded in regions west of the Indus were shipped from England to Bombay or Calcutta. The Afghan merchants travelled to Bombay to purchase these goods, and they transported them to Qandahar, Kabul and Ghazni along the difficult land routes from Bikaneer and Sindh. English goods shipped to Calcutta reached Ghazni, Kabul and Qandahar through Delhi, then Bahawalpur and Multan; they crossed the Indus at Multan and reached Kabul through the Golairee pass. But Ranjit Singh's push south-westward had led to the closure of the caravan trade routes from Delhi to Lahore and Attock. British goods, therefore, were carried eastwards from Kabul to Peshawar and Attock near the Indus. ${ }^{105}$ River Indus would have been a mucg easier route for this merchandise.

Ranjit Singh after conquering regions west of the Indus, came close to the northern border of Khairpur in 1831 and was intending to occupy the city. ${ }^{106}$ This drove the Khairpur Meer to seek direct relations with the British. In early 1831, the British had decided to send a mission to Hyderabad, Khairpur, Bahawalpur and the Punjab to pressure the rulers of these places to agree to open the river Indus to British trade; they also wanted tolls on merchandise carried on the river to be fixed and uniform, and they wanted effective protection of merchant ships that sailed the river. Captain Wade was appointed to submit this demand to Ranjit Singh. He left on 13 January 1831 and remained in the Punjab until 12 March. After his return to Ludhiana on 29 March, Governor-General Bentinck received two letters from Ranjit Singh expressing the Punjab ruler's faith in the British and his willingness to open the Indus to British trade. In turn, Bentinck promised Ranjit Singh that he would

\footnotetext{
105 Ibid.

106 Letter from W.B. Bentinck, Foreign Secret Letter to Court, 27 Feb- 19 December 1834, no. 135, NAI, Grewal, The New Cambridge History of India, The Sikhs of the Punjab: Eastern India 1740-1828.
} 
receive military and financial assistance from the British if he was willing to help resist an invasion of British India by any European power. ${ }^{107}$

Captain Wade made a similar mission to Bahawalpur. The rulers of the Punjab, Bahawalpur and Khairpur were more willing to meet British demands than were the Hyderabad Meers. Also, instability in Afghanistan and the expansionist ambitions of European worried the British more than they worried Sindh's rulers. And what the British were learning about the situation on India's north-western frontier and central Asia really alarmed them. They had sent to Qandahar an akbarnavees (news reporter) who could keep them informed of what was happening there. By 1832 Burnes had returned from Kabul and had reported what he had observed to William Bentinck. From various sources, then, the British learned that the Persians were planning to conquer Khorasan and Kashmir with the help of Russia; they had an army of 30,000 Persian and 3,000 Russian soldiers. The boundary between British India and the Punjab was the river Sutluj; this was fixed by an 1809 treaty with Ranjit Singh. The river reached into Kashmir, which Ranjit Singh had annexed. Russia and Persia, therefore, threatened both the British and Ranjit Singh and, for the British, the strategic importance of Sindh was further highlighted. It could serve as a base from which to deal with the competing powers in north-western India and central Asia. In early 1832, the Calcutta authorities decided that a British army was to sail up the Indus and that British residents be established at Hyderabad, Thatta, and Shikarpur. An envoy was also to be sent to Khairpur. ${ }^{108}$ In the section that follows, we will examine the British relationship with Sindh as it developed after Burnes' 1831 survey of the Indus river. ${ }^{109}$ Letter From W. B. Bentinck, 19 November, 1831, Foreign Secret Letter to Court, $27^{\text {th }}$ Feb 1829 - 19 December 1834, no. 135, NAI. Translation of a letter from the native agent in Sindh to Colonel H. Pottinger, Hyderabad, 15 January 1832. Foreign Department Secret Consultation, 2 April 1832, no. 8, 9-10, NAI. Alexander Burnes, "Travels into Bokhara; Being the Account of a Journey from India to Cabool, Tartary and Persia; Also, Narrative of a Voyage on the Indus, from the Sea to Lahore, with Presents from the King of Great Britain; Performed under the Orders of the Supreme Government of India, in the Years 1831, 1832, and 1833 : Burnes, Alexander, Sir, 1805-1841 : Free Download \& Streaming,” Internet Archive, accessed April 8, 2015, https://archive.org/details/travelsintobokha03burn.
} 


\section{Opening the Indus to British trade}

Alexander Burne's mission to southern Russia and Kabul in 1832 took him away from his work on the Indus river. But in Bombay and Calcutta, interest in Sindh and the Indus river's navigability continued to grow. Following Burnes' 1831 expedition, Lord Bentinck asked Lord Clare, the Governor of Bombay, to send a mission to Sindh for the purpose of opening the Indus to British trade. A mission led by Lieutenant Colonel Henry Pottinger left for Hyderabad in December 1831. It left Bombay on 4 December and reached Mandavee on 7 December. From Mandavee the mission travelled overland to Hyderabad. On 10 December Pottinger sent a letter to Meer Murad Ali of Hyderabad announcing the arrival of his mission. ${ }^{110}$

Murad Ali had heard that a British mission was on its way, and that it would be requesting that the deposed king of Afghanistan, Shah Shuja, be given safe passage through Sindh. Furthermore, he was told that Pottinger had come to Sindh with seven boats, and this made him suspect that the British intended to seize Shikarpur. ${ }^{111}$ The Meer instructed that if Pottinger's baggage was found to contain military equipment, he was to be asked to return. If the mission was unarmed, it would be allowed to proceed to Hyderabad. ${ }^{112}$ Accordingly, Meer Murad Ali sent an officer to Derajay Bundar to ascertain what the seven boats actually contained. ${ }^{113}$

On arriving at Hyderabad Pottinger sent to Murad Ali a memorandum that made a few requests. First the Englishman sought permission to visit the Meer at any time. Another expressed the wish to meet Meer Rustam of Khairpur; Pottinger asked that he be allowed to write to Meer Rustam and request that he send escorts who could accompany him to Khairpur. The Meer gave his consent to all that was asked except the request to meet with the Khairpur Meer. Murad Ali pointed out that he was Sindh's principal Meer and so all the communication with Khairpur had to be

\footnotetext{
110 Letter from W.B. Bentinck to Secret Committee Foreign Department of the Court of Directors, Secret Committee, 2 July 1832, para 7, NAI.

111 Letter from W.B. Bentinck Foreign Secret Letter to Court, 27 February- 19 December 1834, no., 135, Para17, NAI.

112 Letter from W.B. Bentinck, Foreign Secret Letter to Court, 27 February- 19 December, no. 135, Para 20, NAI.

113 Ibid.
} 
routed through him. Pottinger was advised that Meer Rustam would be coming to Hyderabad for Meer Shahdad's wedding, so he could meet him there. The British mission was also asked to proceed to Hindustan after staying no longer than another fifteen days in Hyderabad. ${ }^{114}$

On 28 January 1832 Meer Murad Ali invited all the prominent chiefs of his court such as Ahmed Khan Lagharee, Muhammad Khan Nizame, Dost Ali Talpur, Muhammad Khan Talpur and many others to be present for Pottinger's visit to the palace. In a report of his visit, Pottinger noted that Meer Murad Ali was seated at the centre of a mixed gathering of people. On his right was his eldest son, Meer Noor Muhammad Khan, whom the Meer had designated as his heir. Meer Sobdar, the young rebel who had been brought to heel in 1828 , was seated next to him. On the left-hand side of the throne were Meer Muhammad Khan, Meer Nasir Khan and Meer Shahdad Khan. The court was so crowded with people that there was no place for Pottinger to sit. People were shouting at each other and making space for themselves by pushing other people aside. Murad Ali offered Pottinger a seat close to him and warmly declared his friendship with Pottinger, the Governor-General and the government of Bombay. ${ }^{115}$ But that morning, before the court reception, Meer Murad Ali had sent a letter to Pottinger through Ahmed Khan Laghree in which he told of his surprise to learn the real purpose of the present British mission: he now knew that it was about the movement of merchants and merchandise on the Indus, the problem of Persia's planned invasion of Khurasan with Russian assistance, and the status of the deposed Afghan king, Shah Shuja, still in exile in the Punjab. ${ }^{116}$

The next day, on 30 January, Pottinger had a private meeting with Meer Murad Ali. Meer Murad Ali acknowledged that a Persian invasion of India would be ruinous to both British India and Sindh. If invasion by a foreign power looked likely, he would contribute 30,000 cavalry and 20,000 infantry to the British army and not ask for payment; or he would provide double the numbers if the British covered the

\footnotetext{
114 Letter from W. Bentinck, Foreign Secret Letter to Court, 27 February -19 December 1834, no. $135,339-345$, NAI.

115 Ibid., $335-337$.

116 Ibid., 337.
} 
costs. However, his troops were not to be sent to a foreign country such as Afghanistan. Given that the Hyderabad Meers had a total force of 80,000 soldiers, of which 60,000 were cavalry, the Meers' offer was quite significant. ${ }^{117}$ With regard to the opening of the Indus to British trade, Meer Murad Ali still refused his consent. This was in spite of Pottinger's repeated request that the Indus be opened in the same way as the harbours of Calcutta and Bombay were open to merchants of all nations, from whom the government collected goods taxes. ${ }^{118}$

The following day Munshi Kushiram, on behalf of Murad Ali, presented to Pottinger a draft treaty consisting of nine articles. It made the predictable statements about friendship between Hyderabad and the British and declared that no foreigners other than the English could enter Sindh. It allowed native merchants, whether they be Muslims, Hindus, Parsees, Jews and so on, to travel and transport merchandise on the Indus, but Englishmen did not have this right. The British were required to guarantee that they would not launch attacks on any other places within Sindh's borders. The treaty also declared that the enemies of the Sindhis would be enemies of the British and vice-versa, and that the English would be provided with a security force of 50,000 men at Sindh's expense; the force was to be stationed within one hundred kos of Hyderabad. The Sindh government undertook to fix regular duties on commercial goods shipped on the Indus. The ninth article required that the British instruct the Kabul Government and Maharaja Ranjit Singh that Sindh had British protection and should be treated as though it were part of British India. ${ }^{119}$

The ninth article suggests that nervousness about the intentions of Ranjit Singh and Kabul was the chief reason why Meer Murad Ali wanted an alliance with the British. But Pottinger was unwilling to accept the draft treaty because it closed the Indus to the British. He also insisted on making a visit to Khairpur despite opposition from the Hyderabad Meers, including Meer Nasir Khan (one of Murad

\footnotetext{
117 Mubarak Ali, Sindh Analysed: McMurdos's \& Delhoste's Account of Sindh, (Lahore: Takhleeqat, 1994), 120. 135, 349-351, NAI.

119 Letter from W. Bentinck, Foreign Secret Letter to Court, 27 February-19 December 1834, no. 135, 331-338, NAI.
} 
Ali's sons). ${ }^{120}$ So Pottinger's mission, at this point seemed to be running into brick walls. Even so, while in Hyderabad, the British envoys got to know more about Sindh, including the internal weaknesses of the Hyderabad polity. In the early 1830s, conflict over the issue of Meer Murad Ali's successor was straining the relationship among the Meers. The Khairpur Meers still acknowledged the supremacy of Hyderabad because, in accordance with Baluchi tribal principles, they shared power and property with their kinsmen in Hyderabad. The British, however, tried to put a wedge between Khairpur and Hyderabad, and the Khairpur Meers themselves wanted a separate alliance with the British. ${ }^{121}$

Dalhousie, the mission's surveyor, recorded several interesting observations about the tribal polity in Hyderabad. He noted that Meer Murad Ali claimed to share power with his three brothers, and relations between the four seemed to be warm and amicable. But Dalhousie watched carefully and could see that the four brothers' sons competed with each other for the Sindh throne. There would be four contenders after Meer Murad Ali's death. One of them was Meer Sobdar who, as we have seen, had a somewhat troubled history. Another was Meer Mohammad, son of Meer Ghulam Ali. And the other two contenders were the sons of Meer Murad Ali- Meer Noor Muhammad and Meer Naseer Khan. ${ }^{122}$ Meer Murad Ali despised Meer Sobdar and Meer Muhammad. ${ }^{123}$ Dalhousie described the Meers at the Hyderabad court as "petty kings', and said that the government in Hyderabad could hardly be called a government. As always, the British were watchful for political weakness and divisions that could be used for British ends

Pottinger was given first-hand evidence of the intrigues at court. Zainul Abeedin, a court official, delivered to him a letter from Meer Nasir Khan, which the young Meer declared himself more favourably disposed towards the British mission than was his father. He also expressed the hope that he would succeed to the throne of Hyderabad and wished that his father was dead. Pottinger considered that any help

\footnotetext{
$120 \quad$ Ibid.

121 Ibid.

$122 \quad$ Ali, Sindh Analysed, 114-117.

123 Ibid., 117.
} 
given to Meer Nasir Khan by the British could mean that the young Meer would do anything he was asked to do by the British. Meer Murad Ali was favouring his eldest son, Meer Noor Muhammad, as his successor, but that choice did not have the support of other members of the Talpur family. The Talpur's power-sharing principles meant that even the wishes of the principal Meer could not prevail unless they were agreed to by other family members. Pottinger also judged that if Meer Murad Ali was willing to cooperate with the British, he would lose support within his family and so he would not get his way when a decision was made about his successor; the Talpur family was likely to support a rival candidate. ${ }^{124}$

Further evidence of the family feud among the Talpurs was brought to light when Meer Noor Muhammad also tried to ingratiate himself with Pottinger in the hope of getting his help to win the Hyderabad throne. And within the Khairpur family too there appeared to be feuding, causing Pottinger to postpone for fifteen days his plan to leave for Khairpur. When he did arrive there, he was cordially received. The Khairpur Meer, Meer Rustam, appeared to be well disposed towards the British, and his repeated overtures encouraged them to consider having a British agent stationed there. The British also coveted Bukkur, a region within Khairpur that had commercial importance. ${ }^{125}$

In discussions with Pottinger, Meer Rustam tried to make it clear that he was not a Hyderabad puppet. He said: 'Meer Murad Ali is our brother and the head of the Talpurs but not our master'. ${ }^{126}$ But because the Talpur family was still tied to Hyderabad, Meer Rustam dithered about the terms of a treaty proposed by Pottinger; predictably the thorniest issue concerned British trade along the Indus. Meer Rustam told Pottinger that his brother, Meer Mubarak, would read the draft treaty and make a decision on this issue. After reading the draft, Meer Mubarak pointed out that Meer Murad Ali of Hyderabad was still the principal Meer and Khairpur remained subject to his authority; whether the British could use the Indus as a trade route, therefore,

Letter from W. Bentinck, Foreign Secret Letter to Court, 27 February-19 December 1834, no. 135, 335-337, NAI.

Ibid., .387.

Ibid., 387. 
depended on what Meer Murad Ali decided. ${ }^{127}$ It was only in 1838 that Meer Rustam dared to enter into a separate alliance with the British; his brothers opposed his independent stand. ${ }^{128}$ The information we have about the conflicts among the Meers comes from a letter written by Bentinck to the Court of Directors in 1834 and, undoubtedly, fuelled the push for intervention.

The ruling houses of Hyderabad and Khairpur shared both power and income. For example, Shikarpur's revenue in 1832 was divided among the Hyderabad and Khairpur Talpur. Out of the total revenue of 5 lakhs of Rupees, Meer Murad Ali took 3 lakhs and the Khairpur Meers took 2 lakhs. ${ }^{129}$

On 4 April 1832 Pottinger finally concluded a treaty with Meer Rustam of Khairpur. It required that neither side would encroach on the other's territories, and that British needed to request permission from the Khairpur Meers to use Sindh's roadways and the Indus river; any permissions would be on the same terms that Meer Murad Ali specified for the Hyderabad region. Clearly, the Khairpur Meers acknowledged Hyderabad as a higher authority. As the Hyderabad treaty did, the Khairpur treaty stipulated that transit tolls be levied on merchandise shipped on the Indus, and that customs officials were not to take more from traders than the amounts fixed by the government. ${ }^{130}$

The Khairpur chiefs were not willing to allow British traders to transport goods on the Indus; obviously the matter could only be decided by Meer Murad Ali in Hyderabad. Pottinger arrived back in Hyderabad on 16 April and finally, on 20 April 1832, signed with Meer Murad Ali a treaty consisting of seven articles. Like previous treaties (in, for example, 1809) and the draft treaty given to Pottinger on 31 January, it required that neither side encroach on each other's territory and provided for the occasional exchange of envoys. The important new content related to foreign

Letter from W. Bentinck, Foreign Secret Letter to Court, 27 February-19 December 1834, no. 135, 387-389, NAI.

Sani Hussain Panhwar, Treaties, Agreements, Grants, Engagements and Sanads between the British and Sindh Government; 1758-1842, www.panhwar.com.

Ali, Sindh Analysed, 121.

Ibid. 
trade. The treaty said that, on application, permission would be given to British traders to transport merchandise from British India up the Indus and along roadways in Sindh, but no armed vessels or boats carrying military equipment could use the river. British merchants were permitted to enter Sindh, but must leave after selling and purchasing goods; they could not settle in Sindh. ${ }^{131}$ British merchants would be required to carry passports issued by the British government, and the Meer of Hyderabad was to be advised each time a passport was issued. The duties and levies on the merchandise carried on Sindh's transport routes were fixed by the government, and there could be no changes. ${ }^{132}$

A supplementary treaty was signed two days later. It fixed the tolls and duties to be paid to the two governments on commercial goods. It required that the Meer of Hyderabad draw up a list of duties payable on all kinds of merchandise. These would become operational once approved by the British government; if the British side judged the duties to be too high, Colonel Pottinger would ask Meer Murad Ali to make adjustments. There was also a requirement that the British, Sindh and Jodhpur governments punish plunderers active in the Parkar and Thar regions. Finally, now that Pottinger had reached agreement with Hyderabad on the issue of British access to the Indus, Meer Murad Ali was to send to Meer Rustam a copy of the 20 April Hyderabad treaty so that he could adjust the Khairpur treaty agreed to on 4 April. ${ }^{133}$

Meer Murad Ali doubted that his successors would honour the 1832 treaty that he had signed with Pottinger. He also regretted his decision to allow Shah Shuja to reside in Shikarpur. ${ }^{134}$ Meer Murad Ali's concerns were justified, because his concessions to the British and to Shah Shuja paved the way for the loss of Hyderabad's independence in 1843. After Meer Murad Ali's death in 1833, Shah Shuja took possession of Shikarpur. The four rulers of Sindh were now Murad Ali's two sons, Meer Noor Muhammed and Meer Nasir Khan and their cousins Meer Muhammed and Meer Sobdar. With a large army the Hyderabad Meers launched a

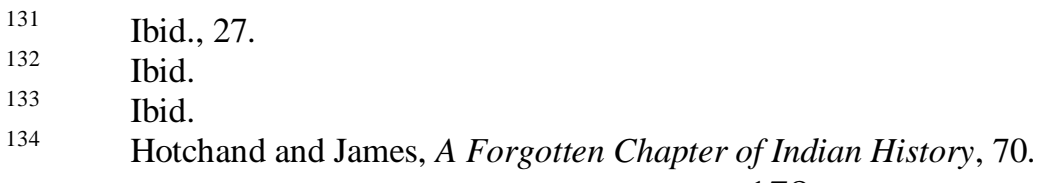


full-scale attack on Shah Shuja's stronghold. A battle at Sukkur resulted in the defeat of the Talpur Meers. ${ }^{135}$

Pottinger's mission in 1831-32 was an important step in the British path to power in Sindh. Christopher Bayly has analysed British interventions in the power struggles that developed in India after the decline of the Mughals. In his view, the British became involved in local politics on Indian terms rather than primarily on British terms. He argues that in the power games that played out in different ways in different places, the British built their power in regional capitals and relied on middlemen to win power. ${ }^{136}$ Michael H. Fischer's work shows that in regions such as Bengal, Carnatic, Hyderabad, Malabar and Awadh, the British officers who established themselves as power brokers in local politics, worked at enriching themselves through questionable fiscal transactions with the rulers of these states. ${ }^{137}$ The Company was able to rise in states such as Bengal by means of financial dealing and scheming with local potentates. ${ }^{138}$ These processes are observable in Sindh. The corporate, tribal nature of the Hyderabad polity and the internecine conflict within the ruling family provided the British with opportunities and justification for increasingly stronger interventions.

The need to defend British India against possible incursions from the Middle East and also internal disunity among the Hyderabad Meers drew the British into a deeper involvement in Sindh politics after the 1820s. So did the lure of profits to be gained from trade along the river Indus. In this respect, it is worth noting the explanation offered by P. J. Cain and Antony G. Hopkins of the reason why the British strove to deepen their involvement in Sindh in the 1830s. They make the point that it was pressure from London merchants for free trade that resulted in the East India Company losing its trade monopoly in India; the Charter Act of 1813

\footnotetext{
135 Ibid., 71.

136 C.A. Bayly, 'The British Military-Fiscal State and Indigenous Resistance. India 1750-1820' in L. Stone ed. An Imperial State at War. Britain from 1689 to 1815 (London: Routledge, 1994), 322-354. Michael H. Fischer, The Politics of the British Annexation of India 1757-1857, (Delhi: Oxford University Press, 1993), 95. Ibid., 65 .
} 
ended the Company's commercial monopoly and made the Crown the sovereign power in India. In the 1820s, Lord Liverpool worked towards further reducing the Company's commercial dominance, and in 1833 the Company also lost its monopoly in the China trade. To meet the consequent loss of revenue, the Company moved into Sindh and the Punjab in the 1830s and 1840s. ${ }^{139}$ For Cain and Hopkins, therefore, an economic imperative was behind British expansion in India's northern frontier regions. However, as we have noted already and will further discuss below, while economic motives were certainly there, these were interwined with strong political interests that impelled the British into Sindh.

In the treaties secured with the Talpur Meers after 1832, the British tightened their commercial and political grip on Sindh. First, Pottinger, on the GovernorGeneral's instructions, persuaded the Meers to allow a British Resident to be based in Sindh; from the British point of view, this was needed to ensure that trade along the Indus was not impeded by local merchants. Meer Noor Mohammad Khan resisted the idea, ${ }^{140}$ but in 1834 agreed to a compromise. The commercial treaty that he signed with Pottinger on 30 October 1834 allowed the British to appoint a Resident whose duty it would be to prevent and settle disputes among traders. The Resident would be under Pottinger's authority, but was to be a non-European. $\mathrm{He}$ could not engage in trade or get involved in anything related to Sindh state affairs. If the need arose, the Governor-General's agent for Sindh could depute his assistant from Bhuj to sort out issues, if any. The agent was then to return to Bhuj.

The 1834 treaty required that a toll of 19 Thatta Ruppes be collected from each boat passing between Ropar and the sea; the revenue from this tax would be shared among the Hyderabad and Khairpur Meers as well as the rulers of other Indian states through which the Indus flowed, namely Bahawalpur Khan, Ranjit Singh and the East India Company. At the mouth of the Indus river in Sindh, where cargoes were moved from sea vessels to river boats, a toll of Thatta Rupees 240 was

\footnotetext{
139 P. J. Cain and Antony G. Hopkins, British Imperialism: 1688-2000, $3^{\text {rd }}$ ed. (New York: Routledge, 2013), 282.

$140 \quad$ Huttenback, British Political Relations with Sindh, 28.
} 
to be levied on each boatload of cargo. The revenue from this tax was to be divided between the Meers of Hyderabad and Khairpur

After the 1834 treaty was signed, a number of new administrative positions were created, all under British authority, for administering trade along the Indus river. Sayyid Azeemuddin Hussain was appointed to serve as the British agent in Sindh; he was based at the mouth of Indus, and was to receive a monthly salary of Rs.250. Sher Ali Khan was to be the British agent at Karachi, reporting to Captain Wade, and Lieutenant Mackeson was based at Mitthenkot in southern Punjab, and reported to Wade and Pottinger. ${ }^{141}$ Wade was soon to play a leading role in keeping Ranjit Singh out of Sindh.

Ranjit had annexed Rojhan; it had belonged to Baluchistan and was inhabited by the Mazari Baluch tribe. The places raided by the Mazaris included Mitthenkot, also captured by Ranjit Singh, and the Punjab ruler had now set his sights on Khairpur and Hyderabad. From the British point of view, the situation in the SindhPunjab region invited intervention by the British; as Pottinger put it, it gave them further incentive for "establishing a political influence throughout the whole course of the Indus'. ${ }^{142}$ To keep Ranjit Singh at bay, the Hyderabad Meers once again sought a closer relation with the British. This time, in 1835 they sent a message to Alexander Burnes, Pottinger's assistant, that a British Resident be assigned to Sindh. ${ }^{143}$

Pottinger saw here an opportunity to increase British political influence in the regions bordering the Indus with the minimum of fuss. And having a British resident in Sindh could serve as a defence against invasion of India by any other European power. ${ }^{144}$ Ranjit Singh already occupied territory close to Sindh and his empire was now larger than he could govern effectively. His death could be followed by anarchy,

\footnotetext{
141 From Secretary to the Government of India to Lieutenant Colonel Pottinger, Political consultations, 23 January 1835, no.39. NAI. Fort William, 25 December 1835, Political Consultations, 18 January 1836, no. 22. NAI.

143 Ibid.

$144 \quad$ Ibid.
} 
the anarchy would spread to Sindh if it was part the Sikh empire, and trouble on its north-western border would bring danger to British India. Ranjit Singh, therefore, had to be stopped. This meant putting more pressure on Meer Noor Muhammad. But the Meer, as well as wanting to restrain Ranjit Singh, also wanted British help to conquer neighbouring regions. The British refused this help because it would involve unnecessary fights with Ranjit Singh or the Afghans. ${ }^{145}$

Meer Noor Muhammad subsequently proposed to Alexander Burnes a new treaty that now allowed a British agent to reside anywhere in Sindh. The Resident would oversee the opening of the Indus on terms agreed to in previous treaties. $\mathrm{He}$ was not to interfere in the administration of Sindh. The treaty's final clause required that the British use their influence to protect Sindh from Ranjit Singh and, after Ranjit's death, from his successor in Lahore. ${ }^{146}$ The proposed treaty exposes the dual pressures felt by the Sindh regime in the mid-1830s; the Meers were confronted with the Sikh threat on the one hand, and growing British interference on the other.

Ranjit Singh had stayed out of Sindh so far because he did not want to offend the British; in July 1831 he had assured Bentinck that he would not invade Sindh. ${ }^{147}$ It was difficult, however, to prevent Ranjit Singh from taking Shikarpur. He had conquered large parts of Afghanistan and now claimed the tribute, which Sindh paid to the Afghan ruler. So that the Meers could have confidence in the British, Captain Wade was instructed to do his best, with both persuasion and subtle threats, to stop Ranjit Singh from annexing Sindh. The permanent establishment of a British militia inside Sindh's borders seemed to be an appropriate and effective means of keeping Sindh safe from both Ranjit and the Afghans. The British also wanted Ranjit Singh to do their bidding in relation to the Afghan fugitive Shah Shuja; the Shah had now taken refuge in Ludhiana and was engaged in intrigues that could be injurious to the stability of Sindh. ${ }^{148}$ no. 23, NAI.

Ibid. Minute by the Governor-General, Secret Consultation, 3 October 1836, no. 17, NAI. 
This situation persuaded Meer Noor Muhammad to allow a British Resident to be based in Hyderabad. In April 1836 he told Munshee Jeth Anund, the native agent at Hyderabad:

It is my wish to strengthen the bonds of friendship in the same manner that was done by my father and even to have a gentleman stationed in my country as an agent. The motive I have for this arrangement is solely to add to the present friendly relations, and object for introducing into the treaty that the

British will not allow the Sikhs or Afghans to enter Sindh... ${ }^{149}$

But Meer Sobdar and a few Baluchi chiefs were against the idea of a British Resident. Meer Sobdar remarked: 'I know you are giving Sindh to the foreigners', ${ }^{150}$ but Noor Muhammad ultimately managed to persuade Meer Sobdar to agree to his proposal. ${ }^{151}$

The British knew that, although having a Resident in Hyderabad would not be enough to give them political influence in Sindh, it would prevent Ranjit Singh from seizing Sindh territory. ${ }^{152}$ Another treaty was signed with the Meers on 20 April 1838. It stipulated that the Governor-General's council would use its influence to resolve the tension between Ranjit Singh and the Meers of Sindh. And, for the purpose of 'securing' the friendship between the British and Sindh, a British minister was permitted to reside at the Hyderabad court. The British Resident in Sindh could change his place of residence whenever this was judged necessary, and he could be accompanied by any suitable escort sent by the British government. The Meers, for their part, could appoint an agent to represent them in Calcutta. ${ }^{153}$ Colonel Henry Pottinger agent to the Governor- General of India for the affairs of Sindh, 13 April 1836, Political consultations, 16 May 1836, no. 50, NAI. Secret Department, Bhooj Residency, 11 May 1837, Political Consultations, 19 June 1837, no.30, NAI. 
The British also signed a treaty, with Meer Rustam Khan of Khairpur on 24 December 1838. It made Meer Rustam and his successors subordinate to the British; their relationship with the British had priority over connections with other Meers or states. This meant that the Meer and his successors could negotiate with the other chiefs or states only with the approval of the British government. And it also meant the Meers would not act belligerently towards other chiefs or states; any conflicts with other powers were to be arbitrated by the British government. In times of war, the Meers would provide the British with troops to the best of their means and give British forces access to military provisions held in Khairpur. The Meers' troops were also to be ready to defend the states east of the Indus if they came under threat. The treaty included an assurance that the British government would never take possession of territory belonging to Meer Rustam or his heirs, nor the fortresses built along the bank of the Indus. Furthermore, British jurisdiction would not be imposed on Khairpur. The Meer, his heir and his successors would retain absolute authority in Khairpur, and the British would not respond to any complaints made against Meer Rustam Khan. Meer Rustam was to facilitate British navigation on the Indus river, ensuring no obstruction by guaranteeing the cooperation of his subjects. The treaty allowed a British Resident to have a place at the Khairpur court. Other conditions related to the Resident were the same as those in the 20 April treaty with Hyderabad. The treaty was signed by Alexander Burnes, envoy of Lord Auckland, and was to be ratified by the Governor-General within forty five days. ${ }^{154}$

From this we can see that the British push to have Residents at the courts of Hyderabad and Khairpur was connected to the goal of getting unhindered use of the river Indus for commerce. Political and economic goals were, therefore, closely connected. Because the Meers were threatened by the Sikhs and Afghans in the 1830s, the British could see that getting political clout in Sindh required manipulating these threats. Particularly in their 1838 treaty with Khairpur, the British made clear their determination to establish British hegemony in Sindh. And they also applied the 'divide and rule' strategy, severing the Khairpur Meers' dependence on 
Hyderabad. With the signing of the December 1838 treaty, the Hyderabad Meers lost their dominance over Khairpur.

\section{Conclusion}

The British strategies in Sindh aimed to extract from the Meers of Hyderabad the rights to privileged access to the River Indus for the purpose of developing British commercial interests in north-west India. Not only did they want access to the river, they aimed to improve its navigability so as to make much more use of it as a trade route than native merchants in the states of Sindh, the Punjab and Bahawalpur had typically done in the past. Thus in Sindh in the 1830s, as they had done previously in the states of Bengal, Awadh and Gujarat, the British emerged as the dominant political player, and they used their political power to achieve economic power. The internal feuds within the family of Meers facilitated British political interventions. As they had done in other places, they turned rivalries among native power brokers to their own advantage. In this chapter we have also examined how the mercantile class facilitated the British push into Sindh.

The British were playing their 'great game' in the early nineteenth century. From the 1820s onwards, the concern among British officials about a growing threat from Russia generated two schools of thoughts in relation to the defence of British India. The Ludhiana school, to which Metcalfe and Bentinck belonged, argued that Afghanistan and perhaps western Punjab should be the Company's Middle Eastern ally against an invasion from the north. The Bombay school judged that British India could be better defended by an alliance with Persia. When Bentinck took up his position in Calcutta in 1833, the idea of a Persian mission was dropped; this was because the 1828 treaty of Turkomanchy between Persia and Russia pushed the British towards working for an alliance with Afghanistan. The forward policy promoted by the Marquess of Hastings some years earlier was favoured by Bentinck, and the push forward became even more assertive under Governor-General Lord Auckland (1836 - 1842), Events in Kabul also played a part in shaping British policy. On more than one occasion the mercantile class of Sindh facilitated the British mission to Kabul; and, as we shall soon see, it helped the British win from the Hyderabad Meers the port city of Karachi. 
In the next chapter we will discuss these developments and the way in which the British used their growingly strong political foothold in Sindh to position themselves advantageously in central Asia and against Russia. The political foothold in Sindh gained by the British in the 1830s led to full annexation in 1843. 


\section{Chapter 6}

\section{Towards Annexation}

In the previous chapter we saw that to understand why and how the British conquered Sindh we need to look further than the history of the state of Sindh. We have to situate Sindh's history in the $18^{\text {th }}$ and $19^{\text {th }}$ centuries within the context of British expansion in other parts of the world both close to and distant from Sindh. John Gallagher and Ronald Robinson make this point; they suggest that we need to look beyond the history of a specific empire, whether formal or 'informal', so as to avoid generalising too broadly and glossing over differences. ${ }^{1}$ Gallagher and Robinson's point is applicable to the case of British expansion in Sindh. Chapter four of this study has already shown how Sindh in the nineteenth century became a part of the British 'great game' to counter French and then Russian imperialism in Central Asia. Historians who have studied the British 'great game', ${ }^{2}$ however, have only taken into account British policies relating to the Sikhs, Afghanistan and Persia, ignoring the situation in Sindh. The British were interested in Sindh for its geostrategic importance, but there were other factors also which led to its annexation; these include British commercial interests, control of the river Indus, and political instability in Sindh caused by internal divisions among the Hyderabad Meers.

Eldered Pottinger (1811-1843), an independent British traveller in Herat, told an Afghan officer on 15 April 1838 that the British had no intention of extending their frontier; that they were happy with the extent of their empire and would reap its benefits. ${ }^{3}$ Developments in Central Asia, however, caused British foreign policy to take a new direction after 1838; a result was the first Afghan war and annexation of Sindh in 1843. Lord Palmerston was concerned about a recent tripartite Russian-

John Gallagher and Ronald Robinson, 'The Imperialism of Free Trade', The Economic History Review, Second Series, Vol. VI, no. 1, 1953, 1.

2 As described in Chapter 4, 'great game' was the term coined by Arthur Conolly in 1841 to describe British policy in the Middle East and Asia to counter the potential foreign threats from, for example, France and then Russia. Edward Ingram, In Defence of British India: Great Britain in the Middle East, 1775-1842 (London: Frank Cass \& Co. LTD., 1984), 2- 3. John William Kaye, Lives of Indian Officers, Illustrative History of the Civil and Military Services in India, V. II (London: A. Strahan and Co., 1867), 169. 
Persian-Afghan alliance and Persia becoming a vassal of the Muscovite kingdom. Count Simonich, the Russian representative at Tehran, was encouraging Shah Muhammad, the ruler of Persia to annex Herat, ruled by Shah Kamran. ${ }^{4}$ The Russians were behind Persian political interference in Herat. The Persian siege of Herat began on 21 November $1837,,^{5}$ and its success gave the Russians a stronghold in the city, bringing them closer to the Indian border. ${ }^{6}$ During the Governor Generalship of Bentinck (1833-1835), British policy was to keep the strong Sikh state of Ranjit Singh as a buffer between Russia and the British Indian Empire in south Asia. Lord William Bentinck therefore concentrated just on making the Indus navigable for steamships. Lord Auckland, who was appointed by the Whigs as the Governor-General of India in 1836, followed a more aggressive policy in Central Asia. He has been blamed for initiating the first Anglo-Afghan war which, according to scholars such as Sir George MacMunn, led to the annexation of Sindh. ${ }^{7}$ We have seen in the previous chapter how Sindh had become a part of the British 'great game' in the early nineteenth century. In this chapter we will study the immediate factors which were responsible for the annexation of Sindh in 1843.

\section{The First Anglo-Afghan War}

The first Anglo-Afghan war was described by E.B. Eastwick in 1849 as 'one of those 'tamashas' (spectacles) India has been so famous for'. ${ }^{8}$ The British in India had no logistical support system for carrying out the Afghan expedition. Its frontier in the north-west extended only as far as Sutlej. Ludhiana was its only cantonment in the north-west; beyond that and the Khyber Pass the Sikhs had a formidable empire. Sindh was therefore to be made a British sphere of influence before British forces

5 Sir Algernon Law, 'Memorandum by Lord Ellenborough (when out of Office)', India under Lord Ellenborough, March 1842-June1844 (London: John Murray, 1926), 5.

6 The Persians were even planning a plundering expedition in India and Turkistan with the help of the Herat army, Kaye, Lives of Indian Officers, 36, 168.

7 Lieut. General Sir George MacMunn, The Lure of the Indus Being the Final Acquisition of India by the East India Company, rev. ed., (Karachi: Royal Book Company, 1989), 44. E.B. Eastwick, A Glance at Sind Before Napier, $3^{\text {rd }}$ ed. (Karachi: Oxford University Press, 1973), 45.Eastwick's book was first published in England in 1849 under the title Dry leaves from young Egypt, 1849 
could proceed with the Afghan expedition. ${ }^{9}$ This section of the chapter will focus on the Afghan expedition and show how the British, to facilitate it, continued to impose pressure on Sindh until it was annexed in 1843. In this endeavour they were assisted by the mercantile class of Sindh. Eastwick tried to claim in 1849 that the annexation of Sindh was a consequence of the British desire to free the region from its barbarous Talpur rulers. Eastwick was endorsing the official British justification for imperialist expansion. That might be how it looked to an Englishman in Central Asia at the time. As it was, the divisions and family feuds among the Talpur rulers further helped the British to annex the province. By dividing the institutions of the Talpur Meers, they further weakened the Sindh state. ${ }^{10}$

Earlier in 1837 Alexander Burnes had been sent to Kabul by Lord Auckland on a mission that pretended to be commercial, and Dost Muhammad (1793-1863), the then ruler of Kabul, was welcoming and hospitable. He asked Burnes to help him against Persia and Ranjit Singh, the ruler of the Western Punjab. Though Burnes was willing to help Dost Muhammad, the Governor-General and his Shimla cabinet were not. Lord Auckland believed that, by helping Dost Muhammad, British relations with Ranjit Singh could be jeopardised. He planned, instead, to put Shuja ul-Mulk on the Kabul throne and to do this with Ranjit Singh's help. Shuja could be a puppet ruler for the British in Afghanistan, thus bringing it under virtual British control. Lord Auckland also wanted to put a check on Ranjit Singh expanding into Sindh. ${ }^{11}$ This was the 'great game' of Lord Auckland. Burnes was called back from Kabul and asked not to get in the way of Lord Auckland's 'great game'. Also, in October 1838 the home authority in London approved Lord Auckland's plan of installing Shuja on the throne of Kabul. This involved great intrigues on the part of the British, leading in turn to Russia carrying on its own intrigues involving the Persians in Kabul and Qandahar. The Russian envoy Captain Witkiewicz even wrote to Ranjit Singh asking his permission to visit him. Thanks to Lord Auckland's intervention,

Ibid., 45.

Ibid., 52-71.

Ward and Gooch, eds. The Cambridge History of British Foreign Policy: 1783-1919, 203. 
Witkiewicz's request was declined by Ranjit Singh. ${ }^{12}$ Burnes now realised that the older policy of overwhelming Russian trade in Afghanistan by competing with it through the Indus Commerce ${ }^{13}$ was not going to work without a display of force by the British. ${ }^{14}$

The British, realising that the security of British India was threatened by an alignment of potential rivals in the north-west, signed a tripartite treaty with Shah and Ranjit Singh in June $1838 .{ }^{15}$ Ranjit was also keen on entering an alliance with the British as this could secure his Afghan frontier. Shuja was asked by the British to abandon his claims to Shikarpur, Khairrpur and the rest of Sindh. He was also to abandon all territorial claims on either side of the Indus, including Kashmir, Peshawar as far as the Khybr Pass, which were under Ranjit Singh, and also his claims to Attock, Kutch, Hezara, Gorang, Dera Ismael Khan, Dera Ghazi Khan and the Bolan pass. These regions were to be under the control of Ranjit Singh. ${ }^{16}$ Thus this treaty was intended to settle disputes between the contending powers in territories through which the Indus flowed.

In return for being freed from Afghanistan, the Meers of Sindh were asked to pay a tribute of 20 lakhs rupees to Shuja. ${ }^{17}$ The assumption was that they were wealthy enough to pay this amount as they had long withheld payments of tribute to Kabul. Shuja, however, had already issued a farman in 1835 forgoing any claim to Sindh and Shikarpur, giving them to the Meers as 'jagir' (land holding) on a permanent basis. ${ }^{18}$ Here the word 'jagir' used by Shah Shuja does not seem to have the same meaning as the term for the Mughal land assignments to officers (jagirdars) in lieu of salary for maintaining troops for the government. The Meers, therefore,

12 Ibid., 206.

13 See chapter 5 of the thesis, Memorandum drawn up by the Governor-General on the subject of our Relations on and Beyond the Indus by Lieutenant Alexander Burnes, Calcutta, 18 May 1833, Foreign Department, 6 June 1833, no. 8, National Archives of India [hereafter NAI]. Kaye, Lives of Indian Officers, 40. From W.H. Macnaghten to Pottinger, Secret Consultation, 26 September 1838, no. 5-9, NAI. Ibid.

The Secretary with the Governor- General to the Resident in Sinde, 26 July 1838, no. 22, Correspondence Relative to Sinde: 1836-1843, (London, J.L. Cox and Sons, 1843), 41.

18 Shah Shooja -ool-Moolk to the Ameers Noor Mahomed and Nuseer Mahomed, Correspondence Relative to Sinde: 1836-1843 (London, J.L. Cox and Sons, 1843), no. 60, 85. 
had no obligation to pay tribute to Shuja ul-Mulk. ${ }^{19}$ Burnes however interpreted the word 'jagir' as tribute which was to be paid yearly, and this view was adopted by Lord Auckland. ${ }^{20}$ Out of payment of Rupees 20 lakhs, 15 lakhs were to be given to Ranjit Singh for placing Shuja ul-Mulk back on the throne and for relinquishing his claim on Shikarpur. ${ }^{21}$ The Meers of Sindh were also instructed not to enter into any engagement with the Shah of Persia as this would be inimical to British interests, and therefore a hostile act. The Meers were further asked to abrogate the article of the 1836 treaty that disallowed the passage of British troops through Sindh. The British needed to send their army to Kabul and it had to pass through Sindh. A British garrison was also to be established in Sindh. ${ }^{22}$

The British army that was organised for the Afghan expedition was called the 'Army of the Indus'. To reach Kabul, the route from Qandahar was preferable to the passes between Peshawar and Kabul, which had rugged terrains and lacked supplies. Two battalions of the Company from Bengal were to march to Kabul with another army headed by Shuja through Qandahar. The Bengal column took the route through Karachi, and was headed by General Sir Henry Fane, the commander-in-chief in Bengal. However on 9 September 1838 the Persians lifted their siege of Herat; with that one of the major reasons for Afghan expedition disappeared. ${ }^{23}$ Nevertheless, Lord Auckland decided to go ahead with the expedition. The Bengal column was reduced and now headed by General Cotton. The Bombay column of the Company army was under General Sir John Keane, who also commanded the Army of the Indus. ${ }^{24}$ The British army during this time was making plans to fortify Herat and Qandahar. The aim was to establish a secure frontier for the Indian Empire, with a puppet ruler in Afghanistan. Alexander Burnes was sent to Khairpur to arrange the

H.T. Lambrick, Sir Charles Napier and Sindh (London: Oxford University Press, 1952), 38. Ibid., 37. Ibid., 37. Ibid., 37.

The British decision to march against Herat was also put on hold when this news was known. Lord Colchester ed. History of the Indian Administration under Lord Ellenborough in his correspondence with Duke of Wellington. To Which is Prefixed, by Permission of his Majesty, Lord Ellenborough's Letter to the Queen during that Period, (London: Richard Bently, 1874), 1-136.

Sir George Fletcher MacMunn, The Lure of the Indus: Being the Final Acquisition by the East India Company, rev. ed. (Karachi: Royal Book Company, 1989), 49. 
passage of the British army and the forces led by Shah Shuja through Sindh and Qandahar. ${ }^{25}$ Once in Khairpur, Burnes started negotiating with the Meers for the purpose of taking the fortress of Bukukur. Burnes said that he thought he had 'nailed' that fortress because the 'poor chiefs' of Khairpur were 'civil' and 'well inclined' towards the British. ${ }^{26}$ Soon, however, on 9 December 1838, he reported to Henry Pottinger (who served from1838 to1840), the resident of Sindh, that he was facing difficulties in getting essentials such as transport for the passage of the army. Pottinger faced similar difficulties in Hyderabad because Meer Noor Muhammad was slow to supply camels to the British army. Pottinger then threatened the Hyderabad Meer Noor Muhammad that Karachi would be occupied if war provisions were not made available to the British. ${ }^{27}$

The other Meers of Hyderabad criticized Meer Noor Muhammad for straining relations with the British. The British threat to seize Karachi led Meer Noor Muhammad to reconsider his decision and he said he would provide the British with a few thousand camels. Pottinger believed that there was however already a loss of trust between the British and Meer Noor Muhammad and he considered the friendship between the two to be over. Pottinger said to Saiyid Takee Shah, an envoy of Meer Noor Muhammad, that he would only believe Meer Noor Muhammad if he sent him the transport and provisions for the troop. In the meantime, he would try to acquire some camels from Cutch and Gujarat. ${ }^{28}$ While the Meers of Hyderabad, intimidated by the British, were now arranging transport for the British army, Meer Sher Muhammad of Meerpur stopped the passage through his territory of 500 camels sent from the Rao of Cutch. Pottinger believed that trying to put pressure on Sher Muhammad through the Hyderabad Meers would not be very effective because Sher Muhammad was ever willing to act independently of them. ${ }^{29}$ This reveals the complexities of power relations among the various Meers of Sind and their different

25 MacMunn, The Lure of the Indus, 46-47.

26 From Sir Alexander Burnes to Sir Willoughby Cotton, 17 December 1838, no. 113, Correspondence Relative to Sinde: 1836-1843, 134.

27 From the Resident in Sinde to the Secretary with the Governor-General, 15 December 1838, no. 112, Correspondence Relative to Sinde: 1836-1843, p.131.

28 Ibid., 131-132.

$29 \quad$ Ibid. 133. 
attitudes and policies towards the British.At this time the Governor-General Lord Auckland decided to ask the Meers to meet the expenses of a British subsidiary force. Pottinger, however, believed that the Meers would not agree to meet this cost; it would have to be extracted by force. The Meers, Pottinger believed, had acquiesced to British demands so far only because they considered that they were not able to go to war with them and win; they knew about British 'power and perseverance ${ }^{\text {, } 30}$ But Pottinger also thought that the time was not right for demanding more from the Meers, and that they should not be required to maintain a subsidiary force.He was reluctant to fan the Meer's hostility. Meer Sher Muhammad had already demonstrated opposition to the British by impending the passage of the camels requested by the British army, and he had advised the Hyderabad Meers to oppose the British as well. With the exception of Meer Sobdar, the Hyderabad Meers were also lukewarm in their support for the British Afghan expedition because it was a threat to the Meers. ${ }^{31}$

Pottinger suggested to Burnes, who was at Khairpur, not to reveal the Governor-General's planned request to the Hyderabad Meers, to Meer Rustam, the principal Meer of Khairpur. Meer Rustam needed to be silenced because he was likely to relay news of the subsidiary force plan to the Hyderabad Meers. If that happened, and war supplies to the British were withheld, the British Afghan expedition would be jeopardised. ${ }^{32}$ Another problem for the British was the financing of the Afghan expedition. Pottinger reported that he had twenty five lakhs bullion and he still needed a thousand rupees for the British army in Sindh. As an expedient he proposed to stamp ten or fifteen lakhs of Hyderabad currency in Bombay. This was because the value of the Hyderabad currency was lower than the British Indian rupee. ${ }^{33}$ He further suggested that if the Meers were not ready to accede to all the British demands then they should subdue Sindh first before proceeding to

Ibid., 134. Ibid, 133,134.

From the Resident in Sinde to Sir A. Burnes, 19 December 1838, no. 114, Correspondence Relative to Sinde: 1836-184, 135.

From the Resident in Sinde to the Secretary with the Governor-General, December 1838, no. 116, Correspondence Relative to Sinde: 1836-184, 137. 
Afghanistan. Pottinger also proposed that the Meers of Sindh be asked to replace the Sindhi rupee with the Company's currency, or a currency of the same standard with Shuja ul-Mulk's name on it. The idea was to reduce the financial pressure on the British, and the expense of the Meers. The Meers were also to provide five thousand camels, of which four thousand were to go with the British army in Afghanistan and the remaining thousand kept by the British subsidiary force in Sindh. ${ }^{34}$ Thus we see that, to meet the resources required for the Afghan expedition, the British by the end of 1838 had made plans either to use Sindh's resources or, if the Meers refused to meet the British demands, to annex Sindh.

In Khairpur, Meer Rustam was favourably inclined towards the British, but Meer Mubarak Khan's faction was not. Burnes, on 11 December 1838 sent his agent Munshi (writer) Mohan Lal, a Kashmiri who had written a biography of Dost Muhammad, to deliver text of a proposed treaty that provided for handing over the fortress of Bukkur to the British. ${ }^{35}$ Meer Rustam was not ready for this, but Parveen Talpur argues that Munshi Mohan Lal's persuasion won him over. ${ }^{36}$ Meer Rustam confessed that the reason for his favourable attitude towards the British was his weakness, advanced age and his fear of the consequences of British wrath for himself, his children and his tribe if he opposed them. ${ }^{37}$ Meer Rustam signed the treaty of ten articles with the British on 24 December 1838 and made Khairpur a British protectorate, even though Meer Muhammad had tried to stop him from signing the treaty. ${ }^{38}$

By signing this treaty Meer Rustam was to become a friend and ally of the British; in return for his loyalty, the British promised to protect Meer Rustam and his territory. Meer Rustam now became subordinate to the British and was expected to

$34 \quad$ Ibid., 137.

35 From Sir A. Burnes to the Secretary with the Governor-General, Foreign Dept., 25 December 1838, no. 118, Correspondence Relative to Sinde: 1836-1843, 138.

36 Parveen Talpur, The Talpur Rule in Sindh (Lahore: Ferozsons, 2002), p. 73; From Sir A. Burnes to the Secretary with the Governor-General, Foreign Dept., 25 December 1838, No. 118 Correspondence Relative to Sinde: 1836-1843, 138.

37 From Sir A. Burnes to the Secretary with the Governor-General, 28 December 1838, no. 121, Correspondence Relative to Sinde: 1836-1843, 142.

38 From Sir A. Burnes to the Secretary with the Governor- General, 25 December 1838, No. 118. Correspondenc Relative to Sinde: 1836-1843, 138. 
co-operate with them. The treaty required that the Meer make no contact with any other chiefs without British permission. The Meer or his successors were also not allowed to act aggressively towards their subjects. All disputes were to be settled by the British government. The Meer was asked to provide the British with troops and provision them during war. If the region on the other side of the Indus was threatened then the Meer and his successors were to allow the British to take measures to defend that region. For their part, the British would not try to possess any dam, drain or fortress of the Meer on either side of the Indus. ${ }^{39}$

In return the treaty endorsed the Meer's absolute rule and jurisdiction within his territory. The British were not to attend to any complaint against the Meer made by his subjects or relatives. The Meer was also to seek co-operation with all the other Meers and local chieftains within his territory for the development of commerce. The treaty also provided for the stationing of British minister in Khairpur and the Meer was given the option of sending his agent to the British headquarter. The minister was allowed to change his place of residence within the territory whenever and wherever was expedient. He was also allowed to be accompanied by an escort when needed. A separate treaty was signed on the same day with the Meer of Khairpur to hand over the British the fortress of Bhakkur to be used during time of war. ${ }^{40}$ It is not surprising that Meer Rustam believed that he had been wronged by the British. He felt that he was their friend, yet they demanded the handover of Bhakkar despite knowing that he was opposed to this. Even more dismaying was the apparent friendliness towards the Hyderabad Meers. Karachi had not been seized by Lord Auckland, even though Meer Noor Muhammad was said to be the enemy of the British. ${ }^{41}$ Thus we see Hyderabad and Khairpur competing with each other and Khairpur suggesting that the British take measures against Hyderabad. Also native officials like Munshi Mohan Lal became a British collaborator in Sindh, aiding them in their political push into the region. However, while the British were using the term

\footnotetext{
39 Treaty with the Khyrpore State, with Notes of Explanation by Sir A. Burnes, 25 December 1838, no. 119, Correspondence Relative to Sinde: 1836-1843, 139.

40 Treaty between the East- India Company and Meer Roostam Khan of Khairpur, 10 January 1839, no. 131, Correspondence Relative to Sinde: 1836-1843, 150. Ibid., 139.
} 
'defensive preparations' for their advance, this policy was almost entirely driven by the need of their more aggressive Afghan expedition. Soon after Meer Rustam came under the protection of the British. Meer Mubarak, another Meer of Khairpur, changed his stance and appealed to Burnes to grant him protection as well. Burnes however declined this request. Meer Rustam now asked Burnes to engage with the junior Meers of Khairpur such as Meer Mubarak in the same way in which Auckland had done in Hyderabad. Burnes responded by saying that Auckland would not agree to this because Meer Mubarak had opposed the British previously. Also Pottinger had reported to Burnes that the Hyderabad Meers were encouraged by Meer Mubarak's resistance to the British. Burnes as a consequence refused to grant protection to Meer Mubarak. Meer Rustam at this stage seemed to be uniting all the junior Meers of Khairpur and strengthening Khairpur's position against Hyderabad. He put it to Burnes that the British were dividing the Khairpur Meers, and he had good grounds for saying this. Burnes' justification for excluding Meer Mubarak was that 'the friends and foes must be separated.' 42

This policy of dividing political factions in Khairpur and pitting one group against another had also been applied in other regions of British India; it was used, for example in Bengal and Awadh when the British were expanding their power there. It is fair to say that factional friction among the various ethnic, religious, cultural and caste groups in India in many cases was the result of deliberate 'divide and conquer' or 'divide and rule' strategies used by British empire-builders in both the colonial and pre-colonial phases of their expansion in South Asia. ${ }^{43}$ Shuja ulMulk's army and that of the British were soon to enter Sindh on their way to Kabul. Shuja ul-Mulk's army was to reach Khairpur first. Meer Rustam, being a dependent of the British now, asked Burnes how he should deal with Shuja ul-Mulk and how much money he was to advance him. His aim was to free Khairpur from paying any Correspondence Relative to Sinde: 1836-1843, 141,142. Effects of Colonialist "Divide and Rule" strategy upon the Colonised people', Science and Society, Vol. 37, no. 2, 1973, p. 13, David Page, Prelude to Partition: The Indian Muslims and Imperial System of Control, 1920-1932 (New York: Oxford University Press, 1982), xiii-288. 
tribute in future and to show conciliation towards the British. Burnes asked him to supply Shuja with whatever supplies he had and to pay him double the amount paid before. Meer Rustam readily agreed to all these demands and welcomed Shah Shuja in Khairpur. Burnes also informed Meer Rustam that the Bengal column of the British army under Sir Henry Fane was soon to reach Sindh. Meer Rustam promised Burnes that he would give every kind of assistance to facilitate the passage of the British expedition through Sindh. ${ }^{44}$ The cooperative relationship with Meer Rustam saw the British reconsider their position in relation to the junior Meers of Khairpur; on 28 December 1838, Meer Mubarak, Meer Muhammad and Meer Ali Murad were all brought under the same kind of British protection enjoyed by Meer Rustam. ${ }^{45}$

The next measures taken immediately by the British in Sindh were to obtain toll-fee rights to navigation on the Indus and to make the Meers of Hyderabad and Khairpur agree to maintain a British subsidiary force. Auckland declared that he did not wish to acquire any territory in Sindh. To achieve these two goals, Auckland's strategy was to weaken the Meers by making them independent of each other. ${ }^{46}$ With the Khairpur Meers already British dependents, the challenge for the British now was to make the Hyderabad and Meerpur Meers agree to their demands. Pottinger was instructed to make arrangements in Shikrapur for the arrival of the Bombay column of the British force under Sir John Keane. ${ }^{47}$ Pottinger complained that Munshi Jeth Ananud, the native agent at Sindh's Hyderabad court, had told him that despite agreeing to the clause of the 1836 treaty requiring that the Meers would sever all contacts with Persia, Meer Noor Muhammad of Hyderabad had sent a letter to the ruler of Persia in mid-July $1838 .{ }^{48}$ All the Meers of Hyderabad had signed the letter

From Sir A. Burnes to the Secretary with the Governor-General, 28 December 1838, no. 121, Correspondence Relative to Sinde: 1836-1843, 143.

45 Agreement with Meer Moobarak Khan of Khyrpore, No. 122, Agreement with Meer Mahomed Khan of Khyrpore, No. 123, Agreement with Meer Ali Moorad Khan of Khyrpore, No. 124, 28 December 1838, Correspondence Relative to Sinde: 1836-1843, 143-144. From the Secretary with the Governor-General to the Resident in Sinde, 31 December 1838, No. 125, Correspondence Relative to Sinde: 1836-1843, 145-146.

47 Ibid., 146

48 From the Resident of Sindh to the Secretary with the Governor-General, 13 August, 1838, no., 23, Correspondence Relative to Sinde: 1836-1843, (London: J.L. Cox and Sons, 1843), 42. 
except Meer Sobdar. ${ }^{49}$ Lord Auckland believed that since Meer Noor Muhammad and all the other chiefs of Talpur except Meer Sobdar were Shias, they were, for sectarian reasons, biased towards the Persians. ${ }^{50}$ Lord Auckland therefore considered placing Meer Sobdar, who was a Sunni and loyal to the British, as the principal Meer of Hyderabad. ${ }^{51}$ The Resident at Hyderabad had briefed Auckland about where the loyalties of all the Meers lay and this enabled Auckland to shape his policy for the various parts of Sindh. It was reported that Meer Noor Muhammad had asked his cousin Meer Meer Muhammed to side with Persia but he refused to do so, valuing the British friendship more. Meer Noor Muhammd's antipathy to the British was such that he refused even to provide a site for the building of a British residency, and believed that the British resident's presence in Hyderabad was to facilitate the British military advance into Sindh. Efforts were then made to explain to Meer Noor Muhammed that the security of British India was the reason why the British army would pass through Sindh en route to Afghanistan, and this would not affect the friendship between Sindh and the British. Meer Noor Muhammad, however, was less than convinced by this explanation. The British resident had reason to consider him to be unfriendly towards the British. ${ }^{52}$

The British expected that some Meers of Hyderabad would not allow the British troops to remain in Shikarpur, nor sign any treaty with the Khairpur chief Meer Rustam Khan, and therefore force would be needed to subdue them. ${ }^{53}$ Going to war against Noor Muhammed was easier than trying to negotiate an agreement about the British army's passage through Sindh. Alexander Burnes suggested to Pottinger that the British should deal with the various Meers according to their dispositions. In From I.P. Willoughby Esquire, the Resident of Sindh to Macnaghten Esquire, Secretary to the Government of India, 13 August 1838, Sindh Residency Camp, Foreign Department, Secret Consultations, 14 November 1838, no.35, NAI. The Governor-General to the Secret Committee, 24 September 1838, Correspondence Relative to Sinde: 1836-1843 (London, J.L. Cox and sons, 1843), no. 33, 54.

51 From Henry Pottinger, to W.H. Macnaghten, Secretary to the Government of India, 8 October 1838, Secret Consultations 14 November 1838, no.40-46, NAI.

52 The Resident in Sinde to the Secretary with Governor-General, 25 October 1838, No. 58, Correspondence Relative to Sinde: 1836-1843 (London: J.L. Cox and Sons, 1843), 83. Ibid, 85.
} 
other words, the unfriendly Meers should be managed differently from those who were well disposed towards the British. ${ }^{54}$

The British believed that Meer Nasir Muhammad was favourably inclined towards the British; he was influenced by Meer Noor Muhammad with whom he shared the same religion of Shia Islam. ${ }^{55}$ The British Resident reported that Meer Meer Muhammed and Meer Sobdar were inclined towards the British as well. In fact, Meer Sobdar wanted British intervention to free Sindh from Afghan suzerainty and agreed to pay a sum of money to Shuja-ul-Mulk. ${ }^{56}$ The Khairpur Meers were found to be on the same terms with the British as they were in 1832, but the Meer of Meerpur, Sher Muhammad, did not want any correspondence or relations with the British. ${ }^{57}$

The attitude of the Hyderabad chief, Meer Noor Muhammad, towards the other Meers was reflected in negative comments about them made to the munshi or agent of Pottinger. Meer Muhammad, he said, was 'worse than a fool', and he suggested that Meer Muhammed Khan should become just a pensioner of Meer Noor Muhammed rather than sharing the power with him. Meer Sobdar was called a 'madman' and 'liar' by Meer Noor Muhammed. ${ }^{58}$ This discord among the Meers was reported by the British Resident to the Governor-General. It seems that the Meers suffered from the same kind of disunity which had weakened the ruling family of Carnatic on the eve of its annexation by the British. ${ }^{59}$ However, to deal with the British, Meer Noor Muhammed, Meer Nasir Muhammed and Meer Meer Muhammad wanted to act in tandem with the Meer of Khairpur. Alexander Brunes reported that Meer Noor Muhammed, Meer Nuseer Muhammed and Meer Meer Mumhammed all wrote to Meer Rustam Khan of Khairpur to learn his decision Sinde: 1836-1843, (London: J.L. Cox and Sons, 1843), 87.

$55 \quad$ Talpur, Talpur Rule in Sindh, 75.

56 The Resident in Sinde to the Secretary with Governor-General, 25 October 1838, No. 58, Correspondence Relative to Sinde: 1836-1843 (London: J.L. Cox and Sons, 1843), 82.

$57 \quad$ Ibid. 84.

$58 \quad$ Ibid. 84.

59 Michael H. Fisher ,'The Nawabs of Carnatic and the English East India Company' in Michael H. Fisher ed. The Politics of the British Annexation of India 1757-1857 (Delhi: Oxford University Press, 1993), 94-121. 
regarding the British because whether or not to ally with or go to war against the British should, in their view, be a collective decision. ${ }^{60}$ Meer Rustam was perplexed by this overture; he advised Burnes that he wanted to continue his friendship with the British and that he was ready to reject the Hyderabad Meers' proposal if Burnes recommended he do so. ${ }^{61}$ Meer Rustam's attitude won him favour with the British; they were ready to pull him away from Hyderabad Meers' supremacy and make his state their protectorate. ${ }^{62}$

On 6 January 1839 Pottinger reported to H. Torrens, Secretary to the Governor-General, that the Meers of Hyderabad had refused to allow a British force to enter their territory. About the Meers' political behaviour, Pottinger reported that 'their character has been so shifting in nature'. ${ }^{63}$ The Meers were also reluctant to provide the British troops with camels when they landed in the Indus Delta on their way to Kabul. On 15th January 1839, Henry Pottinger proposed to Lord Auckland a treaty with twenty four articles that the Hyderabad Meers be required to sign.

Auckland also wanted to create division among the Hyderabad Meers on the issue of the payment of a subsidy for the British army. To press the Meers to agree to British demands, Auckland sent Lieutenant Eastwick, Colonel Outram and Lieutenant Leckie to Hyderabad. ${ }^{64}$

Pottinger wrote to Sir William Macnaghten, a British civil servant, saying that, for the passage of the army through Hyderabad, grain, camels, boats and money were needed. He did not trust the Meers to supply these to the British forces, particularly after they demonstrated their disloyalty by writing to the Shah of Persia. About the Meers, Burnes further observed that they would ally with any one

From Sir Alexander Burnes to the Secreatry with the Governor- General, 26 October, 1838, no. 61, Correspondence Relative to Sinde: 1836-1843, 86. Ibid.

From Sir A. Burnes to the Resident in Sinde, October 28, 1838, no. 62, Correspondence Relative to Sinde: 1836-1843, 87.

From the Secretary with the Governor-General to the Resident in Sinde, 10 January 1839, no. 129, Correspondence Relative to Sinde: 1836-1843, 148.

Robert A. Huttenback, British Relations with Sindh 1799-1843, an Anatomy of Imperialism, (California: University of California Press, 1962), 49. 
powerful. ${ }^{65}$ The mercantile class of Sindh then came forward to help the British by providing the British troops with food and supplies. Seth Naomal Hotchund

Bhojwani, a famous merchant of Karachi from the tribe of Lohano, supplied camels to the British army on their way to Kabul. Naomal became the agent of the British and he supplied grain to the British army on its way to Shikarpur. Naomal sent the grain to Godabari from where it was relayed to the English through his agent, Madho. The sardar (chief) of the region through which the grain was transported illegally, Jam Mehar Ali Khan, wanted to let the Meers know of this smuggling. Naomal, however, by bribing the sardar with Rs. two thousand, stopped him from reporting to the Meers. ${ }^{66}$

The Meers' authority over Sindh was fading at this stage. Due to the hoarding of grain by Noamal, the price of grain rose in the city and city residents took to looting his warehouse. The Meers however, were made to compensate Noamal (now under the protection of the British) for his loss by paying him Rs twenty-seven lakhs. Also, Pottinger had colluded with Naomal in a counterfeit currency scheme that economically weakened the Meers of Sindh. Noamal handed over the counterfeiting work to his friend Nanakchand Pari, who continued to do it for two years and made a huge fortune. Naomal was summoned by the Meer Noor Muhammad Khan to his court and was reprimanded for the damage he was doing to the Meer state. He was asked to stop the activities that were undermining the state. Naomal then went back to Pottinger and reported what had happened to him. Pottinger advised him to ignore the Sindh government. ${ }^{67}$

There were other signs showing that the Sindh state was in decline. The law and order situation had deteriorated and this made powerful businessmen like Naomal even more politically powerful. For example when Captain Hand was murdered in Karachi by some disciples of Caliph Chakur, Seth Naomal took charge

65 From Henry Pottinger to Macnaghten, 4 October 1838, Hyderabad, Secret Consultations, 14 November 1838, no. 40-46. NAI. 
of punishing the culprits by tracking them down and presenting them to the Meers of Hyderabad for trial. ${ }^{68}$ Naomal also assisted the British resident in Bhooj to secure a loan, on his guarantee, for the purchase of horses from the Rais of Cutch. Seth Noamal himself repaid the loan within eight days of its remission to the Rai. ${ }^{69}$ Thus we see in Sindh, as in many other parts of India in the eighteenth century, the emergence of a powerful mercantile class whom C.A. Baily and Sanjay Subramanyam have called the 'portfolio capitalists'. Their economic and political capital played no small role in the growth of British power. Both Subramanyam and Bayly have contended that this capitalist class emerged after the demise of the Mughal Empire in the eighteenth century and provided material support to British expansion in India. ${ }^{70}$ It is important to note that these revisionist historians, unlike Irfan Habib, do not depict the late eighteenth and early nineteenth century as a period of universal economic decline. There were substantial pockets of wealth in Sindh and in many other successor states that arose and prospered during this period. ${ }^{71}$ Wealthy businessmen saw benefit in supporting the powerful British against the weakened local rulers.

The task of presenting to the Hyderabad Meers the treaty that Pottinger has proposed to Lord Auckland on 15th January 1839 was given, on 20 January, to Lieutenant Eastwick, the assistant Resident of Sindh. The following day Eastwick wrote to Pottinger to warn that the Hyderabad government was preparing for war with the British because they were not ready to accede to any of the British demands. ${ }^{72}$ The Army of the Indus was near Hyderabad when Eastwick presented the

Naomul Hotchand and H. Evan M. James, A Forgotten Chapter of Indian History as Described in the Memoirs of Seth Naomul Hotchand of Karachi ..., Oxford in Asia Historical Reprints from Pakistan (Karachi: Oxford University Press, 1982).

$69 \quad$ Hotchand and James, A Forgotten Chapter in Indian History, 97-98.

70 Sanjay Subrahmanyam and C.A. Bayly, 'Portfolio Capitalist and the Political Economy of the Early Modern India' Indian Economic and Social History Review, V. 25, no. 4, 1988, 401-424. Ibid., p. 401-424; Irfan Habib, 'The Eighteenth Centuruy in the Indian Economic History', in Seema Alavi ed. The Eighteenth Century in India (New Delhi: Oxford University Press, 2002), 57-83.

72 From Lieutenant Eastwick to the Resident in Sinde, 21 January 1839, no. 159, Correspondence Relative to Sinde: 1836-1843, 159. 
treaty to the Meers on 22 January $1839 .{ }^{73}$ According to the proposed treaty the Hyderabad government and the British government were to become perpetual friends and ally. Also all the clauses of the previous treaties signed between the two parties remained valid and were to be honoured. The Governor-General also asked the Meers to allow the stationing in Thatta of a British force, the strength of which was to be decided later by the Governor-General. A British cantonment was now to be built there. When this provision of the treaty was read out to the Meers they requested that the strength of the force that the British intended to keep in Thatta be specified. Meer Noor Muhammad also declared that a British force was not really necessary, but he seemed to be giving his consent to it. ${ }^{74}$ This shows that the Meers were concerned about Hyderabad's security in the face of Britain's military assertiveness, and that they did not have complete trust in the British even though they had previously entered into a treaty of friendship with them.

The draft treaty also included a clause requiring that the Meers Noor Muhammad Khan, Nasir Muhammad Khan and Meer Muhammad Khan make an annual payment to the British for the maintenance of a British force in Hyderabad. Meer Sobdar was excluded from this arrangement. By excluding him the British wanted to secure a powerful ally among the Baluchis. ${ }^{75}$ When this clause was read out to the Meers by Eastwick, the Meers expressed the fear that such a payment would impoverish them Noor Muhammad told Eastwick: 'we ought never to have granted a road through our territories; that was my act alone; all the Baluchis predicted what would happen; this is the consequence of friendship. ${ }^{76}$ Eastwick's reply to this shows very clearly the dilemma that the Meers faced in Sindh at that time. He said:

From Eastwick to the Resident in Sinde, 26 January 1839, no. 143, correspondence Relative to Sinde: 1836-1843., 164.

From Lieutenant Eastwick to the Resident in Sinde, 26 January 1839, no. 143, Correspondence Relative to Sinde: 1836-1843, 163-168.

From the Resident in Sinde to Lieutenant Eastwick, Assistant Resident in Sinde, 13 January 1839, no. 132, Correspondence Relative to Sinde: 1836-1843, 151.

From Lieutenant Eastwick to the Resident in Sinde, 26 January 1839, no. 143, Correspondence Relative to Sinde: 1836-1843, 163. 
This is the consequence of a want of friendship; you have only to thank yourself; had a road not been granted we should have taken it by force. The empire of India is in the hands of the British. We have the power to reward our friends and to push our enemies....the independence of Sinde was provided for on the most moderate and just conditions. Would the Maharaja Runjeet Singh,would his Majesty Shah Shooja, if it had been left to them, have had the same consideration $?^{77}$

It makes clear the way in which the British played on the fears of the Meers their fear of Ranjit Singh's ambitions, and their desire to be free of the obligation to pay tribute to Kabul.

To justify the terms in the proposed treaty, Eastwick further pointed out that the treaty would actually bring prosperity to the Meers. He said that, by stationing a British force in Sindh,

... employment would be given to thousands, a vast influx of capital would encourage commerce and manufactures, this would eventually find its way into the treasures of their Highness. The Indus now so barren, would team with vessels, jungles, would yield to the plough and prosperity succeed to decay and depopulation. ${ }^{78}$

Actually, Eastwick believed that Meer Noor Muhammad was not concerned with how the treaty might benefit Sindh; all that the Meer wanted was to secure his shikargah (hunting ground) and his treasure. Whether Eastwick's opinion of the Meers and Sindh was fair is not certain, but we must take into account the strong possibility of bias in the depiction that we find in his writing of the state of Sindh and the Meer elites. But it does seem to be true that although the Meers levied heavy tolls on shipping on the Indus, both intra-tribal or intra-family feuds and British claims on resources such as camels, boats, and other goods did indeed constitute 
threats to the Meer families' property and wealth. They feared being surrounded by powerful neighbours such as the British in India and Ranjit Singh in Punjab; there was as well the ever-lurking danger of tribute-collecting excursions from Kabul. Eastwick quoted one of the Meers saying: 'you talked about the people; what are the people to us, poor or rich? What do we care, if they pay us revenue?...Hindustan was rich, and that is the reason it is under your subjection....give us our hunting preserve and our own enjoyment free from interference, and that is all we require. ${ }^{79}$ This, in Eastwick's view, was further evidence of the parlous state of the Sindh government and endorsed his belief that Sindh's subjugation by the British was desirable. To justify this view he wrote: 'They [Meers] are....Barbarians of the rudest stamp, without even barbarous virtues. ${ }^{80}$ The use in British records of the term 'barbarous' in relation to the Meers became more frequent from this time onwards, and during the years 1840 and 1841 we find arguments for the annexation of Sindh being justified by the assertion that the Meers were barbarous and, towards their subjects, tyrannical.

According to another provision of the treaty, the jacedads (land grant holders), wazefadars (pensioners), jagirdars (tahsil or district administrator ) and the various chiefs of the tribe of Baluchis were allowed the same rights to their holdings as before, and the Meers were to ensure that they did not make trouble for the British. ${ }^{81}$ The Meers objected to this on the ground that the treaty would give too much power to the chiefs under them making them independent. ${ }^{82}$ By means of the treaty, the British also made clear to the Meers that they would not interfere with any matters related to the internal administration of Sindh. ${ }^{83}$ Because it was favourable to Correspondence Relative to Sinde: 1836-1843, 165.

$80 \quad$ Ibid., 166.

81 Draft of the treaty to be proposed to the Ameers of Hyderabad, no. 133, Correspondence Relative to Sinde: 1836-1843, 154.

82 From Lieutenant Eastwick to the Resident in Sinde, 26 January 1839. no. 143, Correspondence Relative to Sinde: 1836-1843, 166.

83 Draft of the treaty to be proposed to the Ameers of Hyderabad, no. 133, Correspondence Relative to Sinde: 1836-1843, 154.
} 
them, the Meer easily agreed to this provision. ${ }^{84}$ The British also promised that they would entertain no complaints against the Meers whether made by persons of any caste or Hindus or Muslims. ${ }^{85}$ This reference to a caste by the British probably meant the Hindu Bania community of Sindh. ${ }^{86}$

The treaty also provided for British protection of Sindh against any foreign encroachment. ${ }^{87}$ Eastwick, when reading out the treaty to the Meers, also emphasised the benefits that British protection against the Sikhs and the Afghans would give them, and the Meers readily agreed to that clause. This again shows that the British were ingratiating themselves by exploiting the Meers' fears about their aggressive neighbours at the same time as, under the garb of a 'friendly' treaty, introducing measures that would enfeeble them politically. The British, through the treaty, endeavoured to get their currency, which was equal to the Timuri currency, adopted in Sindh. While coining the Company rupees the Meers had to consider paying off all the dues that they still owed the British for their freedom from Afghanistan. ${ }^{88}$ The Meers agreed to this provision also. The treaty also specified that the GovernorGeneral of India would give authority to the Resident of Sindh to mediate disputes among the Meers that were more than minor disputes. If it happened that the Baluchi chiefs under the Meers rebelled against the Meers or had any dispute with them, then the treaty required that the Governor-General decide the case and punish the offender. The British justified these provisions of treaty on the ground that they would ensure the peace and stability of Sindh. ${ }^{89}$ The proposed treaty also prohibited the Meers from having dealings with any other foreign power without the permission of the British government; the only exception was friendly correspondence with their immediate

The Resident in Sinde to Lieutenant Eastwick, Assistant Resident in Sinde, 13 January, no. 132, Correspondence Relative to Sinde: 1836-1843, 151.

Draft of the treaty to be proposed to the Ameers of Hyerabad, no. 133, Correspondence Relative to Sinde: 1836-1843, 154.

From the Resident in Sinde to Lieutenant Eastwick, Assistant Resident in Sinde, no. 132, Correspondence Relative to Sinde: 1836-1843, 151. Ibid., 154. Draft of the treaty to be proposed to the Ameers of Hyderabad, no. 133, Correspondence Relative to Sinde: 1836-1843, 154-155.

From the Resident in Sinde to Lieutenant Eastwick, Assistant Resident in Sinde, no. 132, Correspondence Relative to Sinde: 1836-1843, 152. 
neighbours. ${ }^{90}$ Also, if the British entered into any treaty that concerned Sindh, the British would advise the Meers about the treaty terms. Because these provisions were highly favourable to the Meers, they did not oppose them. The treaty also demanded that when high tides made the Indus unnavigable, Karachi was to be used as an entrepot for goods shipped from Bombay to Sindh. The Sindh government was to assist in the transport of all the supplies to the British by sending a guard from Thatta. ${ }^{91}$ Meer Muhammad Khan strongly rejected this provision of the treaty saying that the British were not allowed into Karachi. Eastwick reacted by threatening Britain's annexation of Karachi if the Meers prevented access to the city by British merchants and officials. ${ }^{92}$ Meer Noor Muhammad also opposed this provision, saying that it would never be accepted by the Meers. ${ }^{93}$

The draft treaty proposed that the Meers allow the British to build a warehouse in the port of Karachi. Duty was to be paid on goods entering Sindh by way of Karachi. These provisions were also not agreeable to the Meers. Pottinger suggested to Eastwick that, to make the Meer accept the treaty, he should point out that the Indus was navigable and could carry goods to Hyderabad for much of the time, so the use of Karachi would be minimal. Also, prohibiting British access to Karachi would stymie that city's trade, and this would be unfavourable to the Meers. ${ }^{94}$

Another provision of the treaty specified that Indus traffic ( $a m a d$ wa ruft) would be increased by the stationing of a British militia in Hyderabad, and the Indus thus would be opened as a trade route. To stimulate trade the government was to abolish all Indus River transit tolls on goods unloaded at places between the mouth of the Indus and the city of Ferozpur, which was on the border between East Punjab

Draft of the treaty to be proposed to the Ameers of Hyderabad, no. 133, Correspondence Relative to Sinde: 1836-1843, 155.

Ibid., 155.

From Lieutenant Eastwick to the Resident in Sinde, 26 January 1839. no. 143, Correspondence Relative to Sinde: 1836-1843, 166. Ibid., 166.

From the Resident in Sinde to Lieutenant Eastwick, Assistant Resident in Sinde, no. 132, Correspondence Relative to Sinde: 1836-1843, 152. 
and Sindh. ${ }^{95}$ The Resident of Sindh, while explaining the usefulness of this clause to Eastwick, said that the Meers never earned more than three thousands rupees from tolls collected on merchandise shipped along the Indus. So the Meers would not incur much of a loss by relinquishing this levy and they would benefit from the big stimulus it would give to trade; thousands more merchants would come to Sindh. Furthermore, it was to be pointed out to the Meers that the income they would get from transit duties levied on the greatly increased volume of goods now passing through Sindh, would be much more than the income they received from the duties levied on goods entering Sindh through the seaport. ${ }^{96}$ The Meers' reaction to the abolition of tolls on river-trade goods was related to their concern about whether Ranjit Singh had also abolished these tolls or not. ${ }^{97}$ As we have seen, the Meers had good cause to question British motives vis-à-vis Sindh, and were quick to resent any preferential treatment of the Sikhs, who were a threat to the Meers at this time.

According to another treaty provision, tax or duty was to be levied on all goods that were imported into or exported from Sindh. The merchants were allowed to keep at the entrance of Sindh, near Karachi the goods that they had brought without incurring a tax. However, if any merchant sold their goods there or anywhere else, he was liable to pay duty. ${ }^{98}$ The Meers were also to provide, to the best of their ability, an armed force if the British asked for one, and the cost of this was to be deducted from the payment that the draft treaty specified the Meers were to pay to the British. ${ }^{99}$ The response of the Meers to this provision helps us understand why they agreed to an alliance with the British. They said: 'with English artillery and the Beloochee swords, the whole world might be subdued. ${ }^{100}$ Into that response we can also read a miscalculation by the Meers of the colonial power's real

\footnotetext{
95 Draft of the treaty to be proposed to the Ameers of Hyderabad, no. 133, Correspondence Relative to Sinde: 1836-1843, 155. Correspondence Relative to Sinde: 1836-1843, 152.

97 From Lieutenant Eastwick to the Resident in Sinde, 26 January 1839. no. 143, Correspondence Relative to Sinde: 1836-1843, 166. 
intention and naïve optimism about the advantages for them of collaboration with imperial Britain. The Meers also wanted to prevent the British from siding with Ranjit Singh against them. ${ }^{101}$

Meer Sobdar was to be exempt from accepting most of the British demands that Meer Noor Muhammad Khan, Meer Muhammad Khan and Meer Nasir Khan were expected to accept. Meer Nasir Muhammad protested about this distinction, saying that 'all the world is aware that I have no money.' Meer Nasir Muhammad reacted by saying 'We are slain.' ${ }^{102}$ The British, however, had already firmly decided on their strategy, and they were to apply it in their dealings with the various Meers of Sindh. As noted earlier, they wanted a strong ally in Hyderabad, and they cultivated Meer Sobdar as an ally by treating him more favourably. The treaty nonetheless gave assurance to the Meers that they and their successors would retain their possessions and promised that they and the British would have mutual friends and foes. ${ }^{103}$ Through the treaty the British also 'made mischief' by differentiating between the interests and prerogatives of certain individuals. Meer Nasir and Meer Muhammad were to be made aware that they were subordinate to Meer Noor Muhammad. The purpose here was to stir up among these Meers hostility towards Meer Noor Muhammad, a purpose made clear in Eastwick's correspondence with the Resident of Sindh. ${ }^{104}$ This is another example of the divide and rule or divide and conquer strategy that the British used to secure their interests in Sindh.

Broadly speaking, the Meers resented the treaty, saying the British had been persecuting them from the time of their arrival in Sindh. To this Eastwick replied that the Talpur's friendship was questionable; they had not cooperated with the British when their help was needed to facilitate the expedition to Kabul. ${ }^{105}$ Eastwick Correspondence Relative to Sinde: 1836-1843, 166. From Lieutenant Eastwick to the Resident in Sinde, 26 January 1839. no. 143, Correspondence Relative to Sinde: 1836-1843, 166.

103 Draft of the treaty to be proposed to the Ameers of Hyderabad, no. 133, Correspondence Relative to Sinde: 1836-1843, 155-156. From Lieutenant Eastwick to the Resident in Sinde, 26 January 1839. no. 143, Correspondence Relative to Sinde: 1836-1843, 166. 
again emphasised the advantages the Meers could enjoy by signing the treaty and bringing Sindh closer to the British. Noor Muhammad did not agree. The Meer rejected the draft treaty on 23 January 1839 and dismissed Eastwick from the Hyderabad court. The next day Meer Noor Muhammad, Meer Nasir Muhammad and Meer Muhammad started preparing for a military resistance against the British. Meer Sher Muhammad too, in resentment, marched from Meerpur to Hyderabad. ${ }^{106}$ Troops were mobilised on either side of Indus. The Meers called on their Baluchi chiefs to go armed into the British camp and act menacingly. The Meers also prohibited the sale of merchandise to the British. ${ }^{107}$ The Resident of Sindh now decided that it was time to forcibly occupy Karachi. Acknowledging the help that Seth Naomal Hotchand Bhojwani, had given to the British, he asked Fredrick Maitland who was the naval commander in chief to protect Seth Naomal and his family in Karachi. ${ }^{108}$ The British Resident's concern to protect Naomal again draws our attention to the important connection between the local mercantile class and the British colonisers in the precolonial era

The help that local men of commerce gave the British is demonstrated in a number of scholarly studies; one example is the work of Lakshmi Subramanian. Subramanian points out that, in precolonial India, the Hindus of the caste of Bania in Gujarat, and banking firms such as Hari Bhakti in the state of Baroda, the Poddars in Ramgarh, the Kashmiri Mal in the state of Awadh and the Jagat Seths in Murshidabad all cooperated with the British and supplied them with credit. ${ }^{109}$ David Cheesman has studied the relations between the Banias and the British in the region of Sindh. In his opinion those banias who had trading relations with Afghanistan, Baluchistan, the Punjab and the British and were settled in commercial centres such as Calcutta, Bombay, Madras in India, and also in Bokhara, Astarkhan and Kabul, all

From Sir A. Burnes to the Secretary with the Governor- General, 1 February 1839, no. 149, Correspondence Relative to Sinde: 1836-1843, 172.

From Lieutenant Eastwick to the Resident in Sinde, 26 January 1839. no. 143, Correspondence Relative to Sinde: 1836-1843, 167.

From Resident in Sindh to Rear-Admiral Sir Frederick Maitland, Naval Commander-inChief, 28 January 1839, no. 168, Correspondence Relative to Sinde: 1836-1843, 168. Lakshmi Subramanian, 'Banias and the British: The Role of Indigenous Credit in the process of Imperial Expansion in Western India in the Second Half of the Eighteenth Century', in Modern Asian Studies, Vol. 21, no. 3, 1987, 473-476. 
benefited from the conquest of Sindh by the British; this is largely because the development of the port of Karachi by the British increased their trade and therefore their profits. ${ }^{110}$ We can presume, therefore, that most members of the mercantile class in Sindh had reasons to be in favour of Sindh's annexation by the British. Naomal however, as well as profiting financially from his connections with the British, had another reason for supporting them. He had family and personal grievances against the Talpur Meers and he wanted to take revenge on them by conniving in their downfall. This detail has been provided by Sir Evan Lames in the preface to his published autobiography. There he wrote of conflict, sometimes violent, between Naomal's father and the Muslims of Karachi; the Talpurs had taken the side of the Karachi Muslims and tyrannised his father. From that time Naomal's family had been against the Talpurs. ${ }^{111}$

A letter dated 24 January 1839 from John Keane, commander of the Bombay Cavalry, to Hary Fane, the commander of the Bengal Cavalry, reveals the importance that the British gave to Sindh for a successful Afghan Campaign. ${ }^{112}$ Keane noted in his letter that up until now the British always considered Sindh of 'secondary consideration' or a 'light affair'. ${ }^{113}$ However with the strong reaction of the Hyderabad government against the march of the British Army of the Indus through Sindh, Kane realised that Hyderabad had become a site of strategic importance for the British. The Bengal column of the Army of the Indus marched from Ferozpore through Bahawalpur and reached Bhakkur by 26 January $1839 .{ }^{114}$ Kane believed that the 'barbarians' of Sindh had to be dealt with first before proceeding on to Afghanistan. ${ }^{115}$ As noted earlier in this chapter, the Meers are often David Cheesman, “"The Omnipresent Bania:” Rural Moneylenders in Nineteenth-Century Sind', Modern Asian Studies, Vol. 16, no. 3, 1982, 448.

111 Naomal Hotchand, A Forgotten Chapter of India History as Described in the Memoir of Seth Naomal Hotchand, xxx.

112 Sir John Keane to Sir Henry Fane, 24 January 1839, no. 160, Correspondence Relative to Sinde: 1836-1843, 160.

113 Ibid.

114 Sir John Keane to the Governor-General, 26 January 1839, no. 142, Correspondence Relative to Sinde: 1836-1843, 162.

115 Ibid.
} 
referred to as 'barbarians' in British sources from this time onwards; it was a label used to justify the annexation of Sindh.

Pottinger instructed the Bombay cavalry under John Keane to occupy Karachi. ${ }^{116}$ The Baluchi soldiers were ready to resist the British push into Sindh that the treaty of 1839 represented, but Noor Muhammad was intimidated when the Army of the Indus came closer to Hyderabad and when a regiment of the Bengal cavalry marched from Rohri towards Hyderabad. On 1 February 1839, Sir John Keane wrote to the Governor- General that he would encamp at Kotree, on the right bank of the Indus and adjacent to Hyderabad. Pottinger was now to force the Meer to pay to the British the money they agreed to pay Shah Shuja, as specified in one of the clauses of the 1839 treaty. ${ }^{117}$

Keane hoped that Karachi would be taken by British forces by 2 February and that he would proceed from there to Shikarpur. ${ }^{118}$ A supplementary British force of three thousand men under Brigadier Valiant and the battleship Wellesley arrived at Maonra, near Karachi, and took that township by storm. Rear Admiral Fredrick Maitland asked the Meers holding the fort of Manora to surrender. The Meer refused and fired at the Wellesley. The Meers, however, were quickly overpowered and the fort of Manora fell to the British on 4 February $1839 .^{119}$

The British intended to occupy Karachi until the war in Afghanistan ended. The fort of Karachi was to be a depot for storing provisions for the Army of the Indus. Auckland was confident that the military occupation of Karachi could be sustained without further military backup and that the British force could now march to Qandahar to install Shuja ul-Mulk on the throne. He declared that he did not intend to extend British control in Sindh any further and did not want to give the impression that he intended to make Afghanistan a part of the British Indian Empire.

$116 \quad$ Lambrick, Sir Charles Napier and Sindh, 39.

117 From Sir John Keane to the Governor-General, 1 February 1839, Number 148, Correspondence Relative to Sinde: 1836-184,171.

118 Ibid.

119 Talpur, The Talpur Rule in Sindh, p. 76; From Resident in Sinde to J.R. Colvin, Esq., Private Secretary to the Governor- General, 4 February 1839, no.151, Correspondence Relative to Sinde: 1836-1843, 172. 
Furthermore, on the march to Qandhar, he intended to ally with all chieftains who were friendly to the British, but those who hindered the British army's progress would be met with force. ${ }^{120}$

The Meers of Sindh now acceded to the terms demanded by the British and, on 9 February1839, paid ten lakhs rupees to Pottinger for forwarding to Shuja ulMulk. ${ }^{121}$ The fort of Manora in Karachi was, for the time being, to be held by the British. Because Karachi was now held by the British (and up until the Afghan war), articles thirteen, fourteen and fifteen became redundant and were deleted from the 1839 treaty. On 11 March 1839, Pottinger presented the Meers with a revised treaty, consisting of fourteen articles. According to this document, the British and Meers Noor Muhammad Khan, Meer Naser Muhammad Khan, Meer Meer Muhammed Khan and Meer Sobdar Khan were to be 'lasting' friends and allies with a 'unity of interest'. Sindh was also to maintain a British force, the strength of which was to be decided by the Governor-General but should not exceed five thousand soldiers; this military unit was to be stationed in Thatta on the west side of the river Indus. ${ }^{122}$

To meet the cost of maintaining the British militia, the revised treaty required that Meer Noor Muhammad, Meer Nasir Muhammad Khan and Meer Muhammad Khan each pay to the British one lakh of rupees in either Company currency or in the Timuri currency known as Bakkaroo. Meer Sobdar was exempted from this payment. Another treaty clause specified that the Meers were to be given British protection from any foreign encroachment. The four Meers with whom the treaty was signed were to remain the 'absolute rulers' of the separate territory under them and the British were not to interfere in the jurisdiction of their territory nor would they receive or adjudicate any complaints made against them. The four Meers, according

\footnotetext{
120 From the Governor-General to Lieutenant- General Sir John Keane, 10 February 1839, no. 160, Correspondence Relative to Sinde: 1836-1843,173-174.

121 From the Resident in Sinde to the Envoy with Shah Shooja, 10 February 1839, no. 161, Correspondence Relative to Sinde: 1836-1843, 179.

122 C.U. Aitchison, A Collection of Treaties, Engagements and Sunnads Relating to India and Neighbouring Countries, V. II, ( Calcutta: O.T. Cutter, 1865), 57.
} 
to the treaty, were to seek the mediation of the British resident when there were disagreements or disputes among them. ${ }^{123}$

The revised treaty also specified measures for the management of disputes among people subject to the authority of the Meers. If the Meers themselves did not resolve a dispute, or failed to win compliance from their subject, the case could be referred to the Governor-General who, in turn, could ask the Resident to mediate the matter. The provision regarding dealing with any foreign power was same as the previous draft treaty. The Meers were now to cooperate with the British in matters relating to defence and security, but they were in a subordinate position, and obliged to provide the British authorities with an army of three thousand troops, both cavalry and infantry, when the need arose. This army was to be under the command of the British, and it would operate outside Sindh's borders; the cost would be covered by the British government. ${ }^{124}$

The treaty would require that the Company currency be used in Sindh, replacing the use of the Timuree Rupees; once a mint was established in Sindh, the Meers were to be paid seigniorage for coining the currency; a mint was established after the end of the 1839 - 42 war in Afghanistan The revised treaty reiterated the requirement of the original draft treaty-that the transit toll on trade boats transporting goods from the sea to Sindh's northern border was to be abolished. Any goods, however, that had been shipped along the Indus and sold in Hyderabad were liable to a sales tax except if it was sold in the British camp in Sindh. The merchants were allowed to keep goods at Gorabaree at the mouth of the Indus, until the river became navigable. However if any merchant decided to sell the merchandise at Gorabaree, or at any other place, then they were liable to pay sales tax on the goods. Goods exchanges between British merchants and purchasers were, however, exempted from this tax. ${ }^{125}$

C.U. Aitchison, A Collection of Treaties, Engagements and Sunnads Relating to India and Neighbouring Countries, V. II, (Calcutta: O.T. Cutter, 1865), 57. Ibid., 58. Ibid.,59-60. 
Meer Rustam of Khairpur, albeit with some reluctance, had handed over the fortress of Bhakkar to the British when they had encamped near it. ${ }^{126}$ Bhakkar thus became a British colony on 29 January 1839. Eastwick wondered why Meer Rustam had so easily acceded to the British demand that Bhakkar be handed over. ${ }^{127} \mathrm{~A}$ possible reason for his friendly disposition towards the British was his conflict with Meer Ali Murad, the other Meer of Khairpur; Meer Ali Murad had also helped the movement of British troops through his territory. ${ }^{128}$ The Army of the Indus, after crossing the Indus, reached the Kach Gandava region where water and supplies were lacking. Here the army was much harassed by the Baluchi tribes and suffered raids on their cantonment. The Army was now appreciating that its difficulties in Sindh were the result of inadequate preparation in the form of surveys of the terrain through which the Afghan expedition was to pass and careful assessment of supply needs. The army, already depleted in strength, pushed on; it passed through Quetta and reached Kandahar on 24 April 1839. ${ }^{129}$ At Qandahar, Shuja ul-Mulk was welcomed by his tribesmen. Khun Dil Khan; his brother, who had been governor fled to Girishk. ${ }^{130}$ On 27 June, the Army of the Indus reached the Afghan city of Ghazni; it fell after a hand to hand fight with Afghan forces. Dost Muhammad then sent his brother with a proposal of peace to the British envoy, William Hay Macnaghten. Macnaghten offered Dost the opportunity to go into exile in British India, an offer that Dost did not accept. Instead, he fled to Jalalabad. The army chased after him, and he fled further to Bamian. Ultimately his family surrendered to the British and accepted the offer of exile in India. Shuja ul-Mulk was installed on the throne of Kabul. It turned out, however, that he was unable on his own to hold Kabul against the recalcitrant tribes of Afghanistan. And so a British force was stationed at Kabul to enable Shah Shuja to rule securely there. ${ }^{131}$

From Willoughby to Lord Auckland, 29 January 1839, camp at Roree, Secret Consultations, 22 May 1839, no.3, NAI.

Eastwick, A Glance at Sind before Napier, 60.

Ibid, 60.

MacMunn, The Lure of the Indus, 56.

Ibid.,56.

Talpur, The Talpur Rule in Sindh, 77. 
To facilitate Britain's prosecution of the Anglo-Afghan war, Sindh was also required to allow the functioning of a parallel British military station; it supported the Army of the Indus by maintaining cantonments and markets in Sindh. Hyderabad and Sukkur were the headquarters for the British political agents whose responsibility it was to ensure that Sindh observed the terms of the 1839 treaty, and to mediate disputes among the Meers. Very clearly, therefore, the first AngloAfghan war was a crucial step in the process by which the British annexed the state of Sindh. Through the march of the Army of the Indus on Afghanistan, political and military institutions in Sindh were made subservient to the British, and strategic places such as Shikarpur, Karachi and Bhakkar became British military stations.

During this time the Meers had a supporter among the British authorities. Captain James Outram was the new Political Agent of Lower Sindh, appointed in January 1840 to follow Pottinger. He spoke out against the injustice done to the Meers by Lord Auckland. He pointed out that the Meers had made no commercial gains through the 1839 treaty. A consequence of the establishment of a British garrison in Sindh was a rise in the prices of commodities. Afghan merchants flagrantly used a private pass obtained from an English officer as a free pass, a pass through which taxes could be evaded; tax evasions such as these reduced the revenue collected by the Sindh state. ${ }^{132}$ Outram himself detected one such fraud by an Afghan merchant who was trying to evade sales tax on 'a camel-load of pepper' on his way to Sukkur. ${ }^{133}$ Outram advised the Assistant Political Agent at Karachi that the British were obliged to stop these frauds. ${ }^{134}$

Outram also acted as a mediator among the fractious Meers of Sindh and between the Meers and the British. On 12 August 1840 Outram wrote to the Government of India that there appeared about an apparent boundary dispute between the Hyderabad Meers and the Meers of Meerpur; he proposed to settle the

132 Sir Charles Napier, p. 42, From the Political Agent in Lower Sinde to the Secretary to the Government of India, 6 April, 1840, no. 252, Correspondence Relative to Sinde: 1836-1843, 271. 1840, no. 270, Correspondence Relative to Sinde: 1836-1843, 293. Ibid. 
dispute through the mediation of Lieutenant Whitelock. ${ }^{135}$ Meer Sher Muhammad, Outram reported, relied on the British to shore up his power; he had written to the Native Agent at Hyderabad to say that he was seeking British support in the Hyderabad-Meerpur dispute. ${ }^{136}$ The power that British protection gave to Meerpur's neighbours, the Meers of Hyderabad and Khairpur, is likely to be the reason why Sher Muhammad also sought an alliance with the British. Outram told Whitelock that he would ask the Sindhi merchant Seth Naomal to accompany him; Naomal's local knowledge would be invaluable. From Outram's point of view the 'devotion' that Noamal had always shown to the British made him particularly trustworthy. ${ }^{137}$ Whitelock was also asked by Outram to discretely find out how much property was owned by Meer Sher Muhammad; he should get Naomal to find this out without raising the Meer's suspicions. ${ }^{138}$ Information about Sher Muhammad's property holdings was needed to settle the dispute between him and the Meers of Hyderabad.

Late in November 1840, Noor Muhammad was reported to be severely ill and Outram sent a British doctor named Owen to treat him. ${ }^{139}$ The Meer, however, died on 5 December 1840. Outram observed that during the last phase of his life Meer Noor Muhammad had come to realise that intriguing against the British was futile, and that it was more sensible to support than to resist the British endeavours in Sindh. ${ }^{140}$ Before his death, Meer Noor Muhammad had nominated his son Hussain and his brother Meer Nasir Khan to serve as joint rulers of Hyderabad. After Noor Muhammad's death, his brother Meer Nasir Khan became the principal Meer.

\footnotetext{
135 From the Political Agent in Lower Sinde to the Secretary to the Government of India, 12 August 1840, no. 271, Correspondence Relative to Sinde: 1836-1843, 294.

136 From The Native Agent at Hyderabad to Meer Shere Mahomed Khan of Meerpore, No. 256, Correspondence Relative to Sinde: 1836-1843, 273.

137 The Political Agent in Lower Sinde to Lieutenant Whitelock, 13 January 1841, Correspondence Relative to Sinde, no., 295, 313.

138 The Political Agent in Lower Sinde to Lieutenant Whitelock, 13 January 1841, Correspondence Relative to Sinde: 1836-1843, 312-313.

139 The source does not specify his full name. From the Political Agent in Lower Sinde to the Secretary to the Government of India, 6 December 1840; From The Native Agent at Hyderabad to Meer Shere Mahomed Khan of Meerpore, no. 256, Correspondence Relative to Sinde: 1836-1843, 300.

140 From the Political Agent in Lower Sinde to the Secretary to the Government of India, 6 December 1840; From The Native Agent at Hyderabad to Meer Shere Mahomed Khan of Meerpore, no. 256, Correspondence Relative to Sinde: 1836-1843, 300.
} 
Hussain Ali's right to succession, however, was challenged by his brother Shahdad. Outram mediated this dispute, and managed to peacefully divide the dominion of Noor Muhammad between his sons Hussain Ali Khan and Meer Shahdad. ${ }^{141}$ Thenceforth Meer Nasir Khan, his nephew Meer Shahdad and cousin Meer Mahommad each maintained separate courts in Hyderabad; another separate court was maintained by Meer Sobdar, in association with Meer Hussain Ali. ${ }^{142}$

In Khairpur differences arose between Meers Murad Ali and Rustam Ali. Meer Murad Ali had his own agent in the British Camp and his allegiance was to the British. He appealed to Bell, the British political agent at Khairpur, to resolve territorial disputes over some villages between himself and his nephew Nasir Khan; Nasir Khan was backed by Meer Rustam Ali. Ross Bell, after investigating the matter, ruled in favour of Meer Murad Ali and rebuked Meer Rustam. Bell did this despite Ali Murad's questionable conduct and intrigues against Meer Rustam. Here again we see application of the divide and rule strategy in Sindh by a British official. ${ }^{143}$ Meer Rustam, who was anxious to win favour with the British, threatened to send his envoy to complain about Ross Bell to the Governor- General. Bell, however, died on 31 July 1841, and Major Outram was appointed to serve as the British agent at Khairpur. Meer Rustam's position improved after this. ${ }^{144}$

\section{Aftermath of the First Anglo-Afghan War}

Sindh was conquered soon after the first Anglo-Afghan war (1838-1842) and therefore the war has been considered as part of the process of the annexation. However the Afghan War only determined the sequence of events, not the annexation itself. The British had already entrenched themselves in the political system of Sindh by the late 1830 s and annexation was only a matter of time.

Towards the end of Lord Auckland's tenure as Governor-General (1836-1842), the British forces in Afghanistan were suffering some losses, and this was largely due to

Talpur, The Talpur Rule in Sindh, p. 78: Lambrick, Sir Charles Napier and Sindh, 49. Lambrick, Sir Charles Napier and Sindh, 49

Ibid., 46

Ibid., 44. 
the riots in Kabul. Shuja was unable to deal with revolts against him by the Marris, Barkazais, Brahui and Kakar tribes.

In 1839 William Hay Macnaghten had been sent to serve as the GovernorGeneral's representative at the court of Shah Shuja for the purpose of bolstering Shuja's authority in Kabul. His use of British resources for this purpose and his interference in the internal affairs of the state led to a state of diarchy in Kabul; Shuja and the British seemed to be running parallel governments there. The British intervention in Kabul politics was even resented by Shuja. ${ }^{145}$ His regime was becoming unpopular and internal revolts against Anglo-Sadozai rule were increasing. The maintenance of British control in Afghanistan was at the huge cost of two million pounds per year; this was more than the Company's income from the tea and opium trade in South Asia. ${ }^{146}$ The causes of the internal uprisings against Shuja were local and tribal in nature; they were also a reaction against the declining economic situation in Kabul, where the price of grain and other basic commodities rose by five hundred percent in $1841 .{ }^{147}$

The new Tory government in London under Robert Peel opposed further financing of the Afghan expedition. ${ }^{148}$ Macnaghten had to cut subsidies paid to the the Ghilzais in exchange for their protection of the passes and roadways. And he decided to send part of the British garrison in Kabul back to India. On 9 October 1841, a thousand members of Brigadier Robert Sale's brigade en route from Kabul to Jalalabad were attacked by Afghans and suffered heavy casualties. ${ }^{149}$ Afghan insurgency against the British began in Kabul as well, with Afghans murdering any British or Indian they came across. Alexander Burnes was to have replaced Macnaghten, who had been appointed Governor of Bombay, but both men soon fell

\footnotetext{
145 Louis Dupree, 'The First Anglo-Afghan War and the British Retreat of 1842: the Functions of History and Folklore', East and West, Vol. 26, No. 3/ 4 (September- December 1976),509, William Dalrymple, The Return of a King: the Battle for Afghanistan (London: Blooms, 2012), 172.

146 Dalrymple, The Return of a King, 192, 193.

147 M.E. Yapp, 'Disturbances in Eastern Afghanistan, 1839-1842' Bulletin of the School of Oriental and African Studies, Vol. 25, No. 1/3 (1962), 1839-1842, 523, Dalrymple, The Return of a King, 199.

148 Dalrymple, The Return of a King, 198

149 Dalrymple, The Return of a King, 202, 203.
} 
victim of the rising political chaos and lawlessness in Kabul. On 2 November an armed mob of Afghans pillaged Captain Hugh Johnson's treasury, setting it and Burnes' house alight, and killing Burnes in the process ${ }^{150}$. The British cantonment in Bala Hisar, where Shuja's fort was situated, was also abandoned. Sale's brigade reached Jalalabad on 12 November and occupied the city. The next day a band of Afghans from the Ghilzai and Shinwari tribes surrounded and began attacking the British brigade which, by now, needed fresh supplies of men and provisions. ${ }^{151}$

Akbar Khan, Dost Muhammad's son, left Bamiyan in late 1841 and soon emerged as the leader of the Afghan resistance. Akbar blocked the British cantonment at Bibi Mahru, cutting off its supplies. When he reached Kabul in December 1841 he invited Macnaghten to talks. ${ }^{152}$ The two agreed that the British would withdraw from Afghanistan on 14 December and Dost Muhammad was to be allowed to return to Kabul from his exile in Ludhiana. The British were to leave behind a hostage in Afghanistan, and the hostage was to remain there until Dost Muhammad's return to Kabul. In return the British were to be given safe passage back to India and, instead of a cash payment, supplied with rations.

Shuja resented this deal with the British and expelled Akbar Khan's forces at Bala Hisar. In the freezing winter month of December, many Army of the Indus soldiers perished for want of adequate rations. During the retreat from Afghanistan, Macnaghten received only a handful of provisions for his army. And Akbar Khan, to take advantage of the vulnerability of the British, demanded more payment for the provision of rations. At this point Macnaghten wanted to go back to Bala Hisar and fight the Afghans. The chance for this came when he received an offer of an alliance against Akbar from a Barkazai Afghan leader, Nawab Zaman Khan. Macnaghten plotted the assassination of Akbar Khan, a scheme that became known to Akbar.

\footnotetext{
150 Dalrymple, The Return of a King. 207-217, Dupree, 'The First Anglo-Afghan War', 510

$151 \quad$ Dalrymple, The Return of a King, 206.

152 Dalrymple, The Return of a King, 233-235.
} 
Akbar's response was to invite Macnaghten to a meeting on 23 December; Macnaghten complied and was killed by Akbar. ${ }^{153}$

The British army began retreating from Kabul on 6 January 1842. The cold winter weather and attacks by Afghan tribes made the retreat difficult, and it ended in the massacre of the British army. ${ }^{154}$ The routing of the Company's army lowered the morale of the British. The defeat in Afghanistan was followed little more than eighteen months later by the annexation of Sindh at the hand of the British commander Charles Napier

One of the reasons for the failure of the British in the Afghan war was their inability to provide an effective leader for the expedition. Sir William Macnaghten was not able to assert his authority over the British cantonments beyond the north of the Indus. The British officers in charge of the Army of the Indus at Kandahar and Quetta were virtually independent of Macnaghten's authority, and the British political agent in Upper Sindh refused to recognise his authority. The separate garrisons of the Army of the Indus did not coordinate with each other. The various military and civil officers had different approaches in dealing with the local leaders in Afghanistan. General Nott, a military Commander in the first Anglo-Afghan war, was in favour of communicating with them in writing. In upper Sindh the British resident and general was more inclined to use violent means of subjugating the Afghans. ${ }^{155}$

William Dalrymple has made a close analysis of the first Anglo-Afghan war. He points out that even before the war in Afghanistan was over, Lord Auckland, an empire builder as much as other agents of the British government at the time, had begun preparations for war in China. In 1840 he withdrew the Bombay Army from Kabul and diverted a significant quantity of British resources in India to south China to fight the first of two Anglo-Chinese Wars (commonly known as the 'Opium Wars'). Dalrymple further suggests that Macnaghten was left with insufficient troops 
and resources to consolidate the rule of Shah Shuja in Afghanistan. ${ }^{156}$ Even at the time, senior British officers were critical of the way in which the 1839-42 war was prosecuted. Charles Napier, who became governor of Sindh in 1843, blamed Auckland for an 'unjust' war in Afghanistan. ${ }^{157}$ And the war did damage in Sindh as well. For the sake of British ambitions in Afghanistan, Sindh had to lose its political autonomy. William Napier, Charles Napier's brother, wrote in 1857 that Auckland facilitated the invasion of Afghanistan by imposing an unfair treaty on Sindh that was

... signed under the guns of Sir John Keane's army; it [the treaty] rendered the Indus free for all the fluvial nations, and gave the British paramount authority in Scinde with possession of Kurrachee, Sukur, Nukkur, Roree, Shikarpur, and a chain of posts by Dadur to the Bolan pass. For more than three years it had been in force, and Lord Ellenborough's orders were expressed as to observance of its stipulations. This was vital for the British interests; for the Ameers, fretting under the yoke, were exciting the mountain tribes to war, and preparing for it themselves, being encouraged by the Kabul disaster. $^{158}$

The Talpur Meers, however, believed that the British garrison in Sindh would leave soon after the British operation in Afghanistan was over. As noted earlier, Meer Sobdar was a favourite of the British, and he knew that his interests were best served by cooperating with the British. Similarly in Khairpur, Meer Rustam had sided with the British, but he was like a puppet in the hands of his minister Fateh Muhammad Ghori who was backed by his nephew, Meer Nasir Khan of Hyderabad. At the time, Nasir Khan wanted to maintain his position as a principal Meer but he thought seeking British help for this was not a solution. He seemed to believe that the British were there only until the end of the Afghan war, which was not going well for them. In fact, he was suspected of plotting against the British. This suspicion

156 William Dalrymple, The Return of a King, 165.

157 Lieut.-Gen.William Napier, The Life and Opinions of General Sir Charles James Napier, 158 G.C.B (Cambridge: Cambridge University Press, 2011; first published in 1857), V. 2, 161. Ibid., 197. 
was triggered by two letters passed on to Outram by Clerk, the Resident in Lahore. One letter looked to have been written by Meer Nasir Khan of Hyderabad to Diwan Sawan Mul of Lahore, and the other by Meer Rustam to Sher Singh of Lahore; both letters proposed alliances against the British. Lord Ellenborough who succeeded Lord Auckland as Governor-General on 28 February 1842, and who was preoccupied with the disaster in Afghanistan, asked Outram to check the authenticity of the letters because they had been suspected to be forged by Meer Ali Murad, the enemy of Meer Rustam. ${ }^{159}$

Outram told the new Governor-General that he would investigate the matter. Ellenborough was determined to punish the Talpur Meer if found guilty of the intrigues. ${ }^{160}$ The setbacks in Afghanistan had sullied the image of an all-powerful British Empire and Ellenborough wanted to restore that image. He therefore wrote on 1 October 1842:

I was deeply sensible of the impression which the reverses at Cabool had produced upon the minds of native princes, of the native population, and of our own troops. I knew that all that had taken place since and all I had said and done, although it must have much diminished, could not have obliterated that impression, and restore to our Government and to our army, the place they had before held in the opinion of India. ${ }^{161}$

The Duke of Wellington, in a letter to Ellenborough, expressed the same concern: 'It is impossible that that fact [defeat in the Afghan war] should not produce a moral effect injurious to British influence and power throughout the whole extent of Asia. ${ }^{162}$ Ellenborough wanted to withdraw the British army from Afghanistan but he also wanted to maintain the existing British garrisons in Sindh (except in Shikarpur) in return for the payment which the 1839 treaty stipulated the Meers had to remit. This and a few successful wars in India were needed to restore Britain's

\footnotetext{
$159 \quad$ Eastwick, A Glance at Sind before Napier, 259.

160 Lambrick, Sir Charles Napier and Sindh, 51-53.

161 Colchester, History of Indian Administration under Lord Ellenborough, 110.

162 Ibid., 110.
} 
image as an all-conquering power. Ellenborough, however, knew that the garrisons could not stay in Sindh without the Meers' concurrence; as he wrote: 'We could hardly have justified our remaining at Karachee, we could not have justified our remaining at Bukkur, after the termination of the war in Afghanistan, without a new treaty. $^{, 163}$

So Lord Ellenborough wanted a new treaty with the Meers in order to have British garrisons remain in Sindh. The Sindh question would have to be decided by the Home Government but, as far as Ellenborough was concerned, Karachi, Bukkur and Sukkur were to remain in British hands in the meantime. ${ }^{164}$ Also, Ellenborough wanted to reward the Nawab of Bahawalpur's loyalty with a land grant. Sabzalkot, a frontier post, had been taken from Bahawalpur by the first generation of Talpurs it was now part of the territory controlled by Meer Nasir Khan of Hyderabad. To punish Nasir Khan and reward the Nawab of Bahawalpur, Ellenborough wanted to transfer Sabzalkot to Bahawalpur. The intrigues uncovered by Outram's investigations could give him the pretext to do this. This matter had still not been resolved when, in July 1842, the appointment of Sir Charles Napier as commander of the British troops in Sindh was announced. ${ }^{165}$ Ellenborough placed Colonel Outram, who was lenient towards the Meers, under Sir Charles Napier; he knew that Napier would support his ambitious policy in relation to Britain's role in Sindh. Napier arrived in Sindh on 10September 1842, ${ }^{166}$ and Ellenborough instructed Outram to hand over to him the results of his investigation into the intrigues among the Meers. This decision of Ellenborough's was to work against the Meers, because Napier proved to be an ambitious man, looking for fame and glory as a military commander; he became a key protagonist in the annexation of Sindh. William Napier, writing in 1857 about Charles Napier, said that he committed to 'augmenting the glory of England by his courage and genius. ${ }^{167}$ On 23 December 1841 Macnaghten was

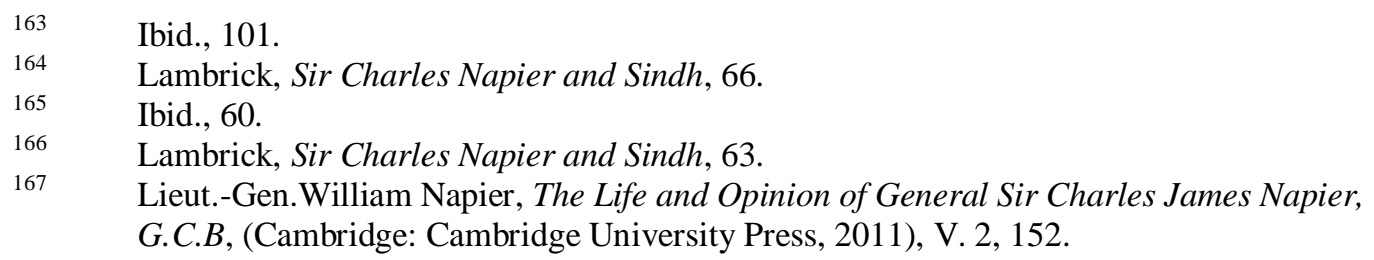


killed in Afghanistan by supporters of Dost Muhammad; Napier refused to describe the assassins as 'rebels'. ${ }^{168} \mathrm{He}$ asserted that the British had no right in the first place to overthrow Dost Muhammad as ruler of Kabul. The 'disgrace' that the British had suffered in Kabul was, according to Napier, due to Auckland's wrong strategy. Nevertheless, Napier's concern for the 'honour and image' of England and his dreams of the glory he could bask in if he repaired the 'tarnished image' of England after the Afghan war, made him glad to accept the position of the commander of the British troops. On 3 February 1842, before he was appointed to Sindh, Napier observed that the 'rebellion' or turbulence in Kabul showed that the 'Scindians are said to be growing more hostile, if so I shall certainly be sent [there]. I am ready., 169 Under Napier's leadership, the British had retaken Kabul and laid it waste by the end of September 1842. The Afghan War had ended. ${ }^{170}$ Thus the 'tarnished image' of the British due to losses in Afghanistan had now been repaired. Even so, Napier still wanted to annex Sindh.

While the British were busy withdrawing their army from Afghanistan and maintaining their garrisons in Sindh, the Meers were carrying on their own squabbles over boundary questions. Meer Nasir Khan occupied certain villages in territory controlled by Meer Ali Murad. The latter therefore appealed to the British to help him get back his territory. There followed a skirmish between the two contending Meers in which one man on either side was killed. ${ }^{171}$ In another dispute Meer Ali Murad wrote to Captain E.I. Brown, the assistant political agent at Sukkur, alleging that Meer Nasir Khan had burned his villages and killed his sepoys; he appealed to Captain Brown to stop the strife. He also claimed that Fateh Muhammad Ghori, the waqil (envoy) of Meer Rustam ofKhairpur, was plotting to harm him, making a compact with Meer Nasir Khan, Meer Ali Murad and Meer Muhammad Hussain to

Ibid., 161.

Ibid., 161.

Lambrick, Sir Charles Napier and Sind, 66-67.

From the Assistant Political Agent in Charge to T.H Haddock, Secretary to the Government of India with the Governor-General, Allahabad, 12 July 1842, Secret Consultations, 3 August1842, no.39-40, NAI. 
cooperate in forceful action against him. ${ }^{172}$ Captain Brown suggested to Outram that he reply to Meer Ali Murad as he thought proper. Meer Rustam, being the principal Meer was also asked to intervene to solve the dispute within the family. ${ }^{173}$ Meer Ali Murad, however, marched with his forces to Khanpore, near Meer Nasir Khan's fort, and started firing guns with blank ammunition. Meer Rustam's response was to write saying that he was willing to settle the dispute among the family members. Meer Ali Murad, however, could not wait for Meer Rustam's mediation. ${ }^{174} \mathrm{~A}$ conflict erupted at Naunihar between Meer Ali Murad Khan and Meer Rustam on one side and Meer Nasir Khan, on the other; Ali Murad won this battle. As a consequence, the villages for which he was fighting were restored to Ali Murad. ${ }^{175}$

After this Ali Murad made further attempts to get closer to the British because he wanted to challenge the will of Meer Sohrab, who had died in 1830. The will divided Meer Sohrab's territory between his sons - Meer Rustam, Meer Mubarak and Meer Ali Murad. Meer Mubarak died in 1839 and Ali Murad now aspired to displace Meer Rustam and become the chief Meer of Sindh. Predictably, Meer Rustam resisted, and made clear that he expected his eldest son to succeed him as chief Meer of Khairpur. Now, however, Meer Rustam came under the scrutiny of British officials. They learned that a secret correspondence between the Meer and the ruler of Lahore was an act of hostility towards the British. ${ }^{176}$

Another act of hostility towards the British were the twenty-four charges against the Meers, of which eighteen were against Meer Nasir Khan, and twelve of these were related to Article XI of the treaty of 1839 which required that the Meers no longer collect tolls on goods transported on the Indus. There were also charges against Meer Rustam regarding the defiance of the treaty signed with the British. During post annexation investigations we find Captain William Joseph Eastwick From Meer Ali Murad to Captain Brown,, Assistant Political agent in Charge of Office of Political Agent, 7 September 1842, NAI. From Captain E. I. Brown, Assistant Political Agent in Charge of Office of Political Agent to Meer Ali Moorad, Sukkur, 9 September 1842, NAI. Ibid. Ibid. Napier, The Life and Opinions, 228-243.
} 
(1808-1889), Director of the East India Company, arguing that there was still no evidence to support the accusations and that the Meer had not been given an opportunity to defend himself. ${ }^{177}$ E. B. Eastwick, writing in 1849 , judged that Meer Rustam had suffered an injustice at the hands of the British, a consequence of allowing ambitious soldiers like Sir Charles Napier to pursue a hard line policy against the native princes. ${ }^{178}$ Napier pointed out other charges against the Meers. One was that they unlawfully tried to stop Naomal from selling supplies to the British. This was a breach of articles twelve and thirteen of the 1839 treaty, according to which goods were to be sold duty free in the British cantonment. ${ }^{179}$ The Meers, for their part, considered that the British were breaching article five of the treaty when they agitated against the Meers' halting of war supplies. ${ }^{180}$ In October 1842 Meer Nasir Khan wrote to leaders of the Baluch mountain tribe to urge that they rebel against the British and expel them from Sindh. Napier considered that this was a breach of the 1839 treaty article that required the Meers not to correspond with any other power or chief without the permission of the British. ${ }^{181}$

British authorities judged that the 1839 treaty had been so frequently breached that the Meers had to be forced to accept a new treaty. In October 1842 Napier suggested to Lord Ellenborough that he should ask Meer Nasir Khan to maintain a British subsidiary force at his court. He told Ellenborough that the Meers' government was inhumane and the British should seize either Karachi or the whole of Sindh. ${ }^{182}$ Napier wrote that Outram agreed with him, and added: 'I like him much, for that reason probably, for I confess not to like those who differ in opinion with me. ${ }^{183}$ Here we have further evidence of Napier's arrogance and imperial ambitions. Nevertheless, as we will soon see, there arose a difference between Outram and

William Joseph Eastwick, Speeches of Captain William Eastwick on the case of the Ameers of Sinde at a special court held at the India House on Friday 26th January 1844 (London: James Ridsway, 1844), 22. Eastwick, A Glance at Sindh before Napier, 68-71. Napier, The Life and Opinions, 208.

Ibid., 207.

Ibid., 219.

Ibid., 220.

Ibid., 222. 
Napier on the issue of whether Sindh should be annexed; Outram eventually began to realise that Napier's treatment of the Meers was unduly harsh.

Outram wanted to retain Shikarpur and he gave some other suggestions to Napier about the way the new treaty should be negotiated with the Meers. Napier wanted to secure Shikarpur for its commercial advantages. From Shikarpur merchandise could be sent upto Sukkur and from there up the river Indus. And by means of a land route from Larkana through Shikarpur, goods could reach Karachi. Another advantage that Napier saw in holding Shikarpur was that it was inhabited by rich bankers and Hindu traders; these people could work as intermediaries between the Muslims and the British and help bring them under British rule. ${ }^{184}$ The Governor-General, however, in a letter to Napier dated 17 October 1842, rejected the idea of holding on to Shikarpur because it would stretch the British regime's military resources. Also Ellenborough was interested in trade on the western section of the Indus, the region through which the river connected Firozpur to the sea. ${ }^{185}$ During this time the British also learned that, with the encouragement of the Meers of Hyderabad, both Meer Nasir Khan and Meer Ali Murad had joined forces against the British. $^{186}$

On 4 November 1842 Lord Ellenborough ordered to dispatch the draft treaty to the Hyderabad Meers. According to this draft, Sukkur, Bukkur, Karachi and Rohri were to be ceded by the Meers to the British in lieu of tribute paid by the Meers. In addition, the coining of money by the Meers was forbidden. In order to have a uniform currency throughout India, only the British could mint and issue coins. The coins were to bear the head of Queen Victoria on one side; what went on the other side could be freely chosen by the Meers. ${ }^{187}$ Once the new currency was coined, the Meers had to deliver to the British government a quantity of silver equal to the value of the currency coined. Within four months of the approval of the bill for coining of the new currency, the Meers were to be repaid its cost.

\footnotetext{
184 Ibid., 222.

185 Lambrick, Sir Charles Napier and Sindh, 75.

$186 \quad$ Napier, The Life and Opinion, 222.

187 Lambrick, Sir Charles Napier and Sindh,75.
} 
The draft treaty gave to the British government the right to fell trees within one hundred yards of each side of the Indus, and to use the timber for boat-building. However if the Meers wanted to propose more convenient places for tree felling, British officials could harvest timber in those places for a price to be fixed by the Meers. $^{188}$

The new treaty also stipulated that the Meers were to cede Karachi and Thatta to the British Government in perpetuity. British jurisdiction was to be established within the Karachi-Thatta region and along the route in between these regions. Subzulkote and the region between the contemporary boundary of Bahawalpur and Roree were to be ceded to the Daudputra Nawab of Bahawalpur, who was allied with the British. Meer Sobdar, another loyal ally of the British, was to be compensated for the loss he incurred by ceding Karachi to the British Government. The compensation was territory that yielded revenue of fifty thousand rupees annually. Sir Charles Napier would appoint a commissioner who would allot the land to Meer Sobdar after canvassing the opinion of the other Meers. With the exception of Meer Sobdar, the value of the land ceded by the Meers to the British Government was to have a value equal to the tribute they were required to make to the British government. According to the treaty's eleventh clause, if the land had less value than the tribute they owed, then the shortfall was to be paid in cash. ${ }^{189}$

The treaty consisted of ten articles in total. It was signed by the Meers of Khairpur and British authorities on the same day as the draft had been presented to the Meers - that is, on 4 November 1842. It stripped the Khairpur Meers of almost all their territorial possessions; they had to cede them to the ruler of Bahawalpur. The ceded territory included Bhoong Bhara, a third of Subzalkote, the villages of Chaonga, Dadoola, Gotkee and Maladee, and the region between the boundary of Bahawalpur and Roree. According to another treaty provision, Sukkur, Bhakkar and the island neighbouring those islands were to be ceded to the British Government. A commissioner was to be appointed by Sir Charles Napier; that commissioner would 
collect any surplus owed by the Hyderabad Meer, and the Meers of Khairpur were to be advised of this. ${ }^{190}$

The 1842 treaty stipulated that the Meers of Khairpur were to continue to observe the terms of the December 1838 treaty that guaranteed the British free use of the Indus as a transportation route. It also reiterated the 1839 treaty's requirement that the Hyderabad Meers no longer impose tolls on Indus River traffic, nor impose levies on goods unloaded at river ports. From 15 January 1845, only the Company coin was to be legal tender in Khairpur. For its part, the British government was to stop claiming tribute from Shuja; the same applied to the tribute once paid by the late Meer Mubarak Khan and his sons, and to Meer Nasir Khan. ${ }^{191}$

Napier claimed that the new treaty was designed to 'favour our Indian interest, by abolishing barbarism and ameliorating the condition of society, by obliging the Ameers to do, in compliance with those treaties, that which honourable civilized rulers would do of their own accord ${ }^{192}$ He said that the non-Baluchi Sindhis and the Hindu subjects of Sindh were Britain's allies. ${ }^{193}$ He said this in order to justify the annexation of Sindh. It is true that Sindh's Hindu Bania community favoured the British over the Meers. Examples include local Sindhis such as Naomal, whom Outram called 'friendly bania', ${ }^{194}$ and Mohan Lal, who worked as a British agent. However this does not seem to be true for all the Hindus of Sindh; they belonged to the Bhaibands caste and many of them were employed in administrative posts under the Meers.

Napier found important reasons for the British staying on in Sindh and consolidating their political control. The question, he said, was:

... Whether we shall abandon the interests of humanity and of the British government, in which case are one, and at once quit Scinde, or take

Ibid., 66-69.

Ibid., 69.

Napier, The Life and Opinion, 230.

Ibid., 230.

Hotchand and James, A Forgotten Chapter of India History as Described in the Memoir of Seth Naomal Hotchand, 12. 
advantage of existing treaties to maintain our camps permanently? But if we evacuate the country, future events will inevitably bring us back to the Indus. If we remain, our camps will quickly grow into towns, and the people within them will carry on a transit trade along the Indus... the more powerful government will, at no distant period, swallow up the weaker: would it not then be better, if it can be done with honesty. ${ }^{195}$

For Napier the positive consequences of annexation included toll-free trade along the Indus, the opening of the port of Karachi to British trade, reducing the threat posed by mountain tribes to Shikarpur, the development of Sukkur on the bank of Indus into a trade port, the construction of tracks along the banks of the Indus and the introduction of steam shipping along the Indus. While highlighting the commercial benefits for Britain that annexation would bring, Napier always reminded his countrymen of Britain's 'civilising mission': annexation by Britain would free Sindh from the tyrannical and barbaric rule of the Meers whose main concern, in his view, was their hunting preserves. ${ }^{196}$ Napier's negative view of the Meers influenced Ellenborough, who now asked to see the evidence of Meer Nasir's attempt to mobilise the mountain-dwelling Baluchis against the British and also the letter that Meer Rustam was said to have written to the ruler of Lahore. Major Outram had doubted that Meer Nasir and Meer Rustam actually wrote these letters, but Lieutenant Brown now declared them to be authentic. That decision worked in Meer Ali Murad's favour, and it also suited Napier, who wanted to provoke war in Sindh. ${ }^{197}$ The draft treaty was accepted by Meer Sobdar and Husain Ali Khan, both of whom expressed their willingness to cooperate with the British. The treaty required that Meer Husain Ali surrender Thatta; he did so regretfully but willingly. All the Meers of upper and lower Sindh agreed to the terms of the treaty. ${ }^{198}$ On 1 December 1842, one month after the treaty was signed, Napier annexed Meer Rustam's territory between Rohri and Sabzalkot, worth 6 lakhs and forty thousand rupees per 
annum. ${ }^{199}$ The next issue to be resolved related to leadership. Napier wanted to place the turban on Ali Murad and make him the principal Meer of Hyderabad, and he hoped to do this by persuading Meer Rustam to surrender to Meer Ali Murad. Meer Rustam however fled to Kot Diji. ${ }^{200}$ The other Talpur Meers of Khairpur also fled to Imamgargh, where Meer Rustam was now stationed. Napier, on 12 January 1843, set off to Imamgargh in pursuit. The Governor-General lost all confidence in Ali Murad when he let Meer Rustam and Fateh Muhammed Ghori escape. During the time that Napier was at Imamgargh, Meer Rustam sent his munshi to him to plead in his favour. But Meer Ali Murad's minister, who was also in Imamgargh, won over the munshi.Very shortly, another anti-British letter carrying Meer Rustam's signature appeared. The letter was a forgery. Its aim was to further sideline Meer Rustam. ${ }^{201}$

Outram was assigned the task of negotiating the treaty with the Meers of Hyderabad. ${ }^{202}$ His position as the British agent at Khairpur required that he champion the treaty, but he knew that its terms were unjust; he described them as 'tyrannical-positive robbery. ${ }^{203}$ The Khairpur Meers' purpose in agreeing to sign the treaty was to restore Meer Rustam the throne, along with his previous rights. While Outram was in Hyderabad, Napier was leading a military unit to the city to provide reinforcement to the commissioner there. The Meers, too, were making military preparations by marshalling their troops. Napier instructed Outram to persuade the Meers to disperse their troops. Outram wanted to help the Meers and advised them to sign the treaty because otherwise Napier could take military action against them. As a result, on 9 February 1843, the Meers of Khairpur agreed to sign the treaty. The Baluchi chiefs were angry at the injustice done to Meer Rustam and wanted Outram to restore to him his land; Outram could not do this. ${ }^{204}$ Meer Nasir Khan of Hyderabad also appealed to Outram to take from Meer Rustam only the land

Ibid., 267-269.

P.N. Khera, British Policy Towards Sindh up to its Annexation-1843, rev. ed. (Delhi: Ranjit Printers and Publishers,1963), 92. Ibid., 93. Mirza Kalich Beg, A History of Sind, V. II, $2^{\text {nd }}$ ed., (Karachi: Scinde Classics, 1982), 253 P.N. Khera, British Policy Towards Sindh up to its Annexation-1843, (Delhi: Ranjit Printers and Publishers, 1963, $1^{\text {ST }}$ Pub.1941), 94. Fredunbeg, A History of Sind, V. II, 253.
} 
between Subzal and Roree, leaving the rest of his territory in his possession. Nasir Khan told the Court of Directors in September 1843:'I entreated [Outram] vehemently on this subject; imploring him not to suffer Meer Rustam Khan, who was an old man of eighty-five years, to become a homeless wanderer, but to permit him to retain the remainder of his dominion.... ${ }^{205}$ Outram replied that it all depended on Napier's decision. Napier, on 1 January 1843, removed Meer Rustam from his throne and made Meer Murad Ali the principal chief of Upper Sindh. This led to agitation against the British in Hyderabad. Napier, who was thirty miles away from Hyderabad, sent soldiers to give protection to Outram against Baluchis, who had mounted an armed uprising against him. The British actions alarmed the Meers. ${ }^{206}$ When the treaty was finally signed on 12 February 1843 , Outram was given a military escort to protect him from the angry Baluchis. Meer Nasir Khan of Hyderabad, when signing the treaty, said to Outram:

It was stipulated in former treaties that the English would protect the country of the Ameers; instead of which, you are assigning it to another, and as regards Kurrachee, as you value one share of its revenue at Rs. 50,000, how does it happen that you estimate the other three shares belonging to Meer Mahomed Khan, Meer Shahdad Khan and myself, at Rs. 25,000 each; what justice is there in this? Helpless, I affixed my seal to the treaty... ${ }^{207}$

All the Meers except Meer Nasir Khan of Hyderabad signed the treaty. Napier continued his military advance towards Hyderabad even after the treaty signing. ${ }^{208}$ Meer Nasir Khan of Hyderabad, wanted to settle the dispute with the British in a friendly way, but he and Meer Mahomed were forced by the Baluchi subjects to mount an attack on the British. ${ }^{209}$

Meer Nuseer Khan of Hyderabad to the Court of Directors, 22 September 1843 in Beg, A History of Sind, V. II, $2^{\text {nd }}, 267$.

Khera, British Policy Towards Sindh up to its Annexation-1843, 95.

Meer Nuseer Khan of Hyderabad to the Court of Directors, 22 September 1843 in Mirza

Kalich FredunbegBeg, A History of Sind, V. II, $2^{\text {nd }}$ ed., (Karachi: Scinde Classics, 1982), 267.

Talpur, Talpur Rule in Sindh, 88

Fredunbeg, A History of Sind, V.2, 262-265. 
Meer Sobdar, however, was still supporting the British. Instead of making preparation for war, he was busy with preparations for the two weddings of Meer Hussain Ali and his son, Fateh Ali. The Baluchis however, on 15 February 1843, led by two Meers attacked the British Residency in Hyderabad and Outram and his men had to escape in a steamer. On 17 February a battle was fought between the Baluchis and the British at Miani in Sindh. The battle of Miani involved two thousand two hundred and fifty-six British soldiers and thirty thousand Baluchis. The British won the battle and suffered sixty-three fatalities. On the Baluchis' side, however, five thousand men were killed in the battle. ${ }^{210}$

After the battle of Miani all the Meers of Sindh except Sher Muhammad Khan of Meerpur surrendered to the British. On 12 March Sindh was declared to be a British possession. Meanwhile, final preparations were made for a final showdown between Napier and Meer Sher Muhammad. Military reinforcement was sent to Napier near Hyderabad. Sher Muhammad in the meantime had advanced to Dabo near Hyderabad. The 'battle of Dabo' that was fought there on 26 March 1843 saw the defeat of Sher Muhammad Khan. This completed the British conquest of Sindh. ${ }^{211}$ Sher Muhammad fled to the Thar where he was followed and Umarkot was taken on 4 April $1843 .^{212}$

After the battle of Miani Napier wrote to the Governor-General and told him that 'the superiority of the musket and bayonet over the sword, shield and matchlock' was displayed in the battle.

...Down went these [Baluchis] bold and skilful swordsmen under the superior power of the [British] musket and bayonet... Meer Rustam Khan, Meer Nasir Khan, and Meer Wallee Muhammad, of Khyrpore, Meer Nusir

History of Alienations in the Province of Sind, Compiled from the Jagir and Other Records in the Commissioner's Office, on the Authority of Bombay Government Resolution no. 12, Dated $2^{\text {nd }}$ January 1878, Revenue Department ( Karachi: Commissioner's Press, 1886), 17. 
Khan, Meer Shahdad Khan and Meer Hoosein Ali Khan, all of Hyderabad, came into my camp and surrendered their swords as prisoners of war. ${ }^{213}$

Historians such as P. N. Khera (1941) have also attributed the British victory in 1843 to the superiority of British weapons. Even so, while British weaponry used in the battle of Miani was superior to that of the Meers, the war against the Meers was won by the British long before the military battle began. The British victory was due to several factors. Particularly important was the British manipulation of the different Meers' self-interest. So too was the weakening of the Meers' institution through the imposition of a series of treaties before 1843.Political contestation between Meer Rustam and Meer Ali Murad was exploited by Napier to drive the former from Khairpur. Ali Murad's alliance with Napier, Meer Sobdar's loyalty to the British and the non-participation in the battle by Meer Muhammad and Meer Sobdar all contributed to the British victory on the battlefield.

Khera suggests that Napier's leadership of the British army in the battle was another reason for the military victory. ${ }^{214}$ British military leadership contrasts with the Meers' weak and even non-existent leadership of the Baluchis. The Meers did not encourage the Baluchis to get out of their camps frequently unlike Napier who constantly asked his soldiers to actively engage in the battle. ${ }^{215}$ Khera concludes his analysis of the annexation of Sindh with this assessment: 'Napier wanted the war and prepared the case; Ellenborough wanted Sindh and believed that case; and the conquest was the result. ${ }^{216}$ Outram also gave a lot of weight to Napier's role in the annexation of Sindh. Outram in his work Conquest of Scinde : a Commentary, published in 1846, said:

I was employed amicably to control, not to subvert, the Ameers and did so for three years. Sir Charles Napier had ostensibly the same duty to perform for his Government; in less than as many months he picked a quarrel with

Ibid., 257.

Khera, British Policy Towards Sindh, 103. Ibid., 103-104. Ibid., 110. 
them and commenced hostilities; drove them from their habitations, hunted them until compelled to resist; hurled them from their thrones; sacked their capital; and seized their country! ${ }^{217}$

After the annexation of Hyderabad, the Meers' property was plundered for seven days; according to Meer Nasir Khan, 'everything in fact of the value of a needle', was taken. He reported to the court of Directors on 22 September 1843 that the British sepoys sold the plundered gold, jewellery and valuables in Hyderabad. He added: 'Truly his [Napier's] slaughter of the people of Sinde and plundering their property was at the expense of the Queen of England. ${ }^{218}$ Historian P.N.Khera, suggests that Napier became remorseful and lamented the annexation when he said 'Peccavi' (Latin for 'I have sinned'). ${ }^{219}$ There is, however, a good deal of controversy over Napier's meaning; was he genuinely remorseful or was he punning ('I have Sindh')? Or is the story invented?

Historians have generally placed responsibility for the annexation of Sindh in the hands of Napier and Lord Ellenborough. Parveen Talpur (2002) judges Lord Ellenborough's policies to be the critical factor. The British Prime Minister Sir Robert Peel was critical of these policies; he had also argued that Peel had been critical of the appointment of Sir Charles Napier as commander of the British forces in Sindh. ${ }^{220}$ Robert Huttenback (2007) argues that the Afghan wars, which he considered to have a lot to do with annexation of Sindh, were supported by the home authorities. Lord Palmerston and John Hobhouse encouraged Auckland's policy on Afghanistan and recommended that he be appointed to a second term as GovernorGeneral. The ambitions of the 'men on the spot', that is Ellenborough and Napier, along with British commercial and security concerns were the reasons, according to

\footnotetext{
217 Extracts from Lieut.-Col. Outram's Commentary on "The Conquest of Sind" in Beg, $A$ History of Sind, 283. James Outram, Conquest of Scinde : a Commentary, (Cambridge: Cambridge University Press, 2012; first published in 1846), 26-27. Meer Nuseer Khan of Hyderabad to the Court of Directors, 22 September 1843 in Beg, A History of Sind, 262

$219 \quad$ Khera, British Policy Towards Sindh, 103.

220 Talpur, Talpur Rule in Sindh, 82.
} 
Huttenback, for the British annexation of Sindh. ${ }^{221}$ Michael H. Fisher (1993) argues that in comparison to regions such as Awadh, the 'subimperialists' or 'men on the spot' in Sindh were more independent from the Governor-General. ${ }^{222}$ Napier in Sindh acted independent of the Company and annexed Sindh for the sake of his own 'personal glory'. 223

H.T. Lambrick (1952) gives Lord Ellenborough the key role in the annexation of Sindh, he also suggests that the annexation resulted from the firm grip that the British kept of the Sindh region during the Afghan war and from Napier's pursuit of 'glory'. Napier was a non- Republican ultra-radical. He described the East India Company as a 'shopocracy'. In fact, he considered the Company to be tyrannical, and in his work published in 1840 he said: 'I prefer the despotic Napoleon to the despots of the East India Company. ${ }^{, 224}$ By the 1840 s, however, the Company no longer monopolised political and economic power in British India, and certainly did not enrich itself through conquest of Sindh in the way that Napier himself did. In Lambrick's view, the annexation can be explained by the ambitions of Charles Napier - his hunger for glory, fame and riches; he accrued a huge fortune after the annexation. ${ }^{225}$

Lord Ellenborough justified the annexation of Sindh on financial grounds. He expected that Sindh could yield a profit of $£ 500,000$ a year, and this amount would cover the losses incurred during the wars with China and Afghanistan. Revenue could be raised by the collection of transit fees on Malwa opium passing through Sindh. ${ }^{226}$ J.Y. Wong (1997) argues the importance of the economic factors underpinning the annexation of Sindh. He notes that Ellenborough was concerned about the cost of Britain's expansion in South Asia and the profitability of its empire.

\footnotetext{
$221 \quad$ Huttenback, British Relations with Sindh, 1799-1843, 113-120.

222 Ibid., 113-120, Michael H. Fisher, The Politics of the British Annexation in India, 1757-1857 (Delhi: Oxford University Press, 1993), 224.

$223 \quad$ Fisher, The Politics of the British Annexation in India, 224.

224 Major General Sir Charles Napier ed. Lights and Shadows of Military Life, Vol. 1, (London: Henry Colburn, 1840), 323-324.

225 Lambrick, Sir Charles Napier and Sind, 32-34.

226 J. Y. Wong, 'The British Annexation of Sindh in 1843: An Economic Perspective', Modern Asian Studies, V. 31, no. 2 1997, 234.
} 
British India's debts had nearly doubled between 1822 and 1828 (from $£ 29,388,000$ to $40,000,000$ ) as a result of the Burmese wars. Wong describes the annexation of Sindh an act of 'economic imperialism' by Ellenborough and 'subimperialism' by Napier. Lord Ellenborough encouraged Napier to annex Sindh. Lord Ellenborough, like his predecessors Lord Wellesley and Lord Bentinck, had avision that was broader than Napier's, who was motivated by dreams of personal fame.

Ellenborough had to be concerned about the British Empire's profits and losses, a reason why he was intent on holding a monopoly on the highly profitable Malwa opium trade to China. ${ }^{227}$

After annexation some radical changes were introduced by Napier in Sindh such as on 17 April he abolished all duties on imported goods. ${ }^{228}$ The Talpur rulers were pensioned off receiving about Rs 375,000 annually and could hold a jagir worth of Rs $150,000 .{ }^{229}$ Napier, to ensure the fielty from Baluch chiefs allowed them to continue with the possession of their jagirs and old ranks. Napier soon realised that the Talpur Meers had granted large amounts of land as jagir to Baluch chiefs, and to limit it, he declared on 2 November 1844 that not more than 5,000 bighas of land would be restored to the jagirdars. Jagirdars were to disband their troops. ${ }^{230}$ Sarah Ansari's work has shown that Napier patronised the pirs and waderos of Sindh who were landed elites by restoring their jagirs and collaborated with them in the countryside. ${ }^{231}$ On 1 October 1847 Napier left Karachi. Sindh, on the recommendation of Henry Hardinge, the Governor-General on 18 September 1846 became a part of the Bombay presidency under Commissioner Richard Keith Pringle. Sindh became a separate province in 1936.

\footnotetext{
$227 \quad$ Ibid., 244.

$228 \quad$ History of Alienation, 17.

229 A.W. Hughes, A Gazetteer of the Province of Sindh (London: Georg Bell and Sons, 1874), 49.

231 Sarah Ansari, Sufi Saints and State Power, the Pirs of Sind, 1843-1947 (Cambridhe: OUP, 1992), 40.
} 


\section{Conclusion}

This chapter has shown that the annexation of Sindh was a process impelled by the contingency of events and often determined by the vulnerability of the Meers. Initially British contact with Sindh was spasmodic; it was contingent on immediate and local factors. Under the stewardship of Governor-General Lord Wellesley, however, the British annexation of Sindh came to be advocated in high places. Wellesley used the fear of the French and Afghan imperialism to extend the British Empire into Central Asia. The perception of threat from foreign powers like Russia, France, Persia and Afghanistan on the north-western frontiers of the British Indian Empire made Sindh strategically important for the security of the empire.

In the early 1800 s the Company began pressing the Talpurs for privileges, but annexation was not considered important by the Governors-General who followed Wellesley, despite dominant British voices in favour of annexation as a means of securing India's border. Annexation was again advocated in Delhi and London when Lord Auckland, in order to secure British imperial interest in India, decided to put a puppet ruler on the Afghan throne, a decision that led to the Afghan war of 1838 1842. Battles with and victory over the Talpurs in Sindh followed the inglorious defeat of 1842 in Afghanistan, and provided the pretext for what was by now the inevitable annexation of Sindh. The 1843 annexation was certainly a means of recovering 'glory' that Britain had lost in Afghanistan the year before. But the Governor General at the time, Lord Ellenborough, had an imperial vision much broader than the acquisition of the state of Sindh.

Annexation had become inevitable by the 1830s because the Company, committed to being the paramount power in the subcontinent, saw the need for involvement in Sindhi politics as a means of protecting its Indian Empire from invasion from the north. It needed a power base in Sindh in order to wage the 1838 42 Anglo-Afghan war. The military contingencies created by the Anglo-Afghan war made the control over the Indus river, and over Sindh through which it passed, a logistical necessity. Gaining control was facilitated by the weakness of the Sindhi polity. The Talpur Meers were institutionally divided, and the Meers themselves solicited British involvement in the mediation of their family brawls and border 
disputes. The institutional weakness of Meer administration was exploited by the British through the imposition of a series of commercial and political treaties. The mercantile class of Sindh supported the British army during the Afghan wars and showed a willingness to support and back the British push into Sindh. Many of the Meers also looked to the British for protection against the Sikhs; the British offered this protection in return for 'quid pro quo' that eventually led to the destruction of their institutions once Sindh was annexed. While Napier and Ellenborough were instrumental in engineering the annexation, what happened in 1843 was in fact the culmination of a long drawn-out and complex historical process that, for decades, had been gradually corroding the power of indigenous power holders on the northwest frontiers of British India 


\section{Conclusion}

The preceding chapters have documented the history of Sindh in transition from Mughal rule to British annexation. The thesis begins by examining the process of state formation by the Sufi Kalhora tribe under Mughal tutelage. The tribe's spiritual masters led their followers to put down sedentary roots in the Sindh area in the early eighteenth century. Although the Kalhoras' rise was facilitated by the Mughal state's weakness, tribe leaders continued to seek legitimation from the Mughals until the region west of the Indus River was absorbed into the Persian Empire in 1739. From this time, the right to rule Sindh required the sanction of the Persian king and, from 1747, of the Afghan king, because Ahmad Shah Abdali absorbed Sindh into the Afghan empire that year. The Kalhora regime's support base was rural, and a decline in agrarian production contributed to the regime's troubles later in the century. On the other hand, a significant expansion of trade helped sustain the Sindh state and resulted in the emergence of a strong mercantile class. The role of this new class was critical in the subsequent history of Sindh.

In the later phase of Kalhoran rule, heavy tribute payments to the Afghan state damaged the Sindh economy, and internecine and intra-tribal wars weakened the state politically. These factors explain the Kalhora regime's collapse in 1782. The Kalhoras were overthrown by tribesmen who had once been their disciples (murids) - the members of the Baluch tribe of the Talpurs. The Baluchis had originally been recruited to the Kalhora court as mercenaries. The transition from Kalhoran to Talpur rule occurred at a time of social as well as political volatility in Sindh. The Talpurs, when they took over the region, devised a tribal corporate system of governance. They created three principalities - Hyderabad, Khairpur and Meerpur, each ruled by their kinship coteries. Within the Hyderabad state, as many as four Talpur Meers ruled conjointly, so that the state was more like a Baluch tribal confederacy. The Talpur Meers ruled Sindh until 1843.

The study also examines the beginnings of British interest in Sindh. Dutch and English merchants made exploratory voyages along the river Indus during the mid-1750s, but the Dutch were eventually squeezed out by the English. The British East India Company, with encouragement from the Kalhora chief Ghulam Shah, opened a factory in Sindh in 1758 , but political instability during the reign of 
Sarfaraz Khan Kalhora, and that ruler's policy of privileging Afghan traders, resulted in the factory's closure in 1775.

The British again became interested in Sindh in the early nineteenth century, this time for strategic as well as commercial reasons. Lord Wellesley used the alarm caused by Napoleon's imperial ambitions and Afghan ruler Shah Zaman's threat to the security of British India as justification for extending British Indian influence into central Asia. In 1799 he sent a mission to Sindh to keep a watch on the activities of Afghanistan and France in the regions north-west of Sindh. The thesis shows how Sindh, because of its geographic location, became a part of what Arthur Conolly in 1841 called Britain's 'great-game' strategy for countering the threat of French and then Russian imperialism.

In the context of British rivalry with Russia and France, two schools of thoughts emerged among British officials concerned about the security of British India. One championed the idea of using Persia to help restrain the French in South Asia; the other called for a British alliance with Afghanistan. ${ }^{232}$ Wellesley convinced the British government to choose Persia over Afghanistan as the Company's Middle Eastern ally; he argued that British interests would be better served by Afghanistan remaining weak. His proposal that a Company factory be based in Sindh to monitor developments in Afghanistan brought Sindh into Britain's 'great game'.

The Meers of Sindh favoured an alliance with the British only when they felt threatened by Afghanistan or the Punjab. Wellesley’s first mission to Sindh in 1799 was not welcomed by the Meers because the Afghan threat had receded for the time being; Shah Zaman, their Afghan overlord, was preoccupied with political rivals at home. But in 1803 the renewal of the Afghan threat finally made the Meers turn to the Company for support. When Muhammad Shah, the then ruler of Afghanistan, marched towards Sindh to demand unpaid tribute, the Meers proposed an alliance with the British. The proposal was rejected because British priorities had changed. But they were to change again. By 1808 Lord Minto was becoming alarmed about possible threats to British India on its north-west frontier. 
Sindh had again become strategically important to the British, and they now decided to press the Meers for political and economic concessions by playing on their sense of insecurity. Ranjit Singh, ruler of the Punjab, was moving into territory close to Sindh and was emerging as a formidable power in the north-west. The authorities in Calcutta began to favour an alliance with Afghanistan, rather than Persia. But Sindh's rulers were not in favour of an Anglo-Afghan alliance and, in all probability, such an alliance would be opposed by Ranjit Singh who viewed the current ruler of Afghanistan, Shah Shuja, as a rival. Minto came to realise that conflicting interests among Britain's potential allies in central Asia made an alliance with any one of them inadvisable, and so he decided to send separate missions to Persia, Afghanistan, the Punjab and Sindh in 1808. That Sindh was included is noteworthy; it had obviously become important as a potential link between British India and the Middle East.

Captain Seaton was appointed leader of the Sindh mission that reached Hyderabad in mid-July 1808 . He submitted a number of proposals to the Meers, but failed to secure a treaty with them; his mission was considered a failure in Calcutta. ${ }^{233}$ The mission failed for a number of reasons, but particularly because the Meers hoped to win British military help in achieving independence from Afghanistan as well as absorbing two of its neighbours, Cutch and Umerkot, and the British were not willing to give this help. Seaton was recalled and Lord Minto tried again in 1809 , this time sending a party headed by Nicholas Hanky Smith to Hyderabad. Smith had more success than Seaton, and signed a treaty that provided for the permanent exchange of agents. But Smith could not get the Meers to agree to the reestablishment of a Company factory in Sindh, and the sticking point in negotiations was Cutch. Sindh's rulers continued to press for British support for its designs on Cutch, and again the British resisted that demand; they had interests in Cutch themselves. ${ }^{234}$

\footnotetext{
233 The proposals presented by Seaton and the difficulties his mission encountered are discussed in Chapter 4,

234 The aims, success and failures of the Smith mission to Sindh are examined in Chapter 4.
} 
With Napoleon's defeat in 1815, the possible French threat to India was mitigated. But now Cutch became a reason for renewing British contacts with Sindh. Sindh's borders had recently expanded to include Umerkot and the regions of Thar and Parkar, bringing it closer to Cutch (now a British protectorate). The plundering and looting raids into Cutch by Parkar tribesmen, the Khosas and Lunas, were of growing concern to the British. Finally, in 1819, a cross-border raid by Khosas tribesmen provoked decisive action. British troops were sent into Sindh to deal with the raiders, and at one point all-out war between Sindh and British forces looked possible. But neither side really wanted a war at this time: the Meers knew that their army was no match for the British, and the British recognised that they had not yet done the reconnaissance work needed to make an invasion of Sindh feasible. ${ }^{235}$ Having avoided a military confrontation, both sides now resumed their quests for a closer relationship premised on 'friendship'. The Meers asked for an alliance based on the terms of the 1809 treaty. The British were primarily concerned with the crossborder raids that were damaging the Company's cotton trade in Cutch; the mission sent to Sindh in 1820 aimed to solve this problem, and measures to deal with it were written into the new treaty signed with the Meers in February $1821 .^{236}$

We can see, therefore, that in the first two decades of the nineteenth century, the relationship between Sindh and the British moved forward in phases. It was shaped by both local and international factors. British concerns were typically broader than those of Sindh's rulers. But Sindh's troubled relationship with Afghanistan drew it into the wider conflict in which Britain was engaged. And the Company's ambition to be the paramount power in India inevitably led to its embroilment in local politics and conflicts; the Sindh-Cutch conflict is a case in point.

The British were always conscious of Sindh's commercial potential, but the political situation often impeded the development of a trading base there. The 1821 treaty, however, was a step forward for the British because it gave them special Chapter 5.

236 See Chapter 5.
} 
rights in Sindh (it specified that Europeans and Americans were not permitted to reside in Sindh; the only exception was Englishmen). Another sign of an improving relationship was Meer Karim's request to Bombay in 1827; he asked that a British doctor be sent to treat his ailing brother, Meer Murad Ali. Dr James Burnes's fourmonth stay in Hyderabad became an important milestone in the progress made by the British in Sindh after the 1819 crisis. Burnes' detailed account of what he saw included observations of the rivalries and conflict among the various Meers. ${ }^{237}$ This information about Sindh's fractured politico-social structure proved very useful to the British, particularly when the Meers invited English agents in Sindh to mediate their intra-tribal rivalries. These mediations later strengthened the Company's hand when negotiating commercial privileges for the British in Sindh, particularly the right to survey the Indus river in the early 1830 s and the subsequent opening of the river to British trade.

As they had earlier, international developments in the 1830s significantly influenced British policy in relation to Sindh. Russia's new alliance with Persia, formalised in the 1828 treaty of Turkmanchy, brought Russia dangerously close to British India's north-western border. This caused the British authorities now to favour an alliance with Afghanistan as the means to protect British imperial interests in India. Accordingly, Lord Bentinck, Governor-General of India from 1828 to 1835, withdrew the British mission from Persia and adopted an active forward policy in regions west of the Indus. This forward policy increased Sindh's importance; in Bentinck's view, it had become necessary to establish a stronger British presence there. In 1831 he sent Alexander Burnes on an exploratory mission to Sindh, the main task of which was to survey the river Indus.

The next four or five years saw an intensification of the British push into Sindh. The Meers at first quite strenuously resisted British pressure on them to open the Indus to British trade. Nor did they want to let British surveyors do the necessary survey work first. The Meers eventually caved in because of the growing threat posed by Ranjit Singh in the Punjab and the promises given by the British to keep 
Ranjit out of Sindh. Henry Pottinger's mission to Sindh in 1831 - 32 was particularly important. Pottinger signed treaties with the Hyderabad and Khairpur Meers that more or less opened the floodgates. British traders were now free to use the Indus as a transport route for all merchandise except military equipment (armed vessels were also not allowed). Toll charges on goods shipped along the river were fixed, and the treaties provided for the strict supervision of toll collections. And eventually the Meers also acquiesced to the Company's demand that it be allowed to appoint a British resident to the Sindh court.

Strategies used by the British to gain a foothold and then expand in Sindh were similar to strategies they had used in other Mughal successor states such as Carnatic and Hyderabad (in south India). They exploited and exacerbated the political divisions they found in the regions that they eventually conquered. The Company justified the annexation of Sindh in 1843 on the grounds that the Talpur rulers were not fit to rule, that the Sindh tribes were barbaric, and that the Hindus in Sindh were oppressed. This thesis has critically examined the alleged failings of the Sindhi Meers and their regime. It argues that flaws in the political structure presided over by the Talpurs were not new, but it was international factors that pulled Sindh into the orbit of British empire building. Furthermore, the Sindh state when ruled by the Talpur Meers was less oppressive than had been the earlier Kalhora regime. As the Afghan state became more powerful, its demand for tribute from Sindh became more regular, with the result that the Kalhora rulers taxed their subjects more heavily. Onerous taxes fuelled rebellion among Sindh's tribal population. There is little evidence of tribal unrest in Sindh under Talpur rule; this can be explained by a reduction of land taxes which, in turn, can be explained by political turmoil in Kabul and the end of Sindh's tribute payments to the Afghan king. The Talpurs were quick to provide tax relief to cultivators because most were members of their own tribe, the Baluchis.

By the early nineteenth century, however, the Sindh state was weak, and this is because it was divided. Some of the divisions can be traced back to the early 1780s, when the new Talpur regime divided Sindh into three principalities. Other conflicts were new, particularly the conflict over the succession to the Sindh throne in the early 1830s. The British carefully noted the conflicts, and worked at further 
dividing the Meers by playing on their fears of expansionist neighbours, namely the Pubjab and Afghanistan. Under sustained pressure from the British, the Meers in 1836 finally agreed to allow a British Resident in Hyderabad, and the permission was written into a treaty in 1838. The stationing of British political agents in the seats of regional power was a strategy that the British had used in other Mughal successor states prior to their annexation. But in Sindh the Company had to use the threat of direct military action against Sindh if its request to install an agent in Hyderabad was not met. It would seem that the Meers were well aware of the political implications of having a British agent at the Hyderabad court.

By the late 1830s, the British had decided to install a compliant ruler on the Kabul throne and that required a military incursion into Afghanistan. The importance of Sindh now became critical. The Meers were asked not only to give free passage through Sindh to the 'Army of the Indus', but also to provision the army while it was in Sindh territory. Some of the Meers, including the principal Meer of Hyderabad, Meer Noor Muhammad Talpur, were reluctant to meet the Company's demand. This is the point at which Sindh's mercantile class emerged as a major player in the expansion of British power in Sindh. Merchants supplied the 'Army of the Indus' and ensured its safe passage to Afghanistan. As did the mercantile class in Bengal, Gujarat and other Indian states, the merchants of Sindh preferred the British to their local rulers.

During both the Kalhora and the Talpur periods, the traders of Sindh, who were mainly from the Hindu Bania caste, felt burdened by the high transit duties on commercial goods. At the beginning of Talpur rule, Sindh's merchants were opposed to the British push into Sindh; later, however, when the British emerged as a major political power in India, they gave them their support. A leading merchant, a Hindu named Seth Naomal Hotchand Bhojwani, played a particularly important role. He helped the British not only because he saw the commercial benefits to be gained from cooperating with them, but also because he had a personal grievance against the Talpurs; his father had lost out in a dispute with Muslims in Karachi. ${ }^{238}$ Just one 
example cannot count as evidence that the Hindus were generally oppressed under the Talpurs. But it was certainly the Hindu traders who resented the heavy transit duties and pressed for their removal. And it is likely that they anticipated gaining commercial advantages if they supported the British. It should be noted that the Banias of Sindh had acted as agents for the Dutch in the mid-eighteenth century. Broadly speaking, then, it seems probable that the 'profit motive' drew at least one sector of the Sindh population into serving the imperial designs of the European powers in Sindh.

British pressure on Sindh became intense in 1838. Governor-General Lord Auckland made a number of heavy, unfair demands of Sindh's Meers. As well as paying for the protection and provisioning of the 'Army of the Indus', the Hyderabad and Khairpur Meers were asked to maintain, at their own expense, a British subsidiary force. The Meers of Khairpur were to give the British the right to use the fort of Bukka; in return the British would make Khairpur a British dependency so that it could be more independent of Hyderabad. To facilitate the free flow of trade, transit duties on goods transported on the river Indus were to be removed. And Sindh's Meers were told not to maintain political relations with any outside power without the consent of the British. ${ }^{239}$ Meer Rustam of Khairpur accepted all the British demands. When the British threatened to annex the city of Karachi, the Hyderabad Meers also buckled under.

The British manoeuvrings in Sindh in 1838 offer clear evidence of Auckland's 'divide and conquer' strategy. The different Meers were treated differently according to their disposition and behaviour towards the British. The same strategy was employed in other Mughal successor states of India. Auckland was responsible for initiating the first Anglo-Afghan war of $1838-1842$. He manipulated Sindh politics and he exploited Sindh's resources in his prosecution of the war. However the British Afghan expedition soon turned into a disaster. After placing Shah Shuja on the Kabul throne, the British could not provide the support needed to make his position secure. Company resources were now redeployed to 
further the British imperial designs elsewhere, including the opening of China to foreign trade by means of he so-called 'opium wars'.

The political feuds among the Meers and their declining authority facilitated British intervention in Sindh. The Meers expected that the British would remove their garrison from Sindh once the Afghan war was over, but this did not happen. Meer Nasir Khan of Hyderabad wanted to be the principal Meer of Hyderabad and it was reported that he had written to Diwan Sawan Mal of Lahore to seek his help against the British. Meer Rustam too was suspected of having allied with Sher Singh, the ruler of Lahore. This was a situation too volatile for the British to allow on the north-western frontier of their Indian territories.

Lord Ellenborough succeeded Lord Auckland in early 1842, just when the British were facing disaster in the first Anglo-Afghan war. There was significant opposition to Shah Shuja among Afghanis, many of whom were in favour of Dost Muhammad's reinstatement as ruler. Ellenborough, therefore, quickly became preoccupied with the Afghan affair and with repairing the damage done to the reputation of the British, and so he could not immediately deal with the issue of Sindh. The task of investigating the loyalty of the Meers was handed to Captain James Outram, the Company's political agent in lower Sindh. Outram became a supporter of the Meers and acted as a mediator between the British and the Meers on several occasions. He also settled boundary disputes among the quarrelling Meers of Hyderabad and Khairpur. Ellenborough, intent on regaining the lost 'glory' of the British Empire by waging a few successful wars in India, and realising the pro-Meer attitude of Outram, handed over the work of investigating the charges against the Meers to Charles Napier; Napier was appointed commander of the British troops in Sindh in 1842.

Both Napier and Ellenborough have been blamed for the annexation of Sindh in 1843 by historians such as H.T. Lambrick, H.A. Huttenback and P.N. Kherra. Napier, it is argued, wanted to annex Sindh as a means of enhancing the image of the British after the unsuccessful Afghan expedition and for the achievement of 'personal glory'. The findings of this study are different; it argues that the annexation of Sindh in 1843 was the culmination of a long drawn-out process, starting in the early nineteenth century, of a foreign power's manipulation and coercion of Sindh's 
rulers. The first Anglo-Afghan war initiated by Auckland accelerated this process; it certainly did not begin it. To win Sindh's submission, Napier levelled a number of charges against Meer Rustam; he accused the Meer of breaching the provisions of treaties he had signed, of levying tolls on Indus traffic, of allying with the Punjab against the British. There is no evidence in British annexation records to support any of these charges. Napier levelled the charges in order to justify the annexation of Sindh; Outram protested because he believed annexation to be unjust.

In the final battles of Miani and Dubo between the Meers and the British in 1843, the Sindhi Baluchi tribes offered active resistance to the British, while the mercantile class, composed mainly of the Hindu Bania caste, allied with the British. After annexation Sindh was incorporated into the Bombay Presidency and the British relied on the local powerful groups to extend their rule over the various tribes of Sindh. The Sufi pirs were patronised, their landed possessions secured, because they could act as intermediaries between the British and the tribes of Sindh.

The findings of my study of Sindh's century-long transition from Mughal to British rule give partial endorsement to the explanation offered by scholars for British annexation of other Mughal successor states.Revisionist analyses of Mughal India take issue with the argument that economic decline in the sub-continent made colonisation by the British possible. My study also challenges the 'economic decline' theory by showing that the early Kalhora and Talpur states were more successful economically than the Mughal rule in Sindh had been before 1737. The late Mughal period was certainly disrupted by tribal unrest and saw a drop in revenue collection, and it is true that tribute collections by the Persian and then Afghan state were economically draining, The Kalhora rulers, however, took measures to develop the economy. One initiative was the invitation to the East India Company to open a factory in Sindh. Also, the construction of irrigation canals enabled as increase in agrarian production beyond levels achieved during the Mughal era. And there was growth of commercial centres such as Karachi and Hyderabad. This and trading links to Muscat and ports on the Persian Gulf, contributed to the increasing prosperity of the mercantile class. Moneylenders also grew in wealth and status.

Damage was done by the intra tribal feuding in the later Kalhora periods and then among and Talpur, but there were fewer tribal protests against the Talpurs, and 
the Baluchis supported the Talpurs in the final struggle against the British. Power conflicts caused a gradual decline of Sindhi polity under the later Talpurs. Nonetheless, in the eighteenth century, although the Talpur rule was kin based, it was more effective than the Mughal rule in Sindh had been.

My thesis thus contests the old school of historiography relating to eighteenth century India by showing that, in Sindh the pre-colonial period was not a period of decline. And although it agrees with the revisionist scholars who find economic growth in the 1700s, it is critical of their primary focus on the economy and their inadequate consideration of political factors. My study shows that political rivalries among the Talpur Meers, as well as their problematic relationship with the local mercantile classes, were the causes of their regime's decline and provided a motive for the British to annex Sindh. My history of Sindh in transition, therefore, takes issue with and revises both the early and the revisionist scholarship of eighteenth century India.

My argument, broadly, is two-pronged. First, I aim to show that one of the major features of Sindhi politics was continuous tribal competition and conflict for land and resources; and secondly, that such a situation in a region that was strategically important to them was unacceptable to the British in India. Sindh remained a peripheral region during the Mughal period; the Mughals lost Sindh to Persia, but Persia did not ever try to control the state directly and as a consequence, Sindh enjoyed significant political autonomy in the eighteenth century. It continued to be peripheral to British imperial interests until the international situation changed, and Russian and French threats became real in British perception. It was at this stage that the British realised the geo-political as well strategic importance of Sindh, and efforts were made to curtail the political autonomy of its rulers. The Company's ambition of becoming a paramount Indian power led to its involvement in Sindhi politics. To protect its Indian empire from invasion from the north it decided to use Sindh as a military base from which to prosecute the first Anglo-Afghan war; as we know, this had disastrous consequences. And this led to further pressure on Sindh, becauseto recover the dignity and 'glory' that was lost after the defeat in the Afghan war, Charles Napier finally decided to go ahead with the plan of annexing Sindh, a strategy that required engaging in battles against the Talpurs. 
The thesis also takes issue with imperial historiography, which tries to claim that annexation happened more or less overnight and was the work of overzealous 'sub-imperialists', such as Sir Charles Napier or Lord Ellenborough; these men are said to have taken on the spot ad hoc decisions designed to further their imperial ambitions. This explanation takes no account of a long-drawn-out process of 'transition' in Sindh, a process that involved a number of factors. Long before the actual annexation took place, as early as the mid seventeenth century, the importance of Sindh for commerce was realised by the British; their first exploratory mission to Kalhoran Sindh was sent from Bombay in 1757. Then, after the fall of the Kalhoras in 1783, the British began pressing the Talpur Meers for trade privileges. Navigation of the Indus became a major issue, but annexation was not seriously considered until the 1800 s, and only very seriously in the 1830 s.

In the end, the annexation of 1843 was facilitated by several local political factors: the inter-tribal rivalry within the Talpur ruling family; the Meers' insecurity in relation to powerful neighbours that caused them to seek British protection; and the local mercantile class's support for the British. The existing imperial historiography explains the British annexation only in terms of French and Russian threats and the local ambitions of Napier, Ellenborough-that is, 'the men on the spot'. This thesis, on the other hand, has shown that while international factors had made Sindh strategically important to the British, the annexation was the end result of a long- draw-out process involving a complex set of factors that gradually corroded the local political structure of Sindh. In one respect, however my study confirms the existing historiography. It shows how the East India Company gradually undermined the authority of the Meers through a series of unfair treaties over almost four decades, just, as it had done in the past in Lucknow, Hyderabad or Carnatic. Annexation was only the inevitable culmination of this and other long-term processes. 


\section{Appendix}

\begin{tabular}{|c|c|}
\hline \multicolumn{2}{|r|}{$\begin{array}{l}\text { Miscellaneous Taxes and Levies } \\
\text { Collected during the Kalhora and Talpur Periods }\end{array}$} \\
\hline $\begin{array}{l}\text { peshkush or } \\
\text { jaziyo }\end{array}$ & a tax on Hindus \\
\hline \multirow{2}{*}{$\begin{array}{l}\text { sarshumari } \\
\text { isnafigran }\end{array}$} & taxes on woodsmiths, ironsmiths, textile dyers and other labourers \\
\hline & a monthly tax on goods sold by caravan trade brokers \\
\hline charki & tax on land and garden irrigated by water-wheels \\
\hline havai & $\begin{array}{l}\text { goods carried by ships which sank or broke down went to the royal } \\
\text { treasury }\end{array}$ \\
\hline ijara Colaba & a tax on land watered by flooding \\
\hline haqqabo & an infrequently imposed tax paid by zamindars on water \\
\hline ijara Patan & $\begin{array}{l}\text { a tax on trade conducted on river banks, usually one or two percent of the } \\
\text { load's value, collected by people with contracts to collect the tax on } \\
\text { specified sections of river banks }\end{array}$ \\
\hline sardarakhti & $\begin{array}{l}\text { a tax collected from fishermen that was one-third or half of the value of the } \\
\text { total haul }\end{array}$ \\
\hline zardarakhti & $\begin{array}{l}\text { a tax on harvested fruit at the rate of one-third or half of the value of the } \\
\text { total amount of fruit harvested }\end{array}$ \\
\hline shikarmari & $\begin{array}{l}\text { a tax collected from fishermen at the rate of one-third or half of the value of } \\
\text { the total haul }\end{array}$ \\
\hline maveshi & a tax collected on the sale of beasts of burden \\
\hline tarazu & a tax collected on goods sold at market \\
\hline panchi & a tax collected on cattle raised on government land \\
\hline ghuto & a tax collected on profits raised by brewers of alcohol \\
\hline salamati kashti & $\begin{array}{l}\text { a tax of six anas imposed on every ship or boat which returned to shore } \\
\text { after trading }\end{array}$ \\
\hline raizki & $\begin{array}{l}\text { every buyer paid one ana on purchased goods worth one rupee and five } \\
\text { percent of the value of purchased goods worth more than one hundred } \\
\text { rupees; Sahukars and big businessmen paid just four percent }\end{array}$ \\
\hline \multirow[t]{2}{*}{ amini } & $\begin{array}{l}\text { remuneration given to the Amin who mediated disputes between } \\
\text { zamindars }\end{array}$ \\
\hline & $\begin{array}{l}\text { payments demanded by local Haqim from criminals who committed } \\
\text { murder or theft }\end{array}$ \\
\hline
\end{tabular}




\section{Bibliography}

\section{Primary Sources}

Archival Sources

Maharashtra State Archives, Mumbai

Sindh Factory Records, 1762-1764

Secret and Political Department, 1799-1800

Political Department, 1820-23

Political and Secret Department, 1831-1835

\section{National Archives of India, Delhi}

Foreign Department, Political Consultations, 1799-1843

Foreign Department, Secret and Separate Department Consultations, 1808-1810

Foreign Department, Secret Consultations, 1820-1843

Foreign Department, Secret General Letters to Court of Directors, 1808-1843

\section{Persian or Urdu}

Aazam, Seikh Muhammad.n.d. Jawahir-i Abbasia. MS. Karachi. Sindhi Adabi Board.

Arif, Jan Muhammad Munshi b. Muhammad. n.d. Jam-i-Badi. MS. Aligarh Muslim University.

Astarabadi, Muhammad Mehdi Khan. 1864. Tarikh-i-Jahan-Kushan-i-Nadiri. ed. Amahar Abadi. Tehran: Dunaiyi Kitab.

Kalhora, Noor Muhammad. n.d. Manshur-ul Wasiyat Wa Dasturul Hukumat. MS. Karachi: Rashidi Collection.

Khaif, Bagh Ali Mutklas. n.d. Name Naghaz. Karachi. M.S.. Sindhi Adabi Board. 
Khan, Khan Bahadur Khudadad. n.d. Lubb-i-Tarikh-i-Sindh. MS. Karachi. Rashidi Collection.

Khan, Nawab Shams-ud-Daula Shah Nawaz. 1888. Maathir-ul-Umra. Edited by Maulavi Abdul Rahim. Vol. 1. Calcutta: Royal Asiatic Society of Bengal.

Qamruddin. 2009. The Mahdawi Movement in India. rev. Delhi: Idarah-i Adabiyat-i Delli.

Rai, Lala Daulat. 1882. Mirat-i-Daulat-i-Abbasia. Karachi: Sindhi Adabi Board.

Rauf, Munshi Abdur. n.d. Guldadtan-i-Norais Bahar. MS. Karachi. Rashidi Collection.

Thattvi, Meer Ali Sher Qani. 1909. Tuhfat-ul-Kiram. Urdu ed. Karachi: Sindhi Adabi Board.

n.d. Tuhfat-ul-Kiram.MS. Karachi. Rashidi Collection.

\section{Printed Sources}

Aitchison, C.U. 1865. A Colleection of Treaties, Engagements and Sunnuds Relating to India and Neighbouring Countries. Containing the Treaties Relating to Sindh, Baloochistan, Persia, and Heart; Turkish Arabia and the Persian Gulf; and the Arabian and African Coast. Vol. VII. Calcutta: O.T. Cutter.

.1876. A Collection of Treaties, Engagements, and Sunnuds Relating to India and Neighbouring Countries. Vol. 2. Calcutta: Re-printed at the Foreign Office Press.

Burnes, Sir Alexander. 1834. Travels into Bokhara; Being the Account of a Journey from India to Cabool, Tartary and Persia; Also, Narrative of a Voyage on the Indus, from the Sea to Lahore, with Presents from the King of Great Britain; Performed under the Orders of the Supreme Government of India, in the Years 1831, 1832, and 1833 : Burnes, Alexander, Sir, 1805-1841 : Free Download \& Streaming. London: John Murray.

Burnes, James. 1974. A Visit to the Court of Sindh by James Burnes with an Introduction by Hamida Khurro. Karachi: Oxford University Press.

- 2004. Sketch of the History of Cutch. New Delhi: Asian Educational Services. (first printed in 1831).

Burton, Sir Richard F. 1851. Sindh and the Races That Inhabit the Valley of the Indus: With Notices of the Topography and History of the Province. London: W.H. Allen \& Co. 
Colchester, Lord. 1874. History of the Indian Administration under Lord Ellenborough in His Correspondence with Duke of Wellington. To Which Is Prefixed, by Permission of His Majesty, Lord Ellenborough's Letter to the Queen during That Period. London: Richard Bently.

Correspondence Relative to Sinde, 1836-1843.1843. London: J.L. Cox \& Sons.

Crow, Nathan, and Mubarak Ali Khan. 1987. Imperialism at Work: Crow's Report and Despatches on Sind. Lahore: Book Traders.

Cunningham, Joseph Davey. 1849. A History of the Sikhs, from the Origin of the Nation to the Battles of the Sutlej. London: John Murray.

Eastwick, E.B. 1849. Dry Leaves from Young Egypt: Being a Glance at Sindh Before the Arrival of Sir Charles Napier. By an Ex-Political [i.e. E.B. Eastwick]. London: James Madden.

Eastwick, Edward Backhouse. 1973. A Glance at Sind before Napier: Or, Dry Leaves from Young Egypt.Karachi: Oxford University Press.

Eastwick, William Joseph. 1844. Speeches of Captain William Eastwick on the Case of the Ameers of Sinde at a Special Court Held at the India House on Friday 26th January 1844. London: James Ridsway.

Falzon, Mark Anthony. 2004.Cosmopolitan Connections: The Sindhi Diaspora, 1860-2000. Netherlands: Koninklijke Brill NV.

Fraser, James. 1742. The History of Nadir Shah: Formerly Called Thamas Kuli Khan, the Present Emperor of Persia. ... At the End Is Inserted, a Catalogue of about Two Hundred Manuscripts in the Persic and Other Oriental Languages, Collected in the East. By James Fraser. London: W. Strahan.

Hamilton, Walter. 1828. The East-India gazetteer: containing particular descriptions of the empires, kingdoms, principalities ... of Hindostan, and the adjacent countries, India beyond the Ganges, and the Eastern Archipelgo, together with sketches of the manners, customs, institutions, agriculture ... of their various inhabitants. London: Parbury, Allen \& Co.

History of Alienations in the Province of Sind, Compiled from the Jagir and Other Records in the Commissioner's Office, on the Authority of Bombay Government Resolution no. 12, Dated $2^{\text {nd }}$ January 1878, Revenue Department. 1886. Karachi: Commissioner's Press.

Hotchand, Naomul, and H. Evan M. James. 1982. A Forgotten Chapter of Indian History as Described in the Memoirs of Seth Naomul Hotchand of Karachi. Karachi: Oxford University Press.

Hughes, A.W.1874. A Gazetteer of the Province of Sindh, London: Georg Bell and Sons.

Lal, Munshi Mohana. 1846. Life of the Amir Dost Mohammed Khan of Kabul: With His Political Proceedings Towards the English, Russian and Persian Governments, Including the Victory and Disasters of the British Army in Afghanistan. By Mohan Lal, Esq. London: Longmans.

1846. Travels in the Panjab, Afghanistan, Turkistan, to Balk, Bokhara, and Herat: And a Visit to Great Britain and Germany. London: W.H. Allen \& Co. 
Law, Sir Algernon. 1926. India under Lord Ellenborough, March 1842-June1844. London: John Murray.

Masson, Charles.1844. Narrative of Various Journeys in Balochistan Afghanistan The Panjab And Kalat. London:Richard Bentley.

Napier, Lieut.-Gen.William. 2011. The Life and Opinions of General Sir Charles James Napier, G.C.B. Cambridge: Cambridge University Press.( first pub. in 1857)

Oliver, Edward Emmerson. 1890. Across the Border : Or Pathan and Biloch. London : Chapman and Hall. http://archive.org/details/acrossborderorpa00oliv.

Panhwar. M.H.Treaties, Agreements, Grants, Engagements and Sanads between the British and Sindh Governments: 1758-1842.

http://panhwar.com/Books_By_Sani/Treaties-between-British-and-SindhGovernments.pdf; accessed 27/06/2015.

Pottinger, Sir Henry. 1816. Travels in Beloochistan and Sinde; Accompanied by a Geographical and Historical Account of Those Countries. London: Longman.

Thomas, R. Hughes. 1979. Memoirs on Sind, Selection from the Record of the Bombay Government, New ser. no.17. Karachi: Karimsons.

Wellington, Arthur Wellesley of. 1836. The Despatches, Minutes, and Correspondance, of the Marquess Wellesley, K. G. During His Administration in India. London: Murry.

Wellington, Arthur Wellesley 1st duke of. 1837. The Dispatches of ... the Duke of Wellington, Compiled by Lieut. Colonel Gurwood. Suppl. to Vol. 1/3 Index. London: John Murray.

Mirak, Yusuf and Muhammad Saleem Akhtar.1990. Sindh Under the Mughals: An Introduction To, Translation of and Commentary on the Mazahar-i-Shahjahani of Yusuf Mirak. Islamabad: National Institute of Historical and Cultural Research.

\section{Secondary Sources}

\section{English}

Abbott, Freeland. 1962. "The Decline of the Mughal Empire and Shah Walliullah." The Muslim World 52 (2).

Abraham, Susan. 1999. "'Steal or I'll Call You a Thief' : Criminal Tribes of India."” Economic and Political Weekly. Vol. 34. no. 27.

Alam, Muzaffar. 1994. "Trade, State Policy and Regional Change: Aspects of Mughal-Uzbek Commercial Relations, C. 1550-1750." Journal of the Economic and Social History of the Orient 37 (3).

1997. The Crisis of Empire in Mughal North India: Awadh and the Punjab, 1707-48. Delhi: Oxford University Press. 
Permanent Black.

1998. "Aspects of Agrarian Uprisings in North India in the Early Eighteenth Century'." In Muzaffar Alam and Sanjay Subrahmanyam, eds. The Mughal State: 1526-1750. Delhi: Oxford University Press.

Alam, Muzaffar, and Sanjay Subrahmanyam, eds. 1998. The Mughal State, 15261750. Delhi: OUP.

Alavi, Seema. 2002. The Eighteenth Century in India. New Delhi: Oxford University Press.

Ali, M. Athar. 1992. "The Mughal Polity- A Critique of 'Revisionist' Approaches'.” Proceedings of the Indian History Congress, Delhi.

Ali, Mubarak. 1994. Sindh Analysed: McMurdos's \& Delhoste's Account of Sindh. Lahore: Takhleeqat.

-2005. A Social and Cultural History of Sind: Based on the Accounts of the European Travellers Who Visited Sind. Lahore: Fiction House.

- 2005. "Umarkot: A Historic City of Sind, Studies on Sind." Essays on the History of Sindh. Lahore: Fiction House.

Álī, Shahāmat. 1848. The History of Bahawalpur: With Notices of the Adjacent Countries of Sindh, Afghanistan, Multan, and the West of India.London: James Madden.

Amini, Iradj. 1999. Napoleon and Persia: Franco-Persian Relations Under the First Empire. 1 edition. Washington, D.C.: Mage Publishers.

Ansari, Sarah F. D. 1992. Sufi Saints and State Power: The Pirs of Sindh, 18431947. Cambridge: Cambridge University Press.

Aquil, Raziuddin. 2010. Sufism and State Society in Medieval India. Delhi: Oxford University Press.

Arasratnam, S. 1998. "India and the Indian Ocean in the Seventeenth Century." In India and the Indian Ocean 1500-1800, edited by M.N. Pearson and Ashin Das Gupta. New Delhi: Oxford University Press.

Arnold, David. 1985. "Crime and Crime Control in Madras, 1858-1947.” In A. Yang ed. Crime and Criminality in British India. Tucson: University of Arizona Press.

Bakshi, S.R., and Rashmi Pathak. 2001. Punjab through the Ages. Delhi: Sarup \& Sons.

Baloch, Justice Meer Khuda Bakhsh Bijarani Marri. 1977. Searchlights on Baloches and Balochistan. Quetta: Gosha-e Adab.

Bandyopadhyay, Sekhar. 2008. From Plassey to Partition: A History of Modern India. New Delhi: Orient Blackswan Private Ltd.

Barendse, R. J. 2002. The Arabian Seas: The Indian Ocean World of the Seventeenth Century. New York: M.E. Sharpe.

Bayly, C. A. 1983. Rulers, Townsmen and Bazaars: North Indian Society in the Age of British Expansion, 1770-1870. Cambridge: Cambridge University Press. 
1990. Indian Society and the Making of the British Empire. Cambridge:

Cambridge University Press.

Bayly, Christopher Alan. 1989. Imperial Meridian: The British Empire and the World, 1780-1830. London: Longman.

. 1994. "The British Military-Fiscal State and Indigenous Resistance. India

1750-1820'.’ In L. Stone. ed. An Imperial State at War. Britain from 1689 to 1815, London: Routledge.

Bayly, Susan. 1995. "Caste and Race in the Colonial Ethnography of India." In The Concept of Race in South Asia, edited by Peter Robb. Delhi: Oxford University Press.

Bowen, H. V. 2008. The Business of Empire: The East India Company and Imperial Britain, 1756-1833. Cambridge: Cambridge University Press.

Brittlebank, Kate. 1997. Tipu Sultan's Search for Legitimacy: Islam and Kingship in a Hindu Domain. Delhi: Oxford University Press.

Bray, Denys. 1925. “Jats of Baulchistan.” In Indian Antiquary, 30-33. 54.

Cain, P.J. and A.G. Hopkins. 2003. "Prospective: Aristocracy, Finance and Empire, 1688-1850'." The Eighteenth Century in Indian History: Evolution or Revolution?. Delhi: Oxford University Press.

Cain, P. J., and Antony G Hopkins. 2013. British Imperialism: 1688-2000. New York: Routledge.

Calkins, Philip C. 1970. "The Formation of a Regionally Oriented Ruling Group in Bengal'," Journal of Asian Studies, XXIX (August).

Chablani, S.P. 1951. Economic Conditions in Sindh, 1592-1843. Calcutta: Orient Longmans Ltd.

Chandra, Satish. 1969. Parties and Politics at the Mughal Court, 1707-1740.

Aligarh: Dept. of History, Aligarh Muslim University. 1972. Parties and Politics at the Mughal Court, 1707-1740. 2d ed. New Delhi: People's Pub. House.

Chattopadhyaya, Brajadulal. 2005. The Making of Early Medieval India. 4th ed. New Delhi: Oxford University Press.

Chaudhuri, B. B. 2008. Peasant History of Late Pre-Colonial and Colonial India. New Delhi: Pearson Education India.

Chaudhuri, K.N. 1978. The Trading World of Asia and the English East India Company. Cambridge: Cambridge University Press.

Chaudhuri, Sushil.1975. Trade and Commercial Organization in Bengal, 1650-1720. Calcutta: Firma K. L. Mukhopadhyay.

Manohar. 1995, From Prosperity to Decline: Eighteenth Century Bengal. Delhi:

Cheesman, David. 1982.“'The Omnipresent Bania:' Rural Moneylenders in Nineteenth-Century Sind."Modern Asian Studies. Vol. 16. 3. 
Chhabra, G. S. 2005. Advance Study in the History of Modern India (Volume-2: 1803-1920). New Delhi: Lotus Press.

Chopra, Gulshan Lall. 1928, The Punjab as a Sovereign State, 1799-1839. Lahore: Uttar Chand Kapur \& Sons.

Cousens, Henry. 1975. The Antiquities of Sind. Varanasi: Bhartiya Publishing House.

Dahiya, Bhim Singh. 1980. Jats, the Ancient Rulers: A Clan Study. Sterling.

Dale, Stephen Fredrick. 1994. Indian Merchants and the Eurasian Trade, 16001750, Cambridge: Cambridge University Press.

Dalrymple, William. 2012. The Return of a King: The Battle for Afghanistan.

London: Blooms.

Daniel, Elton L. 2012. The History of Iran. California: The Greenwood Histories of Modern Nation.

DasGupta, Ashin. 1967. Malabar in Asian Trade, 1740-1800. New York: Cambridge University Press.

Digby, Simon. 1994. "Tabrrukat and Succession Among the Great Chisti Shykhs of the Delhi Sultanate." In Delhi Through the Ages, edited by R.E. Frykenberg. New York: Oxford University Press.

Dirks, Nicholas. 1989. "The Invention of Caste: Civil Society in Colonial India'." Social Analysis. Vol. 25, 42-52

Dupree, Louis. 1976. "The First Anglo-Afghan War and the British Retreat of 1842: the Functions of History and Folklore', East and West, Vol. 26, No. 3/ 4, 503-29

Durrani, Ashiq Muhammad Khan. 2009. "Afghans Conquest of Sindh During 18th Century.” In Journal of the Pakistan Historical Society. Vol. LVII. 2.

Eaton, Richard M. 1993. The Rise of Islam in Bengal Frontier 1204-1760. Berkeley: University of California Press. Ltd.

Elst, Koenraad. 2001. Decolonizing the Hindu Mind: Ideological Development of Hindu Revivalism. Rupa \& Co.

Ernst, Carl W., and Bruce Lawrence. 2002. Sufi Martyrs of Love: The Chisti Order in South Asia and Beyond. London: Palgrave Macmillan.

Evers, H. 1994. The Moral Economy of Trade: Ethnicity and Developing Markets. Routledge.

Fisher, Michael H. 1981. "British Expansion in North India: The Role of the Resident in Awadh." Indian Economic and Social History Review. Vol. XVII, 1. 6982.

1993. The Politics of British Annexation in India: 1757-1857. Delhi: Oxford University Press.

- 1993. "The Nawabs of Carnatic and the English East India Company." In The Politics of the British Annexation of India 1757-1857, edited by Michael H. Fisher. Delhi: Oxford University Press. 
Fisher, William Bayne, P. Avery, G. R. G. Hambly, and C. Melville. 1991. The Cambridge History of Iran. Cambridge: Cambridge University Press.

Fredenbeg, Mirza Kalichbeg. 1982. A History of Sindh. 2nd ed. Karachi: Scinde Classics.

Fried, Morton. 1975. The Notion of Tribe. California: Cummings Publishing Company.

Gallagher, John, and Ronald Robinson. 1953. "The Imperialism of Free Trade." The Economic History Review. Vol. VI. Second Series 1. 1-15.

Geertz, Clifford. 1968. Peddlers and Princes: Social Development and Economic Change in Two Indonesian Towns.Chicago: University of Chicago Press.

Gilmartin, David. 2004. "Irrigation and the Baloch Frontier." In Sufis, Sultans and Feudal Order, edited by Mansura Haider. New Delhi: Manohar.

Grewal, Jasjit Singh. 1998. The New Cambridge History of India, The Sikhs of the Punjab: Eastern India 1740-1828. rev ed. Cambridge: Cambridge University Press.

Guha, Ramachandra. 1999. Savaging the Civilized: Verrier Elwin, His Tribals, and India. Chicago: University of Chicago Press.

Habib, Irfan. 1969. "Potentialities of Capitalistic Development in the Economy of Mughal India." The Journal of Economic History 29 (1): 32-78.

. 1999. The Agrarian System of Mughal India 1556-1707. 2nd ed. New Delhi: Oxford University Press.

. 2002. "The Eighteenth Centuruy in the Indian Economic History." In The Eighteenth Century in India, edited by Seema Alavi. New Delhi: Oxford University Press.

2003. "The Eighteenth Century in Indian Economic History'.” In The Eighteenth Century in Indian History: Evolution or Revolution?, edited by P.J Marshall. Delhi: Oxford University Press.

Hardy, P., M.N. Pearson and J.F. Richards, 1976. "Articles on the Decline of the Mughal Empire'.” In Journal of Asian Studies. Vol. XXXV. No. 3.

Hasan, Farhat. 2004. State and Locality in Mughal India: Power Relations in Western India c 1572-1730. New York: Cambridge University Press.

Hasnat, Syed Farooq. 1981. "An Historical Survey of the European Interests and Control in the Persian Gulf Region." Journal of Research Society of Pakistan, xviii:33-52. No.2.

Hoebel, Adamson E. 2006. The Law of Primitive Man: A Study in Comparative Legal Dynamics. Cambridge: Harvard University Press.

Hopkirk, Peter. 2001. The Great Game: On Secret Service in High Asia. Oxford: Oxford University Press.

Huttenback, Robert A. 1962. British Relations with Sind, 1799-1843: An Anatomy of Imperialism. Berkeley and Los Angeles: University of California Press.

Ingram, Edward, ed. 1970. Two Views of British India: Private Correspondence of Mr.Dundas and Lord Wellesley, 1798-1801. Bath: Adams \& Dart. 
1984. In Defence of British India: Great Britain in the Middle East, 1775-

1842. London: Frank Cass.

Islam, Arshad. 2001. Islam in Sindh. Malaysia: International Islamic University of Malaysia.

Islam, Riazul. 1970. Indo-Persian Relations: A Study of the Political and Diplomatic Relations Between the Mughal Empire and Iran. Tehran: Iranian Cultire Foundation.

Jones, Justin, and Ali Usman Qasmi. 2015. The Shi'a in Modern South Asia, Religion, History and Politics. Delhi: Cambridge University Press.

Kamdar, Muhammad Saleem. 1996. Development of Capitalism in Agriculture: An Essay on the Nature of Transformation (change) of the 19th Century Agrarian Structure of Sindh Province in Pakistan.Stuart, Fla: M.S. Kamdar.

Kapur, Nandini Sinha. 2002. State Formation in Rajasthan: Mewar during the Seventh-Fifteenth Centuries. New Delhi: Manohar Publishers \& Distributors.

Kaye, John William. 1867. Lives of Indian Officers, Illustrative of the History of the Civil and Military Services of India. Vol. II. London: A. Strahan and Co., Ludgate Hill.

Khera, P.N. 1963. British Policy Towards Sindh up to Its Annexation-1843. Delhi: Ranjit Printers and Publishers.

Kolff, Dirk H. A. 1995. From Hindustani Diaspora to Indian Expansion: The Context of the First Fase of the Transition.

- 2002. Naukar, Rajput, and Sepoy: The Ethnohistory of the Military Labour Market of Hindustan, 1450-1850. Cambridge: Cambridge University Press.

Kulke, Hermann. 1995. The State in India, 1000-1700. Oxford: Oxford University Press.

Lai, Walton Look. 1993. Indentured Labor, Caribbean Sugar: Chinese and Indian Migrants to the British West Indies, 1838-1918. Baltimore: Johns Hopkins University Press.

Lakho, Ghulam Muhammad. 2008. "Sindh- Iran Relations during the Talpur Period." Journal of Pakistan Historical Society. Vol. LVI. 1.

Lambrick, H. T. 1952. Sir Charles Napier and Sind. Oxford: Clarendon Press.

Lari, Suhail Zaheer. 1994. A History of Sindh. Karachi: Oxford University Press.

Lawrence, Bruce. 2002. "The Earlist Chistiya and Shaikh Nizam Ud Din Awilya (d.1325)." In The Delhi Omnibus, edited by Percival Spear ,Narayani Gupta and Robert Frykenberg. Delhi: Oxford University Press.

Leonard, Karen. 1979. "The 'Great Firm' Theory of the Decline of the Mughal Empire'," Comparative Studies in Society and History, Vol. 21 (April): 151-67.

Lewis, Herbert S. 1981. "Warfare and the Origin of the State: Another Formulation." In The Study of the State, edited by Henri J.M Claessen and Peter Skalnik. The Netherlands: Mouton Publishers.

Lockhart, Laurence. 1938. Nadir Shah: A Critical Study Based Mainly Upon Contemporary Sources. London: Luzac \& Co. 
LØkkegaard, Frede. 1979. Islamic Taxation in the Classic Period. Lahore: Sind Sagar Academy.

MacFarlane, Charles. 1848. Our Indian Empire: Its History and Present State, from the Earliest Settlement of the British in Hindostan, to the Close of the Year 1846.

London: G. Routledge and Company.

MacMunn, George Fletcher. 1989. The Lure of the Indus: Being the Final Acquisition by the East India Company. rev. ed. Karachi: Royal Book Company.

Madra, Amandeep Singh, and Parmjit Singh. 2004. "Sicques, Tigers, or Thieves": Eyewitness Accounts of the Sikhs. New York: Palgrave Macmillan.

Majumdar, D.N, and T.N Madan. 1956. An Introduction to Social Anthropology. Bombay and Calcutta: Asia Publishing House.

Malik, Ikram Ali. 1966. "Ranjit Singh's Relations with the Amirs of Sindh: 18021839." In Sind Through the Centuries, edited by Hamida Khuhro. Karachi: Oxford University Press.

Malleson, G. B. 1882. The Founders of the Indian Empire: Clive, Warren Hastings, and Wellesley. Lord Clive. London: W. H. Allen.

Mariwala, C.L. 1993. "Commercial Navigation of the Indus: 1820-1832 A.D." In Sindh Observed. Lahore: Gautam Publisher.

Marshall, P. J., 1985. “Early British Imperialism in India'.” In Past and Present. Vol. Feb 1985. no. 106.1.

. ed. 1998. "Indian Society and the Establishment of British Supremacy, 1765-1818." In The Oxford History of the British Empire: Volume II: The Eighteenth Century. Oxford: Oxford University Press.

- 1998. "The British in Asia: Trade to Dominion,1700-1765." In The Oxford History of the British Empire: The Eighteenth Century. Oxford: Oxford University Press.

Mayaram, Shail, and M. S. S. Pandian, Ajay Skaria. 1982. Subaltern Studies: Muslims, Dalits, and the Fabrications of History. New Delhi: Permanent Black.

McLeod, John. 1999. Sovereignty, Power, Control: Politics in the State of Western India, 1916-1947. Leiden: Brill.

McMurdo, James. 1841. "The History of the Kalhora Family of Sindh, Descended from Addas, the Uncle of Muhammad the Prophet, and Commonly Called Abbasides." The Journal of the Bombay Branch of the Royal Asiatic Society. Vol. V. 1.

Mehta, Mohan Sinha. 1930. "Lord Hastings and the Indian States : Being a Study of the Relations of the British Government in India with the Indian States, 1813-1823." Bombay: D.B. Taraporevala Sons.

Morrock, Richard. 1973. "The Heritage of Strife: The Effects of Colonialist "Divide and Rule" Strategy upon the Colonised People."' In Science and Society. Vol. 37. 2. Mukherjee, Rudrangshu. 1982. "Trade and Empire in Awadh:1765-1804.” Past and Present. 94. 
106.

1985. "Early British Imperialism in India: A Rejoinder." Past and Present.

Murray, Julie. 2007. "Company Rules: Burke, Hastings, and the Specter of the Modern Liberal State." American Society for Eighteenth-Century Studies(ASECS), Eighteenth- Century Studies, 41.1.

Nadri, Ghulam A. 2009. Eighteenth-Century Gujarat: The Dynamics of Its Political Economy, 1750-1800. Leiden and Boston:Brill.

Napier, Major General Sir Charles. 1840. Lights and Shadows of Military Life. Vol. 1. London: Henry Colburn.

Nightingale, Pamela. 1970. Trade and Empire in Western India: 1784-1806.

London: Cambridge University Press.

Owen, D.F. 1934. British Opium Policy in China and India. Connecticut: Yale University Press.

Page, David. 1982. Prelude to Partition: The Indian Muslims and Imperial System of Control, 1920-1932. New York: Oxford University Press..

Panhwar, M.H., 1979, Heroic Struggle of Sindh against Feudalism (1500 AD to1843 $A D)$, http://panhwar.com/Article02.htm; accessed 29 June 2015.

- 1993. "Introduction." In The Dutch East India Company (VOC) and Diewel-Sind (Pakistan), in the 17th and 18th Centuries: Based on Original Dutch Records, edited by Willem Floor. Institute of Central \& West Asian Studies, Karachi: University of Karachi.

Parthasarathi, Prasannan. 2001. The Transition to a Colonial Economy: Weavers, Merchants and Kings in South India, 1720-1800.Cambridge: Cambridge University Press.

Pati, Biswamoy and Waltraud Ernst. 2010. India's Princely States People, Princes and Colonialism. Delhi: Ratna Sagar (P) Ltd.

Pearson, M.N. 1972. "Political Participation in Mughal India'," Indian Economic and Social History Review, Vol. IX (June).

Pemble, John. January1976. "Resources and Techniques in the Second Maratha War." In The Historical Journal. Vol. 19. 2.

Perlin, Frank. 1978. "Of White Whale and Countrymen in the Eighteenth Century Maratha Deccan: Extended Class Relations, Rights, and the Problem of Rural Autonomy Under the Old Regime." Journal of Peasant Studies, 5:172-237. 2.

Porter, Bernard. 2004. The Lion's Share: A Short History of British Imperialism, 1850-2004. London: Pearson Longman.

Prakash, Om. 1985. The Dutch East India Company and the Economy of Bengal, 1630-1720. Princeton: Princeton Univ Press.

- 2004. Bullion for Goods: European and Indian Merchants in the Indian Ocean Trade, 1500-1800. Delhi: Manohar.

Qalb-i-Abid, S. 1983. "Ranjit Singh and the Fall of Multan." Journal of Research Society of Pakistan. Vol. XX. 3. 
Qamruddin. 2009. The Mahdawi Movement in India. rev. ed. Delhi: Idarah-i Adabiyat-i Delli.

Quetta, M. Anwar Roman. 1959. "Brahuis of Quetta-Kalat Region." Journal of the Pakistan Historical Society. Vol. VII. Part III.

Ratnagar, Shereen F, and Rudolf C Heredia. 2003. "Concluding Summary." In Mobile and Marginalized Peoples: Perspectives from the Past. Delhi: Manohar.

Ray, Rajat Kanta. 1998. "Indian Society and the Establishment of British Supremacy, 1765-1818." In The Oxford History of the British Empire: Volume II: The Eighteenth Century, edited by P. J. Marshall. Oxford: Oxford University Press.

Richards, J. F. 1981. "The Indian Empire and Peasant Production of Opium in the Nineteenth Century." Modern Asian Studies 15 (1): 59-82.

Richards, J.F. 1998. "The Formulation of Imperial Authority under Akbar and Jahangir.” In J.F.Richards ed. Kingship and Authority in South Asia. Delhi: Oxford University Press.

Riello, Giorgio, and Trithankar Roy, eds. 2009. How India Clothed the World: The World of South Asian Textiles, 1500-1850.Leiden: E.J. Brill.

Rizvi, Saiyd Athar Abbas. 1978. History of Sufism in India. Delhi: Munshiram Manoharlal, Publishers Pvt. Ltd.

Roseberry, J Royal. 1988. Imperial Rule in Punjab: 1818- 1881. Lahore: Vanguard.

Rose, H.A. 1911. A Glossary of the Tribes and Castes of the Punjab and North-West Frontier Province. Lahore: Superintendent, Government Printing.

Rosselli, John. 1974. Lord William Bentinck: The Making of a Liberal Imperialist: 1774-1839. Berkeley and Los Angeles: University of California Press.

Ross of Bladensburg, Sir John Foster George. 1900. Rulers of India: The Marques of Hastings, and the Final Overthrow of the Maratha Power. Oxford: Clarendon Press.

Sarkar, Jadunath. 1900. Nadir Shah in India [six Lectures Delivered in 1922, Compressed and Re-Arranged]. Patna: Patna University. 1916. History of Aurangzeb. Calcutta: M.C. Sarkar and Sons.

Schimmel, Annemarie. 1976. Pain and Grace: A Study of Two Mystical Writers of the Eighteenth-Century Muslim India. The Netherlands: E.J. Brill.

1980. Islam in the Indian Subcontinent. Leiden: E.J. Brill.

Shackle, C. 1993. "Styles and Themes in the Siraki Mystical Poetry of Sind." In Sindh Through the Centuries. Karachi: Oxford University Press.

Singh, Birinder Pal. 2012. “Criminal” Tribes of Punjab. New Delhi: Taylor \& Francis.

Singh, Khushwant. 1962. Ranjit Singh, Maharajah of the Punjab. London: George Allen \& Unwin Ltd.

Sinha, B. B. 1982. Society in Tribal India. New Delhi: B.R. Publishing Corporations. Skaria, Ajay. 2001. Hybrid Histories: Forests, Frontiers and Wildness in Western India. New York: Oxford University Press. 
Slamet- Velsink, Ina E. 1995. Emerging Hierarchies: Process of Stratification and Early State Formation in the Indonesioan Archipelago: Prehistory and the Ethnographic Present. Leiden: KITLV Press.

Smith, Wilfred Cantwell. 1998. "Lower- Class Uprisings in the Mughal Empire'." In The Mughal State: 1526-1750, edited by Muzaffar Alam and S Subrahmanyam. Delhi: Oxford University Press.

Sorely, H.T. 1966. Shah Abdul Latif of Bhit: His Poetry, Life and Times: A Study of Literary, Social and Economic Conditions in the Eighteenth Century Sind. Revised. London: Oxford University Press. http://www.goodreads.com/book/show/10145111shah-abdul-latif-of-bhit.

Spear, Percival, R. E. Frykenberg, and Narayani Gupta. 2002. The Delhi Omnibus. Delhi: Oxford University Press.

Srinivasachari, C.S. 1951. The Inwardness of British Annexation in India. Madras: University of Madras.

Subrahmanyam, S, and C. A. Bayly. 1988. "Portfolio Capitalist and the Political Economy of Early Modern India." Indian Economic and Social History Review, V. 25:401-24. no. 4.

Subramanian, Lakshmi. 1987. "Banias and the British: The Role of Indigenous Credit in the Process of Imperial Expansion in Western India in the Second Half of the Eighteenth Century." Modern Asian Studies 21 (3): 473-510.

Syed, Javed Haider. 2007. “The British Advent in Balochistan.” Pakistan Journal of History and Culture, Vol. XXVIII. No.2.

Talbot, Cynthia. 2001. Precolonial India in Practice: Society, Region, and Identity in Medieval Andhra.New York: Oxford University Press.

Talpur, Parveen. 2002. Talpur Rule in Sindh. Lahore: Ferozsons (Pvt) Limited.

Tate, G. P. 1911. The Kingdom of Afghanistan: A Historical Sketch.New Delhi: Asian Educational Services.

Temple, R.C. 1911. The Diaries of Streynsham Master, 1676-1680, and Other Contemporary Papers Relating Hithereto,. Vol. I, II. London: John Murray.

Thompson, Edward, and G. T. Garratt. 1999a. History of British Rule in India, Vol. 1. New Delhi: Atlantic Publishers \& Dist.

Titus, Murray T. 2005. Islam in India and Pakistan, a Religious History of Islam in India and Pakistan. New Delhi: Munshiram Manoharlal, Publishers Pvt. Ltd.

Trimingham, J. Spenser. 1998. The Sufi Orders in Islam. 2nd ed. New York: Oxford University Press.

Ward, A. W., and G.P. Gooch. 1923. The Cambridge History of British Foreign Policy; 1783-1919. London: Cambridge University Press.

Ward, J.R. 1994. "The Industrial Revolution and British Imperialism, 1750-1850."

The Economic History Review, New Series, XLVII: 44-65. 1.

Washbrook, David. 1988. "Progress and Problems: South Asian Economic and Social History c.1720-1860'." Modern Asian Studies, Vol. 22.1. 
Winius, George D., and Marcus P. M. Vink. 1994. The Merchant-Warrior Pacified: The VOC (The Dutch East India Company) and Its Changing Political Economy in India. Delhi: Oxford University Press.

Wink, André. 1986. Land and Sovereignty in India: Agrarian Society and Politics under the Eighteenth Century Maratha Swarajya. New York: Cambridge University Press.

Wong, J. Y. 1997. "British Annexation of Sind in 1843: An Economic Perspective." Modern Asian Studies 31 (2).

Yapp, M.E. 1962. 'Disturbances in Eastern Afghanistan, 1839-1842' Bulletin of the School of Oriental and African Studies, Vol. 25, No. 1/3, 288-313.

Yusuf, Mazhar. 1993. "The Dutch Trade in Sind in Historical Perspective." In The Dutch East India Company ( VOC) and Diewal-Sind ( Pakistan), in the 17th and 18th Centuries Based on Original Dutch Records, edited by Willem Floor, Karachi: Institute of Central \& West Asian Studies, University of Karachi.

Zaidi, Sunita. 1997. "Akbar's Annexation of Sind-An Interpretation." in Akbar and His India. Mumbai: Oxford University Press.

\section{Sindhi}

Lakho, Ghulam Muhammad, 2004. Kalhora Daure Hukumat.Karachi: Anjuman Ethad Ebasea.

\section{Urdu}

Faridi, Nur Ahmad Khan. 1984. Sindh ke Talpur hukmran: Talpur Balochon ke uruj o zaval ki ibratnak dastan. Multan: Siraeki Adabi Tahrik.

Mehar, Ghulam Rasool. 1958. Tarikh-i-Sindh. Vol. 1, 2. Karachi: Sindhi Adabi Board. 